\title{
Additional disclosure: triple-entry en momentum accounting : kwaliteitsverbetering van management accountingsystemen door het administreren van winstkrachten en winstsnelheden
}

Citation for published version (APA):

Blommaert, A. M. M. (1994). Additional disclosure: triple-entry en momentum accounting : kwaliteitsverbetering van management accountingsystemen door het administreren van winstkrachten en winstsnelheden. [Doctoral Thesis, Maastricht University]. Stenfert Kroese. https://doi.org/10.26481/dis.19941028ab

Document status and date:

Published: 01/01/1994

DOI:

10.26481/dis.19941028ab

Document Version:

Publisher's PDF, also known as Version of record

Please check the document version of this publication:

- A submitted manuscript is the version of the article upon submission and before peer-review. There can be important differences between the submitted version and the official published version of record. People interested in the research are advised to contact the author for the final version of the publication, or visit the $\mathrm{DOI}$ to the publisher's website.

- The final author version and the galley proof are versions of the publication after peer review.

- The final published version features the final layout of the paper including the volume, issue and page numbers.

Link to publication

\footnotetext{
General rights rights.

- You may freely distribute the URL identifying the publication in the public portal. please follow below link for the End User Agreement:

www.umlib.nl/taverne-license

Take down policy

If you believe that this document breaches copyright please contact us at:

repository@maastrichtuniversity.nl

providing details and we will investigate your claim.
}

Copyright and moral rights for the publications made accessible in the public portal are retained by the authors and/or other copyright owners and it is a condition of accessing publications that users recognise and abide by the legal requirements associated with these

- Users may download and print one copy of any publication from the public portal for the purpose of private study or research.

- You may not further distribute the material or use it for any profit-making activity or commercial gain

If the publication is distributed under the terms of Article $25 \mathrm{fa}$ of the Dutch Copyright Act, indicated by the "Taverne" license above,

Download date: 26 Apr. 2023 


\section{Stellingen bij het proefschrift}

\section{Additional disclosure: \\ triple-entry en momentum accounting}

kwaliteitsverbetering van management accountingsystemen

door het administreren van winstkrachten en winstsnelheden

door

AMM (Tjeu) Blommaert

1.

Dat we in het boekhouden nog steeds met debet en credit werken, is het onomstotelijk bewijs dat we de geschiedenis van dc accounting niet goed hebben begrepen.

2.

Het feit dat modellerings- en automatiseringsdeskundigen beweren dat het dubbel boekhouden ('double-entry bookkeeping') met de invoer van de administratieve automatisering is opgehouden te bestaan, doet vermoeden dat zij de toevoeging 'dubbel' onjuist hebben geïnterpreteerd (o.a. Thomsen, april 1994, EAA-congres Venetië).

Om dergelijke 'misverstanden' te voorkomen zou beter kunnen worden gesproken van tweedimensionaal commercieel boekhouden. De toevoeging 'commercieel' verwijst naar het eigen vermogen als centrale object van administratie. Van dit object worden in dit geval twee dimensies geadministreerd: 1) de structuur en 2) de omvang. Kennis van de structuur leidt (indirect) tot kennis van de omvang.

3.

De relevantie van bestaande financieel-administratieve systemen is verloren gegaan omdat deze zich te eenzijdig richten op de (juridische) gevolgen van transacties. Omzet, kosten en winst kunnen geen doel op zich zijn, maar vormen het resultaat van een aantal beheersbare en niét of minder goed beheersbare feiten. Door het administreren van de oorzaken achter deze feiten, zijnde de winstkrachten, kunnen accountingsystemen een belangrijk deel van de verloren relevantie herwinnen.

4.

Ondanks het feit dat de ontwikkeling van (differential) triple-entry accounting voor een belangrijk deel leunt op inzichten uit de natuurkunde, dient niet te worden vergeten dat de bedrijfseconomie een menswetenschap is en dus géén exacte wetenschap. De meest gangbare optimalisatie-principes zoals die in vele bedrijfseconomische studieboeken worden beschreven, zijn in het gunstigste geval slechts van toepassing op lagere diersoorten (Einhorn en Hogarth, 1981:1). 
5.

Door het hanteren van de instandhoudingseis en de integriteitseis ten aanzien van de derde dimensie in (differential) triple-entry accounting is, in tegenstelling tot wat men zou kunnen verwachten, het interpreteren van de aldus verkregen drie-dimensionale financiële gegevens vrij eenvoudig.

6.

Het komt in de praktijk nimmer voor dat een vierkantscontrole kan worden uitgevoerd. Gezien dit feit verdient het aanbeveling deze controle voortaan rechthoekscontrole te noemen.

7.

Het getuigt van weinig vakkennis en maatschappelijk inzicht wanneer wordt beweerd dat aan een opleiding welke niét opleidt tot boekhouder, het vak boekhouden ook niét tot het curriculum mag behoren.

8.

Het zal voor het accountantsberoep grote gevolgen hebben dat opleidingen voor registeraccountant zélf een voedingsbodem hebben gecreëerd voor opleidingen tot (register)controller door niet vroegtijdig in te spelen op de veranderde werkomgeving van de accountant.

9.

Tenzij werkeloosheid een op zich zelf staande doelstelling vormt, is uitvoer van het ambtelijke voornemen om het vak bedrijfseconomie voor HAVO en VWO af te schaffen omdat dit vak te sterk beroepsgericht en te weinig algemeen vormend zou zijn, een 'schoolvoorbeeld' van politiek mis-management.

10.

Het verwijt van mensen aan God dat $\mathrm{Hij}$ nicts doet aan oorlog en armoede is een contradictio. God heeft hen immers geschapen als medium voor het voorkomen en verhelpen daarvan.

11.

Zolang de mens langer moet werken dan hij vakantie heeft, zal hij meer moeten genieten van zijn werk dan van zijn vakantie. 



\section{Additional Disclosure}

Triple-entry en Momentum Accounting 


\section{Promotor:}

Prof. Dr. J.G. Kuijl RA

Beoordelingscommissie:

Prof. Dr. W. Buijink, voorzitter

Prof. H.L. Brink RA

Prof. Dr. T.L.C.M. Groot (Open Universiteit, Heerlen)

Prof. Dr. J. Klaassen RA (Vrije Universiteit, Amsterdam)

Prof. Dr. H. Schreuder 


\title{
ADDITIONAL DISCLOSURE:
}

\author{
TRIPLE-ENTRY \\ EN \\ Momentum ACCOUnTing \\ kwaliteitsverbetering van \\ management accountingsystemen \\ door het \\ administreren
}

van

winstkrachten en winstsnelheden

\section{PROEFSCHRIFT}

ter verkrijging van de graad van doctor aan de Rijksuniversiteit Limburg te Maastricht, op gezag van de Rector Magnificus, Prof. Dr. H. Philipsen, volgens het besluit van het College van Dekanen, in het openbaar te verdedigen op 28 oktober 1994 om 16.00 uur

door

Arnoldus Mathias Marie Blommaert 


\section{CIP-GEGEVENS: KONINKLIJKE BIBLIOTHEEK, DEN HAAG}

ISBN 9020724827

\section{(C) Educatieve Partners Nederland, Houten, 1994}

Alle rechten voorbehouden. Niets uit deze uitgave mag worden verveclvoudigd, opgeslagen in een geautomatiseerd gegevensbestand, of openbaar gemaakt, in enige vorm of op enige wijze, hetzij elektronisch, mechanisch, door fotokopieèn, opnamen, of enige andere manier, zonder voorafgaande schriftelijke toestemming van de uitgever.

Voor zover het maken van kopieèn uit deze uitgave is toegestaan op grond van artikel 16B Auteurswct $1912 \mathrm{j}^{\circ}$ het Besluit van 20 juni 1974, St.b. 351, zoals gewijzigd bij het Besluit van 23 augustus 1985. St.b. 471 en artikel 17 Auteurswet 1912, dient men de daarvoor wettelijk verschuldigde vergoedingen te voldoen aan de Stichting Reprorecht (Postbus 882, 1180 AW Amstelveen). Voor het overnemen van gedeelte(n) uit deze uitgave in bloemlezingen, readers en andere compilatiewerken (artikel 16 Auteurswet 1912) dient men zich tot de uitgever te wenden. 


\section{Voorwoord}

Het schrijven van deze dissertatie is een geheel andere bezigheid gebleken dan het schrijven van een leerboek waarvan ik vele projecten reeds had doorlopen (bij leerboeken was het zo dat alles wat ik opschreef, terstond werd gedrukt). In dit verband ben ik mijn promotor Prof. Dr. J.G. Kuijl RA bijzondere dank verschuldigd. De wijze waarop hij mijn leerproces heeft begeleid en zijn inspirerende wijze van coaching waren voor mij de noodzakelijke ingrediënten om dit project tot een goed einde te brengen.

Mijn collega's van de Economische Faculteit van de Rijksuniversiteit Limburg hebben mij bij voortduring gestimuleerd tot dit onderzoek. In het bijzonder Bram Beek, Laury Bollen, Willem Buijink, Tom Groot en mijn broer Jos Blommaert ben ik in dit verband zeer erkentelijk.

Ook het enthousiasme van een groot aantal economie-studenten heeft mij gemotiveerd op de ingeslagen weg door te gaan. In het bijzonder dank ik hiervoor John Eijkelberg, Geert Ewalts en Eric Olders.

Prof. H. Brink RA en Prof. Dr. L. Traas ben ik dank verschuldigd voor de mogelijkheden welke zij hebben geboden bij het uitvoeren van het gebruikers-experiment (zie hoofdstuk 9). Tevens bedank ik de leden van de beoordelingscommissie voor hun opbouwende commentaar op een eerdere versie van dit proefschrift.

Tot slot dank ik allen met wie ik ooit een schrijfproject heb mogen afleggen en dank ik alle uitgevers voor het in mij gestelde vertrouwen. De vele in deze projecten opgedane ervaringen zullen ergens in dit proefschrift hun weerslag hebben gevonden. Een extra woord van dank richt ik aan Harry Schram, uitgever bij Educatieve Partners Nederland te Houten voor zijn professionele begeleiding bij de produktie van dit proefschrift alsmede aan de Vereniging van leraren in de economisch/maatschappelijke vakken (VECON) voor haar financiële support bij het uitbrengen van een handelseditie van dit proefschrift.

Een proefschrift schrijven doe je niet alleen.

Tegen mijn echtgenote Yvonne kan ik nu zeggen: 'We hebben het gered'.

Sittard, mei 1994 



\section{Inhoud}

Voorwoord

1 Verantwoording 1

1.1 Inleiding 1

1.2 Onderzoekhypothesen $\quad 6$

1.3 Accounting en ontwikkelingen in andere wetenschappen $\quad 8$

$\begin{array}{lll}1.4 & \text { Samenvatting } & 10\end{array}$

2 Management accounting: verkenning van een vakgebied 11

$\begin{array}{lll}2.1 & \text { Inleiding } & 11\end{array}$

2.2 Het management accountingsysteem als een gespecialiseerd $\begin{array}{ll}\text { informatiesysteem } & 12\end{array}$

2.3 Management accounting en management control 14

2.4 Verschillende benaderingen van accounting; positionering van het triple-entry en momentum accountingonderzoek 18

2.4.1 Het agencyparadigma 23

2.4.2 Agencyparadigma en het triple-entry en momentum $\begin{array}{ll}\text { accountingonderzoek } & 27\end{array}$

$2.5 \quad$ Samenvatting $\quad 32$

3 Hoofdlijnen van de geschiedenis van (management) accounting 33

$3.1 \quad$ Inleiding 33

3.2 Hoofdlijnen van de geschiedenis van het boekhouden 34

3.2.1 Periode van het enkel boekhouden 34

3.2.2 Periode van het dubbel boekhouden; ontwikkelingen in Italië 36

3.2.3 De ontwikkeling van het dubbel boekhouden $\begin{array}{ll}\text { in andere landen } & 39\end{array}$

3.2.4 Alternatieve interpretatie van de ontwikkeling van het dubbel boekhouden $\quad 41$

3.2.5 Economische ontwikkeling en boekhouden 42

3.3 Van boekhouden naar cost accounting 44

$3.4 \quad$ Van cost accounting naar management accounting 48

$3.5 \quad$ Samenvatting $\quad 52$ 
4 'State of the art' en toekomstverwachtingen ten aanzien van de management accounting

$\begin{array}{lll}4.1 & \text { Inleiding } & 57\end{array}$

4.2 Waarom falen management accountingsystemen? $\quad 60$

$\begin{array}{lll}4.3 & \text { Behavioral accounting } & 65\end{array}$

4.4 Enkele nieuwe ontwikkelingen in de management accounting 67

4.5 Enkele toekomstverwachtingen met betrekking tot de $\begin{array}{ll}\text { management accounting } & 70\end{array}$

4.6 Samenvatting

5 Gegevenskenmerken, conceptual framework en management accounting

$5.1 \quad$ Inleiding

$5.2 \quad$ Relevante gegevenskenmerken

5.3 Het conceptual framework voor de financial accounting

5.4 Conceptual framework en de structuur van het ontwerp van een management accountingsysteem

5.5 Accounting measurement

5.6 Samenvattig

6 Gegevensperceptie en financiële functie $\quad 99$
6.1 Inleiding

6.2 Populaties, steekproef, response en statistische verwerking van de gegevens

6.3 Enquête-resultaten; profielschets van de respondenten: accountants en controllers

$6.4 \quad$ Hypothese-testing

6.5 Overige enquêteresultaten

6.6 Samenvatting

7 Winstkrachten en de ontwikkeling van de winstcapaciteit van het eigen vermogen

7.1 Inleiding; dimensieanalyse in de accounting

7.2 Zoektocht naar de derde dimensie: een eerste verkenning

7.3 De twee dimensies in het dubbel boekhouden 
$\begin{array}{lll}7.4 & \text { Temporal triple-entry accounting } & 129\end{array}$

7.4.1 De dimensies in temporal triple-entry accounting 129

7.4.2 De verwerking van gegevens in een temporal triple-entry accountingsysteem

$\begin{array}{ll}\text { 7.4.3 Het budget, een derde dimensie? } & 137\end{array}$

7.4.4 Temporal triple-entry accounting en budgettering 139

$\begin{array}{ll}7.5 & \text { Differential triple-entry en momentum accounting } \\ & 140\end{array}$

7.5.1 De dimensies in differential triple-entry accounting 140

7.5.2 Beschrijving van beweging en kracht in de natuurkunde en de implicaties voor de accounting; Inleiding

7.5.3 Enkele hoofdlijnen van de ontwikkelingen in de klassieke mechanica

7.5.4 Wealth accounting, momentum accounting en force accounting

$\begin{array}{ll}\text { 7.5.5 Postulaten bij momentum accounting } & 159\end{array}$

$\begin{array}{ll}\text { 7.5.6 Winstkrachten nader bezien } & 162\end{array}$

7.6 Winstkrachten en financieel-economische berichtgeving 165

$\begin{array}{lll}7.7 & \text { Samenvatting } & 169\end{array}$

8 Operationalisering van het concept van triple-entry en momentum accounting 171

$\begin{array}{lll}8.1 & \text { Inleiding } & 171\end{array}$

$\begin{array}{ll}8.2 \text { De CLM-case } & 172\end{array}$

8.3 Gegevensverwerking bij CLM in een dubbel boekhoudmodel 174

8.4 Gegevensverwerking in een drie-dimensionaal accountingmodel $\quad 181$

$\begin{array}{ll}\text { 8.4.1 Inleiding } & 182\end{array}$

8.4.2 Intracomptabele verwerking van de derde dimensie en de samenstelling van de winst-mutatiestaat

8.4.3 Financieel jaarverslag van CLM bij toepassing van differential triple-entry en momentum accounting

8.5 Het journaal en grootboek bij differential triple-entry en momentum accounting nader bezien

8.6 Differential triple-entry accounting ten opzichte van matrix-accounting respectievelijk relationeel accounting

8.7 Differential triple-entry accounting, accountingmodellen en de 'events approach'

8.8 Samenvatting 
9 Beslissingsrelevantie van triple-entry en momentum accounting; verslag van een experiment

9.1 Inleiding; typering van het experiment

9.2 Profielschets van de experiment-deelnemers

9.3 Opzet van het experiment

9.4 Onderzoeksresultaten

9.5 Suggesties voor vervolgonderzoek

9.6 Samenvatting

Lijst van begrippen

Bijlage bij hoofdstuk 6

Integrale tekst van de enquête

Bijlage bij hoofdstuk 7

Lijst van bedrijven waarvan de toekomstverwachtingen (zoals

opgenomen in het jaarverslag) zijn geanalyseerd

Bijlagen bij hoofdstuk 9

Case gebaseerd op het conventionele accountingsysteem

(groep D)

Case gebaseerd op het driedimensionale accountingsysteem (groep T)

Vooraf aan groep $T$ verstrekte informatie

Vragenlijst voor groep $D$

Vragenlijst voor groep T

Lijst van geraadpleegde literatuur

Curricculum vitae

Over Ijiri

Summary and conclusions

Personenregister 


\section{Verantwoording}

"Ijiri's triple-entry bookkeeping is intended as a serious contribution to the theory of accounting and on which has particular relevance to management accountants. Whether or not it achieves wider recognition and implementation seems doubtful at present but it is worthy of serious study" (Parkinson, 1987:22).

\subsection{Inleiding}

De relevantie en realiteitswaarde en daarmee de kwaliteit van vigerende (management) accountingsystemen worden tegenwoordig vaak als 'niét-toereikend' bestempeld (zie onder andere Kaplan, 1984:95; Brimson, 1986:25; Goldratt en Fox, 1991:34; Mednick, 1992:554). Diverse belanghebbende partijen zoals praktizerende accountants/controllers en wetenschappers zoeken naar oplossingen voor de gestelde problemen. Als bijdragen aan mogelijke oplossingen kunnen worden genoemd ontwikkelingen als "activity based costing' en 'strategic cost accounting'. Maar in zekere zin is hier sprake van specialistische oplossingen ${ }^{1}$.

Het vinden van een goede oplossing ligt voor een belangrijk deel in het adequaat onderkennen van de probleemsituatie. Bij het onderhavige onderzoek naar de mogelijkheid van het toepassen van triple-entry en momentum accounting ten behoeve van het verbeteren van de kwaliteit van management accountingsystemen, is gezocht naar oorzaken van de gestelde problemen en minder naar (symptomatische en daarmee per definitie 'lokale') oplossingen. De in het vervolg plausibel te maken veronderstelling is dat bedoelde problemen grotendeels hun oorzaak vinden aan de basis van het klassieke accountingmodel. Dit model poogt een complexe bedrijfswerkelijkheid weer te geven door het administreren van slechts twee dimensies van het eigen vermogen van een onderneming. Dere dimensies betreffen:

- de samenstelling van het eigen vermogen (zoals weergegeven door een balans) ${ }^{2}$, en - de ontwikkelingen in de omvang van het eigen vermogen (zoals weergegeven door een resultatenrekening) ${ }^{3}$.

\footnotetext{
${ }^{1}$ Specialistische oplossingen staan tegenover een holistische benadering (systeembenadering) waarbij centraal staan de interacties van de bij een systeem te onderscheiden onderdelen en de invloed hiervan op het functioneren van het totaal.

${ }^{2}$ Wannecr een balans de samenstellende delen van het eigen vermogen van een onderneming weergeef toont dit ovcrzicht tegclijkertijd de omvang van het eigen vermogen per balans-datum (dit is wat men zou kunnen noemen het 'pars pro toto'-element in de 'kunst' van het bockhouden). De omvang van het eigen vermogen volgt per sahlo uit de geadministreerde samenstellende delen, dit zijn de activa en de schulden (waaronder voorzieningen).

${ }^{3}$ Voor een sluitende afstemming dient het saldo van de resultatenrekening te worden aangevuld met het netto-effect van vermogenstransacties (zoals een emissie van aandelen en herwaardering van activa). Vermogenstransacties, worden hier evenwel niel in de beschouwing betrokken.
} 
Kort gezegd: samenstelling en omvang zijn de dimensies van het eigen vermogen welke in een klassiek (dubbel) boekhoudmodel worden geadministreerd.

De 'rode draad' van dit onderzoek is het (te valideren) uitgangspunt dat een belangrijk deel van de gesignaleerde kwaliteitsproblemen met betrekking tot management accountingsystemen kan worden opgelost door aanpassing van het klassieke boekhoudmodel.

Bij toepassing van (differential) triple-entry accounting wordt analoog aan de ideeën van Ijiri $(1975,1982,1986,1989)$ aan de genoemde twee dimensies een derde dimensie toegevoegd: ontwikkelingen in de ontwikkeling van de omvang van het eigen vermogen. Hierbij gaat het om oorzaken van mutaties in resultaatposten. Dergelijke oorzaken kunnen winstkrachten worden genoemd. Voorbeelden van winstkrachten zijn het in de markt komen van een nieuwe concurrent, veranderde algemeen en specifiek (sectorgebonden) economische omstandigheden, het voeren van een advertentiecampagne, nieuwe investeringen, de overheid die een bepaald belastingregime wijzigt of subsidieregelingen aanpast, een (materiële) valutakoerswijziging, het maken van een loonafspraak met de vakbonden en een bericht van rentewijziging door de bank.

Door de samenstellende delen van het eigen vermogen (de eerste dimensie) te administreren per een bepaald tijdstip, kan de mutatie worden vastgesteld die in enige verslagperiode is opgetreden in de omvang van het eigen vermogen. In de tweede dimensie wordt voor deze mutatie een verklaring gegeven middels posten op de resultatenrekening. In de derde dimensie wordt een verklaring gegeven voor de mutatie in de omvang van het resultaat over enige verslagperiode ten opzichte van het resultaat over een vorige verslagperiode (het gaat hierbij derhalve om ontwikkelingen in resultaatposten).

Bedoelde 'verklaring' bestaat uit het beschrijven van de geldelijke effecten van de in de betreffende periode gerealiseerde winstkrachten. Het systematisch overzicht waarop deze effecten worden getoond, kan 'winst-mutatiestaat' of 'overzicht van winstkrachten' ('action statement') worden genoemd. Winstkrachten zijn feiten waardoor de winstcapaciteit van het eigen vermogen van de onderneming verandert. Anders gezegd: winstkrachten beïnvloeden het realiseerbare bedrijfsresultaat. Op termijn leidt dit tot mutaties in het gerealiseerde bedrijfsresultaat. Met een aan de primaire overzichten ${ }^{4}$ gerelateerde overzicht ${ }^{5}$ van winstkrachten wordt aan de gedachte vorm gegeven dat winst

\footnotetext{
${ }^{4}$ Dit zijn de balans, de resultatenrekening en de toelichting daarop, eventueel aangevuld met een staat van herkomst en besieding van (liquide) middelen.

5 Deze overzichten zijn onderling gerelateerd omdat ze verschillende aspecten (dimensies) van de zelfde financiële transacties en/of gebeurtenissen beschrijven.
} 
geen doel op zich kan zijn, maar het logische bijprodukt is van een aantal goed uitgevoerde zaken ${ }^{6}$. Peters en Watcrman merken in dit verband op:

"The idea that profit is a natural byproduct of doing something well, not an end in itself, is also almost universial" (Peters en Waterman, 1982:284).

Op basis van een administratie van winstkrachten (ook te noemen: 'winstaandriften' of 'profit-drivers') kan de winst-mutatiestaat direct aan het administratieve systeem worden ontleend. Bij winstkrachten kan in eerste instantie worden gedacht aan de voor een bedrijf onderscheiden kritieke (financieel) succesfactoren ${ }^{7}$. Hierbij moge het voor zich spreken dat, wanneer inzake de winstkrachten een onjuiste dan wel onvolledige selectie is gemaakt, er op de winst-mutatiestaat een materiële post 'onverklaard' (of 'niet toegerekend') kan resteren.

In figuur 1.1 is de relatie tussen de genoemde drie dimensies afgebeeld. De figuur geeft weer dat de derde dimensie logisch volgt uit de bestaande twee dimensies.

In een differential triple-entry wealth accountingsysteem worden de financiële gevolgen van opgetreden winstkrachten stelselmatig opgetekend. Deze winstkrachten beïnvloeden de winstcapaciteit van het eigen vermogen van de onderneming. Bij afwezigheid van ontwikkelingen in winstkrachten is het bedrijfsresultaat ceteris paribus van periode tot periode gelijk. De toevoeging 'differential' geeft aan dat het triple-entry accountingsysteem zich in de derde dimensie richt op de administratie van winstdifferenties of winstmutaties. De toevoeging 'wealth' geeft aan dat in dit systecm de administratie van het eigen vermogen centraal staat, zoals ook het geval is in het alom bekende enkelvoudige en dubbel boekhouden.

Winstcapaciteit hangt nauw samen met de 'earning power' van de onderneming (ook wel aangeduid als 'rendementswaarde'). 'Earning power' kan worden gedefinieerd als de mate waarin de onderneming met het beschikbare eigen vermogen in de toekomst netto ontvangsten kan genereren. De 'earning power' is de contante waarde van deze toekomstige netto ontvangsten. Het verschil tussen winstcapaciteit van het eigen vermogen en 'earning power' is met name dat de winstcapaciteit wordt bepaald op basis

\footnotetext{
${ }^{6}$ Feitelijk raakt dit punt de operationaliteit van winst als doelstelling.

${ }^{7}$ Deze factoren worden vaak aangeduid als kritische factoren (zie bijvoorbeeld Hartog at al, 1992:56,57). Mijns inziens berust dit op een onjuiste interpretatie van het Engelse 'critical'. Omdat het (financieel) succes van een bedrijf met name wordt afgemeten aan de hoogte van het gerealiseerde resultaat, kan in dit verband ook van 'kritieke winstfactoren' of 'kritieke winstkrachten' worden gesproken. Overigens zij hierbij opgemerkt dat kritieke succesfactoren meestal worden opgevat als factoren die bepalend zijn voor het al dan niet welslagen van de ondernemingsstrategie. Aangezien winst een korte-termijn begrip is, kunnen uit dien hoofde de nodige verschillen be(ont)staan tussen kritieke succesfactoren en winstkrachten.
} 
van gerealiseerde winstkrachten. Bij de beoordeling van de 'earning power' worden ook de financiële effecten van winstkrachten meegenomen welke zich naar verwachting in de toekomst zullen manifesteren. Bij 'earning power' spelen derhalve nadrukkelijk ook ongerealiseerde winstkrachten een rol. In die zin is de 'earning power' een meer speculatieve waarde dan de winstcapaciteit van het eigen vermogen van de onderneming.

Figuur 1.1 De drie dimensies in een triple-entry accountingsysteem.

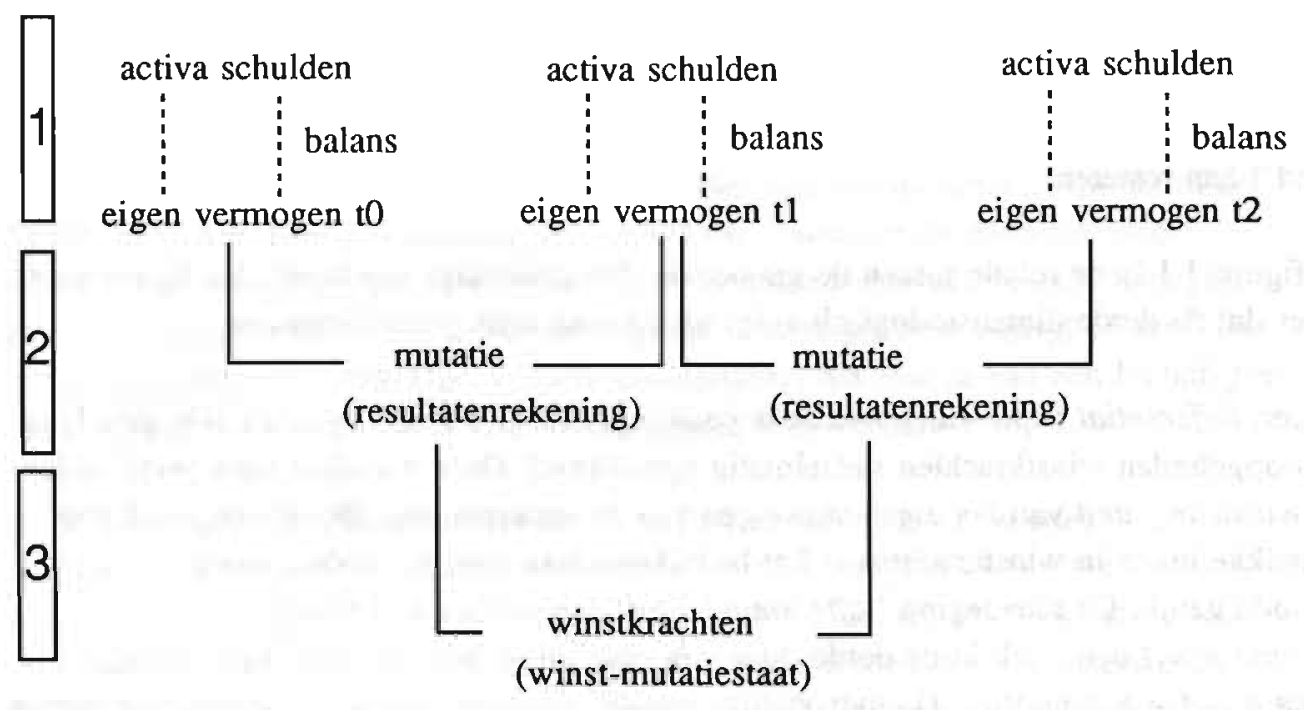

Winstcapaciteit wordt gewoonlijk gemeten als een resultaat per maand of enig ander tijdvak. Dit kan worden aangeduid als de winstsnelheid of 'income momentum'. De uitdrukking 'per' impliceert hier dat het gaat om een potentieel aan resultaat ${ }^{8}$. Het administratieve systeem dat de ontwikkelingen in de winstsnelheid vastlegt, noemt ljiri momentum accounting (1989:45). Winstsnelheid is een voorraadgrootheid ${ }^{9}$. Het is de per een bepaald moment gemeten winstcapaciteit, uitgedrukt in guldens per periode (in tripleentry accounting is de geldeenheid uitgedrukt in guldens). Het systematisch overzicht waarop de winstsnelheid van enig moment wordt getoond, kan 'winstsnelheids-staat'

\footnotetext{
8 Vergelijk dit met een auto die $120 \mathrm{~km}$ per uur rijdt. Na elk uur rijden is de afgelegde afstand in principe $120 \mathrm{~km}$. Overigens heeft de uitdrukking 'per' in de bedrijfsadministratie nog een andere betekenis. Het is dan het tijdstip waamaar alle gegevens worden herleid. Wanneer de balans wordt opgemaakt per 31 december, kan het inventariseren en waarderen bijvoorbecld geschieden op 10 januari daaraanvolgend. Alle gegevens echter worden herleid tot bedragen per 31 december.

9 'Winst' daarentegen is een stroomgrootheid.
} 
('momentum statement') worden genoemd. Het systematisch overzicht waarmee een verklaring wordt gegeven voor de mutatie in de winstsnelheid van het eigen vermogen, kan dan als 'winstsnelheids-mutatiestaat' ('impulse statement') worden aangeduid. Winstsnelheids-staat en winstsnelheids-mutatiestaat zijn de centrale overzichten in momentum accounting.

Mutaties in winstkrachten verklaren behalve de periodieke ontwikkeling in het bedrijfsresultaat ook de verandering die in de winstsnelheid is opgetreden. Deze 'verandering' kan zowel een versnelling als een vertraging betreffen. Via een administratie van winstkrachten kunnen derhalve gegevens ter beschikking worden gesteld over de ontwikkeling in de winstcapaciteit van het eigen vermogen van de onderneming welke zich in een bepaalde periode per saldo heeft gemanifesteerd. Voorts kan een sluitende verklaring worden gegeven voor de ontwikkeling in het van periode tot periode gerealiseerde resultaat.

In figuur 1.2 is de relatie tussen triple-entry accounting en momentum accounting zoals die in het voorgaande is uiteengezet, schematisch weergegeven.

Men zou kunnen verwachten dat met het beschikbaar stellen van gegevens over winstkrachten casu quo winstsnelheden de relevantie en/of realiteitswaarde en daarmee de bruikbaarheid van accountinggegevens aanzienlijk verbetert, doordat de 'predictive value' toeneemt ${ }^{10,11}$. Deze toegevoegde waarde moet de extra administratieve kosten rechtvaardigen.

${ }^{10}$ Het Accounting Standards Committce (ASC) heeft bij het voorstel van een 'conceptual framework' voor de financial accounting deze relatie tussen het aspect waarover wordt geïnformeerd en de bruikbaarheid van de aldus verstrekte gegevens vastgelegd in een aparte paragraaf (paragraaf 40, 'choice of aspect', Accountancy, 1991).

11 Men kan stellen dat door toepassing van triple-entry accounting het onderscheid tussen het 'accounting concept of profit' en het 'economic concept of profit' zoals dat door accountants respectievelijk algemeen economen en in de financieringsleer wordt toegepast, (verder) wordt verkleind. 
Figuur 1.2 De relatie tussen triple-entry en momentum accounting.

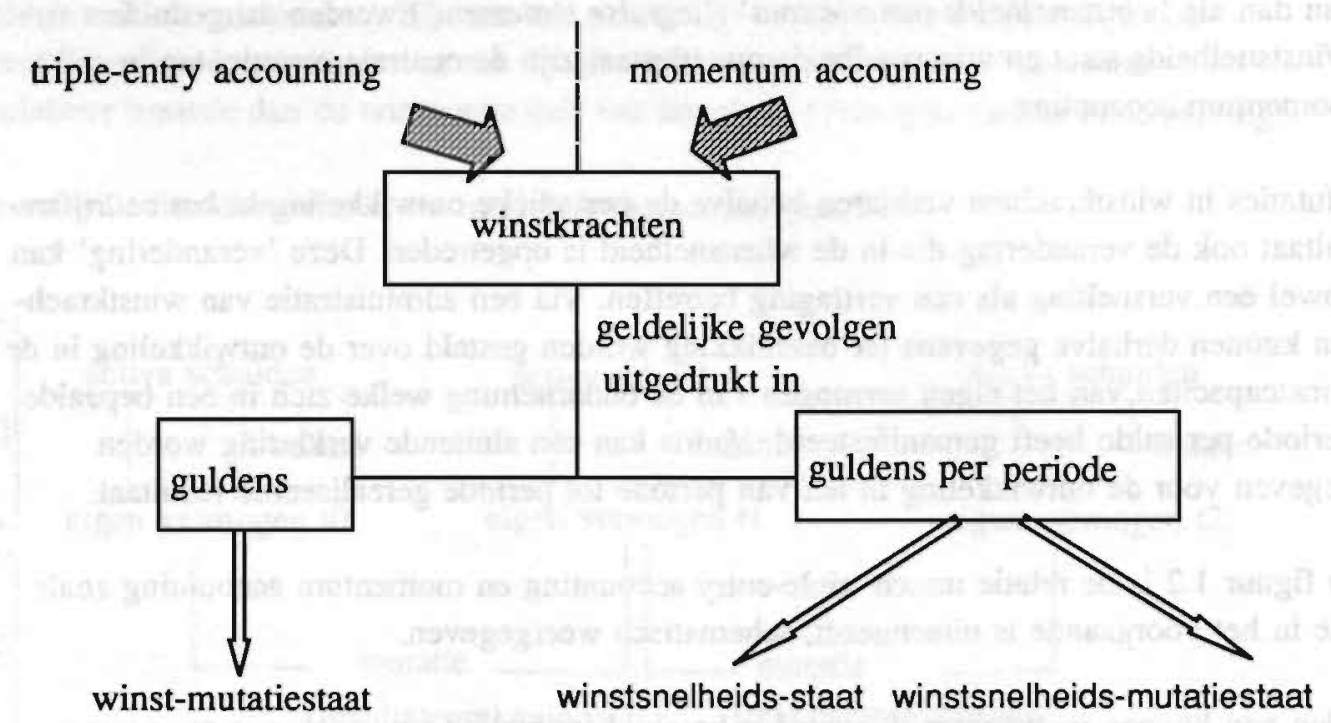

Conventionele twee-dimensionale accountingsystemen zijn vrij eenzijdig gericht op het administreren van cash flows uit hoofde van in het verleden gecreëerde winstkrachten. Dit betekent doorgaans dat wat als resultaat in periode $t_{1}$ wordt gerapporteerd, betrekking heeft op in periode $t_{0}$ en in daaraan voorafgaande perioden (wellicht door andere managers) ondernomen activiteiten. Een drie-dimensionaal accountingsysteem doet tevens verslag over het in de verslagperiode ontstaan casu quo teniet gaan van winstkrachten en, zoals in momentum accounting, de gevolgen hiervan voor de winst-snelheid ${ }^{12}$.

\subsection{Onderzoekhypothesen}

Zoals gezegd leidt triple-entry accounting tot een uitbreiding van het bestaande administratieve systeem - er wordt immers een dimensie toegevoegd - en dit brengt extra kosten

\footnotetext{
${ }^{12}$ Traditionele accountingsystemen kunnen worden vergeleken met de werking van een kilometerteller in een auto. Dergelijke systemen meten de 'afgelegde afstand' (het resultaat) ten opzichte van een bepaalde uitgangssituatie. Hierbij is de (implicicte) veronderstelling dat er geen snelheidsveranderingen optreden (de snelheidsmeter beweegt niet). In een triple-entry accountingsysteem wordt deze veronderstelling losgelaten en worden de ooraken geudministreerd ten gevolge waarvan de snelheidsmeter beweegt (dit zijn de winstkrachten). Vervolgens wordt op sluitende wijze de interactic tussen veranderingen in snelheid en de 'afgelegde afstand' (het resultaat) bepaald. Net zoals de 'afgelegde afstand' de realisatie is van de gemiddelde snelheid van de auto, is het bedrijfsresultaat te beschouwen als de realisatie van cen bepaalde winstsnelheid.
} 
met zich mee. In dit verband is het gewenst bepaalde verwachtingen te kwantificeren inzake potentiële voordelen van een dergelijk systeem, zodat een goede kosten-batenanalyse kan plaatsvinden. Zowel ten behoeve van de kwaliteit van te nemen beslissingen als in het kader van de verantwoording die daarover aan derden moet worden afgelegd, kan triple-entry en momentum accounting belangrijke voordelen bieden.

Gezien het voorgaande staan in dit onderzoek de volgende hypothesen centraal:

\section{Hypothese 1}

Het 'conceptual framework' voor de financial accounting is voor wat betreft de hierin onderscheiden gegevenskenmerken tevens bruikbaar voor de management accounting, met dien verstande dat in de management accounting ten aanzien van deze gegevenskenmerken significant andere belangrijkheidscoëfficiënten gelden.

\section{Hypothese 2}

In vergelijking met een conventioneel ('double-entry') accountingsysteem neemt bij toepassing van triple-entry en momentum accounting de kwaliteit van op deze gegevens gebaseerde beslissingen (voorspellingen) significant toe.

\section{Hypothese 3}

In vergelijking met een conventioneel ('double-entry') accountingsysteem gedraagt een agent zich bij toepassing van triple-entry accounting in de ogen van de principaal significant meer verantwoord.

Omdat het onderzoek naar de betekenis van triple-entry en momentum accounting vrij fundamenteel van aard is, is voor het toetsen van de hypothesen 2 en 3 gekozen voor een laboratorium-experiment (zie hoofdstuk 9 voor een beschrijving van dit experiment en de resultaten). Het met behulp van een case uitgevoerde experiment beschrijft hoe een aantal proefpersonen reageert op de verstrekte gegevens aangaande de winstsnelheid en zijn 'economische aanjagers'. De eerste hypothese is getest met behulp van een (schriftelijke) enquête (zie voor de resultaten hiervan hoofdstuk 6).

Abdel-Khalik en Ajinkya (1979:13) structureren de ontwikkelingen van accountingonderzoek in een aantal fasen. In de eerste fase is het onderzoek vooral gericht op de vastleggingsactiviteit. Het gaat hierbij om zaken als administratieve procedures, meeteenheden en realisatie-aspecten. In de volgende fase richt het accountingonderzoek zich met name op de verslaglegging. Wie zijn de beoogde gebruikers? Welke gegevens dienen te worden verstrekt, in welk detail en met welke frequentie? Enzovoort. Het huidige accountingonderzoek richt zich in hoofdzaak op de interactie tussen verslaglegging en gebruikers ('information inductance'). Onder andere de beoordeling van de verslaggeving door 
de controlerend accountant en mogelijke reacties van de kapitaalmarkt staan in dit onderzoek centraal (Knoops, 1993:31). Het triple-entry en momentum accountingonderzock oriënteert zich wat dit betreft op de vastleggingsactiviteit.

\subsection{Accounting en ontwikkelingen in andere wetenschappen}

De speurtocht naar het bestaan van een derde dimensie ten aanzien van de financiële administratie van transacties heeft een in wezen filosofische achtergrond. In menige religie en in metafysische systemen en filosofieën van de wereld vinden we dit aspect van 'drievoud' terug, zoals bijvoorbeeld in de Christelijke Drievuldigheid Gods (Vader, Zoon en Heilige Geest), de drie 'Guna's' van het hindoeïsme (Brahma-Vishnu-Shiva) of Yin en Yang en $\mathrm{Qi}^{13}\left(\mathrm{Qi}=\right.$ Yin+Yang) in de Chinese filosofie ${ }^{14}$. In zoverre is het onderhavige onderzoek naar triple-entry en momentum accounting dan ook min of meer een 'geestelijk avontuur' te noemen ${ }^{15}$. Maar de drievoudigheid 'verleden-heden-toekomst' speelt in de accounting al van oudsher een belangrijke rol.

Elke manifestatie die zich voordoet, resulteert in polariteit of dualiteit, dat wil zeggen: onderlinge verbondenheid (of eenheid) van tegenstellingen (Rendel, 1989:12). Deze dualiteit (dichotomy) is tevens het fundament van dubbel boekhouden (zie bijvoorbeeld Ijiri, 1982:2 en Anthony en Reece, 1983:32). Onder andere in het balansevenwicht en in het journaal manifesteert zich deze dualiteit. Steeds bestaan er twee polen: debet en credit, activa en passiva of lichaam en geest, geluk en ongeluk, verleden en toekomst, en Yin en Yang. Zonder polariteiten kan geen enkel compleet systeem van de metafysica of de wetenschap van het leven bestaan. Geen enkele ervaring is van betekenis wanneer deze niet tussen twee polen van mogelijkheden kan plaatsvinden.

Het verband tussen de twee polen is het derde aspect van het drievoud. Deze relationele benadering staat ook centraal in de bootstrap-filosofie van de natuurkundige Chew die

\footnotetext{
${ }^{13}$ Volgens de Chinese benadering bevat elke manifestatie een drie-eenheid. Probeer maar eens een bal in hel zonlicht te leggen. Tegelijkertijd wordt (een deel van) de bal dan in de schaduw gelegd en in een soort overgangsgebied van schaduw naar zon.

${ }^{14}$ Alhoewel volgens bijvoorbeeld de dieptepsychologen Freud en Jung en de natuurkundige Pauli een dimensic ontbreekt in de triniteit van het Christendom. Deze verborgen dimensic betreft het onbewuste. Het getal dat staat voor volledigheid en heelheid is volgens hen dan ook 4 . In de natuurkunde staat het getal 4 (via sinussen en cosinussen) voor een eenheidscirkel ('mandala') in een complex vlak.

${ }^{15}$ Overigens is het uitgangspunt van accounting en de economische wetenschap in het algemeen (het schaarstebeginsel) maar weinig spiritueel. Uitgegaan wordt van het feit dat mensen streven naar de bevrediging van een veelheid naar intensiteit gerangschikte behoeften. Hiertoe staan beperkte en altematief aanwendbare middelen ter beschikking. Maar bijvoorbeeld in het Christendom en in het Zen-Boedisme gaat men er van uit dat datgene wat men zoekt, niet kan worden gevonden. Pas wanneer het bewuste streven wordt losgelaten, kan het worden gerealiseerd.
} 
stelt dat dingen enkel bestaan bij de gratie van hun wederzijdse samenhang (Capra. $1988: 46)^{16}$.

Activiteiten, zoals transacties, veroorzaken polariteiten (dualiteit). En onvermijdelijk en onontkoombaar manifesteert zich drievoud in elke activiteit die plaatsvindt ${ }^{17}$. Dit is met name van belang voor de accounting waarbinnen immers de financieel-economische gevolgen van bedrijfs-activiteiten (transacties) worden geadministreerd. Derhalve is behalve een beschrijving van (1) omvang en (2) samenstelling van het eigen vermogen ook een beschrijving wenselijk van (3) de relatie tussen deze twee polariteiten.

Wanneer, zoals in vele filosofieën en bijvoorbeeld in de natuurkunde en moderne geneeskunde, nadrukkelijk rekening wordt gehouden met het beschrijven van drie aspecten van alle dingen die zich aan ons voordoen, kan men zich afvragen waarom dit niet ook gebeurt in de accounting en met name in de bedrijfsadministratie. Want ook bedrijven bevinden zich bij voortduring in het spanningsveld van twee polariteiten verlies en winst - en streven naar een evenwichtige positie daarbinnen. Wanneer in de tijd de positie tussen de twee polen verandert, is het met name met het oog op het beheersen van de toekomst van belang te analyseren waardoor die positie is gewijzigd. Hiertoe wordt een verschillenanalyse uitgevoerd die feitelijk betrekking heeft op het derde aspect van het drievoud: Wat zijn de oorzakelijke relaties van de beweging in de financiële positie $^{18}$ ?

Het is in hoofdzaak de administratief geintegreerde en dus intracomptabele verwerking van een continu en stelselmatig uitgevoerde totale verschillenanalyse waarmee triple-entry accounting zich bezighoudt. Hierbij wordt het 'heden' gezien als de verbindende schakel (de relatie) tussen de polariteiten 'verleden' en 'toekomst' en ontstaat er een 'trichotomy' (Ijiri, 1982:11). De veronderstelling is hierbij dat het resultaat zoals dat in het verleden is gerealiseerd, ook in de toekomst kan worden gegenereerd. Wanneer (in het heden) blijkt dat dit in meerdere of mindere mate mogelijk is en derhalve de kracht om resultaat op te wekken wijzigt, worden het bedrag dat hiermee is gemoeid alsmede de achterliggende oorzaak intracomptabel geadministreerd. De verwachting is dat hiermee de voorspellende waarde van de gegevens die aan het accountingsysteem kunnen worden ontleend,

\footnotetext{
${ }^{16}$ In de natuurkunde is men ceuwenlang op zoek geweest naar de basis-elementen van dingen. Zo zag men atomen en later quarks als de fundamentele bouwstenen waaruit alle dingen waren opgebouwd. Chew zag niet veel heil in dit detaillistisch en element-geïsoleerd onderzoek en wees op de belangrijkheid van de onderlinge relaties van de dingen.

${ }^{17}$ Zoals een werkwoord (activiteit) een relatie legt tussen onderwerp en (lijdend) voorwerp.

${ }^{18}$ In de natuurkunde gebruikt men voor de heschrijving van de beweging van een voorwerp de drie dimensies 'positie', 'snelheid' en 'acceleratie'.
} 
toeneemt. Deze voorspellende waarde bepaalt in belangrijke mate de relevantie van de gegevens en dus de bruikbaarheid en kwaliteit van het management accountingsysteem.

\subsection{Samenvatting}

Nu de management accounting onder druk staat omdat bij de beslissingsrelevantie van de geadministreerde financieel-economische gegevens de nodige vraagtekens worden geplaatst, komt de vraag aan de orde of het klassieke boekhoudmodel niet enige aanpassing behoeft. Dit model, dat thans al zo'n 500 jaar in gebruik is, registreert twee dimensies van het eigen vermogen: samenstelling en ontwikkelingen in de omvang. In tripleentry accounting wordt een derde dimensie toegevoegd, dit betreft ontwikkelingen in de ontwikkeling van de omvang van het eigen vermogen. Het gaat hierbij om ontwikkelingen in de winstcapaciteit van het eigen vermogen van de onderneming. De aanjagers van dergelijke ontwikkelingen zijn winstkrachten. Winstkrachten zijn feiten of gebeurtenissen waardoor het winstpotentieel en, al dan niet onmiddelijk, de winst van de onderneming verandering ondergaat. In een triple-entry accountingsysteem worden deze winstkrachten systematisch geadministreerd. Samengevat kan men stellen dat de drie dimensies in een (differential) triple-entry (wealth) accountingsystcem zijn: samenstelling, omvang en (oorzakelijke) winstmutatics. De extra kosten die met de uitbreiding van de administratie gaan gepaard, dienen te worden gerechtvaardigd door een verhoogde waarde van de gegevens die aan het nieuwe accountingsysteem kunnen worden ontleend.

In een momentum accountingsysteem wordt de winstcapaciteit uitgedrukt als zijnde een winstsnelheid. Dit is de winstcapaciteit per enig tijdstip, uitgedrukt in guldens per een bepaalde periode. Ook wordt binnen dit systeem de ontwikkeling van de winstsnelheid geadministreerd. Daartoe worden de financiële gevolgen van opgetreden winstkrachten uitgedrukt in guldens per een bepaalde periode. In tegenstelling tot het (differential) triple-entry accountingsysteem is een momentum accountingsysteem geen wealth-accountingsysteem, dat wil zeggen: in dit accountingsysteem staat niét de administratie van het eigen vermogen centraal. In een momentum accountingsysteem is het centrale object van adminstratie de 'income momentum', dit is de winstsnelheid van het eigen vermogen. 


\section{Management accounting: verkenning van een vakgebied}

\subsection{Inleiding}

Dit onderzoek naar triple-entry en momentum accounting ligt, zoals later zal blijken, in eerste instantie op het terrein van de management accounting, maar het kan zeker ook belangwekkende resultaten opleveren op het gebied van de financial accounting. Management accounting, ook wel aangeduid als interne berichtgeving of interne verslaglegging, is een verbijzondering binnen het vakgebied accounting. Management accounting is:

"The process of identification, measurement, accumulation, analysis, preparation, interpretation, and communication of financial information used by management to plan, evaluate, and control within an organization" (NAA, 1981).

Aldus is management accounting beschreven als een gespecialiseerd informatiesysteem dat zich bezig houdt met de financieel-economische informatievoorziening ten behoeve van het besturen en het beheersen van een bedrijf. Accounting creëert "economische zichtbaarheid' in een organisatie (Hopwood, 1987:213) ${ }^{1}$.

Management accounting is te onderscheiden van financial accounting.

"The major distinction between them is their use by two different classes of decision-makers. The field of financial accounting serves external decision makers, such as stockholders, suppliers, banks, and governmental agencies. Management accounting serves internal decision makers, such as top executives, department heads, college deans, hospital administrators, and people at other management levels within an organization" (Horngren and Sundem, 1990:4).

In de praktijk is het onderscheid tussen de financial accounting en de management accounting niet altijd eenduidig. Het bedrijfsmanagement baseert zijn beslissingen (mede) op uit externe verslagen beschikbare gegevens, terwijl bijvoorbeeld banken of overne-mende bedrijven hun beslissingen ook baseren op door de betreffende bedrijven beschikbaar gestelde niet-gepubliceerde gegevens.

\footnotetext{
${ }^{1}$ Karl Marx zou het helemaal niet met Hopwood eens zijn geweest Volgens Marx ontstaat ten gevolge van accounting een verwerpelijk bewustzijn en is accounting een middel om in sociale relaties de feitelijke krachten van produktiviteit (in zijn ogen de werknemers) te mystificeren (Marx, 1867:456 e.v.).
} 
"The main difference is that financial accounting is constrained by external reporting requirements and regulation, whereas management accounting can also use less objective and less verifiable information, for example, forecasts and opportunity costs" (Van de Poel, 1986:23).

Afgeleid van de planningscyclus kunnen als belangrijkste functies van het management accountingsysteem worden gezien:

1) Het beschikbaar stellen van gegevens opdat het management 'intelligente' beslissingen kan nemen (hierna te noemen beslissingsondersteuning).

2) Het beschikbaar stellen van gegevens ten behoeve van de eventuele bijsturing van in uitvoer genomen produktie-processen (hierna te noemen beheersing, sturing of 'control').

3) Het beschikbaar stellen van gegevens opdat intern verantwoorde oordeelsvorming inzake de kwaliteit van uitvoerprocessen kan plaatsvinden (hierna te noemen verantwoording ${ }^{2}$.

\subsection{Het management accountingsysteem als een gespecialiseerd informatiesysteem}

Accounting is een onderdeel van de bestuurlijke informatieverzorging zoals geformuleerd door Starreveld (1990:6). Accounting richt zich op de 'vier v's' van financieel-economische gegevens (verzamelen, vastleggen, verwerken en verstrekken). Bij management accounting staan beslissings-ondersteuning en beheersing centraal, alsmede de interne verantwoording van bijvoorbeeld sub-managers aan managers. Bij de financial accounting staat de externe verantwoording centraal, met name van managers aan aandeelhouders. Aldus is management accounting het op interne bedrijfsbehoeften afgestemde (her)ontwerpen en het doen functioneren van een financieel-economisch informatiesysteem.

In algemene zin kan een systeem worden omschreven als:

"A set of interacting components that operate within a boundary for some purpose" (Hicks, 1984:406).

\footnotetext{
2 In ruime zin is onder (2) en (3) evenzeer sprake van beslissingsondersteuning. Bijvoorbeeld, het beschikbaar stellen van gegevens in het kader van de verantwoording vergemakkelijkt de besluitvorming van aandeelhouders die het management al dan niet décharge verlcnen met betrckking tot een bepaald boekjaar. Het onderscheid zoals hier aangebracht is desalniettemin zinvol, omdat de aard van de gegevens die bij de onderscheiden taken in het accountingsysteem moeten worden opgenomen, opdat alle genocmde taken naar behoren kunnen worden uitgevoerd, substantieel verschilt.
} 
Als componenten van een management accountingsysteem kunnen worden aangemerkt a) het bij de accounting functie betrokken personeel en b) de hulpmiddelen zoals computers waarvan bij de gegevensverwerking en -verstrekking gebruik worden gemaakt. Ook kunnen de beoogde gebruikers als een afzonderlijk 'onderdeel' van het management accountingsysteem worden beschouwd. Dit is met name zinvol in het kader van het systeemontwerp en bij de beoordeling van de systeemkwaliteit.

In een bedrijf manifesteert zich een management accountingsysteem vaak als 'een systeem van systemen'. Zo kunnen binnen het management accountingsysteem subsystemen voorkomen zoals een boekhoudsysteem, een budgetsysteem, een transferprijssysteem, een kostprijssysteem en een prestatiebeoordelingssysteem.

Oorspronkelijk werd verondersteld dat de behoeften van de gebruikers van het accountingsysteem voorspelbaar en dus bekend waren. In deze gevallen kan de systeemontwerper uitmaken wat de frequentie van de gegevensverstrekking is, de mate van detail respectievelijk aggregatie, het te hanteren waarderingsstelsel, enzovoort. Deze benadering werd door de 'value school' of 'user-need school' voorgestaan (Belkaoui, 1992:110). In tegenstelling hiertoe worden bij de 'events approach' dergelijke aspecten aan de gebruiker overgelaten. Deze laatste benadering komt er op neer dat vele gegevens in onbewerkte staat in een groot bestand worden opgeslagen (data-base benadering). Hiermee kan de gebruiker dan zijn eigen manipulaties uitvoeren. Bekend aanhanger van de 'events approach' is Sorter (1969). De object-georiënteerde 'events-approach' voor het ontwerp van management accounting systemen is gebaseerd op theorieën uit de accounting, uit de computerwetenschappen en op resultaten uit onderzoek naar kunstmatige intelligentie (Kandelin en Lin, 1992:41).

In deze paragraaf is management accounting beschreven als een financieel-economisch informatiesysteem. In deze visie is een marktonderzoeker die in opdracht van een bedrijf consumenten interviewt teneinde gegevens te verzamelen over de afzetmogelijkheden van een nieuw produkt, ook met accounting bezig. Dit is evenwel niet het geval en wel om deze reden dat er tussen de ondervraagde consumenten en het betreffende bedrijf geen verantwoordelijkheidsrelatie bestaat. De ondervraagde consumenten zijn voor hun doen en laten geen verantwoording verschuldigd aan het betreffende bedrijf. Dit ligt anders wanneer iemand in opdracht van het management van een bedrijf gegevens verzamelt over bijvoorbeeld het functioneren van afdelingshoofden binnen dat bedrijf. Deze afdelingshoofden zijn wel rekening en verantwoording verschuldigd, in dit geval aan het hogere management. Management accounting vindt plaats in een dergelijk kader van verantwoordelijkheidsrelaties. Dit brengt specifieke problemen met zich mee, zoals ten aanzien van de betrouwbaarheid van de (vaak door de ter verantwoording gehoudene zelf) verstrekte gegevens. In paragraaf 2.4 wordt dit aspect nader uitgewerkt. 


\subsection{Management accounting en management control}

In algemene zin is besturing of bcheersing ('control') een proces waarbij zorg wordt gedragen voor het feit dat een systeem zich aanpast aan zijn omgeving door terugkoppeling (feedback). Dit betekent dat het systeem wordt geconfronteerd met zijn eigen resultaten en daarop reageert wanneer deze teleurstellend zijn $^{3}$. Management control is de besturing van een organisatie door het betreffende management. Het management accountingsysteem is 'one type of control mechanism' [Waterhouse en Tiessen, 1978:62]. De financiële rapportage is slechts het beginpunt voor management control en geen eindpunt (Lewy, 1992:18).

Anthony, Dearden en Bedford omschrijven management control als

"...all methods, procedures, and devices, including management control systems, that management uses to ensure compliance with organization policies and strategies" (Anthony, Dearden en Bedford, 1989:6).

In deze omschrijving ligt zowel een externe als een interne component besloten. Extern gaat het om het ontwikkelen van op interne mogelijkheden en op marktposities en bewegingen afgestemde ondernemingsstrategieën. Intern gaat het om het stimuleren van bedrijfsmedewerkers op een dusdanige wijze dat zij daadwerkelijk doen wat van hen wordt verwacht.

Hofstede (1981:196) definieert management control als:

"...a pragmatic concern for results, obtained through people".

Hiermee zijn meteen de drie belangrijke aspecten van management control geschetst: pragmatisme, resultaatgerichtheid en mensen.

Een management controlsysteem is:

"...an organized systematic process and structure that management uses in management control" (Anthony, Dearden en Bedford, 1989:6).

Het management controlsysteem ondersteunt het management bij het tot stand brengen van zowel de externe als de interne coördinatie en beheersing. Dit gebeurt met name doo het verzamelen, vastleggen, verwerken en verstrekken van hiervoor relevante gegevens.

\footnotetext{
${ }^{3}$ Dit kan worden vergeleken met het functioneren van de centrale verwarming die wordt bestuurd via een thermostaat.
} 
Voor een bepaald deel, afhankelijk van met name bedrijfsomvang, produktie-complexiteit, organisatie-structuur en -cultuur, vindt deze administratie plaats binnen het accountingsysteem.

Algemeen worden binnen management control twee (complementaire) categorieën stuurvariabelen onderscheiden:

1) Uitvoer-georiënteerde beheersing.

Hiertoe worden specifieke bedrijfsuitkomsten gemeten en vergeleken met hieromtrent ingestelde normen. Ook administratieve controles en voor bepaalde handelingen te volgen formele procedures (handleidingen) vallen hieronder.

2) Invoer-georiënteerde beheersing. Zelfbeheersing, gedeelde waarden en normen, selectie van personeel op bepaalde vaardigheden en houding en de sturing die van een groep uitgaat op een individu binnen die groep, zijn voorbeelden van dergelijke stuurvariabelen.

Welk type beheersing in een bepaalde situatie het meest adequaat is, is voor een groot deel afhankelijk van de (on)zekerheid waarmee de processen waarop de stuurvariabelen betrekking hebben, kunnen worden uitgevoerd. Indien de produktieprocessen vrij stabicl van patroon zijn, is uitvoer-georiënteerde beheersing geschikt. In andere gevallen is invoer-georiënteerde sturing vaak geschikter. Concreet betekent dit dat bijvourbecld in de marketing minder snel met budgetten gewerkt zal worden dan in de produktie of worden de budgetten op een andere wijze opgesteld (Cunningham, 1992:96).

Traditioneel wordt een management accountingsysteem tot de eerste categorie stuurvariabelen gerekend. Echter, management accounting is ook een taal en derhalve een onderdeel van een communicatiesysteem. In die zin kan management accounting ook een belangrijke rol spelen in de invoer-georiënteerde sturing.

Management control is gericht op en handelt over mensen. Het voorspellen en ook de sturing van menselijk gedrag is evenwel nog maar beperkt ontwikkeld. Om die reden kan management control (nog) niet als een 'wetenschap' worden aangemerkt (Euske, 1984:2).

Mintzberg onderscheidt een zestal coördinatie-mechanismen en typeert op basis hiervan de in de praktijk voorkomende organisaties (Mintzberg, 1989:101) ${ }^{4}$ :

\footnotetext{
${ }^{4}$ Hierbij dient te worden bedacht dat van de verschillende organisatietypen casu quo controltypen zich vaak tegelijkertijd meerdere in één organisatie manifesteren.
} 
1) 'Mutual adjustment'. Dit is het onderling afstemmen van werkzaamheden op basis van informele communicatie zoals dat met name in jonge dynamische organisaties ('adhocracies') plaatsvindt.

2) 'Direct supervision'. Hierbij grijpt de leiding op basis van direct toezicht in wanneer processen niet conform de doelstelling worden uitgevoerd. In kleinere organisaties ('simple structures') komt coördinatie op basis van 'direct supervision' het meeste voor.

3) 'Standardization of work processes'. In 'machine bureaucracies' staat het produktieproces centraal en worden voor de te verrichten werkzaamheden standaardinstructies en -procedures opgesteld.

4) 'Standardization of outputs'. Hierbij worden normen voor de (financiële) uitkomsten van het produktieproces gesteld. Deze vorm van coördinatie vindt met name plaats in gedivisionaliseerde organisaties ('divisionalized form').

5) 'Standardization of skills (as well of knowledge)'. Feitelijk is dit standaardisatie van de input omdat in dit geval bij de personeelsselectie alleen die mensen worden aangenomen die voldoen aan bepaalde opleidings-eisen. Ook vervolgtrainingen behoren hiertoe. Mintzberg spreekt hier van 'professional bureaucracies'.

6) 'Standardization of norms'. Dit beheersingsmiddel is later door Mintzberg toegevoegd. Het komt er op neer dat men alle medewerkers probeert te laten functioneren van uit een gemeenschappelijke set van normen en waarden zoals dat in een godsdienst of politieke partij ook gebeurt. Dit zijn de 'missionary configurations'.

De functie van accounting zal in elk van de genoemde typen organisaties anders zijn. De accountant zal de toe te passen standaards (normen) mede opstellen, hij zal nagaan in hoeverre de feitelijke uitvoering met die normen overeenkomt, hij zal eventuele verschillen tussen norm en uitvoering vroegtijdig rapporteren zodat bijsturing van de uitvoering kan plaatsvinden casu quo bijstelling van de norm (dan wel van beide) en hij zal definitieve verschillen (eindresultaten) aan een nadere analyse onderwerpen. Maar het zal duidelijk zijn dat deze taken volstrekt anders liggen in bijvoorbeeld een innovatieve organisatie waarbij de coördinatie vooral door informeel overleg plaatsvindt dan in een sterk gediversificeerde onderneming waarin de coördinatie in hoofdzaak plaatsvindt door het stellen van normen aan (financiële) eindresultaten. In ieder geval kan worden gesteld dat de coördinatie binnen elke (grotere) organisatie in belangrijke mate steunt op de management accounting (Bouma, 1992:10). En derhalve dient het management accountingsysteem een geïntegreerd onderdeel te zijn van het management controlsysteem (Waterhouse en Tiessen, 1978:65; Flamholz, 1983:148).

Bij de klassieke veronderstellingen in de management control en accounting over werk en over mensen (sleutelveronderstellingen uit het industriële tijdperk) worden tegenwoordig de nodige vraagtekens geplaatst. Werk hoeft niet altijd saai en vervelend te zijn en 
mensen zijn niet per definitie liever lui dan moe. Zoals Ross (1990:51) opmerkt, dienen de huidige systemen meer op 'vertrouwen' dan op 'wantrouwen' te worden gestoeld. Management control is een sociaal proces dat zich afspeelt in een sociale omgeving. Het is in elk geval niet puur cybernetisch en dus een technisch-mechanistisch proces. Het is deze cybernetische benadering die vele management control systemen ineffectief doet zijn. Hofstede (1978:453) pleit voor een andere visie op management control door te spreken van homeostatische processen. Dergelijke processen vinden plaats in politieke atmosferen: besluitvorming komt tot stand op basis van onderhandelingen en persoonlijke (derhalve niet altijd objectieve) oordelen. Een dergelijke benadering van management control eist andere controllers en andere informatiesystemen. De inhoud en structuur van het controlsysteem hangen derhalve in sterke mate af van de manier waarop tegen een organisatie wordt aangekeken.

De effectiviteit van een management controlsysteem hangt af van de kwaliteit van de uitwerking van een drietal issues (Anthony, 1989:24-28):

1) 'Measuring'. Dit komt neer op het uitmaken van wat onder goed/slecht presteren zal worden verstaan en het selecteren van een waarnemer ('monitor') zoals een accountingsysteem. Dit is een belangrijk aspect omdat, zoals Dearden opmerkt:

"The methods used to measure managers affect the way they act" (1987:88).

2) 'Evaluating'. Hierbij worden keuzen gemaakt inzake beoordelingsmaatstaven zoals budgetten en prestaties van derden.

3) 'Rewarding'. 'Rewarding' komt neer op het verbinden van bepaalde beloningsconsequenties aan de gemeten en beoordeelde prestatie.

In de normatieve accountingliteratuur worden de hiervoor geschetste functies van management accounting - ondersteuning van besluitvorming en bedrijfśseheersing en middel tot het afleggen van rekening en verantwoording - bij herhaling genoemd. Het gaat er dan om dat via management accounting onzekerheid binnen organisaties tot acceptabele proporties wordt teruggebracht. Maar, omdat in control en accounting vele oorzaak-gevolg relaties bestaan die niet (volledig) zijn gedetermineerd, blijft altijd onzekerheid bestaan of een bepaalde maatregel al dan niet tot het gewenste effect leidt. Onzekerheid die door een bepaalde maatregel wordt weggenomen bij de ene partij, kan de onzekerheid bij een andere geaffilieerde partij doen toenemen. Aldus is een spanningsveld aanwezig waarin belangenconflicten bestaan. De machtstructuur in een bedrijf bepaalt uiteindelijk de plaats waar onzekerheid en dus de risico's worden gelegd. Binnen dit deels politieke proces krijgt accounting uiteindelijk gestalte. 
Management control is het sturen van een bedrijf op een dusdanige wijze dat de gestelde doeleinden zo goed mogelijk worden bereikt. Hierbij staat de totale organisatie centraal en dus niet een bepaalde taak of transactie dan wel afwijkingen ten opzichte van een bepaalde, aan een afdeling opgelegde norm (Anthony, 1989:25). Dit betekent dat er ten behoeve van de management control behoefte bestaat aan een integrerend element en er bestait geen frequenter gebruikt middel hiertoe dan het geld (als omrekenmiddel). Door het omrekenen in geld worden de diverse deelactiviteiten en bedrijfsonderdelen op een gemeenschappelijke noemer gebracht, waardoor sturing van het totale bedrijf mogelijk wordt. Hiermee is tevens het verband aangegeven met de management accounting waarbij het immers gaat om financieel-economische gegevensverwerking. In een aantal gevallen overheerst deze getalsmatige component in de management control waarbij men dan spreekt van 'accounting based control' of (het kosten-georiënteerde) 'managing by numbers'. Maar, zoals gezegd, in de management control staat in wezen de produktiefactor 'mens' centraal en is niet de accounting of economie de basisdiscipline maar de psychologie (Anthony, 1989:25). Wanneer dan management control en management accounting zo nauw met elkaar zijn verweven, mag men verwachten dat in de management accounting en de literatuur op dit terrein aan dergelijke aspecten voldoende aandacht wordt gegeven.

Na cen uitvoerig literatuur-onderzoek van de belangrijkste onderwerpen op het gebied van de management accounting komt Scapens tot het volgende overzicht (zie tabel 2.1). Dit overzicht onderstreept de instrumentele benadering van het vakgebied en toont aan dat gedragswetenschappelijke aspecten nog niet of nauwelijks aandacht krijgen.

\subsection{Verschillende benaderingen van accounting; positionering van het triple-entry en momentum accountingonderzoek}

De benadering van accounting als een informatiesysteem, als een systeem dat gegevens verzamelt, verwerkt en verstrekt ten einde de financieel-economische besluitvorming te ondersteunen, staat bekend als 'decision-approach to accounting' (ook genoemd 'the user-decision-making approach'; zie Kaplan en Atkinson, 1989:9) ${ }^{5}$.

\footnotetext{
5 ljiri over de 'decision approach': "Under the decision approach, the objective of accounting is to provide information useful in economic decision making" (Jiri, 1982:39).
} 
Tabel 2.1 De belangrijkste onderwerpen op het gebied van de management accounting. (Scapens, 1985:11)

1. Planning:

Relevant costs for decisions

Cost-volume-profit analysis

Product mix decisions

Other decisions: e.g. economic order quantities

2. Cost classifications:

Fixed and variable costs

Cost estimation techniques

Forecasting costs

Learning curves

3. Control:

Responsibility accounting

Budgeting and standard costing

Variance analysis

4. Costing:

Job order and process costing

Variable and absorption costing

Cost allocation (including service department costs)

5. Divisionalised organisations:

Performance evaluation

Transfer pricing

Een management accountingsysteem is echter meer dan een informatiesysteem alleen. Een belangrijk deel van de hedendaagse accountingpraktijk kan niet worden verklaard en lijkt zelfs inconsistent en irrationeel indien daarop uitsluitend de 'decision approach' wordt geprojecteerd (Belkaoui, 1992:499). Ijiri verwoordt dit aspect als volgt:

"However, to view accounting as a system of supplying information useful for decisionmaking is only one approach. Along with it, there is another important approach to accounting which may be called the accountability approach" (Ijiri, 1982:39).

'Accountability' kan worden omschreven als de verplichting van het management rekening en verantwoording af te leggen over de met het beschikbare vermogen bereikte resultaten (Ijiri, 1975:ix). In de zin van 'accountability' is het accountingsysteem een 
belangrijk middel om gevoerd beleid te evalueren ${ }^{6}$. De in paragraaf 2.1 beschreven eerste twee taken van een accountingsysteem (beslissingsondersteuning en beheersing) worden gedekt door de 'decision approach', de derde functie door de 'accountability approach'.

Ook Belkaoui onderkent expliciet twee benaderingen van accountingsystemen.

"Accounting is assumed to be action oriented; its purpose is to influence action (behavior) directly through the informational content of the message conveyed and indirectly through the behavior of accountants" (Belkaoui, 1992:114).

Het directe effect van accounting volgt uit de 'decision approach', dat wil zeggen: door het beschikbaar stellen van accountingdata zullen beslissingen en daarmee het gedrag van medewerkers kunnen worden beïnvloed. Het indirecte effect van accounting volgt uit de 'accountability approach', dat wil zeggen: uit het feit dat medewerkers er zich bewust van zijn dat zij over hun gedragingen rekening en verantwoording moeten afleggen, nodigt hen a priori uit tot gedrag dat meer in overeenstemming is met het door de opdrachtgever beoogde gedrag. Prakash en Rappaport spreken in dit verband van 'information inductan$c e^{\prime}$, dat wil zeggen: het gedrag van een individu wordt beïnvloed door de gegevens welke hij of zij over dat gedrag ter beschikking dient te stellen.

"An individual's anticipating the consequences of his or her communication might lead him or her-before any information is communicated and, hence, even before any consequences arise, to choose to alter the information, or his or her behavior, or even his or her objectives. This is the proces of information inductance". (Prakash en Rappaport, 1977:32).

Wanneer binnen de management accounting rekening wordt gehouden met aspecten van menselijk gedrag, wordt de band met de management control versterkt. Management control is immers mens-georiënteerd.

In de definitie van management accounting van de 'International Federation of Accountants' (IFAC) wordt het accountability-aspect expliciet genoemd.

\footnotetext{
' 'Accountability' kan kort als 'evaluatie' worden aangeduid (Wolk, Francis en Tearney, 1992:186). Ook in het IASC-conceptual framework wordt deze functie van accounting nadrukkelijk onderkend. "Financial statements also show the result of the stewardship of management, or the accountability of management for the resources entrusted to it" (IASC, 1989:11).
} 
"Management accounting may be defined as the process of identification, measurement, accumulation, analysis, preparation, interpretation, and communication of information (both financial and operating) used by management to plan, evaluate, and control within an organization and to assure use of and accountability for resources" (IFAC, deel 2, 1989:1315).

In tegenstelling tot de 'decision approach' die twee partijen erkent, (1) de informatiegebruiker en (2) de management-accountant als 'producent' van informatie, gaat de accountability benadering uit van het bestaan van drie partijen: (1) een accountee, (2) een accountor en (3) een controlerend accountant ${ }^{7}$ als een onafhankelijk informatie-deskundi$\mathrm{ge}^{8}$. Tussen accountor en accountee wordt geacht een bepaalde verantwoordelijkheidsrelatie te bestaan. Accountor is de partij die verantwoording moet afleggen. Accountee is de partij aan wie verantwoording is verschuldigd. In de regel wordt aan de verantwoordingsplicht formeel gevolg gegeven doordat de accountor een administratie voert op basis waarvan periodiek een samengevat (financieel-economisch) verslag wordt uitgebracht aan de accountee.

De verantwoordelijkheidsrelatie tussen accountor en accountee kan op diverse grondslagen berusten. Bedrijfsvoorschriften, gewoontes en morele verplichtingen zijn hiervan voorbeelden. Meestal berust de relatie op een contract dat partijen zijn aangegaan, zoals het top-management dat sub-managers inhuurt waamaar bepaalde taken en bevoegdheden worden gedelegeerd. Maar ook uit hoofde van bijvoorbeeld wetgeving bestaan vaak dergelijke relaties, zoals ten aanzien van top-management en aandeelhouders of erfgenamen en een door de erflater benoemde bewindvoerder.

In dit triple-entry en momentum accountingonderzoek zijn verantwoordelijkheidsrelaties nader geanalyseerd conform de agency-theorie. Naast de 'decision-model approach', 'behavioral research', 'capital market research' en 'information economics' is de agency-theory een van de belangrijkste richtingen die men in het huidige accountingonderzoek

\footnotetext{
${ }^{7}$ De Angelsaksische betekenis van 'accountant' is afwijkend van de in ons land gangbare. Een accouniant is daar en in dit proefschrift niet een onafhankelijk deskundige die door derden overgelegde financiěle jaarstukken controleert en daardoor geloofwaardigheid aan de stukken toevoegt (in Angelsaksische betekenis is dit cen 'auditor'), maar iemand die zich (onder andere) bezig houdt met het opmaken van jaarstukken. Hier te lande valt deze taak meestal onder die van de 'controller' casu quo de interne accountant.

${ }^{8}$ In de informatica maakt men algemeen een onderscheid ussen gegevens en informatie. Gegevens zijn tekens zoals getallen en letters die in een of andere vorm zijn opgeslagen, bijvoorbeeld gebeiteld in steen of magnetisch vastgelegd op schijf. Gegevens zijn concreet, dat wil zeggen objectief fysiek waarneembaar. Informatie is de betekenis die iemand tockent aan ter beschikking gestelde gegevens (voor deze 'interpretatie' is kennis nodig). Informatie speelt zich dus af in het hoofd van mensen en is daardoor abstract en subjectief. In deze zin zou hier steeds van (accounting) gegevens dienen te worden gesproken.

${ }^{9}$ Hierbij wordt onderzocht hos de kapitaalmarkt reageen op door bedrijven openbaar gemaakie nieuwe gegevens.
} 
onderkent ${ }^{10}$ (Wolk, Francis en Tearney, 1992:39-42; zie ook Kaplan en Atkinson, 1989:9-12). Het betreft hier verschillende paradigma's die in de accountingwetenschap worden toegepast ${ }^{11}$.

De 'information economics approach' kan worden gezien als een uitbreiding van de 'decision approach to accounting' (Kaplan en Atkinson, 1989:10). In deze benadering wordt een management accountingsysteem gezien als een gespecialiseerd informatiesysteem en accountinginformatie wordt beschouwd als een goed dat geld kost om het te produceren. Daarom bestaat er ook geen a priori behoefte aan gegevens. De kosten moeten worden gerechtvaardigd doordat op basis van de verstrekte gegevens betere beslissingen kunnen worden genomen. Deze 'verbetering' kan bijvoorbeeld worden gemeten aan de omvang van het bereikte resultaat in combinatie met het daarover gelopen risico. In het algemeen kunnen de volgende resultaten (na aftrek van informatiekosten) worden bereikt:

Tabel 2.2 Mogelijke resultaten van ter beschikking gestelde accountinggegevens.

\begin{tabular}{|l|r|r|r|r|r|r|r|r|r|}
\hline \multicolumn{10}{|c|}{ effecten accountingegevens } \\
\hline siruatie & a & b & c & d & e & f & g & h & i \\
\hline $\begin{array}{l}\text { resultaat/ } \\
\text { beloning }\end{array}$ & + & + & + & - & - & -1 & 0 & 0 & 0 \\
\hline risico & + & $-/$ & 0 & + & $\digamma$ & 0 & + & $-\%$ & 0 \\
\hline
\end{tabular}

$$
\begin{aligned}
& +=\text { toename } \\
& -/=\text { afname } \\
& 0=\text { geen verandering }
\end{aligned}
$$

Uitgaande van rationeel handelen waarbij resultaat positief wordt gewaardeerd en risico negatief, zijn de situaties $d, f, g$ en i in ieder geval ongewenst, dat wil zeggen: de verstrekte accountinggegevens zijn nutteloos.

Een belangrijke bijdrage van het 'information economics' onderzoek is geweest dat men systeemontwerp en systeemkeuze nadrukkelijk als twee vraagstukken is gaan zien (Scapens, 1985:120). Eenvoudige en ogenschijnlijk irrationele calculatiemethoden zoals die in de praktijk vaak worden aangetroffen, blijken rationele keuzen te zijn wanneer wordt rekening gehouden met informatiekosten (zie ook van Dijk, 1993:504).

\footnotetext{
${ }^{10}$ Hierbij kan de agency-theorie als een bijzondere toepassing van 'behavioral research' worden beschouwd.

"Accounting is 'a multiple-paradigm science' (Belkaoui,1992:498). Volgens $K u h n$ is dit een "contradictio in terminus". Om te kunnen spreken van een wetenschap dient een bepaald paradigma op een gegeven moment te domineren (Kuhn, 1970:15). Hiervan is op dit moment geen sprake. De genoemde paradigma's concurreren met elkaar en brede consensus lijkt nog ver weg.
} 


\subsubsection{Het agencyparadigma}

De agency-theorie is een benadering die zich bezig houdt met de vraag waarom individuen niet samenwerken, terwijl het gevolg van deze samenwerking de welvaart van een der partijen zou kunnen doen verhogen zonder die van de andere partij te schaden. De agency-theorie is een uitbreiding van de 'information economics' benadering omdat zowel met onzekerheid als informatiekosten en bepaalde aspecten van menselijk gedrag rekening wordt gehouden (Scapens, 1985:169). In agency-analyses wordt de relatie accountoraccountee aangeduid als een principaal-agent relatie, terwijl een onderneming wordt gezien als een netwerk van dergelijke relaties.

"The agency literature, as applied to the firm, has primarily adopted the image of the firm as a nexus of contracts" (Schreuder, 1985:11).

De principaal delegeert de verantwoordelijkheid voor bepaalde beslissingen naar de agent. Verondersteld wordt nu dat principaal en agent een belangenconflict hebben. Beide partijen zijn er op uit hun eigen belang zo goed als mogelijk te behartigen. Dit gebeurt door een gemeenschappelijk gedragen risico dusdanig te manipuleren dat het zo veel mogelijk bij de andere partij komt te liggen. Een agent wordt verondersteld liever lui dan moe te zijn. Een contract, waarin opgenomen een bepaalde vergoeding voor de agent, is nodig ten einde de diverse belangen (enigszins) gelijk te richten en verval in anarchie van de onderneming te voorkomen ${ }^{12}$. Het agency-onderzoek richt zich in dit verband op het ontwerpen van optimale contracten, dat wil zeggen contracten waarbij de gezamenlijke welvaart van agent en principaal maximaal is. Bij dit punt geldt dat er een optimale verdeling tot stand is gebracht tussen beloning en risico's. Ten einde deze doelstelling te kunnen bereiken zullen de betrokken partijen afspraken moeten maken, met name over zaken aangaande:

1) De beloning voor de agent ('incentive compensation plans');

2) Door de principaal gehanteerde sturende voorschriften ten aanzien van het gedrag van de agent en evaluaties van bereikte resultaten ('monitoring');

3) Beperkende voorschriften die de agent aanbiedt zich op te leggen om zodoende bij de principaal de indruk te wekken dat geen acties worden ondernomen die niet in diens belang zijn ('bonding'). Deze afspraken verminderen de neiging bij de principaal om aan uitgebreide 'monitoring' te doen. Hierdoor nemen de kosten van 'monitoring' af waardoor de totale vergoeding die tussen principaal en agent kan worden verdeeld, toeneemt. Een vrijwillige accountantscontrole is een voorbeeld van 'bonding'.

\footnotetext{
${ }^{12}$ Jensen en Meckling beschrijven dit als volgt: "... firms are legal fictions which serve as a nexus for a set of contracting relationships among individuals" (Jensen en Meckling, 1976:31).
} 
Zelfs bij goed functionerende beloningscontracten en bij hoge uitgaven voor 'monitoring' en 'bonding' blijft de mogelijkheid bestaan dat het handelen van de agent niet volledig in overeenstemming is met het belang van de principaal. Het hiermee gepaard gaande verlies voor de principaal wordt 'residual loss' genoemd. De kosten uit hoofde van het contract welke de principaal maakt ('agency costs') zijn nu gelijk aan de uitgaven in verband met 'monitoring' en 'bonding', alsmede het 'residual loss'. Een management accountingsysteem kan in dit licht worden bezien als een belangrijk ('monitoring') instrument dat wordt gehanteerd om de agency-kosten zoveel als mogelijk te beperken (Belkaoui, 1992:157).

Algemeen worden twee richtingen binnen de agency-theorie onderscheiden: het principaal-agent onderzoek en de positieve agency-theorie.

Het principaal-agent onderzoek is vrij wiskundig en analytisch van aard. Het is gebaseerd op ervaringen met contracten opgedaan in de verzekeringswereld en later toegepast in onder andere werknemerscontracten en budgettering. Centraal staan twee informatieproblemen: 'adverse selection' en 'moral hazard'. 'Adverse selection' betreft een ex ante informatieprobleem en het ontstaat uit het feit dat het voor de ene partij, de verzekeraar, praktisch onmogelijk c.q. te kostbaar is alle gegevens te verzamelen waarover de andere partij, de (aspirant)verzekerde, beschikt. Door deze informatie-asymmetrie zit de verzekeraar met een extra risico. Wanneer de reactie van de verzekeraar hierop een premieverhoging is, leidt dit in vele gevallen er toe dat verzekerden waarmee de verzekeraar weinig risico loopt minder verzekeringen zullen willen afsluiten. Hiermee ontstaat voor de verzekeraar een verliesgevende situatie. 'Moral hazard' is een ex-post informatieproblecm. Ondat de verzekerde weet dat hij in geval van schade een uitkering tegemoet kan zien, voelt deze zich niet verplicht risico's te vermijden of zoekt deze zelfs op. Het door de agent in eigen belang manipuleren van voor de principaal (economisch) niet controleerbare gegevens behoort hiertoe, alsmede het (mis)bruiken van private gegevens om daarmee voordeel te behalen uit het met de principaal aangegane contract. 'Adverse selection' zowel als 'moral hazard' kunnen onder andere worden tegengegaan door het beschikbaar stellen van een bonus bij het bereiken van een bepaald prestatieniveau.

De positieve agency theorie houdt zich bezig met het beschrijven en verklaren van de contracten die in de praktijk worden aangetroffen en de effecten van deze contracten op de onderneming als totaliteit. Als zodanig is deze theorie niet normatief zoals de principaal-agent literatuur, maar beschrijvend van aard. De positieve agency theorie is een voorbeeld van 'positive accounting' zoals met name gepropageerd door Watts en Zimmerman (1986). Hierin staat empirisch onderzoek centraal op basis waarvan men een verklaring voor de werkelijkheid tracht te vinden. Dit in tegenstelling tot normatief onderzoek waarin wordt getracht aan te geven hoe die werkelijkheid er idealiter zou moeten uitzien. Het onderhavige triple-entry en momentum accountingonderzoek is in zoverre normatief dat het voorschriften bevat voor de (administratieve) inrichting van de 
werkelijkheid en is derhalve, zoals Kaplan dat noemt, een vorm van 'academic management accounting' (Kaplan, 1986:9).

Het agency-paradigma wordt vaak gebruikt om het bestaan van bepaalde institutionele accounting-fenomenen zoals accountantscontrole te verklaren. Indien ervan wordt uitgegaan dat partijen in eerste instantie hun eigen belang dienen, ligt het min of meer voor de hand dat de principaal een door de agent overgelegd financieel verslag op zijn getrouwheid laat controleren door een onafhankelijke instantie.

Ook op het gebied van de control heeft agency-onderzoek interessante uitkomsten opgeleverd. Met behulp van het principaal-agent model kan worden aangetoond dat agenten in bepaalde mate mede-verantwoordelijk moeten zijn voor niet-beheersbare factoren (dit is overigens in tegenspraak met het basisprincipe van control) zodat zij een deel van het risico van de principaal meedragen. In de beslissingen van de agent wordt zodoende dit risico gereflecteerd en kan een voor beide partijen Pareto optimale situatie worden gecreëerd (Demski, 1976:233). De agent wordt in dit verband geacht risicomijdend te zijn en de principaal risico-indifferent (omdat hij deze risico's kan beheersen via diversificatie).

Belangrijkste voordeel van het agency-paradigma is dat het zowel voor interne als voor externe accountingvraagstukken kan worden toegepast. Omdat de verwachting van het onderhavige triple-entry en momentum accountingonderzoek is dat de resultaten hiervan zowel van belang zijn voor de interne als de externe financiële verslaglegging, is dit een materieel voordeel.

Wanneer wordt verondersteld dat agent en principaal onopgeloste belangen-tegenstellingen kunnen hebben, heeft dit gevolgen voor het beoordelen van door partijen beschikbaar gestelde financieel-economische gegevens. Bijvoorbeeld in investeringscalculaties worden cash flows doelbewust gemanipuleerd ten einde de persoonlijke aspiraties alsnog beter te kunnen dienen.

"In general a political and behavioural dimension is needed in modelling decision-making. The traditional approach has to assume that these dimensions can be ignored and that people will give objectively best estimates. Agency theory, on the other hand, provides a frame-work within which these issues can be considered" (Fox, 1984:36).

Ook de inhoud van het financieel verslag waarmee de agent rekening en verantwoording aflegt, dient in dit licht te worden bezien. De agent zal bijvoorbeeld bepaalde kosten van machine-onderhoud en research willen drukken opdat de winst die hij kan rapporteren hoger wordt waardoor hij een hogere salaris-bonus ontvangt, dan wel promotie kan maken. Een en ander dus op kosten van zijn principaal. Deze veronderstelling is in overeenstemming met de bevindingen van Merchant bij een uitgebreid onderzoek in de 
Verenigde Staten naar de beloningsstructuur voor en het op basis daarvan mogelijk uitgelokt manipulatief gedrag van managers van profit centers. Merchant maakt wat dit laatste betreft een onderscheid tussen 'accounting methods of managing earnings' en 'operating methods of managing earnings'. In het eerste geval gaat het om het manipuleren van accounting-gegevens (zoals het muteren van voorzieningen of het activeren van uitgaven) opdat het gewenste korte-termijn winstniveau kan worden gerapporteerd (het gaat hierbij om beslissingen welke de administratie van transacties beïnvloeden). Operationele methoden waarmee het te rapporteren resultaat doelbewust kan worden beïnvloed, muteren behalve het winstniveau tegelijkertijd de cash flow. Enkele voorbeelden van dergelijke transactie-beïnloedende beslissingen zijn: Het 'vasthouden' van afleveringen, het vervroegen van omzet via extra kortingen en het uitstellen van onderhoud. Van de 54 door Merchant ondervraagde managers gaven 36 toe de een of andere vorm van winstmanipulatie te hebben toegepast.

"...almost twice as many profit center managers use operating methods of managing earnings as use accounting methods. Detecting accounting manipulations is easier, because the accounting rules are written, and accounting judgments are expected to be made consistently and conservatively" (Merchant, 1989:172-175).

Kennelijk is het mogelijk om op basis van het accountingsysteem bepaald manipulatief gedrag objectief te expliciteren en als zodanig remt dit systeem disfunctioneel gedrag af. Maar niet elke vorm van manipulatief gedrag wordt via het (twee-dimensionale) accountingsysteem opgemerkt, met name niet bij de operationele methoden. Ook de accountant die als een derde (onafhankelijke) partij tussen principaal en agent wordt gevoegd ten einde de geloofwaardigheid van de overgelegde stukken te bevestigen, lost dit probleem niet (volledig) op.

"With the operating methods of managing earnings, the accounting can be said to "fairly present" what actually happened, but the changes in the operating decisions have the same. effect as the accounting methods; they either boost or "save" reported income ..." (Merchant, 1989:171). 


\subsubsection{Agencyparadigma en het triple-entry en momentum accounting- onderzoek}

In het onderhavige triple-entry en momentum accountingonderzoek worden ook de effecten geanalyseerd welke een drie-dimensionaal accountingsysteem kan hebben op het gebruik van accounting en op operationele methoden ten einde het winstcijfer te sturen.

In de accountability-benadering meet accounting niet alleen het gedrag van mensen in organisaties, maar beïnvloedt dat ook a priori (men kan dit zien in het licht van de 'onzekerheidsrelatie van Heisenberg ${ }^{13}$ ). Dit laatste gebeurt doordat agenten hun gedrag aanpassen, dat wil zeggen zich in de ogen van de principaal meer verantwoord gedragen, omdat zij weten dat over hun gedrag verslag wordt gedaan en zij op basis daarvan worden beoordeeld ${ }^{14}$. Het accountingsysteem kan als zodanig een belangrijk beheersinstrument zijn voor de principaal: het synchroniseert (in bepaalde mate) de belangen van de principaal en de handelingen van diens agent(en). Wanneer het gedragsmatige aspect van het accountingsysteem onvoldoende wordt onderkend, kan het systeem suboptimaal functioneren omdat het bijvoorbeeld de agenten aanspoort tot manipulatie van gegevens of korte-termijn gedrag. Uiteindelijk kan dit de principaal veel geld kosten.

"...the potential costs of control systems can be much greater than just the out-of-pocket costs" (Merchant, 1990:311).

Uit de accountability-benadering van accounting kan worden afgeleid dat zelfs wanneer de opdrachtgever-principaal nimmer financiële verslagen gebruikt bij zijn besluitvorming of zelfs maar leest, de wenselijkheid van het implementeren van een accountingsysteem daardoor niet per definitie vervalt. Het voordeel voor de principaal in relatie tot de kosten van het accountingsysteem moet dan met name komen uit het verantwoorder gedrag van de agent dankzij het bestaan van het accountingsysteem. Dit wil zeggen, het feitelijk gedrag van de agent is (meer) in overeenstemming met het door de principaal beoogde gedrag van de agent.

Een ander belangrijk aspect is dat bepaalde aan gegevens te stellen kwaliteitseisen zoals objectiviteit en controleerbaarheid pas inhoud krijgen wanneer tussen partijen een belangenconflict wordt verondersteld met betrekking tot de inhoud van de financiële verslaglegging.

\footnotetext{
${ }^{13}$ Deze onzekerheidsrelatie geeft de mate aan waarin de wetenschapper ten gevolge van meetprocessen de eigenschappen beïnvloedt van de objecten die hij waarneemt. Hiermee is aangegeven dat een wetenschapper geen afstandelijke, objectieve waamemer kan zijn (Capra, 1988:18). Eerder is hij 'deelnemer'.

${ }^{14}$ Zoals cerder opgemerkt spreken Prakash en Rappaport in dit verband van 'information inductance' (1977:37-38).
} 
2 Management accounting: verkenning van een vakgebied

"If the accountant were to serve only a single master, such things as subjectivity or biasedness of information will not be a problem insofar as it generates a profitable result to the decision-maker" (Ijiri, 1982:40).

Omdat het in triple-entry en momentum accounting gaat om zowel het administreren van gerealiseerde als van verwachte effecten van gedane transacties en gebeurtenissen die hebben plaatsgevonden, kan in een dergelijk informatiesysteem de nodige subjectiviteit voorkomen. A la Izeboud zou ik in dit verband willen spreken van 'ondernemend rapporteren' (1992:36) ${ }^{15}$. Dit bemoeilijkt de controleerbaarheid. Maar in een decisionapproach benadering is het tegenargument van 'niet-kwantificeerbaar dan met de nodige subjectiviteit' niet of in elk geval minder valide ${ }^{16}$. Wat is er tegen wanneer een controller/intern accountant een manager die voor een belangrijke beslissing staat, voorziet van gegevens die niet volledig objectief zijn? Sterker nog, het zijn vaak déze gegevens die de meeste beslissingsrelevantie bezitten omdat het kwantitatieve gegevens betreft over in eerste instantie niét-financiële (kwalitatieve) zaken.

"Beyond disconnecting several of the dysfunctional measures currently computed and reported by traditional standard-cost systems, new measures, primarily nonfinancial, will need to become part of the periodic reports for motivation, control, and performance measurement" (Kaplan, 1989:378).

In hun ophefmakende boek 'In Search of Excellence' (het meest verkochte managementboek aller tijden) kwamen Peters en Waterman - ironisch genoeg - tot een soortgelijke conclusie. De bedrijven die de meest nauwkeurig gekwantificeerde financiële doelstellingen nastreefden, deden het financieel slechter dan de bedrijven met meer brede, minder nauwkeurige en meer kwalitatieve doelstellingen (Peters en Waterman, 1982:281) ${ }^{17}$.

Ook in de discussie in de Verenigde Staten inzake de ontwikkeling van 'mark-to-market' accounting in de externe berichtgeving worden tegenargumenten ingebracht als 'subjectief' en 'manipuleerbaar'. Bij 'mark-to-market' accounting (ook 'market value' accoun-

\footnotetext{
${ }^{15}$ Het boekhouden heeft in de loop van de tijd toch al zo veel van zijn spanwijdte verloren, onder andere door het 'afstaan' van waarderings- en verslagleggingsvraagstukken aan de accounting en het systeemontwerp aan de administratieve organisatie (respectievelijk bestuurlijke informatiekunde). Wat over is gebleven, is het registratieve gebeuren.

${ }^{16}$ De discussie omtrent de kwantificeerbaarheid stamt al uit de tjü van de beroernde sterrenkundige Galilei (1564 1642). Hij zei: "Wat niet gemeten kan worden, is niet wetenschappelijk". Mensen legden dit later uit als: "Wat niet kan worden gekwantificeerd, bestaat niet". Vele andere belangrijke waarden zoals ethisch gevoel, kwaliteit en bewustzijn moesten hiermee het veld nuimen wardoor een dode wereld achterbleef (Capra, 1988:123).
}

${ }^{17}$ Overigens zij hiermee opgemerkt dat het net déze bedrijven waren, waar onder IBM, die vervolgens in financiële moeilijkheden geraakten. 
ting of 'fair value' accounting genoemd) worden de activa, met name de financiële activa, zoveel mogelijk gewaardeerd tegen actuele waarde.

"...market values would have to be estimated... The subjectivity inherent in such procedures would reduce ... comparability... and render it difficult to verify valuations... Such reliability problems would make financial statements more prone to manipulation... Although it is possible that reasonably specific standards could be developed to provide the basis for appropriate accounting and auditing practices in this area, such a process is likely to require. considerable time" (U.S. Treasury, 1991).

Maar het gaat hier om waarderingsvraagstukken in de externe berichtgeving. In de interne berichtgeving ligt dit soms geheel anders, of zoals Bromwich zich uitdrukt:

"Management accounting should not be too concerned with objectivity" (1988:26).

In het algemeen kan men de vraag stellen waarom accountants in deze turbulente tijd nog steeds vasthouden aan calculaties met een precisie van 3 cijfers achter de komma zoals die voor standaard-produktieprocessen kunnen worden uitgevoerd. Of zo als Kaplan het uitdrukt:

"Executives of multiproduct companies will be fortunate if the first digit in their product cost estimate is valid, and they can make a reasonably good guess at the second" (1988:64).

In dit triple-entry en momentum accountingonderzoek worden de effecten bestudeerd welke een drie-dimensionale administratie kan hebben op de kwaliteit van management accountingsystemen. Als 'model van de onderneming' wordt het agency-paradigma gehanteerd. Voor zover de invloed van een drie-dimensionale gegevensvastlegging wordt geanalyseerd in het kader van de 'decision approach to accounting' 18 , worden accountinggegevens beschouwd, analoog aan de information-economics approach, als een produkt dat zijn vraag- en aanbodzijdes kent. Wanneer wordt verondersteld dat op basis van een drie-dimensionaal en momentum accountingsysteem de kwaliteit van de beslissingen kan toenemen en derhalve de relevantie in management accountingsystemen (enigermate) kan worden teruggebracht, is het in principe van belang aan te geven op welke wijze individuen gegevens (kunnen) verwerken en (eventueel daarop gebaseerd) beslissingen nemen. Wat dit aspect betreft kan goed worden gebruik gemaakt van de in de psychologie opgedane ervaringen over wat wordt genoemd 'human information processing' (afgekort HIP). Algemeen worden in een HIP-model drie hoofdcomponenten onderscheiden: inputs, processen en outputs. Newell en Simon (1972) hebben op basis hiervan een model

\footnotetext{
${ }^{18}$ Anders gezegd, is het aannemelijk te maken dat op basis van een drie-dimensionale administratie kwalitatief betere beslissingen kunnen worden genomen?
} 
ontwikkeld waarbij zij het cognitieve proces vergelijken met de werking van een computersysteem $^{19}$. Via invoerorganen (oog, oor, neus) wordt de aandacht van een individu gericht op bepaalde zaken in zijn omgeving. In de hersenen (de centrale verwerkingseenheid) worden gegevens over die zaken verwerkt. Vervolgens worden deze gegevens opgeslagen in het geheugen waarbij een onderscheid kan worden gemaakt tussen een intern korte-termijn en intern lange-termijn geheugen en een extern geheugen (zoals aantekeningen). Vervolgens vindt er reflectie op de omgeving plaats via bepaalde uitvoerorganen (zoals mond, handen, voeten). Ahituv en Neumann vatten enkele voor het ontwerp van effectieve informatiesystemen van belang zijnde conclusies uit het HIPonderzoek als volgt samen:

"(1) important data should he emphasized, (2) some redundancy is useful for successful perception, (3) familiar context facilitates perception, (4) too much information will not be absorbed, (5) accessibility to raw data increases users' confidence, (6) people are reluctant to process data manually and therefore any process that can be performed by the computer should be, (7) statistical results should be explicitly displayed and not left to intuition, (8) feedback is vital, and (9) old data should be handled cautiously" (1986:33).

In het onderhavige triple-entry en momentum accountingonderzoek zijn het gegevensverwerkings- en het besluitvormingsproces als een black-box behandeld. Voor het bepalen van de informatiewaarde van het drie-dimensionale accountingsysteem is als surrogaat genomen de verandering in de kwaliteit van het functioneren van de informatiegebruiker. Hierbij kan worden gedacht aan aspecten als gerealiseerd winstniveau, reactietijd of precisie van de handeling. Deze benadering steunt op de gedachte dat 1) gegevens de besluitvorming ondersteunen, 2) besluiten tot acties leiden en 3 ) acties tot resultaten leiden. De black box wordt nu gevoed met een aantal beheerste gegevens-inputs en vervolgens wordt de output gemeten, zijnde de door de informatiegebruiker bereikte resultaten. De aldus af te leiden informatiewaarde wordt wel genoemd 'realistic or revealed value of information'.

"There is no doubt that the realistic value is a good measure because it takes into account human factors related to the perception and preferences as well as the technical characteristics of the information system. As a matter of fact, the normative approach is sometimes criticized because of its fundamental premise that human beings are fully rational and wish so optimize. The realistic value adheres to the satisficing idea because it reflects the performance that is actually attained rather than the one that should be attained" (Ahituv en Neumann, 1986:52).

${ }^{19}$ Dit model is oorspronkelijk ontwikkeld ten behoeve van het onderzoek naar kunstrnatige intelligentie. 
Een dergelijke strategie is reeds in vele invloedrijke laboratorium-onderzoeken toegepast, zoals door Mock (1969), Hedberg (1973) en Edstrom (1973).

Voor zover in dit onderzoek de effecten van triple-entry en momentum accounting worden geanalyseerd in het kader van de 'accountability approach to accounting', wordt hierbij expliciet het cyclisch effect zoals dat volgt uit deze benadering meegenomen: (1) het accountingsysteem meet het gedrag van agenten in organisaties, (2) agenten passen hun gedrag aan omdat zij weten dat dit gedrag wordt beoordeeld op basis van de resultaten uit het accountingsysteem, (3) vanwege de a priori gedragsaanpassing meet het accountingsysteem ander gedrag dan wanneer zo'n systeem niet zou bestaan, (4) het accountingsysteem meet het aangepast gedrag van agenten in organisaties, enzovoort.

Om tot een zo effectief en efficiënt mogelijke bedrijfsbeheersing te kunnen komen, is het de taak van de administratieve organisatie rekening te houden met mogelijke disfunctionele gedragsaanpassingen van agenten. Dit aspect van wederzijdse beïnvloeding van accountingsysteem-gegevens en menselijk gedrag wordt gerekend tot het studieveld 'behavioral accounting',

"Behavioral accounting is the interface of accounting and social science. It is concerned with how human behavior influences accounting data and business decisions and with how accounting information effects business decisions and human behavior" (Siegel en Ramanauskas-Marconi, 1989:1).

Dit triple-entry en momentum accountingonderzoek betreft een studie naar de gevolgen van implementatie van een dergelijk systeem op de besluitvorming door agenten ${ }^{21}$. Als zodanig ligt het onderzoek deels op het terrein van de 'behavioral accounting' en kan het als 'gedragswetenschappelijk' worden aangemerkt.

\footnotetext{
${ }^{20}$ Helaas ontbreekt in Nederland het onderdeel 'behavioral accounting' in de meeste opleidingen waar het onderdeel administratieve organisatic een belangrijke plaats inneemt.

${ }^{21}$ Bedoeld is hier 'besluitvorming' in de breedste zin van het woord. De aan een agent via het accountingsysteem verstrekte gegevens beĩnvloeden diens besluitvorming maar bovendien beïnvloedt het bestaan van het accountingsystcem het gedrag van de agent omdat het over diens bereikte resultaten rapportecrt. Illustratief in dit verband is dat er in de praktijk met betrekking tot de regelgrenzen in de budgettering vaak kleinere afwijkingen worden toegestaan voor positieve budgetverschillen dan voor negatieve budgetverschillen. In geval van negatieve budgetverschillen rekent het management er op dat het betreffende bedrijfsonderdeel zelf spoedig tot cen comigerende actie komt.
} 


\subsection{Samenvatting}

Management accounting is een wezenlijk onderdeel van het management controlsysteem. Dit management controlsysteem is gericht op het op een dusdanige wijze coördineren van de diverse bedrijfsactiviteiten, dat de in de bedrijfsstrategie vastgelegde doelstellingen zo goed mogelijk worden bereikt. In dit verband dient de management accounting en control het gedrag van de mensen in de organisatie te sturen en te motiveren opdat dit leidt tot realisatie van de bedrijfsdoelstellingen.

Het agency-paradigma ziet een onderneming als een netwerk van overeenkomsten tussen partijen. Omdat iedere partij er eigen doelstellingen op na houdt, dient convergentie met de bedrijfsdoelstelling(en) plaats te vinden. Dit gebeurt door het afsluiten van contracten, zoals een budget-overeenkomst. Het accountingsysteem rapporteert over de wijze waarop de partijen de contracten zijn nagekomen. Omdat partijen weten dat over hun gedrag verslag wordt uitgebracht, wordt hun gedrag vaak a priori beïnvloed (een soort 'spelgedrag' zoals dat bij een schaakpartij gebruikelijk is). Het zijn deze (mogelijke) interacties tussen het accountingsysteem en zijn omgeving waarvan de accountant op de hoogte dient te zijn. Dergelijke gedragsmatige aspecten van accounting kunnen de effectiviteit van de technische (getalsmatige) opzet van het accountingsysteem, in belangrijke mate beïnvloeden. 


\section{Hoofdlijnen van de geschiedenis van (manage- ment) accounting}

"Those who do not remember their past are condemned to re-live it" (Santayana in Edwards, 1987:5).

\subsection{Inleiding}

Triple-entry en momentum accounting zijn feitelijk een logische voortzetting van de ontwikkeling van enkel naar dubbel boekhouden. Een historische analyse van deze laatste ontwikkeling is dan ook van belang zodat triple-entry en momentum accounting tegen een historische achtergrond kunnen worden belicht. De huidige toegepaste accountingmethoden en -technieken zijn niet het progressieve, maar meer het geleidelijke cumulatieve resultaat van inteme en externe krachten die hun invloed op organisaties hebben doen gelden (aldus evolueert accounting analoog aan de ideeën van Darwin). Om deze reden is het voor accounting-onderzoekers van belang dat zij hun werk doen in een constant historisch perspectief, zodat zicht bestaat op de problemen die voorgangers bezig hielden (Bricker, 1991:73). Met name zal de belangstelling voor historisch onderzoek toenemen wanneer een vakgebied significante transformaties ondergaat, onder druk staat of zich in een crisis bevindt (Miller, Hopper en Laughlin, 1991:395). Voor management accounting kan worden gesteld dat dit laatste opgaat (zie hoofdstuk 4).

Niet iedereen onderkent het belang van historisch onderzoek. Zo omschreef Napoleon geschiedenis als 'een aantal leugens waarover men het eens is geworden'. In elk geval kan met het in dit hoofdstuk opgenomen historisch overzicht worden vastgesteld, dat accounting rationeel kan worden bedreven met zeer beperkte middelen. Iets dat men in de praktijk van dit automatiserings-tijdperk wel eens wil vergeten en wat (helaas) enkel boekhouden in vele opleidingsprogramma's het 'leven' heeft doen kosten.

Het beschrijven van de geschiedenis van management accounting betekent voor een belangrijk deel het beschrijven van de geschiedenis van het boekhouden. Ooit was accounting niet veel meer dan dubbel boekhouden.

De bedriffseconomie heeft als bakermat het boekhouden. De uit het boekhouden ontstune bedrijfsleer is in de jaren ' 20 en ' 30 van deze eeuw getransformeerd in de bedrijfseconomie (Bosman, 1984:199).

Overigens is de bedrijfseconomie in ons land niet ontstaan als een afsplitsing van de 
algemene economie, maar veeleer als een reactie op een in de praktijk gevoelde behoefte (Schreuder, 1985:4). Grofweg kan men stellen dat er twee soorten strategieën zijn gevolgd bij het ontwikkelen van de bedrijfseconomie. Enerzijds is dit de praktijkgeoriënteerde bedrijfskundige benadering van de 'Rotterdamse school', anderzijds is dit de economisch-theoretische normatieve benadering welke door de 'Amsterdamse school' (Limperg) werd gepropageerd.

\subsection{Hoofdlijnen van de geschiedenis van het boekhouden}

\subsubsection{Periode van het enkel boekhouden}

Het boekhouden zoals zich dat ontwikkelt in de periode 4000-3000 v. Chr. is een hoeveelheidsadministratie. Het aantal slaven, het aantal stuks vee, dadels, kruiken wijn, broden zijn voorbeelden van te administreren 'objecten' uit die tijd ${ }^{l}$. Men maakt gebruik van klei-tabletten, stokken, touwen ${ }^{2}$, en dergelijke om gegevens vast te leggen. In deze periode valt de ontwikkeling van beelden ${ }^{3}$ naar symbolen, naar getallen en uiteindelijk naar het geschreven woord waar te nemen.

Het begin van het boekhouden ligt ongeveer gelijk met de ontwikkeling van de kunst van het schrijven waarvan de eerste beginselen zo'n 3000 jaar v. Chr. in Irak zijn ontstaan (Walker, 1987:2). Het is waarschijnlijk dat het schrijven aanvankelijk slechts tot doel had het kunnen vastleggen van economische transacties. Van de oudste klei-tabletten die zijn gevonden, zijn dan ook $85 \%$ economische overzichten.

Het gebruik van geld als ruilmiddel wordt voor het eerst zo'n 700 jaar v. Chr. in Lydië waargenomen. Dit geeft voor het boekhouden nieuwe mogelijkheden omdat thans de diverse bezittingen bij elkaar kunnen worden opgeteld zodat iemands 'rijkdom' kan worden bepaald (onder andere van belang voor de te betalen belasting). Een fraai voorbeeld van het gebruik van geld in een enkelvoudige boekhouding betreft de verantwoording van de bouwkosten van het Parthenon. Deze tempel werd in $447 \mathrm{v}$. Chr. gebouwd voor Pallas Athene, lievelingsdochter van Zeus en beschermvrouwe van de

\footnotetext{
'Het wordt 'kapital' is afgeleid van het Latijnse woord 'Caput' wat 'hoofd' betckent. Vroeger werd icmands rijkdom bepaald door het tellen van de hoofden van het vee.

${ }^{2}$ Het oudste touw ('quipo') zoals dat in Peru en cok in China werd gebruikt, is gevonden op Hawaï. In zo'n touw, van soms een kilometer lang, werden knopen gelegd om bijvoorbeeld aan te geven hoeveel inwoners een dorp had. Vervolgens werd aan het touw cen tweede touw vastgemaakt waarvan het aantal knopen bijvoorbceld aangaf hoeveel vrouwelijke inwoners er waren, het aantal knopen in een derde touw gaf aan hoeveel vrouwen ongehuwd waren, enzovoort. Met andere woorden: hier werd reeds een fraaie vorm van bestandsorganisatic toegepast.

${ }^{3}$ In het spijkerschrift ('cuneiform') gaf men kasuitgaven weer door twee benen, afgebeeld in looppas. Hiermee drukte men uit dat 'er iets van door ging' (Stevelinck, 1985:14).
} 
Grieken. De uitgaven zijn in een marmeren steen gebeiteld en voor een ieder 'ter inzage' bevestigd op de Acropolis te Athene.

Het gebruik van Arabische getallen (in plaats van Romeinse), wordt voor het eerst in India geconstateerd, circa 250 jaar v. Chr. Hiermee krijgen cijfers van een getal een plaatswaarde, dat wil zeggen, de plaats van een cijfer in een getal bepaalt de waarde van het cijfer. Wil men van deze eigenschap bij het rekenen gebruik maken, bijvoorbeeld bij het optellen en aftrekken, dan zullen inkomsten en uitgaven in afzonderlijke reeksen (debet en credit) moeten worden geplaatst. Omstreeks het jaar 1000 hebben de Arabieren hun systeem in Europa (Spanje) geïntroduceerd (Edwards, 1987:47). Maar het heeft uiteindelijk nog vele jaren geduurd voordat het Hindoe-Arabische systeem algemeen werd overgenomen. Het boek van Leonardo Pisano 'Liber Abacci' heeft hierbij een grote rol gespeeld. Pacioli heeft in zijn werken veelvuldig gebruik gemaakt van deze 'nieuwe rekenkunde'.

De uitvinding van papier rond 190 v. Chr. (perkament) wordt in Egypte getraceerd en is van groot belang voor de vastlegging van gegevens.

Referenties naar de mogelijkheden van het gebruik van boekhoudsystemen vinden we terug in vele oude geschriften, onder andere in de Bijbel. Van de Bijbel wordt verondersteld dat deze gebeurtenissen beschrijft die plaatsvonden tussen $1800 \mathrm{v}$. Chr. en $100 \mathrm{n}$. Chr. In Lucas 16:2 vinden we een frase over het afleggen van rekening en verantwoording:

"Wat hoor ik daar van u? Geef rekenschap van uw beheer want gij kunt niet langer rentmeester blijven" (Katholieke Bijbelstichting, 1985:1369).

De verwijzing naar het belang van kasstroomprojectie (budgettering) in Lucas 14:28 is al even evident:

"Als iemand van $u$ een toren wil bouwen, zal hij er dan niet eerst voor gaan zitten om een begroting te maken of hij wel genoeg bezit om hem te. voltooien?" (Katholieke Bijbelstichting. 1985:1367).

Ondanks het vrij negatieve mensbeeld dat in de Bijbel heerst ('vertrouw noch buur noch vriend') kunnen we passages vinden die betrekking hebben op het betrekken van de knechten bij bijvoorbeeld de budgettering. In Spreuken 15:22 lezen we:

"Waar geen overleg is falen de plannen, maar zij slagen als er veel raadgevers zijn" (Katholieke Bijbelstichting, 1985:821). 
Men kan deze spreuk uitleggen als een pleidooi voor participatieve budgettering. Ook kunnen in de Bijbel verwijzingen worden teruggevonden naar controles op het werk van knechten. In Matteüs 24:46 vinden we, als het gaat om het aan de knechten opgedragen werk, een verwijzing naar een 'surprise audit':

"Gelukkig die knecht als de heer bij zijn komst hem daarmee bezig vindt" (Katholieke Bijbelstichting, 1985:1309).

De functies van het boekhouden die uit de referenties in de Bijbel spreken betreffen met name (1) het reduceren van fraude, (2) het reduceren van conflicten tussen partijen en (3) het controleren van gedelegeerde taken ${ }^{4}$.

Ook de uitvinding van de boekdrukkunst door Gutenberg in 1450 is van groot belang geweest voor de ontwikkeling en verspreiding van de kennis van het boekhouden.

\subsubsection{Periode van het dubbel boekhouden; ontwikkelingen in Italië}

De oudste nog beschikbare overzichten waarin de karakteristieken van het dubbel boekhouden volledig zijn terug te vinden, stammen uit 1340 en zijn de Massari rekeningen van de stad Genua (Chatfield, 1977:35). Massari waren gemeentelijke ambtenaren belast met het financieel beheer en de gemeentelijke boekhouding van de stad.

Algemeen wordt Pacioli's boek 'Summa de Arithmetica et de Proportione et Proportionalita' (gedateerd 20 november 1494) beschouwd als het oudste gedrukte boek waarin wordt verhandeld over het (dubbel) boekhouden. En met de introductie van het dubbel boekhouden wordt volgens sommige accountants tevens 'wetenschappelijkheid' in het boekhouden ingebracht (Eldrigdge, 1930:6).

De Summa, half geschreven in het Toscaans en half in het Venitiaans, telt 210 bladzijden en de tekst is verdeeld in 5 delen: 1 . Rekenkunde en algebra, 2. De toepassing van de rekenkunde en algebra bij het handelsrekenen, 3. Boekhouden, 4. Geld en geldhandel en 5. Zuivere en toegepaste meetkunde. Deel 3 uit de Summa dat handelt over boekhouden, 'Computis et Scripturis', beslaat 36 korte hoofdstukken.

De typische kenmerken van de methode van dubbel boekhouden zoals door Pacioli

\footnotetext{
4 Ook ten aanzien van de Islam (de 'godsdienst van de handelaren') kunnen inceressante aspecten van het (dubbel) boekhouden worden teruggevonden. Dit is niet zo verwonderlijk omdat in die tijd Mecca een belangrijk handelscentrum was. Hamid et al (1993:1-20) beweren dat de administratie van het Moslim-hoofdkantoor zoals die in de 10e eeuw werd gevoerd, belangrijke kenmerken van het dubbel boekhouden vertoonde en in elk geval heeft bijgedragen aan de ontwikkeling daarvan.
} 
beschreven, wel 'de Italiaanse methode' of de 'methode van Venetië' genoemd, zijn (gebaseerd op ten Have, 1973:50):

a) Het gebruik van slechts 3 boeken, 2 dagboeken, memoriaal en journaal en een grootboek.

b) De afsluiting is naar keuze als de boeken vol zijn of eerder.

c) Voor elke transactie (lees: avontuur ter zee) wordt een aparte rekening bijgehouden ('venture account') die pas wordt afgesloten wanneer de gehele transactie is beëindigd. Dit is een vorm van project-administratie.

d) Grootboekrekeningen bestaan uit twee tegenover elkaar liggende bladzijden.

De naam 'grootboek' is ontstaan omdat dit het grootste en meestal fraaist gebonden boek was dat men gebruikte.

Bij Pacioli ligt het zwaartepunt van de administratie in het grootboek. Dagboeken, het memoriaal en het journaal waren slechts hulpmiddelen voor het opmaken van het grootboek. Na verwerking in het grootboek werden deze boekingen dan ook doorgestreept. Het zijn de Hollanders geweest die het zwaartepunt van het grootboek hebben verlegd naar de eerste vastleggingen in dagboeken. Via deze 'Hollandse methode van boekhouden' werden transacties direct bij het ontstaan gesorteerd naar de effecten op de diverse posten in het grootboek.

Pacioli, van nature een wiskundige, heeft nog een 'meesterwerk' gepubliceerd. Zijn tweede hoofdwerk 'Divina Proportione' schreef Pacioli tezamen met zijn vriend Leonardo da Vinci. In dit boek beschrijven zij met name de vaste verhoudingen zoals men die in de natuur kan aantreffen, maar ook in bijvoorbeeld de accounting. Het visueel uitbeelden van getalsmatige verhoudingen is hiervan een uitwerking.

Alhoewel tegenwoordig vrijwel iedereen spreekt van 'Pacioli' is er nogal wat discussie geweest over de juiste familienaam van 'Fratris Luce': Paciolus, Paciolo of Pacioli (de Roover, 1943:68). Op een gedenkplaat in zijn geboorteplaats Borgo San Sepolcro staat (Taylor, 1943:74):

\section{'A Luca Pacioli}

Che ebbero amico e consultore Leonardo da Vinci'. Enzovoort.

Hier wordt dus 'Pacioli' ${ }^{5}$ gebruikt. Wanneer de voorkeur wordt gegeven aan de Latijnse spelling, dan is 'Lucas Paciolus' correct. De Italiaanse vertaling hiervan is 'Paciolo'. Pacioli is een afkorting van 'dei Pacioli' wat zoveel betekent als 'van de Paciolo's' (Taylor, 1943:69).

\footnotetext{
${ }^{5}$ Uit te sprekcn als 'Pah-chàw-li' (de Roover, 1943:69).
} 
Of de Summa inderdaad een origineel werkstuk is van Pacioli, wordt nogal eens in twijfel getrokken. Onder andere Vasari beschuldigt Pacioli van plagiaat. Volgens Vasari zou Pacioli de meeste van onder zijn naam gepubliceerde geschriften zich van zijn leraar Piero della Francesca hebben toegeëigend (Yamey, 1989:130). Ook Troilo de Cancellaris, een rekenmeester uit Venetië, wordt genoemd als de oorspronkelijke schrijver van het manuscript van het hoofdstuk over 'dubbel boekhouden' in de Summa en dat Pacioli vrijwel onbewerkt zou hebben overgenomen (Yamey, 1989:132).

Pacioli geeft zelf in de Summa aan dat hij niet origineel is in zijn werk, maar de praktijk van het boekhouden beschrijft zoals die al jaren in Venetië werd beoefend. In ieder geval kan men stellen dat de Summa van Pacioli het eerste gedrukte werk is dat handelt over dubbel boekhouden. Het manuscript van Cotrugli 'Delia Mercatura et del Mercante Perfetto', ook handelend over de beginselen van het dubbel boekhouden, was in elk geval eerder gereed (in 1458) maar werd pas in 1573 gepubliceerd.

Pacioli kende het manuscript van Cotrugli en hij schreef de 'uitvinding' van dubbel boekhouden dan ook toe aan Cotrugli (Chatfield, 1977:50). Overigens is Cotrugli's aanbeveling voor de handelaar met betrekking tot het afsluiten van de boeken, opvallend: 'Sluit de boeken om de 7 jaar af, neem dan een jaar rust om vervolgens de draad weer op te pakken'6.

Er bestaat ook nog een veronderstelling dat een Benediktijner monnik uit het klooster van de heilige Martinus del Scole te Palermo, Angelo Senesio, in 1348 de uitvinding zou hebben gedaan (ten Have, 1973:19).

Pacioli wordt verweten dat hij een onvolledige beschrijving geeft van de heersende praktijk van toen. Pacioli heeft het in de Summa in het geheel niet over subgrootboeken, reserves, over controlerende tussenrekeningen, accruals, over cost accounting noch over bijvoorbeeld controle van de jaarstukken. Toch waren dergelijke zaken in die tijd al in bepaalde mate gemeengoed (Chatfield, 1977:42). Maar kennelijk wilde Pacioli zijn leerboek niet te ingewikkeld maken. Hij deed daarom ook zijn uiterste best om negatieve getallen zoveel mogelijk te vermijden en het bestaan van twee pagina's (kolommen) is hier mede op terug te voeren ${ }^{7}$. Het werken met negatieve getallen was een voor die tijd vrij nieuw concept in Europa (Scorgie, 1991:78) ${ }^{8,9}$.

\footnotetext{
${ }^{6}$ Het getal 7 vinden we vaak terug in vroegere geschriften. Waarschijnlijk heeft dit te maken met de 'drievoudigheid' zoals die in hoofdstuk 1 is beschreven. Drie basisvariabelen -zeg X, Y en $Z$ - kunnen zich in 4 verschillende combinaties manifesteren waarin geen van de drie oorspronkelijke variabelen wordt herhaald. Dit (lagere) viervoud $(\mathrm{XY}, \mathrm{XZ}, \mathrm{YZ}$ en $\mathrm{XYZ}$ ) tezamen met het drievoud geeft zeven. Zo onderscheidt men bij een mens ook 7 stadia van bewustzijn en 7 chakra's.

'De kerk bestempelde in die tijd negatieve getallen als 'ketters' (Parkinson, 1987:22) en dit zal zeker ook de houding yan Pacioli hebben beïnvloed.

${ }^{8}$ Latere grote geleerden als Descartes (1596-1650) en Pascal (1623-1662) zagen het nut niet in van negatieve getallen en noemden ze 'false roots' en 'utter nonsense' (Ijiri, 1982:6).
} 
In zijn geboorteplaats Borgo San Sepolcro is voor Pacioli een gedenkplaat opgericht. De volledige tekst van deze gedenkplaat is als volgt door Taylor (1943:74) vertaald:

\section{To Luca Pacioli}

Who was friend and counselor to

Leonardo da Vinci

and Leon Battista Alberti

and who first gave to Algebra

the voice and structure of a Science.

$\mathrm{He}$ was the great founder

of its application to Geometry

He invented the double entry system

He wrote works on mathematics

which became the foundation and

unvaried form for future thinking

The people of San Sepolcro

at the instance

of their Workers' Society

putting to shame 370 years of neglect

to its great fellow citizen

Erected

1878

Over het jaar van overlijden van Pacioli bestaat geen volledige zekerheid. Zo stelt Nakanishi (1979:53) dat Pacioli op 19 juni 1517 is overleden en niet in 1515 zoals onder andere Yamey (1989) stelt. Nakanishi baseert zich hierbij op het dodenboek (necrologium) van 19 juni van de broeders Franciscanen.

\subsubsection{De ontwikkeling van het dubbel boekhouden in andere landen}

Als eerste Nederlandstalige werk over het dubbel boekhouden wordt beschouwd 'Nieuwe Instructie ende bewijs der looffelijcker consten des rekenboecks' (Antwerpen, 1543) van de Vlaming Jan Ympyn Christoffels ${ }^{10,11}$. Dit boek, dat voor een groot deel een be-

\footnotetext{
${ }^{9}$ De Chinezen gebruikten negatieve getallen al veel langer op hun 'abacus'. Positieve getallen hadden een rode kleur en negatieve getallen hadden een zwarte kleur.

${ }^{10}$ Abusievelijk meldt ten Have op pagina 54 dat dit boek in 1553 is uitgegeven. Op pagina 69 wordt 1543 als jaartal opgegeven (ten Have, 1973:54-69). Ympijn is dan reeds overleden en het manuscript wordt door zijn echtgenote gepubliceerd.
} 
schrijving is van de Italiaanse wijze van boekhouden, werd zowel in het Frans als in het Engels vertaald. Ympijn maakte als eerste gebruik van een proefbalans voor het controleren van het evenwicht in de boekhouding (Epstein, 1990:4). Bovendien voerde hij als eerste grootboekrekeningen voor balansposten in (Pacioli kende dit type rekeningen niet). Aan het internationaal verspreiden van de kennis van de methode van het dubbel bockhouden heeft de Nederlander Simon Stevin (1548-1620), vertrouwensman en administrateur van Prins Maurits, een belangrijke bijdrage geleverd. Hij heeft behalve een aantal wiskundige boeken (waar onder 'Wisconstige gedachtenissen') ook belangrijke werken over het boekhouden gepubliceerd. Het meest bekende boekhoudkundige werk van Stevin is wel 'Vorstelicke bouckhouding op de Italiaensche wyse in domeine en finance extraordinaire' uit 1607 en uitgegeven bij Jan Bouwensz te Leiden ${ }^{12}$. Drie jaar eerder publiceerde hij 'Verrechting van Domeinen, ende vorstelyke Bouckhouden' (Amsterdam, 1604).

Het werk van Stevin wordt in Engeland door Richard Dafforne, de stuwende kracht achter de ontwikkeling van het dubbel boekhouden in Engeland (met name via zijn boek 'The Merchants Mirror', 1636) ${ }^{13}$, bewerkt en verspreid. Volgens Van Geijsbeek deed Dafforne dit echter niet op treffende wijze omdat hij belangrijke ideeën van Stevin onvertaald liet (Epstein, 1990:7).

Stevin beval de methode van dubbel boekhouden ook aan voor de overheidsadministratie hetgeen in Amsterdam, maar ook in vele buitenlandse steden werd opgevolgd. Hierbij werden de boeken van een bepaald belastingjaar opengehouden totdat de belasting voor dat jaar voor het grootste gedeelte was geïnd.

Voor de ontwikkeling van het boekhouden in Amerika wordt Stevin een belangrijker plaats toebedacht dan Pacioli (Epstein, 1990:7). Met name de Hollandse vestiging aldaar in New Amsterdam (New York) heeft hierin een rol gespeeld. Epstein baseert zijn conclusie op het feit dat, zoals bij Stevin en Dafforne, in de eerste boekhoudkundige werken in koloniaal Amerika geen religieuze verwijzingen zijn opgenomen. Boven grootboekrekeningen plaatste Pacioli gewoonlijk een kruis als referentie aan God. Dit zou falsificatie van boekhoudkundige gegevens moeten tegengaan. Ook werd het aantal van 13 posten of rekeningen regelmatig gebruikt (= aantal apostelen).

\footnotetext{
"In het voorwoord van zijn boek 'Practicque om te leeren rekenen cypheren ende boeckhouwen' (Amsterdam, 1583) claimt Pietersz dat dit het eerste boekhoulbock is van ecn Nederlander (Yamey, 1980:82). Yamey suggereert dat dit Stevin moet zijn. Echter, Srevin is een in het Nederlands schrijvende Vlaming.

${ }^{12}$ Over het precieze jaaral van deze publikatie het volgende. Scorgie verwijt Worthington dat deze aanneemt dat dit rond 1544 was. Volgens Scorgie kan Stevin onmogelijk de publikatie in 1544 hebben gehad. "That is about four years before Stevin was born in Bruges" (Scorgie, 1991:80).

${ }^{13}$ Het eerste boek in Engeland dat handelde over het dubbel boekhouden is van Oldcastle (1543). Dit was cen vrijwel letterlijke vertaling van de Summa van Pacioli.
} 
Uit Duitsland is het manuscript van Schwarz uit 1518 vermeldenswaard, hetwelk als het eerste gedrukte werk na de Summa wordt beschouwd. Schwarz was boekhouder bij de Fuggers, een rijke handelaarsfamilie uit Augsburg met vele vestigingen op evenzovele lokaties. Hij ontwikkelde een geïntegreerd boekhoudsysteem (een methode voor filiaalconsolidatie) en legde de grondslagen voor 'profit-center accounting' (Inoue, 1982:39). 'Threefold' bij Schwarz betekent het volgende:

1) Voor transacties in de periode 1 januari-30 september de Italiaanse methode toepassen;

2) Voor transacties in de periode na 30 september tot 31 december de Duitse methode toepassen (deze methode werd gekenmerkt door het gebruik van een gesplitst grootboek, een deel voor goederen en een deel voor schuldverhoudingen);

3) Het samenstellen van geconsolideerde jaaroverzichten per het einde van het jaar.

Het eerste Amerikaanse boek waarin een hoofdstuk over dubbel boekhouden is opgenomen, is 'Young Man's Companion' (1737). De auteur van dit werk is onbekend.

\subsubsection{Alternatieve interpretatie van de ontwikkeling van het dubbel boekhouden}

Stevin merkt in een van zijn boeken op dat een van zijn vrienden, een historicus, na het doorlezen van zijn manuscript beweerde dat eenzelfde of in elk geval een zeer goed vergelijkbare vorm van het door hem beschreven dubbel boekhouden reeds gangbaar was in de tijd van Julius Caesar (110-44 v. Chr.). Dit is een eerste aanwijzing dat het dubbel boekhouden reeds lang voor Pacioli in gebruik was.

Wanneer, zoals algemeen wordt aangenomen, de ontwikkeling van het boekhouden parallel is opgelopen met de ontwikkeling van de handel, ligt het voor de hand de bron van boekhouden daar te zoeken waar voor het eerst handel bloeide. De eerste handelaren waren de Arabieren die vervolgens de Egyptenaren de eerste beginselen van het handeldrijven leerden (Yamey, 1980:84). De bekende oriëntalist Alexander Hamilton stelt dat Venetië, zijnde de handelspoort van Europa van destijds, de methode van het dubbel boekhouden moet hebben geïmporteerd van de handeldrijvende Hindoes uit India.

"We would remark that the Banians of India have been, from time immemorial, in possession of the method of book-keeping by double-entry ..." (Hamilton in Yamey, 1980:87).

Met name in India zou het Bahi-khata systeem, een op dubbel boekhouden geënt systeem, al vele eeuwen zijn gebruikt. 
'The Bahi-khata is a double-entry system of bookkeeping that predates the 'Italian' method by many centuries' (Lall Nigam, 1986:148).

Het Bahi-khata ${ }^{14}$ systeem wordt vandaag de dag nog in India toegepast en heet 'Bahikhata, Mahajanor Deshi-Name'. De ontwikkeling van het systeem ligt in de periode 200 voor en 200 na Chr. Het traditionele systeem van onderwijzen in India, kennisoverdracht van mond tot mond, zou er toe hebben bijgedragen dat de kennis van het Bahi-Khata systeem lang tot slechts enkele volkeren is beperkt gebleven. Het systeem, waarbinnen een gedetailleerde resultatenrekening werd opgemaakt, is voor die tijd zeer geavanceerd te noemen. Diverse dagboeken en subgrootboeken waren in gebruik zoals ook, bij kleinere ondernemingen, gemengde grootboekrekeningen. Voor inkopen en verkopen hield men soms aparte dagboeken bij, maar het was niet ongewoon om deze in het kasboek op te nemen $^{15}$ zodat ze niet in de vergetelheid zouden geraken. Elke dag werd met een nieuwe pagina begonnen waarop de transacties van die dag werden geregistreerd. Boven de datum werd bovendien een verwijzing opgenomen naar de een of andere favoriete yogi. Vergelijkbare opschriften, zoals bijvoorbeeld 'in de naam van God en Winst', kwamen later ook bij de Italiaanse methode voor.

Er wordt bij historisch accountingonderzoek nogal eens 'gezondigd' tegen het 'dubbel' van dubbel boekhouden. Het gebruik van debet- en credit-kolommen of enige andere vorm van bilateraliteit zoals het tweemaal invoeren van het bedrag behorend bij elke transactie, betekent nog geenszins het bestaan van een dubbel boekhoudsysteem (Scorgie en Chandran, 1992:96). Debet en credit zijn niet strikt gebonden aan een 'dubbel' boekhoudsysteem. Ook in enkel boekhouden gebruikt(e) men veelvuldig debet- én creditkolommen. De belangrijkste reden hiervoor is vermoedelijk dat men snel over het saldo wil(de) beschikken van personen die zowel als klant en als leverancier fungeerden (Chatfield, 1977 pag. 34) ${ }^{16}$.

\subsubsection{Economische ontwikkeling en boekhouden}

De relatie tussen economische ontwikkeling en ontwikkeling van het boekhouden wordt onder andere door de bekende Duitse econoom en historicus Sombart (1863-1941)

\footnotetext{
14 'Bahi' staat voor 'boekhoudboeken'. In het systeem is debet 'Nam' en credit 'Jama'.

15 Dit gebeurde zowel bij de uitgaven als hij de ontvangsten zodat het administratieve kassaldo nog altijd zou overeenstemmen met het werkelijke kassaldo.

16 In deze zin is 'triple-entry' accounting dan ook misleidend omdat deze naamsaanduiding de procedurele aspecten (het drie keer invoeren van een getal) accentueert. Veel meer dan om een procedurele aanpassing gaat het bij tripleentry accounting om een conceptuele uitbreiding van het alom in de accounting toegepaste dubbel boekhoudmodel.
} 
beschreven. Volgens Sombart zou de geschiedenis bij afwezigheid van dubbel boekhouden een geheel ander verloop hebben gehad.

"Capitalism without double-entry book-keeping is simple inconceivable. They hold together as form and matter. And one may indeed doubt whether capitalism has procured in double-entry book-keeping a tool which activates its forces, or whether double-entry book-keeping has first given rise to capitalism out of its own [i.e. rational and systematic] spirit" (uitspraak van Sombart vertaald door Yamey, 1989:125).

In zijn 'verheerlijking van het boekhouden' gaat Sombart heel ver.

"Die doppelte Buchhaltung ist aus demselben Geiste geboren wie die Systeme Galileis und Newtons, wie die Lehren der modernen Physik und Chemie. Und wird schon - ich möchte sagen - bei rein ästhetischer Bewertung in der Tat die doppelte Buchhaltung nicht ohne Staunen und Bewunderung betrachten können als eines der kunstvollsten Gebilde des wunderreichen Gestaltungs-vermögens der europäischen Menschheit" (uitspraken van Sombart, opgenomen door Lister, 1985:229-230).

Yamey bestrijdt overigens de stelling van Sombart ${ }^{17}$ en vindt dat deze ver overdrijft. De meest perfecte boekhouding maakt immers van iemand nog geen bekwaam handelsman. Lister stelt dat Sombart het boekhouden wel degelijk voldoende kritisch tegemoet trad. Bepaalde zinsneden van Sombart zouden uit hun verband zijn gerukt en bovendien verkeerd zijn vertaald. Sombart zelf wijst in zijn werk 'Der moderne Kapitalismus' regelmatig op de beperkingen van boekhoudkundige systemen (Lister, 1985:229). Maar ook Eucken, Weber en Schumpeter zien in de historie een causale relatie tussen economische ontwikkeling en kennis van het dubbelboekhouden (Edwards, 1987:17). Eucken (1891-1950), een bekend Duits neo-liberaal econoom, verklaart dat de ontwikkeling van Noord-Duitsland pas zo laat op gang is gekomen mede door de onbekendheid met de methode van dubbel boekhouden. En Goethe laat zich in 'Wilhelm Meisters theatralische Sendung' (1773-85) al niet minder positief uit over het dubbel boekhouden.

"Welche Vorieile gewährt die doppelte Buchaltung dem Kaufmanne! Es ist eine der schönsten Erfindungen des menschlichen Geistes".

${ }^{17}$ Ten Have spreekt steeds van Sombard. 
Cayley (1895) spreekt over het boekhouden als:

"... one of the two perfect sciences" (in: Cooper en Kozmetsky, 1992:4).

Ook Elzinga schetst op treffende wijze de relatie tussen economische ontwikkelingen en de stand van het boekhouden.

"Het nauwe verband tussen boekhouden en economische geschiedenis springt voor ieder in het ong, die het boekhouden niet slechts kent als een technisch systeem, doch in zijn verschillende vormen de weerspiegeling ziet der bedriffstechniek van de periode, waarin deze vormen tot ontwikkeling kwamen. De behoeften van het bedrifsleven schiepen immers steeds weer de vormen van het technisch systeem" (Elzinga in Ten Have, 1973:10)

Meer recent in dit verband zijn de uitspraken van Kelly en Spicer met betrekking tot de huidige crisis van de management accounting (zie hoofdstuk 4).

"Cost-accounting is wrecking American business. If we're going to remain competitive, we've got to change our costing systems (Kelly, 1988:18).

Spicer schrijft het verlies aan concurrentiekracht van de Westerse industrie voor een belangrijk deel toe aan het falen van de management accounting (1992:65). In ieder geval is duidelijk dat het boekhouden en in meer brede zin de accounting een belangrijke invloed heeft gehad en nog steeds heeft op economische ontwikkelingen ${ }^{18}$. Het is ook duidelijk dat dit in sommige gevallen als een stimulerende en in andere gevallen als een remmende werking is ervaren.

\subsection{Van bockhouden naar cost accounting}

In 1602 wordt in Nederland de (Verenigde) Oost-Indische Compagnie (V.O.C.) opgericht. Deze organisatie trok risicodragend kapitaal aan in relatief kleine coupures. Iedere 'goklustige' kon meespelen. In plaats van samenwerking voor een bepaalde zeereis ontstond nu samenwerking voor een onbepialde periode en zo werd het 'going concem' geboren. De bescherming van de geldschieters was nog maar zeer beperkt. In het handelsvest (charter) van de V.O.C. was bepaald dat er geregeld elke 10 jaar een 'generale' afsluiting moest komen. In Engeland was het Cromwell die in 1657 het charter van de Londense O.C. veranderde en de verplichting oplegde om elke 7 jaar, daarna elke 3 jaar, de balans op te maken. Deze balansen moesten voor een ieder ter inzage liggen.

\footnotetext{
${ }^{18}$ Ook Gorbatsjov wees op het belang van het ontwikkelen van cen boekhoudcultuur voor zijn economische hervormingen. Hij sprak in dit verband van 'statistici' en 'volledige bedrijfscalculatie' (1987:101).
} 
Dit systeem werd later uitgebouwd doordat de aandeelhouders een deskundige konden benoemen ('auditor') voor het controleren van de overgelegde balansen) ${ }^{19}$. Hieruit is uiteindelijk het (openbare) accountantsberoep geboren.

In Frankrijk wordt voor het eerst in 1673 wettelijk geregeld (in de 'Ordonnance de Commerce') dat bepaalde bedrijven om de twee jaar een balans moeten publiceren waarin de eigendommen worden gespecificeerd.

In 1776 verschijnt het boek van Adam Smith 'An Inquiry into the Nature and Causes of the Wealth of Nations'. Hierin beschrijft Smith hoe door arbeidsverdeling belangrijke efficiency-voordelen kunnen worden behaald. Deze arbeidsverdeling en hiermee gepaard gaande specialisatie doen de behoefte aan coördinatie toenemen. En coördineren is met name een informatieprobleem en zo kunnen bedrijven worden gezien als oplossingen van deze informatieproblemen (Douma en Schreuder, 1992:3,48) ${ }^{20}$. En binnen bedrijven zijn informatieproblemen voor een belangrijk deel op te lossen met behulp van accounting.

Het ontstaan van cost accounting kan worden teruggevoerd tot het begin van de negentiende eeuw ${ }^{21}$. Nog niet gehinderd door wettelijke voorschriften inzake de externe berichtgeving maakt accounting in de periode 1800-1920 een bloeiperiode door. Pas in de jaren hierna is de primaire functie van accounting geworden het voldoen aan de externe publikatievoorschriften (Johnson en Kaplan, 1987:xii).

De accounting heeft zich zoals gezegd pas in het begin van de negentiende eeuw losgemaakt van het boekhouden. In deze periode ontstaan belangrijke waarderingsvraagstukken waarmee de verwerking van financiële gegevens een nieuwe dimensie krijgt. Voordat men gegevens kan vastleggen (de registratie), dienen thans veel meer dan voorheen waarde-oordelen te worden geveld. De 'ontkoppeling' van waardering en registratie had alles te maken met de industriële revolutie en de opkomst van de grote hiërarchische ondernemingen. De afschrijvingsproblematiek doet zijn intrede en met name ook het toerekenen van kosten aan delen van het produktieproces (casu quo afdelingen) wordt van belang in het kader van de bedrijfsbeheersing.

Volgens Littleton is dan ook de cost accounting een produkt van de industriële revolutie

\footnotetext{
19 'Accoum' is afgeleid van het Latijnse woond 'audire' wat staat voor 'luisteren naar'. Vroeger bestond controle met name uit het voor de principaal in de aanwezigheid van getuigen hardop voorlezen van de door de agent bijgehouden stukken (een voor de hand liggende procedure in een gemeenschap waarin men nauwelijks kon schrijven noch lezen). 'Auditor' (controlerend accountant) is hiervan afgeleid. Tot de elfde eeuw werden financiele gegevens bijna steeds mondeling verstrekt en dienen geschreven documenten tot niet meer dan aanvulling (De Vries, 1985:5-6).

${ }^{20}$ Ook de interne structuur van bedrijven, bijvoorbeeld de mate van decentralisatie, wordt in belangrijke mate bepaald door informatie-problemen (Kaplan en Alkinson, 1989:526).

${ }^{21}$ Ook bijgedragen tot de ontwikkeling van accounting in de achttiende en negentiende eeuw heeft de omstandigheid dat het in onderwijsinstellingen gebruikelijk werd de prestaties van studenten in getallen uit te drukken (Hoskin en Macve, 1988:54).
} 
(Littleton, 1933:321). Cost accounting vindt rond 1800 zijn oorsprong. Een verklaring voor het ontstaan van cost accounting in deze periode kan worden gegeven door te refereren aan de transactiekosten-theorie zoals door Williamson (1975) opgesteld. Williamson ziet markten en bedrijven als twee alternatieven voor het coördineren van activiteiten en transacties. Op markten zorgt het prijsmechanisme (beïnvloedt door onderhandelingskrachten) voor de onderlinge coördinatie van vraag en aanbod. In een bedrijf is deze economische coördinatie de taak van het management en vindt deze plaats op basis van autoriteit. Via planning worden doelbewust de over meerdere personen verdeelde activiteiten onderling afgestemd. Voor het verzekeren van de medewerking van bij de uitvoering van de planning betrokken partijen zal het management contracten afsluiten. Het management zal er op moeten toezien dat deze afspraken ook daadwerkelijk worden nagekomen. Aan beide alternatieven, markten en bedrijven, zijn kosten verbonden en derhalve dient er een keuze te worden gemaakt. Wanneer de kosten van produktie vermeerderd met de kosten van de produktie-coördinatie (transactiekosten) minder bedragen dan een markt-transactie voor een produkt of dienst zou kosten, zullen activiteiten en transacties binnen bedrijven worden uitgevoerd. Hiermee is meteen de 'raison d'être' van bedrijven verklaard ${ }^{22}$. Een onderneming zal dus groeien tot het moment dat de kosten van externe coördinatie van activiteiten door de markt minder bedragen dan de voordelen van interne coördinatie van deze activiteiten door het management.

De transactiekosten-benadering van Williamson is gebaseerd op Coase (1937). Deze stelde dat het management van een bedrijf continu op zoek zal zijn naar nieuwe winstkansen. Een onderneming zal dan zolang doorgroeien totdat de marginale kosten van het vinden van nieuwe winstkansen intern in de onderneming mér bedragen dan de kosten van het vinden van nieuwe winstkansen extern in de markt. In bedrijven wordt een aantal niét-markt mechanismen gebruikt zoals contracten, standaards en verslaglegging, om in het geval van informatieproblemen waardoor markten niet goed kunnen functioneren, toch tot een efficiẻnte allocatie van middelen te kunnen komen (Kaplan en Atkinson, 1989:524).

Vóór het industriële tijdperk vond de bulk van de transacties extern (op de markt) plaats en werden nog nauwelijks lange-termijn investeringen gedaan. Derhalve was er nog weinig behoefte aan interne berichtgeving en kon in alle opzichten goed worden volstaan met het externe berichtgevings-systeem (Kaplan en Atkinson, 1989:2).

Met de opkomst van investeringen in duurzame activa ontstaat tevens het probleem van de 'accruals': hierbij moest een keuze worden gemaakt met betrekking tot het al dan niet activeren van de uitgaven voor een actief. Met deze 'accruals' en het hiermee samenhan-

\footnotetext{
${ }^{22}$ Soms worden beide coordinatie-mechanismen verenigd, zoals in grote bedrijven waar interne arbeidsmarkten, interne kapitaalmarkten en interne markten voor halffabrikaten eniof diensten kunnen bestaan. Wanneer bijvoorbeeld het corporate management de investeringsvoorstellen van divisie-managers coördineert, neemt het de functie van de kapitalmarkt over.
} 
gende vraagstuk van de bepaling van het resultaat over een bepaalde periode deed accounting zijn intrede (Bell, 1986:10). Door de aanzienlijke investeringen in duurzame produktiemiddelen zijn de ondernemingen als het ware gedoemd hun produktie te continueren en in de toekomst te kijken. De belangrijkste taak van cost accounting was het bepalen van de kosten voor de verschillende tussen- en eindprodukten en het meten van de efficiency van het conversieproces ('conversion accounting').

Verdere vooruitgang in de cost accounting werd geboekt in samenhang met de 'scientific management'-beweging van Taylor. De standaardkosten- en standaardkostprijs-calculatie doen hun intrede omdat er normen beschikbaar kwamen voor bestede arbeid en verbruikte grondstoffen.

Door de investeringen in produktie-machines konden de voordelen worden genoten van produktie op grote schaal ('economies of scale'). Veel meer dan voordien werden transacties intern uitgevoerd in plaats van extern op de markt. Hiermee ontstonden grote hiërarchische organisaties, zoals in de textiel, in de staalbouw en in de spoorwegen. Bij gebrek aan een marktprijs als objectieve vertaalslag van de gevolgen van een transactie werd de cost accounting aangegrepen om een prijs te bepalen voor de 'interne output'. Voor het eerst werden nu ex-ante gegevens verzameld en verwerkt.

Standaard-tarieven, standaardkostprijzen en budgetten doen hun intrede zodat de prestaties van medewerkers kunnen worden geëvalueerd om zodoende de interne processen beter te kunnen beheersen. 'Un budget, c'est un monsieur' wordt (in dit kennelijk nog niet geëmancipeerde tijdperk) een slagzin. Tot aan het eind van de $19 \mathrm{e}$ eeuw hield accounting zich nog niet bezig met het toerekenen van constante kosten aan produkten en/of perioden. Het ging voomamelijk om de loonkosten en om de kosten van de grondstoffen. In het begin van de twintigste eeuw werd bovendien meer aandacht gevraagd voor de financial accounting omdat bedrijven meer en meer voor hun investeringen een beroep gingen doen op kapitaalmarkten. Vanaf 1900 verlangt de New York Stock Exchange dat alle genoteerde ondernemingen jaarlijks financiële overzichten publiceren. Tot 1933 was het management min of meer vrij in het bepalen van de openbaar te maken gegevens. Daarna hebben zich allerlei instituten en organisaties met de vormgeving van de publicatieregels bezig gehouden (zoals de Security Exchange Commissie -SEC- en accountantsverenigingen $)^{23}$.

Volgens Littleton is cost accounting slechts een bijprodukt van financial accounting. De opkomst van moderne ondernemingen met wijd verspreid aandelenbezit, alsmede menige crisis op aandelenbeurzen, deed de vraag naar gecontroleerde financiële verslagen aanzienlijk toenemen. Deze overzichten werden opgemaakt op basis van conservatieve

\footnotetext{
${ }^{23}$ Tegenwoordig kan het proces van 'standard selting' als een 'politiek' gebeuren worden bestempeld omdat in een democratische seluing met diverse belangen(groeperingen) rekening dient te worden gehouden (Belkaoui, 1992:10. 11).
} 
regels (onder andere historische kosten, wel 'once upon a time accounting' genoemd) waarbij objectiviteit en controleerbaarheid voorop stonden hetgeen ten koste ging van de relevantie van de gegevens. De te publiceren gegevens moesten via het boekhoudsysteem kunnen worden teruggevoerd op de oorspronkelijke transacties (de zogenaamde integratieeis). Waarden werden zo accuraat mogelijk vastgesteld per aggregaat hetgeen ten koste ging van het bepalen van de kosten per individueel produkt (Ezzamel, Hoskin en Macve, 1990:156). Het gaat in de externe berichtgeving om het bepalen van de kosten van de verkopen voor het bepalen van het verkoopresultaat ('period matching') en niet om het bepalen van de kosten per verkocht produkt voor bijvoorbeeld het stellen van prijzen ('product matching'). Hierdoor heeft het begrip 'indirecte kosten' ('overhead costs') in de externe berichtgeving een geheel andere inhoud dan in de interne berichtgeving. Als het ware veronderstelt de externe berichtgeving wat de bepaling van de omvang van het resultaat betreft een homogeen producerende onderneming, een veronderstelling die realiteit was in de periode dat de cost accounting zich ontwikkelde. Menig historisch accounting onderzoeker gaat uit van deze relatie 'cost accounting-externe berichtgeving' (Littleton, 1933).

De vraag naar gecontroleerde financiële berichten neemt ook toe wanneer managers meer en meer worden beloond op basis van de bereikte resultaten.

"...audited accounting reports had come to serve as a basis for managerial compensation by the end of the nineteenth century" (Walsch en Stewart, 1987:4).

Uiteindelijk gingen de meeste bedrijven er toe over -waarschijnlijk uit efficiency-overwegingen - slechts één systeem te gebruiken. Managers gingen de interne activiteiten op basis van dezelfde gegevens beoordelen als de gegevens die werden gebruikt voor de externe berichtgeving. Omdat in deze fase de meeste bedrijven nog slechts weinig verschillende soorten produkt voortbrachten, was dit een acceptabele procedure. Slechts in enkele landen, waar onder Duitsland, Zwitserland en Oostenrijk, volhardde men in het er op na houden van twee gescheiden systemen (misschien dat dit samenhangt met de cultuur in deze landen dat alles zo precies mogelijk - 'haargenau' - moet worden vastgesteld).

\subsection{Van cost accounting naar management accounting}

Het ontstain van de huidige management accountingpraktijk kan worden teruggevoerd tot de opkomst van de verticaal geïntegreerde en gediversificeerde ondernemingen aan het begin van de 20e eeuw (Kaplan, 1984:396). DuPont en General Motors zijn de eerste voorbeelden van deze multi-produkt producerende ondernemingen. In deze periode wordt 
door Brown het alom bekende DuPont-schema ontwikkeld waarbij een nadere specificatie wordt gegeven van het rendement op het geïvesteerde vermogen zodat beter inzicht wordt verkregen in de drijvende winstkrachten.

"... the most important and enduring management accounting innovation was the return-oninvestment (ROI) measure" (Kaplan en Atkinson, 1989:6).

De nieuwe rentabiliteitsmaatstaf maakte het mogelijk dat managers het beschikbare kapitaal konden toewijzen aan de meest winstgevende divisies.

De behoefte aan een uniforme financiële maatstaf bij managers van geïntegreerde en gediversificeerde bedrijven, deed management accounting de grenzen van cost accounting (zoals ontwikkeld in de homogeen producerende bedrijven in de negentiende eeuw), overstijgen. Wat tot dan toe niet belangrijk was, wordt de belangrijkste taak van management accounting: het bepalen van de kostprijzen voor de diverse soorten produkten en het bepalen van de relevante kosten voor bepaalde beslissingen.

Horngren drukt het onderscheid tussen cost accounting en management accounting (of managerial accounting zoals het in Noord-Amerika wordt genoemd) als volgt treffend uit:

"In an exaggerated sense, the cost accountants main mission might have been depicted as the pursuit of absolute truth, where truth was defined in terms of getting as accurate or precise costs as possible... While in management accounting the theme of 'different costs for different purposes' was stressed -a preoccupation with finding conditional truth" (Horngren, 1975:910).

De beperkingen van de 'absolute truth' benadering met betrekking tot gedragsaspecten en de volharding inzake de vraag naar zekerheid (controleerbaarheid) in de externe berichtgeving worden als hoofdredenen genoemd voor het afsplitsen van de interne berichtgeving van de externe berichtgeving (Van de Poel, 1986:23). De "conditional truth approach' zit op dezelfde lijn als wat Clark bedoelde met zijn uitspraak 'different costs for different purposes'. Het betekent dat er in management accounting studies en analyses van kosten moeten worden uitgevoerd die geen deel uitmaken van het boekhoudsysteem en niet tot de standaardprocedures behoren.

Van 1925 tot 1945 werd er relatief weinig binnen management accounting veranderd. Genoemd moeten in elk geval worden: 
1) De introductie van het denken in opportunity kosten door Coase in de jaren ' $30^{24}$.

2) Het gebruik van de interne rentevoet methode (contante waarde methode) bij het beoordelen van investeringen zoals geïntroduceerd door Dean.

3) De toepassing van de gedachte van 'overwinst' ('residual value') in het begin van de jaren '60, voor het eerst binnen General Electric Company. Hierbij wordt op de gerealiseerde winst een bedrag in mindering gebracht voor financieringskosten. Via deze 'aanpassing' van de ROI-methode voorkwam men dat managers projecten zouden afwijzen die, alhoewel ze meer rendement opleverden dan de gemiddelde totale vermogenskostenvoet, minder rendement genereerden dan het gemiddelde rendement op de reeds lopende investeringen.

Inmiddels worden de veronderstellingen van het neo-klassiek economische raamwerk waarop het accountingonderzoek in de jaren ' 50 -' 60 in hoofdzaak is gebaseerd, steeds meer bekritiseerd. De invloed van informatiekosten, de invloed van onzekerheid (ongestructureerde probleemstellingen), het principe van de begrensde rationaliteit van de beslisser en de invloed van mogelijke belangenconflicten tussen principaal en agent krijgen steeds meer aandacht.

Naast deze ontwikkelingen binnen management accounting is er ook vanaf de jaren '20 een trend waar te nemen in beheersings-systemen in het algemeen: het vak management control komt tot leven. Met name Anthony pleit voor een geïntegreerde aanpak ten aanzien van coördinatie-mechanismen en hij presenteert hiertoe een hiërarchisch kader.

Einde $60^{\prime} \mathrm{cr}$ jaren wordt de gedachte van de 'information economics' in accounting geïntroduceerd, met name door Demski en Feltham. De basisgedachte hierbij is dat er geen a priori informatiebehoefte bestaat en dat rekening moet worden gehouden met de kosten van de gegevensverwerking die noodzakelijk zijn om te voldoen aan informatiebehoeften. Ook de agency-theorie die in het begin van de jaren ' 70 tot ontwikkeling komt, kan als een belangrijke ontwikkeling in de management accounting worden gezien.

Met het verschijnen van drie belangrijke artikelen ziet Bell 1968 als een cruciaal jaar in het denken van en over accounting (Bell, 1986:18). Het eerste artikel van Feltham bevestigt de informatiecontext waarin accounting opereert. Feltham pleit met name voor het opnemen van 'anticipatory data' (Feltham, 1968:692). Het tweede artikel betreft dat van Beaver, Kennelly en Voss die nog verder gaan dan Feltham door te stellen dat accounting zich in hoofdzaak met ex ante gegevensverwerking dient bezig te houden (Beaver, Kennelly en Voss, 1968:680).

De derde in dit verband van belang zijnde publikatie is die van Ball en Brown die stellen

\footnotetext{
${ }^{24}$ Cok opportunity kosten kunnen gewoonlijk niêt aan een boekhoudsysteem worden ontleend, omdat het kosten betreft van transacties die niet zijn uitgevoerd.
} 
dat de bruikbaarheid van accountinggegevens empirisch zou kunnen worden vastgesteld door na te gaan in hoeverre kapitaalmarkten op de publikatie van deze gegevens reageren. Met genoemde publikaties wordt definitief de weg ingeslagen van de 'decision-usefullness approach' en wordt accounting als een 'informatiesysteem' gezien. Concreet betekent het een uitbreiding van het paradigma van accounting omdat thans ook gedragswetenschappelijke aspecten, informatietheorie en informatie-economie, beslissings-theorie en organisatie-theorie (zoals agency-theorie) mede onderwerp van studie zijn. Het artikel van Ball en Brown slaat tevens de weg in van het empirisch onderzoek ${ }^{25}$. Dit in tegenstelling tot het deductief-analytisch normatieve onderzoek zoals tot dan toe gebruikelijk was (zijnde een goed oud-Grieks gebruik). Mattessich stelt dat het begin van systematisch empirisch onderzoek in accounting kan worden teruggevoerd tot Argyris (1952) en met name gestimuleerd is door het werk van Cyert en March uit 1963 - 'A Behavioral Theory of the Firm' - (Mattessich, 1980:168). De accounting heeft het advies van Galilei (1564-1642), 'vader van alle moderne wetenschappen', wel erg laat opgepakt $^{26}$.

In dit verband kan de vraag worden gesteld: Wie zijn de veronderstelde gebruikers van accountinggegevens? In het gezaghebbende werk van Edwards en Bell zijn de gebruikers de managers. Edwards en Bell zien als de belangrijkste functie van financiële berichtgeving het in staat stellen van beoordelingen achteraf. In de niet minder belanghebbende werken van Sterling en Chambers worden managers eveneens als de belangrijkste gebruikers van accountinggegevens verondersteld (Fraser en Nobes, 1985:146). Sterling en Chambers evenwel zien als hoofdfunctie van management accountingsystemen het ondersteunen van beslissingen waardoor een $e x$ ante dimensie aan het systeem wordt toegevoegd.

Bromwich onderschrijft de stelling van Sterling en Chambers.

"... decision making is future-orientated whereas financial accounting is non-dynamic, backward-looking, conservative, as objective as possible and subject to statutory and other

\footnotetext{
${ }^{25}$ Empirisch onderzoek levert vaak interessante gegevens op, met name ten aanzien van de toepassing van accounting-methoden en -technieken. Zo bleek in een recent onderzoek in de Verenigde Staten dat de meeste hightech bedrijven geen enkele vorm van standaardkosten-cakulatie toepassen vanwege de korte levensduur van de produkten. Indien de verwachting is dat economische groei met name in deze sector moet worden gerealiseerd, zullen nieuwe relevante accountingmethoden en -technicken moeten worden ontwikkeld die aan deze nicuwe omstandigheden tegemoet komen. Overigens bleek ook in het bedoelde onderzoek dat regressie-analyse niet of nauwelijks werd tocgepast voor het analyseren van de variabiliteit der kosten (de bockhoudkundige indeling werd gevolgd) alsmede de sporadische toepassing van direct costing (Cornick, Cooper en Wilson, 1988:42-43). Deze laatste bevinding is in tegenspraak met Kaplans bewering dat in de Verenigde Staten kwantiatieve methoden meer en meer in de praktijk worden toegepast (Kaplan, 1981).

${ }^{26}$ Galilei hield vurige pleidooien voor het verwerven van kennis en inzichten via waameming in de praktijk (observatie).
} 
regulation. Management accounting is future-orientated, is dynamic, produces forward looking figures and is meant to be decision and control relevant, should not be too concerned with objectivity and is not generally subject to external regulation. Financial accounting is backward-looking and sacrifices decision relevance for objectivity" (Bromwich, 1988:26).

En Mednick merkt in dit verband over het FASB conceptual framework op (dit 'framework' wordt besproken in hoofdstuk 5):

"Even the FASB's conceptual framework acknowledges traditional financial statements are useful only to the extent they help discern trends and predict future" (1992:557).

De Research Board of The Institute of Chartered Accountants in England and Wales en het Research Committee of the Scottish Institute hebben in het rapport 'The future shape of financial reports' (1991) voorgesteld om aan de traditionele jaarrekening een apart overzicht toe te voegen dat betrekking heeft op de toekomst van de onderneming. In dit 'Statement of future prospects' zou een samengevatte geprojecteerde balans, resultatenbegroting en een begroot cash flow overzicht dienen te worden opgenomen. Het 'Statement of future propects' zou zich minimaal over het komende financiële jaar dienen uit te strekken en mogelijk over een nog langere periode. Misschien is triple-entry accounting wel het meest geëigende vehikel om tot implementatie van een dergelijk concept te komen.

De vraag van Merchant is in dit verband al even veelzeggend:

'Is there no other way to disclose future corporate prospects to the market? Is there a way to explain to the market that while quarterly earnings are down, this is because management has decided not to delay worthwile investments?' (1990:310).

\subsection{Samenvatting}

Zoals in dit hoofdstuk is geschetst, is de ontwikkeling van management accounting die van enkel boekhouden naar dubbel boekhouden, van dubbel boekhouden naar cost accounting en van cost accounting naar management accounting ${ }^{27}$.

Cushing schetst op schematische wijze hoe de financial accounting zich na Pacioli in de visie van Kuhn heeft ontwikkeld (Cushing, 1985:17).

${ }^{27}$ Loft onderschrijtt dit drieluik: "... management accounting evolved from the techniques of cost accounting developed in England in the late nineteenth century. Cost accounting developed because the double-cntry system of bookkeeping in factories could not provide the owners with relevant information on product costs" (Loft, 1991:19). 
1) $16 e$ eeuw. Slechts beperkte wijzigingen worden in de Italiaanse methode doorgevoerd. Door het toenemen van het aantal transacties bestond het gevaar dat het journaal en het grootboek te snel zouden vol geraken. Ook probeerde men detailgegevens in het grootboek te vermijden. In deze periode neemt dan ook het gebruik van dagboeken en subgrootboeken een vlucht. Op deze manier worden thans in het journaal en grootboek geaggregeerde gegevens verwerkt.

2) $17 e-18 e$ eeuw. Openbare periodieke financiële verslagen worden gebruikelijk, onder andere door de opkomst van de Oost-Indische Compagnie. Er ontstaat de behoefte aan controle van de overgelegde stukken en concepten als continuïteit, periodiciteit en accruals doen hun intrede. De wijze van administratie (inclusief herwaardering) van vaste activa wordt een belangrijk item. Wanneer het dubbel boekhouden ook in andere dan commerciële organisaties wordt toegepast, ontstaat de eerste kritiek. Dit geeft aanleiding tot theoretisch onderzoek.

3) $19 e$ eeuw. Diverse afschrijvingsmethoden worden ontwikkeld. Ten gevolge van de industriële revolutie wordt het produktieproces middelpunt van administratie. Vanwege de behoefte aan coördinatie-mechanismen voor deze hiërarchisch georganiseerde processen ontstaat cost accounting.

4) $20 e$ eeuw. In deze periode worden nieuwe accounting-methoden en -technieken ontwikkeld voor zaken als inflatie, leasing, pensioenen en immateriële activa.

Edwards onderscheidt in de ontwikkeling van de financial accounting een viertal fasen (Edwards, 1987:9):

1) De vóór-kapitalistische periode (4000 v. Chr. tot $1000 \mathrm{n}$. Chr.). Deze periode begint in Mesopotamië en de Griekse en Romeinse tijd maken er deel van uit. De boekhouding is voornamelijk een hoeveelheidsboekhouding (enkelvoudig boekhouden) van goederen, dieren en slaven en later geld.

2) De periode van het commerciële kapitalisme (1000-1760). In deze periode wordt het volume van de handel opgevoerd door onder andere kredietverlening en ontstaat de behoefte aan een geavanceerder boekhoudkundig systeem.

3) De periode van het industriële kapitalisme (1760-1830). In deze periode worden in met name de textiel-industrie, de staal-industrie en in de vervoerssector de eerste investeringen gedaan in duurzame kapitaalgoederen. De industrie, meer dan de landbouw, wordt 'de belangrijkste bron van welvaart.

4) De periode van het financiële kapitalisme (1830 tot heden). De investeringen in duurzame kapitaalgoederen kunnen niet meer uitsluitend via winstreservering worden gefinancierd en derhalve doen bedrijven een beroep op externe vermogenverschaffers. Hiermee wordt de kapitaalmarkt geboren. Eigendom en leiding worden gescheiden en er ontstaat een verschuiving van boekhouden naar 'financiële verslaglegging'. 
De management accounting kent zijn eigen geschiedenis. Van uit het enkel en dubbel boekhouden is rond 1800 de cost accounting ontstaan als economische implementatie van de industriële revolutie. Het bepalen van de kosten en opbrengsten per verslagperiode en als zodanig het opsplitsen van de totale kosten in 'kosten van de verkopen' (voor de resultatenrekening) en 'kosten van (onderhanden) voorraden' (voor de balans) was het centrale accountingthema. De kosten bestonden voornamelijk uit variabele kosten (grondstoffen en lonen). Ten behoeve van het steeds toenemende aantal interne transformaties dat in de fors groeiende bedrijven plaatsvindt, biedt de cost accounting uitkomst door het berekenen van een interne verrekenprijs (transferprijs) voor deze activiteiten. Aan het begin van de $20 \mathrm{e}$ eeuw wordt het activiteitenpakket van ondernemingen gediversificeerder en bovendien neemt de internationale handel toe. Het berekenen van de kosten en opbrengsten casu quo het rendement per produkt, per divisie of per afdeling, per land of per project wordt een belangrijk item in de management accounting. Aldus doen kostprijsberekeningen hun intrede. De praktijk van de management accounting floreert, met name in de VS. Na de jaren twintig gebeurt er feitelijk weinig binnen de management accounting. Wel wordt het belang van toekomstgerichte gegevens in de management accounting algemeen erkend. Hiermee splitst de management accounting zich definitief af van de financial accounting casu quo het boekhouden welke retrospectief van aard zijn, alhoewel natuurlijk het analyseren van historische data een belangrijk onderwerp in de management accounting blijft. Ten behoeve van het verwerken van onzekerheden worden in de management accounting technieken en modellen uit de statistiek (zoals regressieanalyse) en waarschijnlijkheidsleer geîntroduceerd (zoals het theorema van Bayes).

De stilstand in de ontwikkeling van management accountingsystemen die we in de jaren '20-' 80 hebben kunnen waarnemen, is deels verklaarbaar uit het overvleugeld worden door de financial accounting (Bouma, 1992:13). Door de opkomst van de grote (gereguleerde) kapitaalmarkten zagen bedrijven zich genoodzaakt steeds meer aandacht te geven aan de externe berichtgeving waarmee het interne berichtgevingssysteem naar het tweede plan verschoof.

Belangrijke ontwikkelingen in de management accounting zoals de recente studies ten aanzien van 'activity based costing' en 'strategic cost accounting' kunnen zonder meer aan het voorgaande 'logboek van management accounting' worden toegevoegd (zie voor een korte bespreking van deze nieuwe ontwikkelingen hoofdstuk 4).

Het boek van Johnson en Kaplan 'Relevance Lost' (1987) is een van de belangrijkste monografieën over de geschiedenis van accounting. De auteurs stellen met nadruk dat management accounting niet een vakgebied is dat pas na de Tweede Wereldoorlog tot ontwikkeling is gekomen. De tweede belangrijke conclusie van hun historische analyse is dat cost accounting niet is ontwikkeld om tegemoet te komen aan de normen en voorschriften inzake de financial accounting, zoals bijvoorbeeld Littleton (1933) stelt. Cost 
accounting heeft zijn eigen geschiedenis (Johnson en Kaplan, 1987:141).

Deze conclusies zijn in zoverre interessant dat ze tegenspreken wat Kaplan zèlf in eerdere publikaties heeft neergelegd.

"Management accounting is a relatively recent phenomenon, especially compared to the long historical development of financial reporting for external parties such as owners, creditors, regulators, and tax authorities. Cost accounting was the first manifestation of the current management accounting system. Cost accounting was developed to fill a need generated by the financial reporting process" (Kaplan, 1982:1). Zie ook Johnson en Kaplan, 1987:141.

Ondanks de algemene bewondering die voor het werk van Johnson en Kaplan bestaat, is er toch ook hier en daar kritiek te bespeuren omdat zij de factor 'mens' niet of nauwelijks een plaats geven in de ontwikkeling van management accounting. De omgeving van een bedrijf wordt uitgelegd als een technische context, waarin technologie en concurrentie van het grootste belang zijn.

Hopper stelt dat ontwikkelingen in de management accounting beter kunnen worden verklaard door deze te plaatsen tegen een achtergrond van ontwikkelingen van 'mens en werk' (Hopper, 1988). Hierbij gaat het zowel om het werk van de accountants zèlf als om het werk van andere mensen dat door het accountingsysteem zichtbaar wordt gemaakt. Door nieuwe arbeidsprocessen en -structuren zal het accent binnen accountingcontrol en overige controlmiddelen in de tijd fluctueren en zullen nieuwe accountingmethoden en technieken worden toegepast.

Lowry ziet als belangrijkste omissie in het werk van Johnson en Kaplan het niet onderkennen van de enorme ontwikkeling die de service-industrie (waar onder financiële instellingen) heeft doorgemaakt ten opzichte van produktie-ondememingen (1993:169179). Het betreft hier vaak kleinere ondernemingen met de volgende kenmerken: nietgestandaardiseerde output, geen routine-matige technologie, uitvoer van interactieve en samengestelde diensten, veel constante kosten en de afwezigheid van voorraden. Voor dit type ondernemingen zijn standaardkostprijscalculaties, verschillenanalyses, regressieanalyses, leercurven, optimale voorraadmodellen en lineaire programmering irrelevant en is elke toerekening van kosten per definitie arbitrair.

In hoofdstuk 4 wordt op het 'uit de pas lopen' van de management accounting nader ingegaan. 



\section{4 'State of the art' en toekomstverwachtingen management accounting}

\subsection{Inleiding}

Recente management accountingliteratuur doet vermoeden dat de thans beschikbare accounting-methoden en -technieken suboptimaal en in sommige gevallen zelfs disfunctioneel zijn.

"Yesterday's accounting undermines production" (Kaplan, 1984:95).

"Cost accounting is the number 1 enemy of productivity" (uitspraak van Goldratt aangehaald door Kaplan, 1989:419).

"Today's cost management systems are failing to provide companies with the financial information they need to manage their factories of the future succesfully" (Brimson, 1986:25).

"Corporate management accounting systems are inadequate for today's environment. In this time of rapid technological change, vigorous global and domestic competition, and enormously expanding information processing capabilities, management accounting systems are not providing useful, timely information for the process control, product costing, and performance evaluation activities of managers (Johnson en Kaplan, 1987:XI).

"Even the most casual observer of the accounting scene could not possibly be unaware of the avalanche of criticism during the past five or so years concerning the 'current state of cost/management accounting'"(Ferrara geciteerd in van der Veeken et al, 1993:171).

"Cost accounting was a powerful solution. It did change the behavior and performance of industrial companies. Industry in turn impacted the overall technology. Then technology pulled the rug out from underneath cost accounting; the assumptions on which cost accounting was based are no longer valid. The powerful solution rendered itself obsolete. Many companies are already facing the disaster resulting from following an obsolete solution" (Goldratt en Fox, 1991:34).

"The current accounting model is becoming irrelevant. Recent business failures have brought on growing criticism of the profession and repeated demands of 'Where were the auditors?'. For the longer term, we need to accelarate work on a completely new information model... 
Such a model would include not only more meaningful financial disclosure but other indicators - in fact, producers - of long-term earnings and value" (Mednick, 1992:554-557).

Johnson en Kaplan gaan zelfs zo ver in hun kritiek dat zij de bestaande accountingsystemen als een gevaar in de zin van 'counter'-produktief beschrijven.

"Today's management accounting systems provide a misleading target for managerial attentiun. Frequently, the reports decrease productivity because they require operating managers to spend time trying to understand and explain reported variances that have little to do with the ecionomic and technological reality of their operations. With an ineffective management accounting system, the best outcome occurs when managers understand the irrelevance of their system and hypass it by developing personalized information systems" (Johnson en Kaplan, 1987:22-23).

Gezien bovenstaande kritiek heeft het er alle schijn van dat management accounting op dit moment een beslissende strijd moet leveren, alhoewel sommigen dit bestrijden (zie bijvoorbeeld Porter en Akers:

"We do not believe management accounting is currently facing a cataclysm at Armageddon"; 1987:58).

Merkwaardig genoeg ontstaat de kritiek op de thans in gebruik zijnde management accountingsystemen in een tijd dat, gezien de in informatie-technologisch opzicht ongekende mogelijkheden, de kwaliteit van de financieel-economische informatievoorziening aanzienlijk zou kunnen worden verbeterd ${ }^{1}$.
"Today's designers of management accounting systems can combine such sophisticated electronic technolugy with improved software technology to devise reporting and control systems that are mort accurate, more timely, and hence, more effective than those designed by their predecessors" (I, Ihnsen en Kaplan, 1987:5).

"Is the single model for accounting records which students are taught and which accountants apply still universally appropriate? The impact of information technology on the business world suggests that the subject needs a fresh approach" (List, 1986:44).

Management accountingsystemen hebben zich in de tijd niet of onvoldoende aangepast aan veranderde strategische marktposities, nieuwe produktie-technologieën en gewijzigde

\footnotetext{
${ }^{1}$ Meestal zijn het de bestaande handmatige systemen welke zijn geautomatiseerd. Dit is feitelijk een risicomijdende en fantasieloze toepassing van informatietechnologie.
} 
organisatiestructuren, en dat terwijl de technische mogelijkheden voor bijstelling van de systemen voldoende aanwezig waren en zijn $^{2}$.

"The inadequacy of current systems arises from a lag in replacing prewar cost accounting systems, designed for financial reporting and tax purposes, with modern information and ai. counting systems" (Johnson en Kaplan, 1987:XI).

Vooropgesteld, elk accountingsysteem zal zich kenmerken door een bepaalde 'inhoudclijke resistentie voor veranderingen'. Een belangrijke taak van een dergelijk systeem is immers het meten van prestaties opdat verantwoorde oordeelsvorming daaromtrent door derden (principalen) mogelijk is. Met het oog op de functie 'verantwoording' van het accountingsysteem (zie hoofdstuk 2 ) is per definitie enige terughoudendheid ten aanzien van systeem-aanpassingen gewenst. Anders immers verliest het systeem zijn functie van 'yardstick'. Naast deze inhoudelijke vorm van resistentie bestaat er algemeen de menselijke neiging om veranderingen tegen te werken. Dit is dus niet iets waar enkel accountingpersoneel patent op heeft ${ }^{3}$. Hofstede constateert reeds in 1967 bij een praktijkonderzoek starheid/vertraging in aanpassing van het management accountingsysteem:

"...the accounting system did not coincide with the responsibility structure of the organization, mostly because the rather static reporting system had not followed recent changes in the responsibility organization" (Hofstede, 1907:32).

Over de precieze processen die zich voltrekken bij accountingsysteem-aanpassingen is nog slechts weinig bekend.

"Unfortunately, however, very little is known of the processes of accounting change. As of now we have only a limited understanding of the conditions which provide the possibility for particular conceptions of the accounting craft, the forces that put accounting into motion, the

\footnotetext{
${ }^{2}$ In dit verband is het merkwaardig te noemen wanneer een boekhouding wordt verweten gegevens op te leveren die volstrekt accuraat zijn masr niet of nauwelijks relevant. Gegevens die men niet in het systeem invoern, kan men ei immers ook niet aan ontlenen. Derhalve heeft dit niets met het vak boekhouden als zodanig te maken, maar met de betreffende administratieve organisatic. Om het verwijt aan de bockhouding kracht bij te zetten, gebruikt men wel de volgende parabel:

Een luchtballonvaarder is door de wolken zijn oriëntatie kwijt geraakt en laat daarop wat helium ontsnappen om te dalen. Nadat hij een stuk is gedaald, ziet hij iemand lopen en roept: "Meneer kunt u me zeggen waar ik ben?". De wandelaar antwoordt: "Jazeker meneer. U bevindt zich in een luchtballon en drijft in de wolken". Waarop de ballonvaarder zegt: "Uw antwoord is volstrekt accuraat meneer maar mist elke relevantie. U bent beslist hoekhouder". Waarop de wandelaar reageert: "U staat niet met beide benen op de grond meneer. Bent u sorns ondememer?". Door gebruik te maken van dergelijke 'gelikte metaforen' bespot men feitelijk zichzelf, ondat blijk wordt gegeven van slecht (accounting)management. Men verwijt de boekhouding iets waar men zelf in gebreke is gebleven dit systeem adequat te onderhouden.
}

3 "'Resistance to change' is a dominant factor in nearly all information system implementation" (Ahituv en Néumann, 1986:28). 
processes accompanying accounting elaboration and diffusion, and the varied human, organizational and social consequences that can stem from changing accounting regimes" (Hopwood, 1987:207).

Een remmende factor bij het aanpassen van het interne berichtgevingssysteem is het feit dat vrijwel alle andere bedrijfsfuncties door zo'n verandering op de een of andere wijze worden geraakt. Het accountingsysteem brengt immers de financiële kwaliteit van iedere functie in beeld en verbindt deze via de financiële noemer. Of, zoals Eiler, Goletz en Keegan dit aspect uitdrukken:

"No other system has such a pervasive effect on a company" (1982:135).

Maar ook voor accounting zal waarschijnlijk gelden wat Goldratt en Cox voor organisaties in het algemeen stellen: slechts die organisaties waarin een veranderingscultuur is gecreëerd, is het overleven gegund (Goldratt en Cox, 1986:18). Deze bewering past in de bevindingen van Markus en Pfeffer. Zij stelden in hun onderzoek vast dat de weerstand bij mensen tegen veranderingen de belangrijkste oorzaak was voor het falen van nieuwe accountingsystemen. Het probleem deed zich voor omdat te weinig aandacht was besteed aan de heersende organisatie-cultuur en de herverdeling van macht die elk nieuw systeem met zich mee brengt (Markus en Pfeffer, 1983:217).

Behalve accountingsystemen passen ook organisaties in het algemeen zich maar relatief langzaam aan veranderende omstandigheden aan. In de ecologie van organisaties is dit een van de basisgedachten (Douma en Schreuder, 1992:154). De relatieve veranderingstraagheid wordt met name gevoed door routines. Bedrijven functioneren nu eenmaal beter bij 'meer van het zelfde' (zodat het 'leereffect' zich kan doen gelden) dan bij een zich continu wijzigende uitvoering. Wanneer dan toch veranderingen moeten worden doorgevoerd, is men geneigd deze te zoeken in de buurt van de bestaande routines (men noemt dit 'local search'). De vermeende kans op succes is dan het grootst omdat men op deze manier alsnog van de opgedane ervaringen kan gebruik maken.

\subsection{Waarom falen management accountingsystemen?}

In de literatuur wordt een aantal factoren naar voren gebracht waarmee wordt getracht het waarom van het falen van de huidige management accountingsystemen aannemelijk te maken. De belangrijkste factor die wordt genoemd is wel het (te eenzijdig) gericht zijn van het accountingsysteem op de financial accounting. 
"The fundamental reason for the lost relevance of modern management accounting is the belief that businesses can both plan and control their affairs with accounting information that is compiled for financial accounting purposes" (Johnson, 1990:15).

De dominantie van financial accounting richtlijnen in management accountingsystemen komt overeen met de bevindingen van Blommaert en Van de Poel:

"All these firms used a management accounting system based on the financial accounting directives (only differences in frequency and detail had been applied)" (1987:11) ${ }^{4}$.

Het door Blommaert in 1992 uitgevoerde onderzoek waarvan de resultaten in hoofdstuk 6 zullen worden besproken, bevestigt deze bevinding.

Hartog, Molenkamp en Otten constateerden in de praktijk eveneens de exteme gerichtheid van vele gegevensverwerkende bedrijven.

"Veel gegevensverwerkende organisaties zijn bij de inrichting van de organisatie en de processen in belangrijke mate uitgegaan van aspecten van interne controle gericht op de betrouwbaarheid van de (externe) verantwoording" (1992:28).

Laatstgenoemde auteurs pleiten voor het rekening houden met meerdere (mogelijk tegenstrijdige) ontwerpvariabelen zodat er een accentverschuiving kan plaatsvinden in de functie van de bestuurlijke informatieverzorging van controle- en verantwoordingsinstrument naar besturings- en beheersings-instrument ${ }^{5}$. Ook de functiescheiding die in de traditionele administratieve organisatie centraal staat, stellen zij ter discussie omdat deze een integrale beheersvisie belemmert (1992:30-31).

Porter en Akens bestrijden de gedachte dat de praktijk van management accounting wordt overheerst door een financial accounting mentaliteit.

"Is there adequate objective evidence to support these specific charges? According to a review of the accounting literature, a survey of chief financial officers, and our own professional accounting experience, the answer is 'NO'!" (1987:58).

Ook Hopper et al (1992:310) komen tot een soortgelijke conclusie.

\footnotetext{
${ }^{4}$ Ook Kaplan merkt dit op: "Most companies want complete consistency between intemal and external accounting numbers" (1989:667).

${ }^{5}$ In hoofdstuk 5 wordt een groot aantal ontwerpvariabelen besproken alsmede de relatie die bestaat ussen deze variabelen.
} 
4 'State of the art' en toekomstverwachtingen management accounting

"..., there was no clear evidence of external reporting conventions or accounting standards being cited as adversely affecting management accounting systems".

Wat Nederland betreft kan bovendien worden gesteld dat de uitgebreide wet- en regelgeving zoals we die thans kennen, nog niet zo lang bestaat. Tot 1971 (met het in werking treden van de Wet op de jaarrekening van ondernemingen, WJO) bestond de in dit verband relevante wetgeving uit één enkel artikel in het Wetboek van Koophandel (het inmiddels vervallen artikel 42). Het werkingsgebied van deze wetgeving was bovendien beperkt tot naamloze vennootschappen. Het argument van de remmende invloed van de wettelijke regels inzake de externe berichtgeving op de ontwikkeling van management accountingsystemen kan derhalve in ons land pas vanaf de beginjaren '70 valide zijn.

Anthony neemt in bovenstaand verband het volgende standpunt in:

"...unless there is a good reason to do so, an entity will avoid the extra effort involved in maintaining a management system that is inconsistent with its financial accounting system; if management is willing to pay the extra cost of operating a management accounting system that is inconsistent with its financial accounting, this is an indication that the financial accounting standards need to be reexamined" (1983:208).

Vatter daarentegen is altijd voorstander geweest van twee gescheiden accountingsystemen zodat met name kan worden tegemoet gekomen aan de idee van 'different costs for different purposes'. Interessant was ook de gedachte van Vatter dat met een accountingsysteem niet enkel vragen moeten kunnen worden beantwoord, maar dat dit systeem ook vragen bij het management moet oproepen. Deze functie van 'eye-opener' van management accounting wordt door Simon 'attention directing' genoemd (zie ook Blommaert, Blommaert, Hayes, 1991:5).

Ook Clark pleitte expliciet voor het bestaan van twee gescheiden accountingsystemen.

"Undoubtedly, the ultimate solution lies in the development of systems of cost analysis which shall be seperated from the formal books of account, though based on the same data" (Clark in Kaplan, 1984:396).

Mogelijke verklaringen voor het op grote lijnen gelijk houden van het management accountingsysteem met het financial accountingsysteem, kunnen zijn gelegen in de volgende factoren: 
1) In grotere ondernemingen is het topmanagement door aandeelhouders benoemd. Periodiek brengt dit management aan de aandeelhouders verslag uit over de met het beschikbaar gestelde vermogen bereikte resultaten. Dit verslag dient volgens wettelijke voorschriften te zijn ingericht.

$\mathrm{Nu}$ is bekend dat managers hun submanagers het liefste beoordelen op een wijze zoals ze zelf ook worden beoordeeld. Hopwood (1975:46) noemt dit het 'contagion effect'. Wanneer het topmanagement wordt beoordeeld op cijfers ontleend aan een wettelijk kader, kan dit ertoe leiden dat het topmanagement ook het functioneren van submanagers aldus wenst te beoordelen. Dit betekent dat het externe wettelijke kader ook intern gaat gelden voor de informatievoorziening.

2) Een accountingsysteem is een informatiesysteem en het beoogt als zodanig onzekerheid te reduceren (het systeem beoogt een positief gewaardeerde revisie van waarschijnlijkheden voor de gebruiker mogelijk te maken). Wanneer er twee afzonderlijke accountingsystemen op na worden gehouden, schept dit wellicht meer onzekerheden dan met deze systemen kunnen worden weggenomen.

3) Grootte en aard van de organisatie. Bij minder complexe of sterk gedecentraliseerde organisaties heeft het (lokale) management minder behoefte aan een afzonderlijk (formeel) informatiesysteem omdat het persoonlijk zorg draagt voor de benodigde gegevens, onder andere door op gezette tijden lijfelijk bij de produktie aanwezig te zijn en dan waar nodig direct in te grijpen ('management by walking around'). Het informatiesysteem is in deze gevallen goeddeels informeel.

4) Het economisch aspect (kosten versus opbrengsten).

5) Het geheimhoudings-aspect. Concurrentie- of kapitaalmarktgevoelige gegevens kunnen moeilijk geheim worden gehouden wanneer deze zich in een geformaliseerd systeem bevinden.

Naast de beperkende invloed van de wettelijke regulering inzake de externe verslaglegging bestaat er voor wat betreft de management accounting het probleem dat de informatiebehoeften van de gebruikers, met name die van het management, moeilijk exact te definiëren zijn en bovendien per groep van gebruikers bijzonder divers zijn. Managers zijn vaak onvoldoende in staat ondubbelzinnig aan te geven hoe zij bij beslissingen te werk gaan. Derhalve kan de management accountant ook maar in beperkte mate de uitvoer vaststellen welke moet worden verstrekt ter ondersteuning van de besluitvorming. Oonincx wees reeds eerder op dit probleem (1982:23) hetwelk onlangs nog door Oppelland werd bevestigd (1990:5). Inmiddels poogt men niet langer te verzanden in het topdown achterhalen van informatiebehoeften van managers (de EDP-aanpak) of in het beschrijven van de beslissingsprocessen in effectiviteitsrelaties (de MIS-aanpak). In plaats daarvan probeert men met behulp van de informatiesystemen het management te helpen en te ondersteunen in probleemsituaties om zodoende de effectiviteit van beslissingen te 
verbeteren. Dergelijke systemen worden decision supportsystemen (DSS) genoemd (Bosman en Sol, 1984:141).

De accountingwetenschap wordt eveneens een dubieuze rol toebedacht bij de huidige crisis van de management accounting. Volgens Johnson en Kaplan is het accountingonderzoek van na de Tweede Wereldoorlog gedomineerd door het neo-klassieke model dat ook algemeen economen in hun analyses toepasten. De van dit paradigma af te leiden beslissingsmodellen zijn zo sterk gesimplificeerd (onder andere ten aanzien van aspecten van menselijk gedrag en de samenstelling van de produktie) dat zij voor de complexe accountingpraktijk niet of nauwelijks relevant zijn (Johnson en Kaplan, 1987:145).

Dat in de jaren ' 60 en ' 70 de produktie geen onderdeel uitmaakte van de centrale ondernemingsstrategie maar wel bijvoorbeeld overnames, fusies en financiering (Lee, 1987:35), kan eveneens van invloed zijn geweest op de beperkte vernieuwing van management accountingsystemen in deze periode. Het management was voornamelijk extern georiënteerd, dit in tegenstelling tot bijvoorbeeld de Japanners die in deze periode zeer innovatieve produktiemethoden introduceerden waarvan zij tot op de dag van vandaag de vruchten kunnen oogsten.

Bromwich en Bhimani vatten de belangrijkste problemen van de huidige management accounting als volgt samen:

"1. The alleged subservience of management accounting to external financial accounting requirements.

2. The lack of strategic considerations in management accounting and project appraisal.

3. The reliance of management accounting on redundant assumptions concerning manufacturing processes.

4. The maintenance of traditional assumptions in performance evaluation and the continued short-term orientation of this process" (1989:5).

Van der Veeken, Corbey en Wouters tenslotte wijzen op een vicieuze cirkel waarin de management accounting zich thans mogelijk bevindt. Naarmate de toeleveranciers van basisgegevens niet echt overtuigd zijn van de relevantie van de bestaande management accountinginformatie, zullen zij het met de aanlevering van de gegevens niet zo nauw nemen (1993:173).

Samenvattend worden de volgende factoren voor het falen van management accountingsystemen naar voren gebracht: 
1) Het te eenzijdig zijn gericht op de externe verslaglegging.

2) De onnauwkeurige en/of onvolledige formulering door het management van zijn informatiebehoeften.

3) De sterk analytische benadering van de accountingwetenschap, zonder voldoende oog te hebben voor menselijke gedragseffecten en de complexiteit van de werkelijke produktieprocessen.

4) De externe gerichtheid van het hogere management in de jaren '60-' 70 . Hierdoor werd minder aandacht besteed aan de interne organisatie van de produktie alsmede - en dientengevolge - aan de ontwikkeling van interne informatiesystemen.

\subsection{Behavioral accounting}

Anderen zien als het grootste tekort van de huidige praktijk van de management accounting het onvoldoende rekening houden met de gedragswetenschappelijke effecten ervan (Weezenberg, 1989). In deze visie is het 'menselijke gezicht' van management accounting te weinig ontwikkeld en wordt het vak te sterk bedreven als een geheel van rationalisatiemethoden en procedurele technieken, als antwoorden op zoek naar problemen. Accounting daarentegen is een gedragsmatig proces. Het gaat over mensen, zowel als producenten en als consumenten van informatie. Van de door de management accountant verstrekte gegevens en daarop gebaseerde adviezen wordt verwacht dat deze het toekomstige gedrag en attitudes van mensen zullen beïnvloeden.

Birnberg en Nath gaven al veel eerder het belang aan van de sociale context waarin accounting zich voltrekt:

"The management information system of any firm is not solely a technical communication system, one designed only to permit data to flow from one point in the system (i.e., the firm) to another. Rather it is intended that the data selected and transmitted both serve as inputs to managers' en workers' decision processes and effect their behavior". En even verder: "... accountants must undertake behavioral research" (1967:468).

Mullins drukt zich in soortgelijke bewoordingen uit.

"...if the accountant's contribution to management and to improving organisational effectiveness is to be maximised then he needs an understanding of the factors which effect the behaviour of people within the work environment and at least a working knowlegde of psychological and sociological theory and its relationship to business practice" (1981:36).

Fox en Goldratt zijn heel expliciet in de relatie accounting/gedrag: 
"Tell me how you measure me and I'll tell you how I'll behave" (1989:18).

Het gedrag dat wordt beloond is derhalve het gedrag dat van medewerkers moet worden verwacht.

Merchant komt tot eenzelfde conclusie. Indien mensen de druk van financieel-economische prestatienormen (te) sterk voelen, bestaat de neiging:

1) gegevens te manipuleren (bijvoorbeeld door toepassing van 'income smoothing'); en

2) zich in hoofdzaak op de korte-termijn te richten waarbij bijvoorbeeld op (noodzakelijke) research wordt gekort (Merchant, 1990:311).

Ook Boons ziet in het implementeren van gedragswetenschappelijke aspecten een bijdrage tot een oplossing van de malaise waarin management accounting verkeert.

"Het vinden van nieuwe technieken en instrumenten zou tenminste langs twee wegen moeten geschieden. Enerzijds de ontwikkeling of toepassing van kwantitatieve technieken gericht op meting en voorspelling van 'zachtere' waarden, anderzijds in de sfeer van de gedragswetenschappelijke benadering" (1990:9).

Lee laat geen misverstand bestaan over het belang van gedragsaspecten bij accounting:

"... accounting is as much a behavioral process as it is a technical one. If accounting ignores human behavior, it becomes no more than a meaningless and costly burden to business" (1972:223).

Als van groot belang voor accounting ziet Lee de volgende psychologische items: perceptie, motivatie en attitudes (1972:226). De accounting-methoden en -technieken waarvan wordt gebruik gemaakt kunnen de perceptie, motivatie en attitudes van het personeel en overige bij de onderneming betrokkenen direct beïnvloeden. Accountants en managers die de invloed van gedrag op accounting en van accounting op gedrag onvoldoende onderkennen schaden, aldus Lee, de toekomstige ontwikkeling van het vakgebied (Lee, 1972:233). Sociologische perspectieven op accounting betreffen met name de wijze waarop een accountingsysteem de sociale structuur in een organisatie construeert, onderhoudt en wijzigt ('structuration theory'), de wijze waarop accounting de belangen van met name 'het kapitaal' behartigt en een analyse van accounting en machtsverhoudingen casu quo het beheersen van conflicten tussen groepen van mensen. In al deze benaderingen is accounting veel meer dan uitsluitend een techniek. 
In het kader van met name de budgettering is inmiddels veel onderzoek gedaan op de gedragseffecten hiervan. Bijvoorbeeld de invloed van participatie, de mate van beheersbaarheid van de gebudgetteerde grootheid en de hoogte van het ingestelde budget op de effectiviteit van het budgetsysteem is door diverse onderzoekers geanalyseerd (zie met name Hofstede ${ }^{6}, 1967 ;$ Merchant, 1986; Merchant, 1989).

Agency-theorie is een goed voorbeeld van gedragswetenschappelijk onderzoek omdat de management accounting hierbij uit zijn technische context wordt gehaald en wordt geplaatst tegen de achtergrond van het (politieke) organisatieraamwerk waarin deze dient te functioneren. De analytische agency theorie zoals geformuleerd door Jensen en Meckling ontwikkelt zich wat dit betreft steeds meer in de richting van spel-theoretische formuleringen en interpretaties?

\subsection{Enkele nieuwe ontwikkelingen in de management accounting}

Als reactie op de ter discussie staande actuele staat van dienst van management accountingsystemen kunnen met name belangrijke ontwikkelingen worden genoemd als strategic management accounting en activity based costing.

"Our book responds to these harsh criticisms of the current cost accounting systems by providing a new framework, strategic cost analysis, which adapts the traditional body of knowledge called cost analysis to the rapidly developing body of knowledge on strategy formulation and implementation" (Shank en Govindarajan, 1989:X).

\footnotetext{
${ }^{6}$ In het onderzoek van Hofstede bleek dat op langere termijn 'participatie' veel minder effect had op de effectiviteit van het budgetsysteem dan was aangenomen. De mate wasin het management een sfeer wist te crelren van sporticve uitdaging en derhalve in de prestatie-gerichtheid een spel-element introduceerde, bleek een veel hoger verklarend vermogen te hebben. Hofstede noernde de titel van zijn dissertatie dan ook niet 'Participation in Budget Control' maar 'The Game of Budget Control'. Overigens werd Hofstede in zijn onderzoek ook de rituele, functie die accounting kan vervullen, gewaar. Met name manifesteerde zich dit in de weerstand van medewerkers toen hij bepaalde lokale accountingroutines welke met een minuscule precisie werden uitgevoerd, ter discussie stelde (1985:4-5).

${ }^{7}$ De speltheorie is een wiskundige discipline welke zich bezighoudt met het opstellen en analyseren van wiskundige modellen voor situaties waarin conflicten bestaan (Peters, 1986). 'Spelgedrag' is in dit verband gedrag dat uitsluitend gericht is op het verbeteren van de eigen prestatie, afgemeten aan de produktiecijfers zoals die in het accountingsysteem worden ingevoerd. Het 'maximin criterium' en 'minimax regret criterium' zijn voorbeelden van oplossingsstrategieèn die de speltheoric biedt om in dergelijke situaties een uitweg te vinden (Weber, 1982:675).

${ }^{8}$ Het 'Système croise' van Jean-Pierre Lagrange en Michele Saint-Ferdinand zoals men in Frankrijk propageert en waarbij men probeert te komen tot een analytische resultatenrekening, kan evenzeer worden beschouwd als cen belangrijke ontwikkeling. "..le Systeme croisé propose une nouvelle conception systémique de P'information. comptable. Selon cette conception, les informations de l'entreprise à partir d'un système comptable unique cohérent. L'opposition apparente entre comptabilité générale et comptabilité analytique disparaît et les informations habituellement obtenues par des traitements ou retraitements extra-comptables sont désormais fournies par la comptabilite". (Normalisation Comptable et Gestion de L'Entreprise, 1990).
} 
In de 'strategic management accounting' wordt geanalyseerd hoe de management accounting een bijdrage kan leveren aan de selectie en implementatie van de optimale concurrentiestrategie. Derhalve worden in dit kader de gevolgen bestudeerd van de strategie voor de totale financiële beheersing en speelt derhalve ook het afstemmen van het management accountingsysteem op de fase van ontwikkeling van het bedrijf een belangrijke rol. In de strategic management accounting (of 'strategic cost analysis') worden met name die gegevens verzameld zodat de eigen cijfers over kosten en bijvoorbeeld marktaandelen kunnen worden gerelateerd aan die van de concurrenten. Bij de beschikbaarheid van relatieve gegevens kan een aantal tekortkomingen van de traditionele berichtgeving worden ondervangen. Wanneer bijvoorbeeld de huidige winst is afgenomen uit hoofde van kosten ten behoeve van een verbeterde concurrentiepositie, kan dit positief worden uitgelegd. In 'strategic management accounting' staat de gedachte centraal dat winst geen uitvloeisel is van investeringen sec maar van een gunstige positie in een concurrerende markt. Het winstcijfer dient dan ook tegen die achtergrond te worden geprojecteerd (Simmonds, 1981:7).

Strategic management accounting rust met name op onderzoeks-bevindingen in het vakgebied 'industriële organisatieleconomie'. In dit onderzoek wordt een relatie gelegd tussen bedrijfsomgeving ('structure'), strategie ('conduct') en bedrijfsresultaten ('performance'). Langs deze weg probeert men verklaringen te geven voor bijvoorbeeld verschillen in rendement per bedrijfstak. Dit vindt plaats door variabelen uit de bedrijfsomgeving (zoals aantal concurrenten en consumenten, prijs-elasticiteit en instapdrempels) als verklarende variabelen te gebruiken.

Zoals opgemerkt wordt ook activity based costing (ABC) voorgedragen als een nieuwe ontwikkeling die moet worden aangegrepen om management accounting uit het slop te halen.

"Will $A B C$ be the system to fill the vacuum caused by the growing irrelevance of conventional management accounting techniques?" (Bailey, 1991:30).

Over het belang van $\mathrm{ABC}$ merkt Johnson het volgende op:

"Robin Cooper's two-stage product costing concept is a powerful idea. It certainly ranks as one of the two or three most important management accounting innovations of the twentieth century" (1990:15).

Maar tegelijkertijd wijst Johnson ook op de gevaren die kunnen bestaan bij het hanteren 


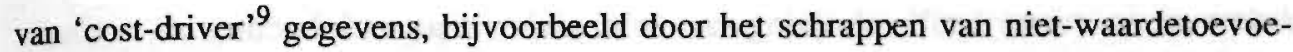
gende activiteiten. Dit zou er volgens Johnson toe kunnen leiden dat bedrijven activiteiten efficiënt gaan uitvoeren welke zij evenwel niet in de eerste plaats ter hand zouden moeten nemen. Centraal staat aldus Johnson het creëren van concurrerend vermogen, dit is het op winstgevende wijze en continu kunnen voldoen aan de wensen van afnemers (Johnson, 1990:18).

Overigens wijst Kaplan er op dat ABC lang niet zo'n nieuwe methode is als men soms wil doen geloven. Ervaren bedrijfsadviseurs passen vergelijkbare analysemethoden al ruim 20 jaar toe bij hun strategische bedrijfsonderzoeken (Kaplan, 1990:10). Blommaert, Eimers en Groot bevestigen deze stelling door middel van een conceptuele analyse van $\mathrm{ABC}$ ten opzichte van de alom bekende, maar in de huidige praktijk slechts sporadisch of in een van het basismodel afwijkende vorm, toegepaste produktiecentra-methode, ook genoemd kostenplaatsenmethode (1992:115). Ook Ijiri wijst in 1966 al op een vorm van activity accounting die mogelijk nieuwe informatiebehoeften kan bevredigen: physical accounting. Hierbij worden twee typen grootboekrekeningen gebruikt: voor activa enerzijds en voor activiteiten anderzijds. De grootboekrekeningen voor de activa worden geadministreerd in fysieke eenheden (er vindt dus geen omrekening in geldeenheden plaats). De grootboekrekeningen voor de activiteiten bestaan uit winst- en verliesrekeningen maar ook uit rekeningen voor bijvoorbeeld het aflossen van leningen, het innen van vorderingen, verkopen, grondstofaankopen, en dergelijke. Om tot aggregatie te kunnen komen, dient voor een bepaalde waarderingsmethode te worden gekozen (zoals historische kosten of actuele kosten; Ijiri, 1966:155).

Ook inmiddels ver uitgewerkte en veelvuldig toegepaste accountingmethodieken, zoals inflation accounting (current cost accounting) en de verwerking van pensioenen en leasecontracten in de jaarrekening, kunnen worden gerekend tot ontwikkelingen, geboren uit onvrede met bestaande accounting conventies (met name de eenzijdige juridische grondslag) en daarop gebaseerde systemen.

Bij overwegingen van herontwerp van management accountingsystemen dient ook tripleentry en momentum accounting zoals voorgesteld door Ijiri $(1982,1986,1989)$ te worden beoordeeld. Deze 'beoordeling' komt uitgebreid in hoofdstuk 7 aan de orde. Wat ontbreekt aan het indrukwekkende werk van Ijiri is een comptabel model waarin de derde dimensie, oorzakelijke winstmutatie, kan worden geregistreerd. Resultaat van het onderha-

\footnotetext{
${ }^{9}$ In ABC wordt er van uitgegaan dat de kosten niet uitsluitend worden bepaald door de omvang van het produktievolume maar tevens door de produktiesamenstelling ('scale' én 'scope'). Voor elk produkt of dienst is cen aantal produkticactiviteiten noodzakelijk en de omvang en aard van deze activiteiten bepalen dan ook hoeveel kosten elk produkt krijgt toegerekend. In deze zin zijn de produkticactiviteiten de 'cost drivers'. In principe worden bij ABC alle kosten als variabele kosten beschouwd. Deze 'variabiliteit' slaat dan niet enkel op de produktie-omvang maar ook op de aard van de produktieactiviteiten, zoals bestellingen, reparaties, omstellingen en te lossen vrachtwagens.
} 
vige onderzoek is tevens een beschrijving van zo'n model waarin triple-entry en momentum accounting kunnen worden uitgevoerd (zie hiervoor hoofdstuk 8). In tegenstelling tot bijvoorbeeld strategic management accounting en activity based costing zoeken tripleentry en momentum accounting een oplossing aan de basis van accountingsystemen omdat hierbij het alom gebruikte 'accounting measurement'-model ter discussie wordt gesteld. Omdat dit een wijziging betekent in het accountingdenken van ongeveer 500 jaar oud (na Pacioli), zal veel 'resistance for change' zijn te overwinnen. Maar ook de stoommachine moest na zijn ontdekking door de Griek Hero in de derde eeuw voor Chr. ruim 2000 jaar wachten op zijn brede toepassing...

Behalve nieuwe ontwikkelingen is ook te verwachten dat managers het accountingsysteem verdergaand zullen negeren omdat dit steeds meer irrelevant wordt. $\mathrm{Zij}$ zullen er wellicht een eigen (informeel) systeem op nahouden (Johnson en Kaplan, 1987:5) of zij kennen bijvoorbeeld extra speling ('slack') aan hun agenten toe waardoor de behoefte aan informatie in algemene zin afneemt (Galbraith, 1973). Ten aanzien van de eerste (nood)oplossing merkt Drenth terecht op:

"Het gevaar van het structureel en onbeheerst laten bestaan en uitbouwen van dit soort extracomptabele subsystemen is in een onderneming, bezien van uit de bestuurlijke informatieverzorging, niet gewenst. De continuïteit en de kwaliteit van de gegevensverwerking zijn zo niet gewaarborgd. Daarenboven werkt dit inconsistentie van gegevens binnen de onderneming in de hand" (1992:8).

\subsection{Enkele toekomstverwachtingen met betrekking tot de management accounting}

Door de intensivering van de wereldhandel, nieuwe managementfilosofieën (stijlen van management) en daarmee samenhangende organisatiestructuren, nieuwe produktiemethoden en -technologieën (met name in Japan), nieuwe informatie-technologieën en door een veranderde visie op de factor 'mens' in de organisatie ${ }^{10}$, is de omgeving waarin de management accounting dient te opereren aanzienlijk gewijzigd (zie onder andere Lee, 1987:IV). Een aantal van de gesignaleerde ontwikkelingen is nog niet geheel uitgekristalliseerd. Vandaar dat hiema soms een 'open-end'-standpunt zal worden ingenomen.

Steeds meer zullen bedrijven in de toekomst klantgericht moeten opereren. De produktie van verkoopbare produkten vervangt de verkoop van geproduceerde produkten (van technologisch- naar marktgestuurd management). Derhalve zal veel meer op bestelling

\footnotetext{
${ }^{10}$ Onder meer tot uitdrukking komend in de human resource accounting, maar ook bijvoorbeeld in onderzoeken waarbij het anticiperende gedrag van managers op bepaalde belonings-structuren wordt geanalyseerd.
} 
dan op voorraad worden geproduceerd en verdwijnt in veel bedrijven de massaproduktie. Hiervoor in de plaats komt uit de verkoopmarkt gestuurde batchproduktie. Derhalve is er een ontwikkeling van 'downscaling': produktie op grote schaal wordt in veel bedrijven vervangen door produktie in kleinere hoeveelheden. Zoals in de Japanse bedrijven gebeurt, zal in vele gevallen een van de markt afgeleide toegestane kostprijs ('target costing') uitgangspunt zijn voor de beoordeling van produktieprocessen ${ }^{11}$.

Levertijden zullen kort moeten zijn. Dit betekent dat de totale produktieketen (mens en machines) een grote flexibiliteit aan de dag moet kunnen leggen, bijvoorbeeld tot uitdrukking komend in lage omsteltijden voor produktie-lijnen. Hierbij zal zowel een daling van de voorraadkosten (onder andere realiseerbaar via een Just-in-Time beleid (JIT) als een daling van de personeelskosten worden nagestreefd. De gevolgen voor de accountingsystemen zijn evident: Het verschil tussen 'kosten van de verkopen' en 'kosten van de voorraden' is in veel gevallen niét meer significant. In veel gevallen zullen alle periodekosten als kosten van de verkopen kunnen worden aangemerkt.

De directe loonkosten zullen procentueel sterk afnemen en vormen geen goede basis meer voor het toerekenen van overheadkosten. Door de flexibiliteit die van de produktieketen wordt verlangd, worden de loonkosten van het produktiepersoneel zélf overhead. Met de vereiste flexibiliteit komt ook de praktijk van de 'kostenplaatsenmethode' (produktiecentramethode) in het gedrang omdat de homogeniteit in de produktie-activiteiten per afdeling verdwijnt ${ }^{12}$. In plaats hiervan zal de nadruk komen te liggen op een activitcitgeoriënteerde kostentoerekening $(\mathrm{ABC})$ casu quo wordt de doorlooptijd ('cycle time' of 'throughput time') een belangrijke verdeelsleutel bij het toerekenen van de overheadkosten naar de diverse kostendragers.

De formule van Harris c.q Camp voor het bepalen van de optimale bestelgrootte zal in het ongerede raken omdat hierin de kosten van neenverkopen schromelijk worden onderschat (meestal worden deze kosten nihil verondersteld).

Bedrijven die inspelen op JIT zullen vaker kleinere hoeveelheden bestellen (dit is ook een gevolg van het 'downscaling'-effect). De leverancier zal hierop moeten inspelen door zich in de nabijheid van zijn afnemers te vestigen en door aangepaste vervoermiddelen te gaan gebruiken (vrachtwagenvervoer ten koste van bijvoorbeeld vervoer per schip of per trein).

\footnotetext{
${ }^{11}$ Bij target costing worden behalve een hoogwaardige kwaliteit met name ook drastische kostenbesparingen nagestreefd door bij het produktontwerp en bij de produkt-ontwikkeling 'value engineering' toe tc passen. Dit is cen vorm van 'activity based management' waarbij wordt getracht niet-waardetocvoegende activiteiten ti elimineren. Wat waarde is, wordt bepaald vanuit het gezichtspunt van de consument (/wabuchi et al, 1994:1-10).

${ }^{12}$ Het concept van de kostenplaatsenmethode blijft evenwel overeind. Een kostenplaats is in deze zin de verzameling van kosten van een homogene produkticactiviteit. Echter, in de praktijk heeft men kostenplaatsen vaak als de in de organisatie gecreserde afdelingen uitgelegd, terwijl die afdelingen heterogene activiteiten uitvoeren.
} 
De flexibiliteit die ook van werknemers zal worden verlangd betekent dat bezettingsgraden van machines minder relevant zijn omdat het personeel ook aan andere machines kan werken. Van het personeel zal voortdurende aandacht worden gevraagd voor kwaliteitsbewaking. Werknemers zullen hun eigen geproduceerde onderdelen in een latere fase van het produktieproces nog eens terugkrijgen voor verdere afhandeling. Dit verhoogt hun betrokkenheid bij de kwaliteitsbewaking en voorkomt onnodige voorraadvorming. Werknemers zullen steeds meer worden gestimuleerd mee te denken in een proces van voortdurende innovatie ${ }^{13}$. Dit betekent dat hen bepaalde experimentele (budget)ruimte moet worden gelaten. In de traditionele verschillenanalyse betekent dit dat de druk op efficiency niet ten koste mag gaan van innovatie. Trade-offs tussen prijs-, efficiency- en kwaliteitsverschillen zijn van groot belang. Beter is te streven naar een globale totale optimalisatie (zoals binnen JIT) in plaats van naar partiële efficiency. Ackoff drukt zich in dit verband als volgt uit:

"If each part of a system, considered seperately, is made to operate as efficiently as possible, the system as a whole will not operate as effectively as possible" (1981:18).

Lange-termijn beoordelingen zijn gewenst zodat kostenreducties niet worden doorgevoerd op rekening van lange-termijn kosten zoals minder kwaliteit en verlengde levertijden.

Bolwijn heeft op treffende wijze de ontwikkelingen in de periode '60-'90 ten aanzien van markteisen, beoordelingscriteria en bedrijfsvorm in een schema weergegeven.

Tabel 4.1 Markteisen, performance criteria en ideaaltypische ondernemingen in de periode 1960 tot 2000 .

\begin{tabular}{|l|l|l|l|}
\hline & Markteisen & $\begin{array}{l}\text { Performance } \\
\text { criteria }\end{array}$ & $\begin{array}{l}\text { Bedrijf } \\
\text { (ideaaltype) }\end{array}$ \\
\hline '60 & prijs & efficiency & de efficiënte firma \\
\hline '70 & $\begin{array}{l}\text { prijs, } \\
\text { kwaliteit }\end{array}$ & $\begin{array}{l}\text { efficiency } \\
+ \text { kwaliteit }\end{array}$ & de kwaliteits firma \\
\hline '80 & $\begin{array}{l}\text { prijs, } \\
\text { kwaliteit, } \\
\text { keuze/levertijd }\end{array}$ & $\begin{array}{l}\text { efficiency } \\
+ \text { kwaliteit } \\
+ \text { flexibiliteit }\end{array}$ & de flexibele firma \\
\hline '90 & $\begin{array}{l}\text { prijs, } \\
\text { kwaliteit, } \\
\text { keuze/levertijd, } \\
\text { uniekheid }\end{array}$ & $\begin{array}{l}\text { efficiency } \\
+ \text { kwaliteit } \\
+ \text { flexibiliteit } \\
+ \text { innovativiteit }\end{array}$ & de innovatieve firma \\
\hline
\end{tabular}

${ }^{13}$ In Japan wordt dit 'kaizen' genoemd. 
Economisch gezien schetst Bolwijn een ontwikkeling van produktieomvang naar produktiekwaliteit, naar produktiediversiteit en -snelheid naar produktiedifferentiatie. Een bedrijf dat succesvol wil opereren zal in elke fase gelijktijdig aan de genoemde prestatie-criteria moeten kunnen voldoen. Deze criteria kunnen derhalve als kritieke succesfactoren worden beschouwd en het is van belang dat het management accountingsysteem gegevens over deze factoren verzamelt en aan het management presenteert.

De factor arbeid/mens zal waarschijnlijk in toenemende mate als het belangrijkste actief van bedrijven worden beschouwd (een ontwikkeling van hardware naar software naar 'brainware'). Periodieke beoordeling is gewenst en team-produktie zal waarschijnlijk toenemen (als vervanging van de traditionele 'estafette-benadering'). Dit alles heeft zijn gevolgen voor de inhoud en frequentie van de financieel-economische rapportage. De besluitvorming zal nog meer 'bottom-up' plaatsvinden (onder andere van belang voor de budgettering). Analoog aan de ideeën van Ouchi en zijn naar hem genoemde 'theorie Z' zal de administratieve organisatie meer op vertrouwen dan op wantrouwen moeten worden gestoeld. De hiermee gepaard gaande toenamen van personeelsmotivatie en produktiviteit dienen te worden afgewogen tegen de eventuele kosten van een minder waterdichte controle. Van medewerkers wordt verwacht dat ze denken terwijl ze werken, zodat continu innovatieve impulsen het management kunnen bereiken.

Door de automatisering zal ook het verloop van het leereffect (de leercurve) worden beïnvloed (Hirsch, 1988:175). In de aanvangsfase zal de aanpassing op nieuwe technologie moeilijker kunnen verlopen. Maar vervolgens kan, wanneer eenmaal het computergeintegreerde produktiesysteem draait, het proces bij voortduring op identieke wijze worden herhaald.

In een flexibele produktie-omgeving nemen de gebruiksmogelijkheden van machines toe. Dit betekent een toename van de economische gebruiksduur van de produktiemiddelen. Door evenwel de extra kasstromen die hier een gevolg van zijn te disconteren, wordt aan dit aspect (te) weinig aandacht gegeven. Immers, kasstromen die verder weg in de toekomst liggen worden lager gewaardeerd. De hoge initiële kosten die vaak met investeringen in nieuwe technologie gaan gepaard, versterken dit effect. Gevolg is dat dergelijke investeringen bij beoordeling volgens de klassieke benadering, economisch onverantwoord lijken, terwijl feitelijk de onderneming vaak geen keuze heeft in het al dan niet investeren in modeme technologie (Kaplan en Atkinson, 1989:480). De wijze van investeringsbeoordeling dient derhalve te worden aangepast, met name door rekening te houden met voordelen uit hoofde van afname van de voorraden, verbeterde kwaliteit en service en verminderde behoefte aan fabrieksoppervlakte. De financiële impact van dergelijke factoren wordt in traditionele accountingsystemen vrijwel nimmer expliciet gemeten en/of geregistreerd. 
Hiërarchie als coördinatiemiddel zal binnen organisaties in de toekomst aan belangrijkheid inboeten. Uit anarchie worden de beste ideeën geboren (Peters, 1992:43). Matrixorganisaties zullen steeds minder voorkomen omdat zij te star zijn om op de zo snel bewegende markten in te springen. Het management accountingsysteem zal zich dientengevolge meer in informele zin ontwikkelen.

Het aandeel van de constante kosten in de totale kosten zal vermoedelijk verder toenemen. Dit betekent dat het gebruik van de variabele kostencalculatiemethode ('direct costing') zal kunnen afnemen.

"Absorption costing becomes the only meaningful costing method" (Lee, 1987:144).

Enerzijds zullen de overheadkosten door de veranderde produktie-omstandigheden verder toenemen. Anderzijds wordt het steeds goedkoper om bepaalde kosten direct te registreren, bijvoorbeeld door bij de ontwikkeling van een produktierobot te voorzien in een sensor ten behoeve van bepaalde gegevensregistraties. Ook de bar-codering en de laserscanning in het algemeen dragen hiertoe bij.

Wellicht is een aanpassing van het waardeconcept aan de orde. Management accounting dient toekomstgericht te zijn. Dan is een object niet zozeer waard wat er voor is betaald (historische kostprijs) of wat er nu bij vervanging voor zou moeten worden betaald (actuele waarde/vervangingswaarde), maar veeleer datgene wat er in de toekomst mee kan worden verdiend (Izeboud, 1992:37).

In hoofdstuk 7 wordt aannemelijk gemaakt dat een deel van de ontwikkelingen in de natuurkunde model heeft gestaan voor ontwikkelingen in de accounting en voor ontwikkelingen in de economische wetenschap in het algemeen (zie ook Klant, 1987:33). Ook Pacioli was in eerste instantie een wis- en natuurkundige. Maar de aard van de accountingwetenschap is feitelijk een geheel andere dan die van de natuurkunde. Een natuurwetenschap, zoals de natuurkunde en de biologie, is een empirische wetenschap waarin onderzoek wordt verricht naar de werking van natuurverschijnselen. Daarentegen is de accounting, zoals ook de psychologie, de sociologie en de geneeskunde, een menswetenschap (of geesteswetenschap). Een menswetenschap is even-eens een empirische wetenschap, maar hierin staat de bestudering van het menselijk gedrag (in al zijn facetten) centraal.

Empirische wetenschappen staan tegenover formele wetenschappen zoals de wiskunde. In een formele of fundamentele wetenschap staat meer de theorievorming voorop en het begrijpen van bepaalde verschijnselen, nog los van enige toepassing.

De gebruikers van resultaten van formeel wetenschappelijke activiteit zijn met name wetenschappers van andere discipline. Empirische wetenschappen zijn op praktische 
toepassing gericht (zoals de technische wetenschappen die de praktische toepassing bestuderen van theoretisch-natuurkundig onderzoek). Het is misschien om bovenstaande redenen dat de accountingwetenschap de ontwikkelingen in de natuurkunde voor een deel aan zich heeft laten voorbijgaan. De vraag die in dit verband resteert, is: Dient in de accounting het klassieke op de natuurkunde gebaseerde model nog steeds het vertrekpunt te zijn van wetenschappelijk en praktisch handelen? In elk geval kan worden gesteld dat het accountingmodel kan worden verder verrijkt door inzichten over te nemen van ontwikkelingen in andere empirische wetenschappen zoals de sociologie en psychologie (Cooper en Kozmetsky, 1992:14). De behavioral accounting is hiervan een praktische uitwerking. In dit verband liggen raakvlakken op met name gebieden als (interpersoonlijke) communicatie, (prestatie)motivatie, cognitieve processen en (groeps)gedrag ${ }^{14}$. Daarentegen vormen triple-entry en momentum accounting uitbreidingen van het accountingmodel met resultaten van theoretisch-natuurkundig onderzoek. Derhalve een verrijking met formele inzichten.

\subsection{Samenvatting}

Recente literatuur en onderzoeksresultaten doen vermoeden dat de kwaliteit van de huidige management accountingsystemen tekortschiet. Een belangrijke oorzaak hiervan is zonder twijfel het (te) sterk gericht zijn van de accountingsystemen op de juridische voorschriften inzake de externe financiële berichtgeving. Hierdoor zijn de in het systeem opgeslagen gegevens voornamelijk op het afleggen van verantwoording gericht en daardoor retrospectief van aard. Objectiviteit, controleerbaarheid en betrouwbaarheid vormen in dit kader de centrale thema's en bases voor handelingen. Een dergelijke eenzijdige inslag gaat ten koste van de relevantie van de accounting in het licht van de bedrijfsbeheersing. Hiertoe dienen voor een belangrijk deel prospectieve gegevens te worden verzameld en opgeslagen. Triple-entry en momentum accounting kunnen in dit verband worden gezien als middelen tot het verhogen van de prospectieve waarde van accountingsystemen door in deze systemen gegevens op te slaan over de oorzakelijke ontwikkeling in de winstcapaciteit van het eigen vermogen van de onderneming.

Bij een beschrijving van een aantal aspecten van verleden, heden en toekomst in het recente denken in de management accounting onderscheidt Birnberg (1992:1-19) een drietal richtingen: een 'economics strand', een 'behavioral strand' en een 'management strand'. In de economische benadering zoals die met name in de jaren '50-' 80 is aangehangen, staat voorop de wijze waarop de problemen zijn aangepakt. Het gaat om

\footnotetext{
${ }^{14}$ Recente ontwikkelingen in de attributietheorie zijn van dit laatste een goed voorbeeld. In de autributictheorie wordt nagegaan hoe het handelen van mensen wordt beïnvloed door hun perceptie van wat andere mensen denken en menen.
} 
elegantie meer dan om relevantie. Het is een mechanistisch-deductieve benadering welke leidt tot normatieve besluitvormingsmodellen ${ }^{15}$. In de gedragsmatige benadering gaat het om accounting als een communicatiesysteem, een motivatiemiddel, een prestatiebeoordelingsmiddel en staan onderwerpen centraal als informatie-asymmetrie, perceptie, disfunctionele (re)acties, cultuur, politieke processen en persoonlijkheid. In de meer recente management-benadering gaat het om relevantie van de accountinggegevens. In deze gebruikers- en dus servicegerichte benadering komen ideeën voor onderzoek uit de praktijk ${ }^{16}$. Met name de discussie omtrent activity based costing is hiervan een gevolg.

Onder andere Flamholz wijst er op dat de relevantie die de management accounting uit het oog heeft verloren een gevolg is van het feit dat in het accountingonderzoek de statistische verwerking is geprioriteerd boven de relevantie van het onderzoek.

"...Managerial accounting has lost its relevance. This has occurred because of the academic culture of statistical rigor rather than relevance" (1992:21).

Johnson doet in zijn boek 'Relevance regained' (1992) een aantal concrete voorstellen om de management accounting uit het slop te halen. Hierbij ziet hij niet veel heil in het aanpassen van bestaande accountingsystemen, maar pleit hij voor een geheel andere benadering van het vakgebied. Deze benadering komt er op neer dat Johnson probeert de marketing in de accounting te integreren. Op treffende wijze schetst Johnson het spanningsveld tussen het transactiegerichte boekhouden en de produktgerichte accounting enerzijds en klantgericht-management anderzijds. Het volledig tevreden stellen van klanten is de sleutel voor het lange-termijn bedrijfssucces. Dit succes wordt bereikt door het in alle opzichten tevreden stellen van klanten, niet door het zoveel mogelijk verkopen van de produkten die volgens het accountingsysteem het meest winstgevend zijn. De doelstelling van een bedrijf is niet het realiseren van winst, maar het creëren van een klant. Winst volgt dan van zelf. Twee zaken zijn van groot belang: responsiviteit en flexibiliteit. Responsiviteit kan worden bereikt door het aanleggen van goede relaties met klanten, het personeel en leveranciers. Flexibiliteit in de produktie kan worden bereikt door het terugbrengen van het aantal variaties in de output. Het leiding geven aan bedrijfsprocessen op basis van accountinggegevens leidt er volgens Johnson toe dat het betreffende personeel de (gegevens over de) output en/of de processen manipuleert. Wanneer werknemers in de gelegenheid worden gesteld af te gaan op hun eigen waarne-

\footnotetext{
${ }^{15}$ Optimale voorraad- en bestelmodellen, nutsmaximalisatie-modellen en marginale analyses zijn in deze richting ontwikkeld. Deze modellen berusten vaak op oversimplificaties van de problemen die zich werkelijk in de praktijk aandienen.

${ }^{16}$ In de economische en gedragsmatige benadering gaan ideeèn van uit de wetenschap naar de praktijk. Deze benaderingen kunnen worden vergeleken met wat Bouma noemt de analytische methoden. De managementbenadering kan worden gelijkgesteld aan wat Bouma noemt de synthetische methode (1990:488).
} 
mingen en ervaring, leidt dit uiteindelijk tot betere resultaten. Johnson spreekt in dit verband van 'employee empowerment'. De hieruit voortkomende bottom-up krachten dienen garant te staan voor continue innovatie gericht op klantsatisfactie.

De management accounting wacht nog een spannende periode. Wat ooit het hoofdvak was binnen de bedrijfseconomie kan deze status herwinnen, indien binnen het management accountingsysteem op verantwoorde wijze voldoende creativiteit en flexibiliteit worden ingebracht en derhalve een cultuur van 'ondernemend administreren' wordt gecreëerd. Hierbij is een voortgaande emancipatie van de management accounting ten opzichte van de financial accounting onvermijdelijk (zie ook Bouma, 1990:488). 



\section{Gegevenskenmerken, conceptual framework en management accounting}

\subsection{Inleiding}

Wanneer met dit onderzoek wordt getracht de kwaliteit van management accountingsystemen te verbeteren, dient te worden aangegeven hoe een dergelijke kwaliteit kan worden beoordeeld. Zoals bij het beantwoorden van de vraag: 'welke van twee bedrijven het beste functioneert?', gebruik kan worden gemaakt van een aantal bedrijfseconomische hoedanigheden (met name liquiditeit, solvabiliteit en rentabiliteit), kan ook bij het beoordelen van een voorstel tot verbetering van een bestaand informatiesysteem de invloed van het nieuwe systeem op een aantal gegevens-kenmerken (gegevens-hoedanigheden) worden geanalyseerd. Vanuit deze invalshoek kan een management accountingsysteem worden gekwalificeerd door gebruik te maken van een raamwerk waarin een aantal van deze gegevensaspecten is opgenomen. Het vorm geven aan dit raamwerk is wellicht de belangrijkste fase in het ontwerpen van een management accountingsysteem (Wilson, 1991:84). De meeste onderzoeken op het gebied van het ontwerp van management accountingsystemen zijn gebaseerd op een benadering vanuit gegevenskarakteristieken.

\subsection{Relevante gegevenskenmerken}

Amigioni stelt dat een accountingsysteem kan worden gekenmerkt door het beschrijven van een achttal aspecten (1978:279-291):

1) 'Orientation'. Oriëntatie heeft onder andere betrekking op de vraag of de gegevens financieel of niet-financieel van aard zijn, of de gegevens op het verleden of op de toekomst betrekking hebben en op welke bedrijfsfunctie.

2) 'Formal responsibility'. Dit aspect betreft de vraag in hoeverre gebruik wordt gemaakt van financiële maatstaven ter beoordeling van het functioneren van (hoofden van) afdelingen.

3) 'Quickness'. Dit betreft de periodiciteit waarmee gegevens worden verstrekt (permanent, dagelijks, wekelijks, maandelijks).

4) 'Detail'. Bij dit aspect gaat het om de mate waarin gegevens per gewenste variabele kunnen worden geclusterd, bijvoorbeeld per produkt, per activiteit (functie) of per geografisch gebied.

5) 'Relevance'. Gegevens zijn relevant (bruikbaar) indien de systeemgebruiker hiermee betere beslissingen kan nemen.

6) 'Selectivity'. Gegevens zijn selectief indien de gebruiker alleen gegevens worden verstrekt die betrekking hebben op het gebied dat valt onder zijn verantwoordelijkheid. 
7) 'Control style'. De mate waarin en de wijze waarop systeemgegevens door het hogere management worden gebruikt voor het sturen en beoordelen van medewerkers.

8) 'Procedural rigidity'. Dit aspect betreft de vraag hoe vaak formele procedures worden veranderd ten behoeve van ad hoc informatievoorziening.

Jones gaat uit van het kwalificatie-model van Amigioni maar voegt hier een viertal kenmerken aan toe (Jones, 1986:292):

1) 'Accuracy'. Dit aspect heeft met name betrekking op de vraag in hoeverre de gegevens berusten op veronderstelling in plaats van op objectieve waarneming. In het algemeen gaat het hierbij om de vraag in hoeverre er fouten in het systeem kunnen sluipen.

2) 'Consultation'. De mate waarin medewerkers zelf betrokken zijn bij de gegevensinvoer (onder andere van belang voor potentiële gegevensmanipulatie). Amigioni vatte dit aspect onder 'control style'.

3) 'Availability as data base'. De mate waarin de systeemgebruiker toegang heeft tot 'ruwe' gegevens (onder andere van belang voor het vertrouwen dat de gebruiker in het systeem stelt).

4) 'Technology'. De technologie beschrijft de methoden en technieken waarvan gebruik wordt gemaakt ten behoeve van het informatiesysteem. Omdat Jones de aspecten 'relevance' en 'selectivity' zoals gebruikt door Amigioni samenvoegt, hanteert hij ten behoeve van het beschrijven van de gegevensstromen in een management accountingsysteem in totaal 11 kenmerken.

Chenhall en Morris daarentegen vinden dat de bruikbaarheid van een management accountingsysteem afhankelijk is van een viertal gegevenskenmerken (1986:19):

1) 'Scope'. Dit aspect heeft betrekking op het kenmerk 'oriëntatie van de gegevens' zoals bedoeld door Amigioni maar ook op de accuratesse zoals bedoeld door Jones.

2) 'Timeliness'. De periodiciteit en snelheid waarmee gegevens worden verstrekt.

3) 'Aggregation-level'. Hiertoe rekenen zij met name aspecten als de mate van detaillering, de bruikbaarheid van gegevens voor 'what-if'-analyses, de toepasbaarheid van gegevens in beslissingsmodellen zoals investerings- en voorraadmodellen en de beschikbaarheid van kosten-gegevens, opgedeeld in een constant en variabel deel.

4) 'Integration-level'. Dit aspect betreft met name gegevens over de invloed welke de te nemen beslissing heeft op de winstgevendheid van de betreffende afdeling, alsmede gegevens over de invloed welke door derden te nemen beslissingen zullen hebben op het verantwoordelijkheidsterrein van de systeemgebruiker.

Ahituv en Neumann, auteurs op het gebied van management informatiesystemen in het algemeen, stellen het volgende: 
"The pricipal categories of information system attributes are the following (see also Kleijnen [cha. 10 p. 7]:
1. Timeliness
2. Content
3. Format
4. Cost" (1986:60).

Bij 'timeliness' gaat het behalve om de frequentie van de berichtgeving met name ook om de tijd die er verstrijkt tussen het beschikbaar komen van een nieuw gegeven en het verwerken hiervan in het systeem (het aspect van de tijdigheid). In het geval dit interval vrij kort van duur is, is sprake van een real-time systeem. Onder 'content' vallen eigenschappen als 'accuracy', 'relevance', 'exhaustiveness', 'redundancy', en 'level of detail (aggregation level)'. 'Exhaustiveness' heeft betrekking op de vraag of alle relevante gegevens met betrekking tot een bepaald object voorhanden zijn. Binnen een systeem is sprake van redundancy indien meer gegevens worden verstrekt dan minimaal is vereist ${ }^{1}$. 'Format' refereert aan het gebruikte medium bij de gegevenspresentatie, het al dan niet beschikbaar zijn van grafische weergaven en de wijze waarop gegevens zijn geordend, bijvoorbeeld in een verticale of horizontale opstelling. Wanneer een informatiesysteem wordt gekarakteriseerd met behulp van genoemde attributen en zo diverse alternatieven kunnen worden gepresenteerd, is het vanzelfsprekend ook van belang hierbij 'kostenplaatjes' te formuleren ${ }^{2}$. In die zin kunnen ook de kosten van elk alternatief ('cost') als een gegevenskenmerk worden behandeld.

Gordon en Narayanan gaan in hun onderzoek naar de invloed op het ontwerp van management accountingsystemen van de mate van onzekerheid in de bedrijfsomgeving respectievelijk de organisatiestructuur uit van een drietal gegevens-dimensies: (1) externe oriëntatie, (2) de mate waarin niét-financiële gegevens van belang zijn en (3) de mate waarin ex ante gegevens van belang zijn (1983:39). Ook andere onderzoekers hebben op het belang van deze drie gegevens-karakteristieken voor het ontwerp van management accountingsystemen gewezen (zie bijvoorbeeld Dermer, 1973:515).

In menig accountingonderzoek wordt verwezen naar de gegevenscriteria zoals die door Kleijnen zijn opgesteld (zie Kandelin en Lin, 1992). Voor het beoordelen van de kwaliteit van het ontwerp van een informatiesysteem heeft Kleijnen een set van 11 gegevenskenmerken opgesteld (1980:80):

1) 'Timeliness': zie voor een beschrijving van dit aspect Ahituv en Neumann.

2) 'Accuracy': zie voor een beschrijving van dit aspect Jones.

\footnotetext{
'In het algemeen is ten behoeve van de controle op gegevens enige redundantie wenselijk, met name ten aanzien van sleutelgegevens.

${ }^{2}$ Gegevensverwerking is immers niet kosteloos. Anders gezegd: elke kostprijs heeft een kostprijs.
} 
3) 'Aggregation': zie voor een beschrijving van dit aspect Chenhall en Morris.

4) 'Report mode': hieronder vallen aspecten als lay-out, periodieke versus uitzonderingsrapportage en maatwerk- dan wel standaardrapporten.

5) 'Retention time': het gaat hier om de bewaartermijn van de gegevens.

6) 'Privacy and security': hierbij gaat het om aspecten als de beveiliging van de gegevens en afscherming van de toegang daartoe voor onbevoegden.

7) 'Reliability and recovery': de mate waarin de gegevens model staan voor de werkelijkheid die zij representeren ('reliability') en de wijze waarop de veiligstelling van gegevens middels back-ups is geregeld ('recovery').

8) 'Scope': zie voor een beschrijving van dit aspect Amigioni.

9) 'User-machine modes': dit aspect heeft betrekking op de interface tussen machine en mens, dus het grensvlak waarop zich de mens aan de machine voordoet (bijvoorbeeld ten aanzien van de commando-toetsen).

10) 'Flexibility': dit is de mate waarin het systeem zich in de tijd weet aan te passen aan veranderende informatiebehoeften welke in belangrijke mate wordt bepaald door de systeem-modulariteit.

11) 'Multiple-users': hierbij gaat het om de vraag in hoeverre het systeem rekening houdt met specifieke gedragskarakteristieken van de gebruikers en van de organisatie waarin het zal worden opgesteld.

Voor hun ontwerp van een voorraad-computermodel, gebaseerd op de 'events-approach', selecteerden Kandelin en Lin van de door Kleijnen voorgestelde criteria er vier: 'accuracy', 'report-mode', 'aggregation' en 'flexibility' (Kandelin en Lin, 1992:25). Zij voegden hieraan twee kenmerken toe zoals die in het accountingonderzoek van groot belang worden geacht: relevantie en kwantificeerbaarheid (zie ook Mock, 1976). Deze twee criteria worden eveneens door de American Accounting Association (AAA) genoemd voor het beoordelen van potentiële accountinggegevens. In het betreffende 'statement' komt de AAA tot een viertal criteria: (1) relevantie, (2) controleerbaarheid, (3) onpartijdigheid en (4) kwantificeerbaarheid (American Accounting Association, 1966:8).

\subsection{Het conceptual framework voor de financial accounting}

Veel van de hiervoor genoemde gegevenskenmerken vinden we terug in het in de Verenigde Staten door de Financial Accounting Standards Board (FASB) ontwikkelde conceptual framework (FASB, 1978-1985) ${ }^{3}$. Een conceptual accounting framework is een beschrijving van het samenhangend geheel van (1) de doelstellingen van de berichtge-

\footnotetext{
${ }^{3}$ De FASB definieert een conceptual framework als volgt: "a coherent system of interrelated objectives and fundamentels that can lead to consistent standards and that prescribes the nature, function, and limits of financial accounting and financial statements" (FASB, 1976b:2).
} 
ving, (2) van de overzichten die dienen te worden verstrekt, (3) van de kwalitatieve eisen waaraan de verstrekte gegevens dienen te voldoen, en (4) van de postulaten en principes (overwegingen) die dienen te worden gevolgd ${ }^{4}$. Wat de kwalitatieve, aan gegevens te stellen eisen betreft, voorziet dit conceptuele kader in een zekere hiërarchie (zie figuur 5.1). Kwalitatieve gegevenskenmerken worden in het FASB-framework 'qualitative characteristics' genoemd.

Economische randvoorwaarde in de hiërarchie van gegevenskenmerken is dat de baten van het informatiesysteem de kosten moeten overtreffen ('benefits $>$ costs'). Bovendien zullen alleen dié gegevens in het systeem worden opgenomen welke vermogen de beslissingen van de gebruiker te beïnvloeden ('threshold for recognition'). Dit wordt het beginsel van 'materiality' genoemd. Tot de kosten kunnen ook eventuele concurrentienadelen worden gerekend, met name in die gevallen waarin niet alle concurrerende partijen aan dezelfde externe publicatievoorschriften zijn gebonden (Kirk, 1991:99).

'Understandability' verlangt dat de verstrekte gegevens door de gemiddelde gebruiker (is dit de 'verstandige leek'?) kunnen worden begrepen. 'Decision usefulness' geeft aan dat de verstrekte gegevens bruikbaar moeten zijn voor het nemen van beslissingen.

'Relevance' heeft betrekking op de bruikbaarheid van de gegevens voor de oplossing van het probleem waarvoor de gebruiker zich ziet gesteld. 'Predictive value' is de waarde van de verstrekte gegevens bij het formuleren van toekomstverwachtingen. 'Feedback value' is de bruikbaarheid van de verstrekte gegevens bij het beoordelen van in het verleden uitgesproken toekomstverwachtingen. 'Timeliness' betreft de tijdigheid van de verstrekte gegevens. Gegevens die te laat beschikbaar komen, zijn niet meer relevant. 'Reliability' heeft betrekking op de mate waarin de gegevens betrouwbaar zijn, of anders gezegd hoe getrouw de accountinggegevens de werkelijkheid weergeven. 'Verifiability' (vaak ook genoemd 'objectivity') stelt de vraag of de juistheid van de verstrekte gegevens objectief kan worden gecontroleerd. Dit komt tot uitdrukking in de mate van overeenstemming in de uitkomsten die zou bestaan indien verschillende personen de accountingwerkzaamheden zouden hebben uitgevoerd (Ijiri en Jaedicke, 1966:483). 'Neutrality' betekent dat de verstrekte gegevens objectief (en dus niét suggestief) moeten zijn. 'Representational faithfulness' heeft betrekking op de mate waarin de verstrekte gegevens datgene weergeven wat ze beogen weer te geven. 'Comparability' geeft de mogelijkheid verstrekte gegevens te vergelijken met een vorige periode van de zelfde onderneming of met vergelijkbare ondernemingen in de zelfde periode.

\footnotetext{
${ }^{4}$ Een postulaat (als een niet verifieerbare veronderstelling) is bijvoorbeeld de 'going-concern'-aanname of de aanname van een bepaald tijdvak als verslagperiode. Uit deze basisveronderstellingen kunnen vervolgens accountingprincipes worden afgeleid. Een accountingprincipe is een algemene richtlijn voor de praktijk bij het opslaan en verwerken van financiële gegevens, zoals het matching-principe en het voorzichtigheids-beginsel.
} 
Het kunnen maken van een vergelijking is van belang voor het geven van een zodanig inzicht dat een verantwoord oordeel kan worden gevormd omtrent het vermogen, etcetera (vergelijk BW 2:362, lid 1). Zonder het kunnen maken van een vergelijking is verantwoorde oordeelsvorming onmogelijk. Vergelijkbaarheid is daarom belangrijker dan inzicht (Brink, 1991:3).

Figuur 5.1 Het FASB-model.

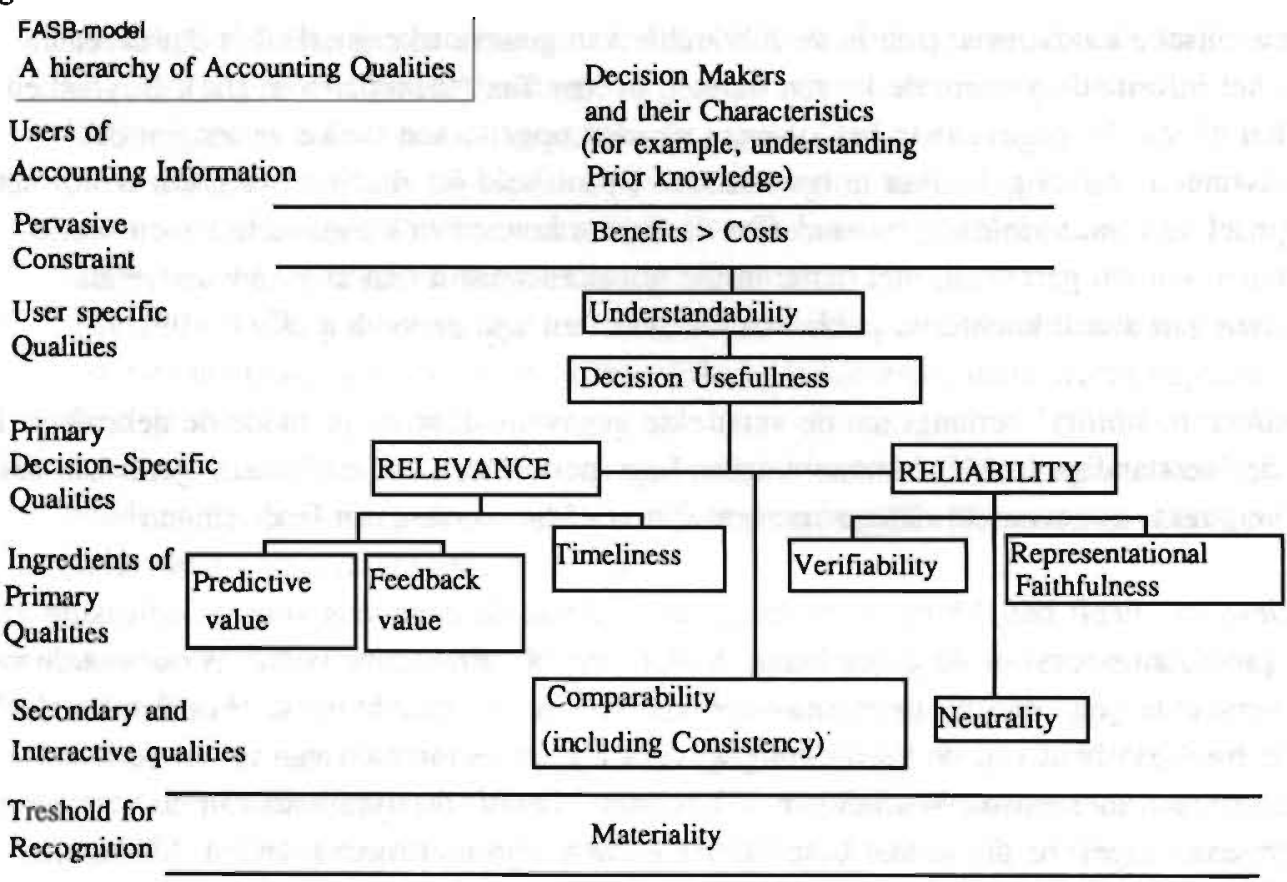

Er is sprake van 'consistency' wanneer de verstrekte gegevens, in de tijd gezien, berusten op dezelfde grondslagen en principes. Vanzelfsprekend is dit van groot belang voor de vergelijkbaarheid.

Het conceptual framework van het IASC (International Accounting Standards Committee) komt in grote lijnen met het FASB-model overeen (Agrawal et all, 1989:244) ${ }^{5}$. Het Accounting Standards Committee (ASC) in Engeland heeft het IASC-model overgenomen

\footnotetext{
${ }^{5}$ Mct name de beginselen 'substance over form' en 'voorzichtigheid' alsmede het aspect 'volledigheid' worden in het IASC-model expliciet genoemd. Behalve voor het evenwicht tussen kosten en baten wordt in dit model ook aandacht gevraagd voor het evenwicht tussen de diverse kwalitatieve gegevenskenmerken. Anders gezegd: het opvoeren van de kwaliteit van het ene kenmerk kan ten koste gaan van de kwaliteit van een ander kenmerk.
} 
(het model is alleen nog nader gedetailleerd). In het IASC/ASC-model worden de kwalitatieve gegevenskenmerken als volgt gedefinieerd:

"Qualitative characteristics are the attributes that make the information provided in the financial statements useful for users. The four principal qualitative characteristics are understandability, relevance, reliability and comparability" (IASC, 1989:15).

Als basiskenmerken van gegevens worden beschouwd: relevantie, reliability en de relatie tussen deze twee kenmerken.

"... a better insight can be gained by considering the interrelation between these characteristics and recognising that relevance and reliability are the key characteristics that any piece of financial information must have to be useful" (Accountancy, 1991:101).

Ter vergelijking is hierna ook het door het (I)ASC voorgestelde model voor gegevenskenmerken opgenomen (zie figuur 5.2). De meeste hierin opgenomen kenmerken komen tevens voor in het FASB-model. 'Confirmatory value' komt overeen met 'feedback value'. Het kenmerk 'substance over form' geeft aan dat voor het al dan niet verslag doen over transacties en/of gebeurtenissen de economische omstandigheden en niét de juridische bepalend zijn. 'Prudence' betekent dat bij het schatten van toekomstige onzekere gebeurtenissen de nodige voorzichtigheid wordt ingebouwd, zodat kosten en/of verplichtingen niet worden onderschat en opbrengsten en/of activa niet worden overschat.

Expliciet (in paragraaf 40) wijst het (I)ASC op 'trade-offs' die kunnen bestaan tussen de onderscheiden gegevenskenmerken, dat wil zeggen: onderlinge afhankelijkheid der kenmerken. Het aspect 'neutraliteit' bijvoorbeeld wordt geschaad door toepassing van 'voorzichtigheid' en het aspect 'volledigheid' door het streven naar 'tijdigheid'. Het is de taak van het management een evenwichtige verhouding aan te brengen tussen de diverse gegevenskenmerken. In dit verband doet zich de vraag voor of, waar en in welke mate deze verhouding anders ligt wanneer het gaat om management accounting in plaats van financial accounting. In hoofdstuk 6 worden de resultaten besproken van een empirisch onderzoek naar deze verhouding.

Voor management accounting ontbreekt op dit moment een soortgelijk 'conceptual framework'. Anthony ziet dit als een bijzonder gemis bij de huidige management accounting (1991:8). Omdat het in het voor de financial accounting bestaunde conceptual framework echter gaat om vrij algemene eisen te stellen aan accountinggegevens, kan dit raamwerk wellicht ook dienen bij de management accounting. Waarschijnlijk worden in de management accounting andere accenten gelegd ten aanzien van de gestelde kenmerken, dat wil zeggen de wegingsfactoren van de kenmerken zullen verschillen. Onder 
Figuur 5.2 Het (I)ASC-model.

The Qualitative Characteristics of Accounting Information

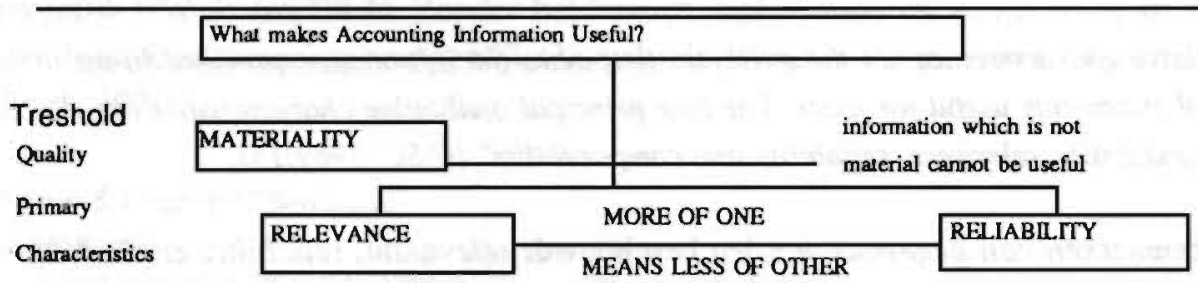

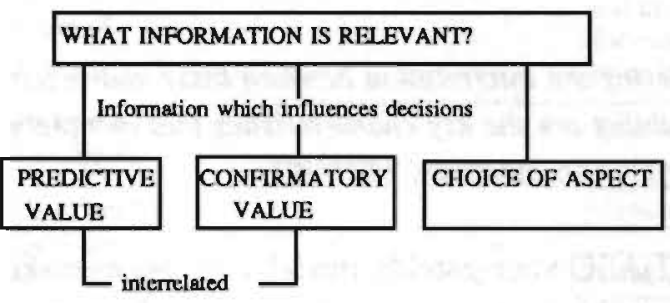

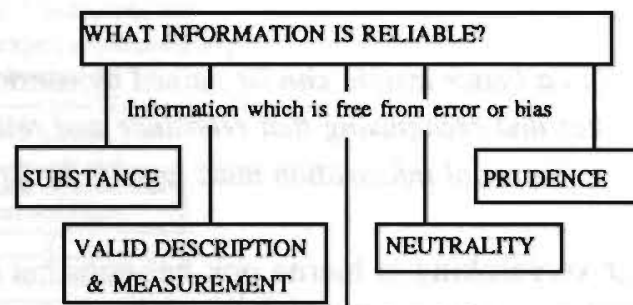

COMPLETENESS

relevant information __ usefull information __ reliable information

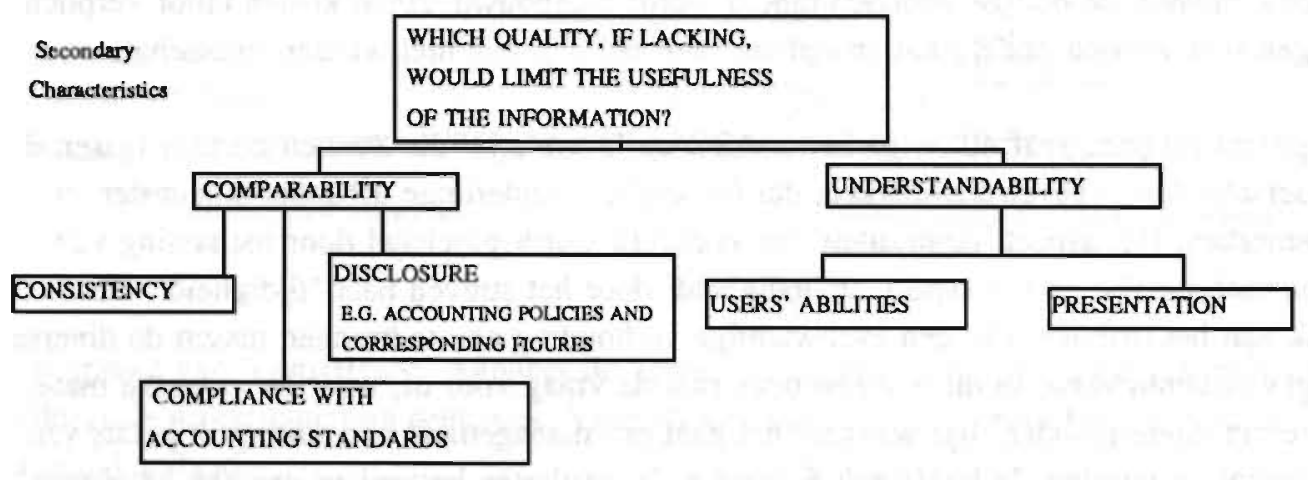

TRADE OFFS




'Users and Their Information Needs' vindt in het IASC-raamwerk als volgt een verwijzing naar management accounting plaats:

"Management is also interested in the information contained in the financial statements even though it has access to additional management and financial information that helps carry out its planning, decision-making and control responsibilities. Management has the ability to determine the form and content of such additional information in order to meet its own needs. The reporting of such information, however, is beyond the scope of this framework. Nevertheless, published financial statements are based on the information used by management about the financial position, performance and changes in financial position of the enterprise" (IASC, 1989:10).

\subsection{Conceptual framework en de structuur van het ontwerp van een management accountingsysteem}

In tegenstelling tot financial accounting dat zich richt op het verstrekken van algemene (standaard) financiële overzichten, dient in management accounting veeleer een contingente (dit is een situatie-afhankelijke) benadering te worden gevolgd. Afhankelijk van de probleemsituatie dient aan de financieel-economische gegevens op een bepaalde wijze inhoud te worden gegeven. Deze benadering komt het beste tot uitdrukking in wat J.M. Clark noemde 'different costs for different purposes' (1947:175). Een andere algemene pijler waarop het (her)ontwerp van een management accountingsysteem dient te worden gebaseerd, komt uit de organisatie-literatuur. Een adagium in dit verband is van $A$. Chandler (1966): 'structure follows strategy'. Concreet betekent dit dat de organisatiestructuur een afgeleide dient te zijn van de door de onderneming uitgestippelde strategie. Vervolgens wordt algemeen aangenomen dat de wijze waarop het management de interne organisatie heeft afgestemd op de strategie, bepalend is voor het ontwerp van het management control- en accountingsysteem.

"... accounting exists within a business primarily to facilitate the development and implementation of business strategy" (Shank en Govindarajan, 1989:xi).

Van de Poel over de relatie organisatiestructuur/accountingsysteem:

"De wijze waarop men de organisatie structureert, bepaalt de contouren van de interne berichtgeving" (Van de Poel, 1991:202).

Ook Miles en Snow (1978) bevestigen de noodzaak van deze onderlinge afstemming. 
Waterhouse en Tiessen merken over de afstemming van het management accountingsysteem op de organisatie, het volgende op:

"Whether explicitly recognized or not the efficient design of the management accounting system must recognize organization variables" (1978:71).

Organisatievariabelen hebben met name betrekking op de organisatiegrootte, de toegepaste produktietechnologie en op de omgeving van de organisatie.

Strategie is een multidimensionaal begrip en het kan bijvoorbeeld zowel op de marketing, op de produktie als op de bedrijfsorganisatie betrekking hebben. Het management accountingsysteem dient wijzigingen in deze beleidsvelden daar waar nodig te volgen. Sommige organisatiedeskundigen zoals Miles en Snow stellen dat de kansrijkheid van een strategie wordt bepaald door de wijze van implementatie (onder andere via het management controlsysteem) en de afstemming op de interne (on)mogelijkheden (Miles en Snow, 1978:18). Daarentegen stelt onder andere Porter dat een onderneming haar strategie dient af te stemmen op haar omgeving. Dit betekent dat in geval van dynamische industrieën innovatieve strategieën zullen moeten worden gevolgd, terwijl in geval van redelijk stabiele markten een meer traditionele strategie voor de hand ligt waarbij het accent ligt op kostenminimalisatie, kwaliteit en service (Porter, 1980; 1985). In dit verband stellen Miller en Friessen in een onderzoek negatieve correlatie vast tussen innovatie en control (1982:26). Deze bevinding komt overeen met die van Thompson: innovatie-strategie en intensieve administratieve controle zijn onverenigbaar (1965:19). Khandwalla onderzocht in 1972 de relatie tussen de mate waarin concurrentie wordt waargenomen en de mate waarin van (geavanceerde) accounting controlsystemen gebruik wordt gemaakt. Hij stelde positieve correlatie vast (1972:285). Een goede congruentie tussen strategie en management accountingsysteem lijkt van groot belang. Hiromoto verklaart het succes van de Japanse management accounting uit deze congruentie (1988:24).

Een goed functionerend management control- en accountingsysteem is niet enkel van belang voor het succesvol implementeren van strategieën. Het kan tevens de effectiviteit van deze strategieën vergroten (Cunningham, 1992:97) en derhalve is er sprake van een recursieve relatie tussen strategie en (accounting) control. Dit is tevens de conclusie van het onderzoek van Gordon en Narayanan. Bovendien stelden deze auteurs vast dat de organisatiestructuur minder van belang was voor het ontwerp van het management accountingsysteem dan de waargenomen onzekerheid in de bedrijfsomgeving. Naarmate deze onzekerheid toenam, nam de behoefte aan externe, niet-financiële en ex ante gegevens toe waarbij bovendien de tendens naar een niét-mechanistische organisatiestructuur wairneembaar was.

Nadrukkelijk stellen Gordon en Narayanan dat management accountingsystemen niet enkel op de organisatiestructuur moeten worden afgestemd en dus wat dit betreft reactief 
zijn, maar dat dezelfde systemen ook veranderingen in de organisatie-structuur teweeg kunnen brengen en derhalve een proactieve functie kunnen vervullen (Gordon en Narayanan, 1984:43-44).

Simons bevestigt met zijn onderzoek naar de relatie 'strategie en accounting controlsysteem' wat Ashby als 'requisite variety' aanduidde (Ashby, 1956:86): naarmate de onzekerheid in de bedrijfsomgeving toeneemt zal het betreffende management intensiever gebruik maken van het management controlsysteem (Simons, 1987:358-359).

Beide eerder genoemde pijlers, (1) 'different costs for different purposes' en (2) 'structure follows strategy', vereisen van het management accountingsysteem het nodige adaptieve vermogen. Enkel wanneer het management accountingsysteem hieraan tegemoet kan komen, blijft het bij de tijd en bezitten de aan dit systeem te ontlenen gegevens voldoende beslissings-relevante waarde. Alleen in dit geval is het management accountingsysteem functioneel en is het 'a vehicle for strategy implementation' (Porter, 1980).

Het in het kader van de externe verslaglegging door de FASB ontwikkelde 'conceptual framework' (FASB, 1978, 1980) ${ }^{6}$ kan waarschijnlijk ook goed worden gebruikt bij het globaal verder structureren van het interne berichtgevingssysteem.

Uitgangspunt van het conceptuele kader is het bepalen van de doelstellingen die met de interne berichtgeving worden nagestreefd. Dit komt neer op het inventariseren van de bestaande informatiebehoeften (informatie-analyse). In het algemeen betreft het in de management accounting gegevens voor de beslissingsondersteuning, de beheersing en de (interne) verantwoording. Per organisatie kunnen hierbij de prioriteiten verschillen, afhankelijk van bijvoorbeeld de bedrijfsgrootte, de strategische positie, de bedrijfstak, de bedrijfsorganisatie en/of de bedrijfscultuur? .

Vervolgens kan een aantal gegevenskenmerken via het conceptuele kader worden geïdentificeerd en nader uitgewerkt (dit is systeemanalyse), zoals relevantie en getrouwheid en hiervan afgeleide kwaliteiten zoals tijdigheid en controleerbaarheid.

Het is te verwachten dat bij management accounting andere accenten worden gelegd op de onderscheiden gegevenskenmerken dan bij financial accounting. Bijvoorbeeld, in het kader van de interne berichtgeving zal de kwaliteit 'predictive value' relatief gezien van groter belang zijn dan in de externe verslaglegging. Dit betekent waarschijnlijk dat op de aspecten 'verifiability' en 'neutrality' (en dus op 'reliability') moet worden toegegeven. Uitkomst van de systeemanalyse kan zijn dat binnen de management accounting een

\footnotetext{
${ }^{6}$ Of het hierop gebaseerde (I)ASC-model.

${ }^{7}$ Het feit dat tockomstige gebruikers vaak onvoldoende in staat zijn hun informatiebehoeften te specificcren, is een belangrijke oorzaak van het feit dat informatiesystemen niet naar tevredenheid functioneren (zie Oonincx, 1982).
} 
aantal gescheiden systemen dient te worden opgezet, dit gezien de verscheidenheid van de taken die men met behulp van deze systemen tracht te vervullen (zie voor deze taken hoofdstuk 2). Bijvoorbeeld, de functie van het accountingsysteem in het kader van de verantwoording staat wat de 'scope' van de gegevens betreft haaks op de functie van beslissingsondersteuning (in mindere mate op de beheersingsfunctie). In het kader van de beslissingsondersteuning moeten met name gegevens worden geadministreerd over de steeds veranderende en met onzekerheid omgeven werkelijkheid waarop de beslissingen betrekking hebben. Dit betekent dat relatief veel verwachte gegevens in het systeem zullen moeten worden ingevoerd, dat wil zeggen, gegevens over transacties en/of gebeurtenissen waarvan de gevolgen niet exact bekend zijn en waarvan de berekening vaak pas na subjectieve interpretatie van omgevingsconstellaties kan plaatsvinden. In het kader van de verantwoording worden in hoofdzaak gerealiseerde gegevens over uitgevoerde transacties in het systeem vastgelegd. Het is aldus moeilijk, zo niet onmogelijk deze naar aard zeer verschillende taken van management accounting in één enkel unificerend systeem onder te brengen. Recente literatuur doet dit bevestigen.

"One Cost System isn't enough. No single system can adequately answer the demands made by the diverse functions of cost systems" (Kaplan, 1988:61-66).

"Het grote probleem - we stelden dat al eerder vast - is het feit dat er verschillende doelen moeten worden gediend met hetzelfde informatiesysteem" (Van de Poel, 1991:203).

Dat beslissingsondersteunende functie en verantwoordings-functie moeilijk zijn te verenigen in één accountingfunctie zou, zoals gezegd, ertoe kunnen leiden twee afzonderlijke (alhoewel aan elkaar gekoppelde) systemen te onderhouden. (Kosten) Technisch behoeft dit bij het beschikbaar zijn van geavanceerde computersystemen niet op bijzondere problemen te stuiten.

Globale verschillen tussen het externe en inteme berichtgevingssysteem (financial accounting respectievelijk management accounting) kunnen met behulp van het thans beschikbare kader worden weergegeven. In tabel 5.1 is op basis van eigen kennis, ervaring en intuïtie het gegevenskenmerk ingedeeld in dát berichtgevingssysteem waarin waarschijnlijk aan dit kenmerk meer belang wordt gehecht dan in het andere systeem. Waar dominantie vermoedelijk minder evident is, is het gegevenskenmerk ondergebracht bij beide accountingsystemen.

Ondanks de welhaast onlosmakelijke band tussen 'relevance' en 'reliability' zou men deze tabel zo moeten interpreteren dat in het kader van de interne berichtgeving de relevantie van de verstrekte gegevens belangrijker is dan de (objectief controleerbare) 
betrouwbaarheid ${ }^{8}$. Wanneer nu het management accountingsysteem wordt opgezet vanuit een (hoofdzakelijk) financial accounting perspectief, is de irrelevantie en/of irrealiteit van dit systeem zoals recente literatuur suggereert, niet onverwacht (zie onder andere Johnson en Kaplan, 1987; Johnson, 1990).

Tabel 5.1 Financial en management accounting en gegevenskarakteristieken.

\begin{tabular}{|l|l|l|}
\hline \multicolumn{2}{|l|}{$\begin{array}{l}\text { financial } \\
\text { accounting }\end{array}$} & $\begin{array}{l}\text { management } \\
\text { accounting }\end{array}$ \\
\hline \multicolumn{2}{|l|}{} \\
\hline RELEVANCE & \multicolumn{1}{|l|}{} \\
\hline 1.timeliness & $\mathrm{X}$ \\
\hline 2.predictive value & $\mathrm{X}$ \\
\hline 3.feed-back value & $\mathrm{X}$ \\
\hline RELIABILITY & $\mathrm{X}$ & $\mathrm{X}$ \\
\hline 4.verifiability & $\mathrm{X}$ & $\mathrm{X}$ \\
\hline 5.neutrality & $\mathrm{X}$ \\
\hline $\begin{array}{l}\text { 6.representational } \\
\text { faithfulness }\end{array}$ & $\begin{array}{l}\text { RELEVANCE/ } \\
\text { RELIABILITY }\end{array}$ & $\mathrm{X}$ \\
\hline 7.comparability & $\mathrm{X}$ \\
\hline
\end{tabular}

In het geval het wenselijk is binnen het management accountingsysteem meerdere gescheiden systemen te gebruiken, zou dit wat de in hoofdstuk 2 genoemde taken en in dit hoofdstuk onderscheiden gegevenskenmerken betreffen, het volgende beeld kunnen opleveren (zie tabel 5.2).

Vergelijking van tabel 5.1 met tabel 5.2 laat zien dat de verantwoordingsfunctie van de management accounting voor zover het de gegevenskenmerken betreft, overeenkomt met de gegevenskenmerken in de financial accounting. Het zijn in hoofdzaak de beslissingsondersteunende en beheersingsfunctie van de management accounting die in het gedrang komen wanneer het gehele management accountingsysteem wordt opgezet van uit een financial accounting invalshoek.

\footnotetext{
${ }^{8}$ Interessant in dit verband zijn de bevindingen van Stamp die de leden van het Engelse Accounting Standards Committee een lijst voorlegde met een twintigtal kwalitatieve gegevenskenmerken en vervolgens verzocht hierin cen voorkeursvolgorde aan te brengen. Hierbij scoorden 'relevance', 'substance' en 'materiality' het hoogst en 'comparability', 'neutrality' ('freedom from bias') en 'full disclosure' relatief laag (1982:123-132).
} 
Tabel 5.2 Management accountingfuncties en gegevenskarakteristieken.

\begin{tabular}{|c|c|c|c|}
\hline \multicolumn{4}{|c|}{ MANAGEMENT ACCOUNTINGSYSTEEM } \\
\hline & $\begin{array}{l}\text { beslissings- } \\
\text { ondersteuning }\end{array}$ & beheersing & verantwoording \\
\hline \multicolumn{4}{|l|}{ RELEVANCE } \\
\hline 1.timeliness & $\mathbf{X}$ & $\mathrm{x}$ & \\
\hline 2.predictive value & $\mathbf{X}$ & & \\
\hline 3.feed-back value & & $\mathbf{X}$ & $\mathbf{X}$ \\
\hline \multicolumn{4}{|l|}{ RELIABILITY } \\
\hline 4.verifiability & & & $\mathrm{X}$ \\
\hline 5.neutrality & $\mathrm{X}$ & $\mathrm{X}$ & $X$ \\
\hline $\begin{array}{l}\text { 6.representational } \\
\text { faithfulness }\end{array}$ & $X$ & $\mathrm{X}$ & $\mathrm{x}$ \\
\hline \multicolumn{4}{|l|}{$\begin{array}{l}\text { RELEVANCEI } \\
\text { RELIABILITY }\end{array}$} \\
\hline 7.comparability & $X$ & $\mathrm{X}$ & $\mathrm{X}$ \\
\hline
\end{tabular}

\subsection{Accounting measurement}

Met het geconcipieerde algemene kader waarbinnen het management accountingsysteem zal dienen te functioneren als uitgangspunt, dient te worden vastgesteld:

a) over welke objecten gegevens dienen te worden verzameld,

b) welke gegevens die objecten het beste beschrijven

en

c) welke bewerkingen op die gegevens nodig zijn ten einde tot het gewenste resultaat te komen (dit alles noemt men wel het technisch systeemontwerp) ${ }^{9}$.

Het accountingsysteem zal de invloed op deze objecten dienen te analyseren van de processen en gebeurtenissen die zich in en rondom het betreffende bedrijf voltrekken. Dit

\footnotetext{
${ }^{9}$ Op basis van het IASC-conceptual framework kan worden afgeleid dat in financial accounting deze administratieve objecten betreffen (1) 'financial position', (2) 'performance' en (3) 'changes in financial position'. De gegevens waarmee deze objecten kunnen worden beschreven worden uiteengezet in een apart hoofdstuk 'The Elements of Financial Statements'. "The elements directly related to the measurement of financial position in the balance sheet are assets, liabilities and equity. The elements directly related to the measurement of performance in the income statement are income and expenses. The statement of changes in financial position usually reflects income statement elements and changes in balance sheet elements; accordingly this framework identifies no elements that are unique to this statement" (IASC, 1989:20).
} 
is wat men noemt 'accounting measurement ${ }^{10}$ ' en komt neer op het bepalen van de geldelijke effecten welke voorgenomen en/of uitgevoerde transacties $^{11}$ en overige gebeurtenissen hebben voor het onderscheiden administratieve object. In het kader van het 'accounting measurement' dient antwoord te worden gegeven op de volgende vraag (vragen):

Voor (1) wie wordt (2) wanneer en (3) waartegen (4) waarop geadministreerd? Needles, Anderson, en Caldwell beschrijven dit als volgt:

"The accountant must answer four basic questions to make an accounting measurement:

1. What is to be measured?

2. When should the measurement occur?

3. What value should be placed on what is measured?

4. How is what is measured to be classified?" (1988:13).

Beantwoording van de gestelde vraag (vragen) brengt ons bij een aantal standpunten dat moet worden ingenomen met betrekking tot accountingpostulaten en -conventies en derhalve bij algemeen aanvaarde grondslagen voor de verslaglegging.

Aspect 1 ('wie'?) handelt over de gebeurtenissen welke de accountant dient te registreren en brengt ons bij het basisprincipe van accounting, het entity concept. Voor accountingdoeleinden wordt een bedrijf als een afzonderlijke eenheid behandeld, los van zijn klanten en schuldeisers en zelfs los van zijn eigenaren. Het bedrijf als zelfstandig geheel kan bezittingen en schulden hebben, afgescheiden van die van de eigenaren. Het saldo van bezittingen en schulden van het bedrijf beschouwt men als een schuld aan de eigenaar (eigenaren). Deze conceptie, wel 'zaak-theorie' genoemd, maakt het mogelijk een aantal logische regels af te leiden voor het debiteren en crediteren van grootboekrekeningen. De grenzen die met het 'entity concept' worden getrokken, stellen de accountant in staat een onderscheid te maken tussen gebeurtenissen ('financiële feiten') waarvan de gevolgen wél en gebeurtenissen waarvan de gevolgen niét dienen te worden geregistreerd. Aspect 2 ('wanneer'?) handelt over het moment waarop een gebeurtenis dient te worden geadministreerd. Dit wordt 'the recognition problem' genoemd ${ }^{12}$.

Het derde aspect ('waartegen'?) handelt over het bedrag dat bij de te registreren transacties dient te worden opgenomen ('money measurement'), terwijl met het laatste aspect

\footnotetext{
${ }^{10}$ Wolk, Francis en Tearney definiëren 'accounting measurement' als volgt "The assignment of numbers to the atributes or properties of objects being measured, which is exactly what accountants do" (1992:9).

"Horngren en Sundem omschrijven een transactie als: "Any event that both affects the financial position of an entity and can be reliably recorded in money terms. Transaction analysis is the nucleus of accounting" (1990:8).

${ }^{12}$ In het IASC-conceptual framework wordt aan dit beginsel een afzonderlijk hoofdstuk gewijd: 'Recognition of the Elements of Financial Statements' (IASC, 1989:28).
} 
('waarop'?) het classificatie-probleem wordt bedoeld, zijnde de elementen waaruit de financiële positie en de periodieke financiële prestatie van de onderneming worden geacht te bestaan (het vraagstuk van de rubricering). In dit verband heeft de FASB een 10-tal wederzijds afhankelijke items gedefinieerd ten behoeve van de externe berichtgeving. Deze items betreffen 'Assets', 'Liabilities', 'Equity', 'Investments by owners', 'Distributions to owners', 'Comprehensive income', 'Revenues', 'Expenses', 'Gains', 'Losses' (FASB, 1980). Deze items, waarmee ontwikkelingen in de financiële positie van de onderneming kunnen worden beschreven, bepalen de inhoud van de financiële berichtgeving. Intern zal naast genoemde items behoefte kunnen bestaan aan gegevens over ándere items (zoals concurrenten) en/of aan een andere rangschikking van aanwezige gegevens met betrekking tot de hiervoor genoemde items (zoals gegevens per klant of per afdeling). Samengevat zijn de vraagstukken ten aanzien van accounting measurement de volgende:

Tabel 5.3 Accounting measurement.

\begin{tabular}{|l|l|}
\hline \multicolumn{2}{|c|}{ ACCOUNTING MEASUREMENT } \\
\hline \multicolumn{2}{|c|}{} \\
\hline 1.wie? & entity concept \\
\hline 2.wanneer? & recognition \\
\hline 3.waartegen? & money measurement \\
\hline 4.waarop? & classificatie naar item \\
\hline
\end{tabular}

De FASB-voorstellen geven verder weinig inhoudelijke richtlijnen voor het accountingproces. Onvermeld blijft naar welke gezichtspunten de genoemde items dienen te worden geadministreerd ${ }^{13}$. Wat zijn

"the atributes or properties of objects being measured"? (Wolk, Francis en Tearney, 1992:9).

Is dit de plaats?, de hoeveelheid?, de waarde?, de gebruikstermijn?, het verbruik?, de datering? ...? Met andere woorden: de te administreren items hebben verschillende dimensies en de accountant dient een keuze te maken welke van die dimensies zullen worden geadministreerd. Dit aspect komt niét tot uitdrukking in de vraag die eerder is opgeworpen ten aanzien van 'accounting measurement'. Een met dit aspect aangevulde vraag is: Voor (1)wie wordl (2)wanneer, (3)waartegen, (4)waarop en (5)waarnaar geadministreerd?

Op basis van het aldus verkregen 'accounting measurement'-model kan een fundamentele analyse worden gemaakt van het in een concrete situatie meest adequate accountingsys-

${ }^{13}$ Het antwoord op deze vraag brengt ons nader tot het concept van triple-entry accounting. 
teem. Algemeen onderscheidt men ten behoeve van de registratie als onderdeel van de accountingwerkzaamheden een enkelvoudig en tweevoudig (ook genoemd 'dubbel') boekhoudsysteem. Beide zijn commerciële stelsels met als centraal object van administratie het (eigen) vermogen van de onderneming ${ }^{14}$. In een enkelvoudig boekhoudsysteem is de dimensie van het vermogen die wordt geadministreerd de hoeveelheid of samenstelling ${ }^{15}$. Geregistreerd wordt uit hoeveel stuks de diverse bezittingen en schulden zijn samengesteld. In een tweevoudig boekhoudsysteem worden van het vermogen twee dimensies geadministreerd, zowel de samenstelling als de waarde (of omvang of groot$t e)^{16}$.

In een drievoudig, drie-dimensionaal of triple-entry accountingsysteem worden van het eigen vermogen drie dimensies geadministreerd: zowel de samenstelling, als de (mutatie in de) omvang als de (mutatie in de) winstcapaciteit. In tabel 5.4 zijn genoemde dimensies nogmaals samengevat.

Tabel 5.4 Boekhoud-/accountingstelsels en dimensies van het object van administratie.

\begin{tabular}{|l|l|l|}
\hline stelsel & $\begin{array}{l}\text { object van } \\
\text { administratic }\end{array}$ & $\begin{array}{l}\text { geadministreerde dimensie van het } \\
\text { object }\end{array}$ \\
\hline enkelvoudig & vermogen & $\begin{array}{l}\text { samenstelling } \\
\text { (hoeveelheid) }\end{array}$ \\
\hline tweevoudig & vermogen & $\begin{array}{l}\text { samenstelling én } \\
\text { omvang (waarde) }\end{array}$ \\
\hline drievoudig & vermogen & $\begin{array}{l}\text { samenstelling én } \\
\text { omvang én } \\
\text { winstcapaciteit }\end{array}$ \\
\hline
\end{tabular}

De winstcapaciteit van het eigen vermogen uitgedrukt als een voorraadgrootheid, door ljiri aangeduid als 'income momentum', is

\footnotetext{
${ }^{14}$ Met het object 'vermogen' kan zowel de financièle positie als de wijziging daarin ('performance') worden beschreven.

${ }^{15}$ Alhoewel in een enkelvoudig boekhoudsysteem in principe uitsluitend aantallen (hoeveelheden) worden geregistreerd, vindt periodiek meestal omrekening van de hoevecheden in geld plaats. Deze omrekening maakt de diverse vermogensbestanddelen dimensioneel homogeen zodat hierop bewerkingen mogelijk worden (zoals optellen en aftrekken). Zic ook de opmerkingen in hoofdstuk 1 bij de bespreking van het klassieke accounting-model.

${ }^{16}$ Het zijn deze twee dimensies, samenstelling en omvang, die ook in bijvoorbeeld financieringsvraagstukken worden aangehouden bij hel 'meten' van het eigen vermogen. "Men duidt de vaststelling van de grootte en de samenstelling van het eigen vermogen wel aan met de term kapitalisatie van het eigen vermogen, veelal kortweg kapitalisatie genocmd" (Bouma, 1988:271).
} 
"the tendency for revenues and expenses to recur whatever the reasons for recurrence might $b e^{\prime \prime}(1989: 44)$.

Veranderingen in de winstcapaciteit worden verklaard uit winstkrachten. Wanneer eenmaal, stel in periode to, het ontstaan van een winstkracht (positief dan wel negatief) erkend en administratief is vastgelegd, is het vervolgens administreren van de daaruit voortvloeiende kasstromen die in de perioden $\mathrm{tl}$-tn plaatsvinden niet of nauwelijks relevant bij het beoordelen van het functioneren van het bedrijf(smanagement) in de perioden tl-tn.

Conventionele accountingsystemen zijn evenwel gericht op het administreren van deze kasstromen, terwijl het ontstaan van nieuwe winstkrachten en het tenietgaan van bestaande winstkrachten worden genegeerd. Wanneer bijvoorbeeld door het bedrijfsmanagement met de vakbonden een salarisverhoging wordt overeengekomen, ontstaat op dat moment een negatieve winstkracht waardoor de winstcapaciteit van het eigen vermogen afneemt. In geval van triple-entry en momentum accounting worden het ontstaan alsmede de financiële consequenties van deze krachten ('drivers') geadministreerd. In een conventioneel accountingsysteem daarentegen, worden enkel de uit hoofde van deze contractuele afspraken later in de tijd voortvloeiende betalingen geregistreerd. In het kader van de bedrijfsbeoordeling zijn deze gegevens weinig relevant.

"Once a momentum, say a salary expense momentum, is recognized in momentum accounting, monthly salary payments are in fact "nonevents" from the standpoint of performance evaluation" (Ijiri, 1989:45).

Ook wanneer bijvoorbeeld dure leningen worden geconverteerd in goedkopere leningen of wanneer de klanttevredenheid substantieel afneemt, muteert de winstcapaciteit van het eigen vermogen. De kwantificering van dergelijke effecten is vaak een probleem maar via bijvoorbeeld sensitiviteitsstudies kunnen betrouwbare uitspraken worden gedaan (zie ook hoofdstuk 7).

In geen geval zijn debet, credit en/of trebit dimensies van enig accountingstelsel. Het is een, vanuit een sterk instrumentale benadering van het boekhouden geboren, misverstand dat dubbel boekhouden betekent dat bedragen in een debet- en creditkolom worden geplaatst, of anders gezegd dat bij elke transactie ten minste twee grootboekrekeningen muteren $^{17}$. Een stelsel van dubbel boekhouden kan echter goed in één enkele kolom

\footnotetext{
${ }^{17}$ In de accountingliteratuur komen we veel van dergelijke suggesties tegen. "The system of debits and credits illustrated here is the standard double-entry system, so-called because at least two entries, a debit and a credit, are made for each transaction" (Walgenbach, Dittrich en Hanson, 1984:46.). " ... the rules of a double-entry system, so named because at least two accounts are always affected by each transaction" (Horngren en Sundem, 1990:83). Zelfs Ijiri maakt zich schuldig aan het instandhouden van dit misverstand: "The third dimension must be logically deducible from the existing two dimensions (the debit and the credit) of double-entry bookkeeping" (1982:ix).
} 
worden gevoerd, bijvoorbeeld door te werken met negatieve getallen. De vormgeving van enig stelsel is derhalve volstrekt secundair aan zijn conceptuele kader!

Hierna volgt het 'accounting measurement'-model, aangevuld met de belangrijke vraag van de dimensie waarnaar zal worden geadministreerd.

Tabel 5.5 Accounting measurement en triple-entry en momentum accounting.

\begin{tabular}{|l|l|}
\hline \multicolumn{2}{|c|}{$\begin{array}{l}\text { ACCOUNTING MEASUREMENT en } \\
\text { TRIPLE-ENTRY en MOMENTUM ACCOUNTING }\end{array}$} \\
\hline 1.wie? & entity concept \\
\hline 2.wanneer? & recognition \\
\hline 3.waartegen? & money measurement \\
\hline 4.waarop? & classificatie naar item \\
\hline 5.waarnaar? & de dimensie der items \\
\hline
\end{tabular}

\subsection{Samenvatting}

In het algemeen wordt bij het ontwerp van een informatiesysteem een aantal fasen onderscheiden (van ontwerp tot implementatie; zie bijvoorbeeld Hodge en Clements, 1986:175-365). Ten behoeve van het ontwerp van een (strategisch) accounting informatiesysteem onderscheiden Gordon, Larcker en Tuggle (1978) een viertal fasen:

1. Het vaststellen van de gegevensverwerker.

2. Het vaststellen van de systeemgebruiker.

3. Het bepalen van de voor de gegevensverwerking benodigde technologie.

4. Het specificeren van de gegevenskarakteristieken:

a) de gegevens-items (waarover gegevens dienen te worden verstrekt);

b) het formaat waarin de gegevens dienen te worden verstrekt;

c) de vorm van de gegevens (financieel/niét-financieel)

d) de focus van de gegevens (globaal/specifiek)

e) de oriëntatie van de gegevens (intern/extem)

f) de tijdhorizon ((ex post/ex ante)

g) de frequentie van de rapportage.

Helaas ontbreekt ook in het stappenmodel van Gordon et al de vraag naar de van de accounting-items te administreren dimensies. Het is alsof men het principe van het dubbel of tweevoudig boekhouden in de tijd als een axioma is gaan behandelen. Het is deze vraag naar de van de accounting-items te administreren dimensies die ons brengt bij triple-entry en momentum accounting. 
De ontwikkeling van een accounting informatiesysteem dient te zijn ingebed in een informatieplan waarin de ondernemingsleiding zijn visie geeft op de ontwikkeling van de totale informatievoorziening binnen het bedrijf. Dit is het informatiebeleid. Dit beleid is een concrete uiteenzetting van de doeleinden die ten aanzien van de informatievoorziening zullen worden nagestreefd. In het informatiebeleid komen zaken aan de orde als het opzetten van integrale systemen, het realiseren van eenmalige gegevensinvoer (centrale databank), de afstemming op het algemene beleid casu quo kritieke succesfactoren, de afstemming op de organisatiestructuur en de gewenste flexibiliteit voor gegevensmanipulaties. Ook het formuleren van de voor de onderneming relevante bedrijfseconomische criteria is een onderdeel van dit informatiebeleid. Hiermee wordt er voor zorg gedragen dat door de hele informatievoorziening heen de zelfde beoordelingsnormen bestaan. Het spreekt voor zich dat het te ontwikkelen accountingsysteem hierop moet aansluiten. 


\section{Gegevensperceptie en financiële functie}

\subsection{Inleiding}

Nu de kwaliteit van de intern financieel-administratieve dienstverlening ter discussie staat (zie hoofdstuk 4), wordt de behoefte aan een conceptual framework voor de management accounting steeds sterker. Een conceptual framework kan worden gezien als de verzameling van algemeen aanvaarde uitgangspunten voor de beoefening van een vak of tak van wetenschap. Een conceptual framework, zijnde een beschrijving van een doel-middelen relatie, kan de theorievorming stimuleren en kan als referentie dienst doen bij het opsporen van problemen in de huidige in gebruik zijnde systemen. In de financial accounting heeft men inmiddels zo'n conceptual framework ontwikkeld. Doeleinden, te verstrekken overzichten, kwalitatieve gegevens-eisen en te volgen postulaten en principes zijn in dit conceptual framework vastgelegd.

Ook Anthony (1991) signaleert het gebrek aan een (bevredigend) conceptual framework voor de management accounting.

"We don't have the accounting concepts we need" (1991:11).

Anthony vergelijkt de behoefte van een conceptual framework met de behoefte van een land aan een grondwet als basis voor de ontwikkeling van wetten en jurisprudentie (alhoewel het conceptual framework niet de juridische status van grondwet bezit).In hoofdstuk 1 is de vraag aan de orde gesteld in hoeverre management accounting zinvol kan gebruik maken van het voor de financial accounting ontwikkelde conceptual framework voor wat betreft de hierin onderscheiden kwalitatieve gegevenseisen (gegevenskenmerken). De hierbij aangehouden hypothese is:

Het 'conceptual framework' voor de financial accounting is voor wat betreft de hierin onderscheiden gegevenskenmerken tevens bruikbaar voor de management accounting, met dien verstande dat in de management accounting ten aanzien van deze gegevenskenmerken significant andere belangrijkheidscoëficiënten gelden.

Voor de validatie van deze hypothese is in april 1992 een schriftelijke enquête uitgevoerd onder 240 registeraccountants alsmede bij 120 (register)controllers. In dit hoofdstuk worden de resultaten van deze enquête samengevat. De integrale tekst van het enquêteformulier is achter in het boek als bijlage bij dit hoofdstuk opgenomen. 


\subsection{Populaties, steekproef, response en statistische verwerking van de gegevens}

In totaal zijn 240 enquêtes verzonden aan bij het NIvRA ingeschreven accountants (zo'n $3 \%$ van het totaal) en 120 enquêtes aan (register)controllers (dit aantal was het totale aantal afgestudeerde controllers per dat moment) ${ }^{1}$. Voor het aanschrijven van de registeraccountants werd gebruik gemaakt van de NIvRA-gids 1990. Van elke vierde pagina in deze gids werd de eerste controlerend accountant geselecteerd (werkzaam in de financial accounting) en de eerste accountant werkzaam in een controllersfunctie (functie in de management accounting). Om zoveel mogelijk een randomselectie te bewerkstelligen werd van elke tweede vierde pagina van onder naar boven geselecteerd.

Op het totaal van 360 verzonden formulieren bedroeg de response 137 . Dit is $38 \%$. Hiervan was de voor een aantal vragen maximaal bruikbare response 93, zijnde bijna $26 \%$. Een aantal formulieren werd oningevuld geretourneerd, onder andere vanwege beroepsbeëindiging. Op sommige formulieren was een vraag onbeantwoord zodat het aantal respondenten per vraag verschilt ${ }^{2}$.

Eind mei 1992 is een herinnering verstuurd. Deze reminder deed de bruikbare response in absolute zin met ruim $8 \%$ toenemen. Er is nagegaan of deze response afweek van de in een eerder stadium ontvangen response. Dit bleek niet het geval te zijn.

Bij de beoordeling van het mogelijke gebruik van het financial accounting conceptual framework - voor zover dit de gegevenskenmerken betreft - in de management accounting, zijn met name de vragen 10 en 11 van het enquêteformulier van belang. De in deze vragen opgenomen gegevenskarakteristieken zijn ontleend aan het FASB conceptual framework. Voor de beantwoording van beide vragen is een 5-punts Likertschaal opgesteld, aflopend van bijzonder belangrijk tot volstrekt onbelangrijk. In dit verband is gekozen voor een nonparametrische testing ('ranking test' of 'distribution-free test'). De non-parametrische statistiek is bij uitstek geschikt voor onderzoek in de gedragswetenschappen (Siegel en Castellan, 1988:xv). Ten aanzien van centrale tendenties van verzamelingen dient in dit verband eerder te worden gedacht aan de mediaan als maatstaf dan aan het gemiddelde. Maar vanwege de grote bekendheid van het gemiddelde als indicator van centrale tendentie zal over deze maatstaf worden gerapporteerd.

Ten aanzien van de hypothese zoals die hiervoor is geformuleerd, is er sprake van twee onafhankelijke steekproeven: uit de registeraccountants=RA's respectievelijk registercon-

1 Deze enquête-formulieren werden in het tijdschrift 'Controllersvizier' (losbladig) opgenomen. De redactie van Controllersvizier ben ik bijzonder erkentelijk voor haar vrijwillige medewerking in dezen.

${ }^{2}$ Dit geldt met name ten aanzien van de vragen 5 en 6 van het enquêteformulier. 
trollers=RC's. Voor de RA's kan een groep van financial accountingfunctionarissen en een groep voor management accountingfunctionarissen worden onderscheiden waarbij elke groep afzonderlijk met de groep van RC's kan worden vergeleken. Ten einde de verschillen in de antwoorden per groep te kunnen beoordelen, is gelet op de aard der gegevens de non-parametrische two-sample Kolmogorov-Smirnov test uitgevoerd. De nulhypothese die hierbij steeds is aangehouden, is dat de antwoorden (waarderingen) van de onderscheiden groepen de zelfde verdeling (cumulatieve opbouw) kennen. Als significantienorm is steeds $5 \%$ aangehouden bij een betrouwbaarheidsinterval van $95 \%$.

\subsection{Enquêteresultaten; profielschets van de respondenten: accountants en controllers}

Het totaal der respondenten kan wat opleiding betreft als volgt worden gecategoriseerd (zie tabel 6.1):

Tabel 6.1 Profielschets respondenten.

\begin{tabular}{|l|l|c|}
\hline groep & opleiding & aantal \\
\hline$A_{1}$ & NIvRA-accountant & 58 \\
\hline$A_{2}$ & $\begin{array}{l}\text { Postdoctoraal- } \\
\text { accountant }\end{array}$ & 31 \\
\hline $\mathrm{C}$ & Controllers & 41 \\
\hline & Totaal & 130 \\
\hline
\end{tabular}

Hierbij zijn 2 respondenten in groep $A_{2}$ opgenomen die ook in groep $C$ hadden kunnen worden ingedeeld (registeraccountants tevens registercontrollers). Waar nodig in verband met de zuiverheid van de analyses, zijn de antwoorden van deze respondenten buiten beschouwing gelaten.

De enquêteresultaten bevestigen dat accountants veel meer werkzaam zijn op het gebied van de externe berichtgeving dan controllers die meer op het gebied van de interne berichtgeving hun emplooi vinden (zie vraag 5 ). Op de schaal van 1-5 van volledig financial accounting naar volledig management accounting bedroeg de cumulatieve relatieve frequentie bij de RA's in de eerste drie schaaleenheden $68 \%$ terwijl dit voor de RC's slechts $19 \%$ bedroeg. De postdoctorale accountants neigen in dit verband iets meer naar management accounting dan hun NIvRA-collegae (75\% respectievelijk $65 \%$ cumulatieve frequentie in de eerste drie schaaleenheden). Dit beeld wordt min of meer bevestigd in de gemiddelde verdeling qua tijd van de huidige werkzaamheden. Deze verdeling is als volgt (zie tabel 6.2; uitkomsten afgerond op hele procenten): 
Tabel 6.2 Overzicht tijdsbesteding.

\begin{tabular}{|l|c|c|c|c|}
\hline groep & \multicolumn{2}{|l|}{$\begin{array}{l}\text { aantal } \\
\text { respondenten }\end{array}$} & \multicolumn{2}{|l|}{$\begin{array}{l}\text { gemiddelde huidige } \\
\text { procentuele tijdsbesteding }\end{array}$} \\
\hline & & controle & advies & management \\
\hline $\mathrm{A}_{1}$ & 58 & 37 & 37 & 26 \\
\hline $\mathrm{A}_{2}$ & 30 & 21 & 50 & 30 \\
\hline $\mathrm{C}$ & 41 & 14 & 62 & 24 \\
\hline & Totaal 129 & & & \\
\hline
\end{tabular}

In de tijd is waarneembaar dat het controle-werk voor accountants dalende is (vraag $2 \mathrm{~b}$ ). Maakten de controlewerkzaamheden voor de groepen $A_{1}$ en $A_{2}$ drie jaar geleden nog gemiddeld $42 \%$ van het totale werk uit (bij 35\% advieswerk), tegenwoordig is dit nog gemiddeld slechts $32 \%$ (bij $42 \%$ advieswerk) ${ }^{3}$. Deze ontwikkeling is voor beide groepen nagenoeg gelijk. Vanwege het nog jonge bestaan van het 'zelfstandige' controllersberoep kan over de ontwikkeling in de tijd van de werkzaamheden binnen deze groep geen uitspraak worden gedaan.

Ten aanzien van de functie-inhoud bedroeg de cumulatieve frequentie voor de categorieën $4+5$ van de Likertschaal (management accounting) voor groep $\mathrm{A}_{1} 35 \%$ (voor groep $\mathrm{A}_{2}$ was dit $25 \%$ en voor groep C $82 \%$ ). Deze cijfers geven aan dat een substantieel deel van de werkzaamheden van een accountant ligt op het terrein van de interne berichtgeving. In tabel 6.3 zijn de gegevens over de functie-inhoud samengevat.

Tabel 6.3 Overzicht functie-inhoud.

\begin{tabular}{|l|c|c|c|c|c|c|}
\hline groep & $\begin{array}{l}\text { aantal } \\
\text { respondenten }\end{array}$ & \multicolumn{3}{l|}{$\begin{array}{l}\text { cumulatieve relatieve } \\
\text { frequentie } \\
\text { volledig FA } \\
1\end{array}$} & \multicolumn{4}{c|}{$\begin{array}{l}\text { volledig MA } \\
\text { val }\end{array}$} \\
\hline $\mathrm{A}_{1}$ & 34 & 18 & 34 & 65 & 94 & 100 \\
\hline $\mathrm{A}_{2}$ & 20 & 0 & 50 & 75 & 85 & 100 \\
\hline $\mathrm{C}$ & 39 & 3 & 6 & 19 & 70 & 100 \\
\hline & Totaal 93 & & & & & \\
\hline
\end{tabular}

\footnotetext{
${ }^{3}$ Bij de interpretatie van deze gegevens dient te worden bedacht dat het soms onduidelijk kan zijn onder welke categorie van werkzamheden bepaalde activiteiten vallen. Waartoe bijvoorbeeld is door de respondenten de advisering omtrent interne controleprocedures gerekend? Overigens bedroeg in 1988 het controle-aandeel in de totale omzet bij de grote Nederlandse accountantskantoren nog zo'n 65\% (Het Financieele Dagblad, mei 1989). Het feit dat dit aandeel dalende is (zie ook Meuwissen, 1992:15-17) wordt door de enquêteresultaten bevestigd.
} 
Het overgrote deel van de respondent-accountants was werkzaarn op een accountantskantoor $(45 \%)$ respectievelijk in het (overige) bedrijfsleven (40\%) (zie vraag $4 \mathrm{~A}$ ). Van de respondent-controllers was $83 \%$ werkzaam in het (overige) bedrijfsleven. Het restant was voor beide groepen gelijk verdeeld tussen non-profit sector en overheid. Van de respondenten uit groep $A_{1}$ waren meer personen werkzaam op accountantskantoren dan van de respondenten uit groep $\mathrm{A}_{2}$ (50\% respectievelijk 37\%). In tabel 6.4 is een overzicht gegeven van de sector waarin de respondenten werkzaam waren.

Tabel 6.4 Overzicht werkkring.

\begin{tabular}{|l|c|c|c|c|c|}
\hline groep & $\begin{array}{l}\text { aantal } \\
\text { resp. }\end{array}$ & \multicolumn{2}{l}{ bedrijfssector } \\
\hline & & acc. kantoor & bedrijfsleven & non-profit & overheíd \\
\hline $\mathrm{A}_{1}$ & 58 & 29 & 20 & 5 & 4 \\
\hline $\mathrm{A}_{2}$ & 30 & 11 & 15 & 2 & 2 \\
\hline Subtotaal & 88 & 40 & 35 & 7 & 6 \\
\hline C & 40 & 1 & 33 & 3 & 3 \\
\hline Totaal & 128 & 41 & 68 & 10 & 9 \\
\hline
\end{tabular}

In tabel 6.5 is weergegeven wat de functie-inhoud van de respondenten (hoofdzakelijk) bedroeg (zie vraag 5). De gegevens bevestigen het beeld dat accountants meer op het gebied van de financial accounting werkzaam zijn dan controllers.

Tabel 6.5 Overzicht van de functie-inhoud van de respondenten.

\begin{tabular}{|c|c|c|c|}
\hline & $\begin{array}{l}\text { financial } \\
\text { accounting }\end{array}$ & $\begin{array}{l}\text { management } \\
\text { accounting }\end{array}$ & $\begin{array}{l}\text { middenpositie en } \\
\text { niet van toepas- } \\
\text { sing }\end{array}$ \\
\hline Accountants 60 & 25 & 17 & 18 \\
\hline Controllers 41 & 2 & 32 & 7 \\
\hline Totaal & 27 & 49 & 25 \\
\hline
\end{tabular}

Als belangrijkste functie van management accounting (vraag 6) kwam naar voor het ondersteunen van beslissingsprocessen (planning). In totaal gaf $35 \%$ van de respondenten deze functie de hoogste prioriteit. Dit betekent dat in de management accounting aan het aspect 'relevantie' meer gewicht zou moeten worden toegekend dan aan het aspect 'betrouwbaarheid' (zie ook tabel 2 in hoofdstuk 5). Voorts gaf 10\% respectievelijk 18\% van de respondenten aan dat gegevens voor de ondersteuning en beheersing respectievelijk voor de ondersteuning en beheersing en interne verantwoording door de 
management accounting dienen te worden verstrekt. In geval van een nationaal georienteerd bedrijf (vraag 4B) wordt de verantwoordingsfunctie van management accounting aanzienlijk belangrijker ingeschat dan in geval van een internationaal georiënteerd bedrijf waarin de component 'beheersing' ('control') relatief belangrijker wordt gevonden. Respondenten die aangaven meer in het vlak van de financial accounting werkzaam te zijn, waardeerden de component 'verantwoording' substantieel hoger dan hun collegae (driekwart van de respondenten die bij vraag 5 de categorieën $1+2$ van de Likertschaal hadden aangekruist, vonden de verantwoordingsfunctie van accounting primair).

\subsection{Hypothese-testing}

De in de inleiding van dit hoofdstuk vervatte hypothese valt feitelijk uiteen in een tweetal vraagstukken:

1) Is het conceptual framework zoals ontwikkeld voor de financial accounting en voor zover dit de gegevenskenmerken betreft, ook bruikbaar voor de management accounting?

2) In hoeverre worden in de management accounting aan de onderscheiden gegevenskenmerken andere belangrijkheids-coëfficiënten toegekend dan in de financial accounting?

Antwoord op de eerste vraag kan worden verkregen door na te gaan in hoeverre er bij specialisten in de management accounting behoefte bestaat gegevenskenmerken toe te voegen aan het raamwerk van gegevenskenmerken zoals dat bestaat in de financial accounting. Om deze behoefte te inventariseren strekte vraag 11 van het enquêteformulier.

Noch van de 25 registeraccountants die een financial accountingfunctie vervulden (categorie 1 en 2 van vraag 5), noch van de 10 registeraccountants die een soort tussenpositie innamen in financial accounting en management accounting (categorie 3 van vraag 5) gaf enig respondent aan een gegevenskenmerk te willen toevoegen.

Van de 18 registeraccountants met een management accountingfunctie (categorie $4+5$ van vraag 5) gaf slechts één respondent te kennen gegevenskenmerken te willen toevoegen ('relevantie' en 'begrijpbaarheid'). Van de 33 controllers in een management accountingfunctie gaven 5 respondenten aan een gegevenskenmerk te willen aanvullen: verantwoording afleggen, efficiency, informatiewaarde, begrijpelijkheid en strategische aspecten. Van de 5 controllers die een middenpositie innamen gaf niemand aan behoefte te hebben de vermelde gegevenskenmerken uit te breiden. Bij de 4 controllers met een hoofdzakelijk financial accounting getinte functie gaf één controller aan het aspect 'volledigheid' te willen toevoegen. Uit deze inventarisatie kan voorzichtig worden geconcludeerd dat het financial accounting raamwerk van gegevenskenmerken zoals 
voorgesteld door onder andere de FASB, ook goede diensten zal kunnen bewijzen in de management accounting (zie ook de nadere uitwerking hierop in met name tabel 6.11). Dit geldt te meer omdat een aantal van de genoemde aanvullende gegevenskenmerken (zoals efficiency, begrijpelijkheid en informatiewaarde) wordt afgedekt in de algemene gegevens-karakteristieken en voorwaarden zoals die in het FASB-model zijn genoemd (met name 'benefits > costs' en 'understandability (als bepalend voor 'decision usefullness'). Bovendien is het aspect 'volledigheid' een onderdeel van het in het raamwerk als 'representational faithfulness' aangeduide kenmerk.

Voor het testen van de in het begin van dit hoofdstuk vermelde hypothese is nagegaan of in de management accounting de onderscheiden gegevenskenmerken anders worden gewogen dan in de financial accounting. Hiertoe zijn de antwoorden op de vragen 10 en 11 geanalyseerd. Hierbij dient te worden bedacht dat de in vraag 11 onderscheiden gegevenskenmerken deelaspecten zijn van de in vraag 10 genoemde hoofdkenmerken, relevantie en betrouwbaarheid. Hierdoor is het mogelijk de mate van interne consistentie te meten in de beantwoording van vraag 10 en 11 .

In tabel 6.6 en 6.7 zijn de absolute scores op vraag 10 respectievelijk vraag 11 samengevat.

Tabel 6.6 Absolute score op relevantie en betrouwbaarheid.

\begin{tabular}{|c|c|c|c|c|c|}
\hline \multicolumn{3}{|c|}{ bijzonder belangrijk } & \multicolumn{3}{|c|}{ volstrekt onbelangrijk } \\
\hline $\begin{array}{l}\text { waardering } \\
1\end{array}$ & 2 & 3 & 4 & 5 & TOTAAL \\
\hline \multicolumn{6}{|l|}{ Relevantie } \\
\hline 71 & 44 & 8 & 2 & 1 & 126 \\
\hline \multicolumn{6}{|c|}{ Betrouwbaarheid } \\
\hline 56 & 54 & 13 & 3 & 1 & 127 \\
\hline
\end{tabular}


Tabel 6.7 Absolute score op deelaspecten.

\begin{tabular}{|c|c|c|c|c|c|}
\hline \multicolumn{3}{|c|}{ bijzonder belangrijk } & \multicolumn{3}{|c|}{ volstrekt onbelangrijk } \\
\hline $\begin{array}{c}\text { waardering } \\
1\end{array}$ & 2 & 3 & 4 & 5 & TOTAAL \\
\hline \multicolumn{6}{|c|}{ Predictive value } \\
\hline 26 & 60 & 26 & 14 & 1 & 127 \\
\hline \multicolumn{6}{|c|}{ Feed-back value } \\
\hline 41 & 65 & 17 & 3 & 1 & 127 \\
\hline \multicolumn{6}{|l|}{ Timeliness } \\
\hline 51 & 55 & 18 & 3 & 0 & 127 \\
\hline \multicolumn{6}{|l|}{ Neutrality } \\
\hline 29 & 39 & 50 & 8 & 1 & 127 \\
\hline \multicolumn{6}{|c|}{ Comparability/Consistency } \\
\hline 29 & 71 & 22 & 3 & 0 & 125 \\
\hline \multicolumn{6}{|l|}{ Verifiability } \\
\hline 26 & 65 & 27 & 9 & 0 & 127 \\
\hline \multicolumn{6}{|c|}{ Representational faithfulness } \\
\hline 12 & 51 & 44 & 15 & 1 & 123 \\
\hline
\end{tabular}

Voor het vergelijken van de mate waarin men in het algemeen relevantie casu quo betrouwbaarheid van belang acht, is voor de totale steekproefpopulatie een gemiddelde score berekend voor beide gegevenskenmerken. Hierbij is een antwoord in categorie 1 op de vijfpunts-relevantieschaal met 5 punten gewaardeerd, een antwoord in categorie 2 is gewaardeerd met 4 punten, enzovoort. Voor het aspect betrouwbaarheid is op soortgelijke wijze een gemiddelde score bepaald. Langs deze weg kan op basis van de enquêteresultaten het volgende worden vastgesteld (zie tabel 6.8 ):

Tabel 6.8 Relevantie versus betrouwbaarheid (aantal respondenten 127).

\begin{tabular}{|l|c|}
\hline aspect & gemiddelde score \\
\hline relevantie & 4,44 \\
\hline betrouwbaarheid & 4,27 \\
\hline $\begin{array}{l}\text { ratio relevantie/ } \\
\text { betrouwbaarheid }\end{array}$ & 1,04 \\
\hline
\end{tabular}


De gemiddelde ratio 'relevantie/betrouwbaarheid' ligt hierbij derhalve op 4,44/4,27= 1,04. Interessant is het antwoord op de vraag of deze ratio anders ligt per bedrijfssector, per bedrijfsoriëntatie, per opleiding, duur van het dienstverband en - hetgeen centraal staat in dit onderzoek - per functie-inhoud (financial accounting versus management accounting).

In de in deze enquête onderscheiden bedrijfssectoren is de bedoelde ratio gemiddeld als volgt (zie tabel 6.9):

Tabel 6.9 Relevantie versus betrouwbaarheid en de werkkring der respondenten.

\begin{tabular}{|l|l|l|l|l|}
\hline bedrijfssector & $\begin{array}{l}\text { acc. } \\
\text { kantoor }\end{array}$ & bedrijfsieven & $\begin{array}{l}\text { non. } \\
\text { profit }\end{array}$ & overheid \\
\hline $\begin{array}{l}\text { relevantie/ } \\
\text { betrouwbaarheid }\end{array}$ & 0,99 & 1,05 & 1,16 & 1,08 \\
\hline aantal respond. & 40 & 67 & 9 & 9 \\
\hline
\end{tabular}

Alhoewel de non-profit sector een opvallend hoge ratio geeft, is deze uitkomst niet dusdanig dat van een significant verschil kan worden gesproken.

In het internationaal georiënteerd bedrijf (dat wil zeggen, meer dan de helft van de omzet wordt in het buitenland gerealiseerd) ligt de verhouding 'relevantie/betrouwbaarheid' op 1,07 , voor het nationaal georiënteerd bedrijf is deze verhouding 1,03 . Geen grote verschillen derhalve in vergelijking met de gemiddelde steekproefscore. Voor wat betreft de relatie van de genoemde ratio en de duur van het functieverband (zie vraag 3 ) geldt dat naarmate het functieverband langer heeft geduurd, de ratio oploopt (doch niet significant): van 1,00 tot 1,05 tot 1,07 .

Wanneer men de groepen $A_{1}$ en $A_{2}$ samen neemt ligt de verhouding relevantie/betrouwbaarheid op 1,15, terwijl deze in groep $C$ op 1,00 ligt. Gezien de management accountingfunctie van controllers zou men een andere verhouding mogen verwachten. Wanneer men evenwel de relatieve frequentieopbouw meeneemt, ontstaat een iets ander en daarmee meer in de lijn van de verwachtingen liggend beeld. In de categorieën $1+2$ voor relevantie antwoordt $88 \%$ van alle (86) ondervraagde accountants terwijl in deze categorieën $98 \%$ van de controllers antwoordt. Voor het aspect betrouwbaarheid ligt dit op respectievelijk $92 \%$ en $74 \%$. Hiermee wordt de vermoede voorkeur van accountants voor betrouwbaarheid boven relevantie bevestigd. Bij controllers ligt dit omgekeerd. De ten opzichte van de controllers relatief hoge ratio 'relevantie/betrouwbaarheid' bij accountants kan met name worden verklaard uit het feit dat vele accountants een management accountingfunctie en dus een met een controller vergelijkbare functie vervullen. De invloed van met name deze factor wordt hierna nader geanalyseerd. 
De achtergrond van de accountant (al dan niet universitair) speelt geen rol van betekenis in de perceptie relevantie-betrouwbaarheid (de betreffende ratio was in deze gevallen respectievelijk 1,03 en 1,00 ).

Voor wat betreft de relatie tussen de aard van de accountingfunctie en de mate waarin het aspect relevantie respectievelijk betrouwbaarheid belangrijk wordt geacht, zijn de tabellen $6.10,6.11$ en 6.12 samengesteld.

Van alle respondenten die een management accountingfunctie vervullen (hiertoe zijn beschouwd alle respondenten die bij vraag 5 de categorieën 4 en 5 hebben aangekruist) bedraagt de ratio 'relevantie/betrouwbaarheid' 1,11 . Bij de respondenten die een financial accountingfunctie vervullen ligt deze ratio op 0,97 . Derhalve is de omvang van de ratio in belangrijke mate afhankelijk van de inhoud van de accountingfunctie. Wanneer men voor beide functies en gegevenscriteria uitsluitend de categorieën 1 en 2 in de schaal van bijzonder belangrijk naar volstrekt onbelangrijk in ogenschouw neemt (ten einde eventuele misinterpretaties uit te schakelen), wordt dit beeld verder versterkt. De ratio relevantie/betrouwbaarheid ligt in dit geval bij de management accountants op 1,28 en bij de financial accountants op 0,94 .

Tabel 6.10 De relatie tussen het aspect relevantie en de inhoud van de accountingfunctie.

\begin{tabular}{|c|c|c|c|c|c|c|}
\hline \multicolumn{7}{|c|}{ RELEVANTIE (frequenties) } \\
\hline & & \multicolumn{5}{|c|}{ wolledig FA $\longleftrightarrow$ wolledig MA } \\
\hline & & 1 & 2 & 3 & 4 & 5 \\
\hline \multirow{4}{*}{ bijzonder belangrijk } & (1) & 4 & 7 & 13 & 22 & 9 \\
\hline & (2) & 3 & 9 & 5 & 8 & 6 \\
\hline & (3) & 0 & 2 & 0 & 0 & 1 \\
\hline & (4) & 0 & 2 & 0 & 0 & 0 \\
\hline \multicolumn{2}{|c|}{ volstrekt onbelangrijk } & 0 & 0 & 0 & 1 & 0 \\
\hline & Totaal 92 & 7 & 20 & 18 & 31 & 16 \\
\hline
\end{tabular}


Tabel 6.11 De relatie tussen het aspect betrouwbaarheid en de inhoud van de accountingfunctie.

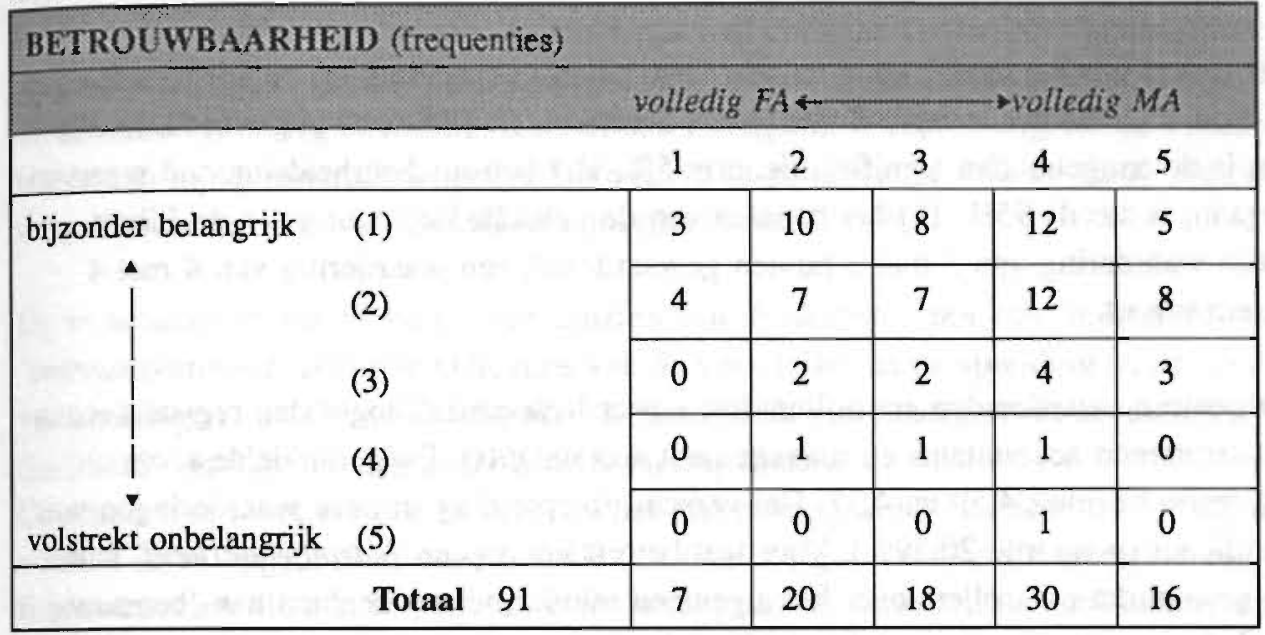

Tabel 6.12 Relatieve frequentie van de score relevantie/betrouwbaarheid in relatie tot de inhoud van de accountingfunctie.

\section{RELEYANTIE/BETROUWBAARHEID) (relatieve frequentie) \\ volledig $F A \leftrightarrow$ volledig $M A$ \\ $(1+2)$ \\ $(1+2)$}

bijzonder belangrijk

$(1+2)$

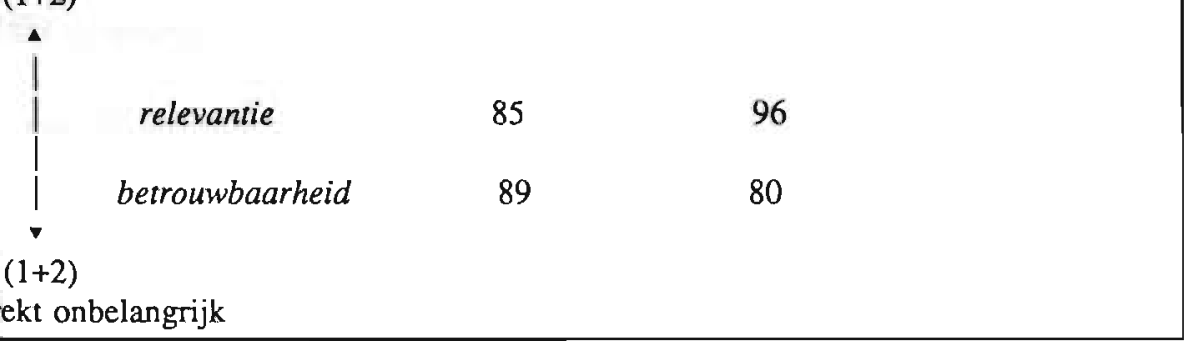

Ook in de opbouw van de verdeling rond het gemiddelde is een voorkeur waarneembaar van management accountants/controllers voor relevantie boven betrouwbaarheid. Maar gezien de prospectieve inhoud van de taken en functies van de management accountant/controller ten opzichte van de (controlerend) accountant (zie Bromwich, 1988:26; Wallage en Tijhuis, 1992:8) zou men bij controllers een grotere tolerantie ten aanzien van de betrouwbaarheid van de gegevens verwachten en een dito hogere ratio relevantie/betrouwbaarheid ${ }^{4}$.

\footnotetext{
4 Wellicht dat controllers nog in (te) sterk door accountantsculturen bepaalde omgevingen worden opgeleid.
} 


\subsubsection{Statistische beoordeling}

Voor het testen van de significantie van de verschillen in spreiding op de antwoorden van vraag 10 en 11 is de two-sample Kolmogorov-Smirnov test (KS-test) uitgevoerd. In alle gevallen is de aangehouden significantienorm $5 \%$. Het betrouwbaarheidsinterval waarvan is uitgegaan, is steeds $95 \%$. Bij het bepalen van de gemiddelde score is op de Likertschaal een waardering van 5 met 5 punten gewaardeerd, een waardering van 4 met 4 punten, enzovoort.

In het algemeen waardeerden controllers het aspect 'relevantie' hoger dan registeraccountants (controlerend accountants en management accountants). De gemiddelde score bedroeg respectievelijk 4,59 en 4,37. Het verschil in spreiding in deze waarderingen was niét significant ( $\mathrm{p}$-waarde 20,29\%). Voor wat betreft het aspect 'betrouwbaarheid' kan worden gesteld dat controllers over het algemeen minder belang hechten aan 'betrouwbaarheid' dan registeraccountants (controlerend accountants en management accountants). Bij een gemiddelde score van respectievelijk 3,54 en 4,39 is het geconstateerde verschil in spreiding evenmin significant (p-waarde $17,47 \%$ ).

Wanneer de functie-inhoud expliciet in de analyse wordt meegenomen, kan worden gesteld dat er een belangrijk verschil bestaat tussen de waardering van financial accountants ten opzichte van management accountants (inclusief controllers) voor wat betreft het aspect 'relevantie'. Financial accountants waarderen dit aspect gemiddeld op 4,19, terwijl de gemiddelde score bij management accountants 4,57 bedraagt. Het verschil in spreiding is niét significant ( $\mathrm{p}$-waarde $14,82 \%$ ).

De beoordeling van het aspect 'betrouwbaarheid' door de hiervoor genoemde twee groepen bleek niét significant afhankelijk te zijn van de functie-inhoud (gemiddelde scores respectievelijk 4,33 en 4,11) en ook de spreiding rond deze waarden bij beide groepen bleek niét significant te verschillen (p-waarde $31 \%$ ).

Registeraccountants in een management accountingfunctie bleken het aspect 'relevantie' hoger te waarderen dan registeraccountants in een financial accountingfunctie (gemiddelde score respectievelijk 4,53 en 4,15). Wat de spreiding in de waarderingen betreft waren de verschillen niét significant ( $p$-waarde $27,47 \%$ ). Registeraccountants in een management accountingfunctie waardeerden het aspect 'betrouwbaarheid' beperkt hoger dan registeraccountants in een financial accountingfunctie (gemiddelde score respectievelijk 4,41 en 4,35; p-waarde $42,29 \%)^{5}$.

\footnotetext{
${ }^{5}$ Alhoewel dit een opvallende uitkomst is, kan hieraan (gezien de p-waarde) geen definitieve conclusie worden vertonden.
} 
Ten aanzien van het aspect 'relevantie' oordeelden registeraccountants in een management accountingfunctie vrijwel het zelfde als hun collegae-controllers (gemiddelde score respectievelijk 4,53 en 4,54; p-waarde 37,99\%). Wat het aspect 'betrouwbaarheid' betreft, dit scoorde bij de registeraccountants in een management accountingfunctie aanzienlijk hoger dan bij de controllers (gemiddelde score respectievelijk 4,41 en 3,90). Het verschil in spreiding was evenwel niét significant (p-waarde 27,64\%).

De verschillen in waarderingen ten aanzien van de deelaspecten van 'relevantie' en 'betrouwbaarheid' alsmede indicaties van de verschillen in de spreiding in de scoreverzamelingen van financial accountants ten opzicht van management accountants (inclusief controllers), zijn in tabel 6.13 samengebracht.

Concluderend moet worden gesteld dat het aspect 'relevantie' alsmede de deelaspecten waaruit dit is opgebouwd, onvoldoende (dit is niét-significant) in de perceptie van de functionarissen die een management accountingfunctie vervullen tot uitdrukking komen. Het is waarschijnlijk dat registeraccountants die een management accountingfunctie vervullen zich maar moeilijk kunnen losmaken van de in hun opleiding zo benadrukte aspecten als 'betrouwbaarheid', 'neutraliteit' en 'controleerbaarheid'. In een management accountingfunctie die feitelijk prospectief is gericht, zal de accountant bereid moeten zijn op deze criteria in te leveren ten gunste van de relevantie. Maar ook controllers kiezen niet eenduidig voor relevantie. Deels zou dit kunnen worden verklaard uit het feit dat de opleiders van controllers voor een niet onbelangrijk deel zelf accountant zijn casu quo dat de opleiding voor controllers nog te sterk op het werk van de controlerend accountant is gericht ${ }^{6}$.

\footnotetext{
${ }^{6}$ Mijns inziens dient met name het vak administratieve organisatie in cen management accountants- c.q. controllersperspectief van andere inhoud te worden voorzien (in elk geval qua accenten) dan in een financial accountantsperspectief.
} 
6 Gegevensperceptie en financiële functie

Tabel 6.13 Gemiddelde scores van financial accountants ten opzichte van management accountants (inclusief controllers) op een aantal gegevenscriteria.

\begin{tabular}{|c|c|c|c|}
\hline \multirow[b]{2}{*}{ aspect } & \multicolumn{2}{|c|}{ gemiddelde score } & \multirow[b]{2}{*}{$\begin{array}{l}\text { indicatie van de } \\
\text { significantie van } \\
\text { verschillen in } \\
\text { spreiding } \\
\text { (p-waarde) }\end{array}$} \\
\hline & $\begin{array}{l}\text { financial } \\
\text { accountants }\end{array}$ & $\begin{array}{l}\text { management } \\
\text { accountants } \\
\text { (inclusief control. } \\
\text { lers) }\end{array}$ & \\
\hline $\begin{array}{l}\text { voorspellende } \\
\text { waarde }\end{array}$ & 3,63 & 3,86 & $26,83 \%$ \\
\hline $\begin{array}{l}\text { feedback } \\
\text { waarde }\end{array}$ & 4,27 & 4,04 & $28,90 \%$ \\
\hline tijdigheid & 4,15 & 4,14 & $34,90 \%$ \\
\hline neutraliteit & 3,35 & 3,65 & $36,34 \%$ \\
\hline vergelijkbaarheid & 3,77 & 4,06 & $41,80 \%$ \\
\hline controleerbaarheid & 3,65 & 3,59 & $15,49 \%$ \\
\hline $\begin{array}{l}\text { externe } \\
\text { validiteit }\end{array}$ & 3,19 & 3,21 & $8,02 \%$ \\
\hline
\end{tabular}

Bij vraag 10 en 11 van het enquête-formulier is ten behoeve van het testen van de onderlinge consistentie van de antwoorden bovendien een aantal correlatietests uitgevoerd (over maximaal 125 respondenten). Hierbij is de Spearman rank-order correlatiecoëfficiënt berekend. Zoals in het FASB-model overduidelijk blijkt (zie voor dit model hoofdstuk 5), zijn relevantie en betrouwbaarheid de twee basiskwaliteiten van financiële gegevens. Deze basiskenmerken kunnen verder worden uitgewerkt in een aantal deelkenmerken. Zo wordt bijvoorbeeld het aspect 'relevantie' nader onderverdeeld in de aspecten 'voorspellende waarde', 'tijdigheid' en 'feedback waarde'. Het zou mogen worden verwacht dat wanneer een respondent het aspect 'relevantie' hoog waardeert, deze score kan worden teruggevonden in de waardering van de genoemde deelaspecten (positieve correlatie). In dit verband zijn bij de beoordeling van de significantie van de correlaties eenzijdige tests uitgevoerd.

De correlatie tussen de waarderingen van de aspecten 'relevantie' en 'voorspellende waarde' bleek vrij groot. De significantiegrens (gecorrigeerd voor gelijke rangordes) bedroeg $2,185 \%$, dat wil zeggen, de kans is $2,185 \%$ dat de nulhypothese (de veronderstelling dat er geen associatie bestaat tussen beide aspecten), ten onrechte wordt verworpen. Bij een significantienorm van $5 \%$ is deze correlatie significant.

De correlatie van de waarderingen van de aspecten 'relevantie' en 'feedback- waarde' was opvallend laag (een significantiegrens van $41,125 \%$ ) en bovendien negatief! (Rho en Tau gecorrigeerd voor gelijke rangordes respectievelijk $-0,2$ en $-0,18$ ). Daarentegen was 
de correlatie tussen de waarderingen van de aspecten 'relevantie' en 'tijdigheid' weer groter en positief, maar bij een significantienorm van $5 \%$ niét significant (significantiegrens $7,78 \%$ ). De correlatie tussen de waarderingen van de aspecten 'neutraliteit', 'controleerbaarheid' en 'externe validiteit' met hun moederkenmerk 'betrouwbaarheid' was hoog en positief (een significantiegrens van respectievelijk $1,215 \%, 0,05 \%$ en 0,0 $2 \%$ ). Bij de gehanteerde significantienorm van $1 \%$ zijn deze correlaties alle significant.

Voor de beoordeling van de correlatie tussen de waarderingen van de basisaspecten 'relevantie' en 'betrouwbaarheid' is een tweezijdige test uitgevoerd. Bij een significantiegrens van $27,61 \%$ en een norm van $5 \%$ kan de (negatieve) correlatie tussen beide aspecten niét als zijnde significant worden aangemerkt.

Uit de uitgevoerde correlatietests mag worden geconcludeerd dat de interne consistentie van de beantwoording van het betreffende deel van de enquête hoog is. Alhoewel geen bewijs zijnde, betekent dit toch dat de geloofwaardigheid van de eerder uitgevoerde betrouwbaarheidstests niet is aangetast.

In de inleiding tot dit hoofdstuk is de volgende hypothese gesteld:

Het 'conceptual framework' voor de financial accounting is voor wat betreft de hierin onderscheiden gegevenskenmerken tevens bruikbaar voor de management accounting, met dien verstande dat in de management accounting ten aanzien van deze gegevenskenmerken significant andere belangrijkheidscoëfficiënten gelden.

Op basis van de uitgevoerde non-parametrische tests dient deze hypothese te worden verworpen.

Zoals bij het begin van deze paragraaf is aangegeven, valt de hiervoor gestelde hypothese feitelijk uiteen in twee deelhypothesen:

a) Het conceptual framework zoals ontwikkeld voor de finunciul accounting en voor zover dit de gegevenskenmerken betreft, is tevens bruikbaar voor de management accounting.

b) In de management accounting worden aan de onderscheiden gegevenskinmerken andere belangrijkhcidscoëfficiënten toegekend dan in de financial accounting.

Op basis van de gegevens uit dit onderzoek kan worden gesteld dat het model van gegevenskenmerken uit het conceptual framework van de financial accounting ook volstaat voor de management accounting. Dit betekent validering van deelhypothese $a$. In de management accounting worden bovendien ten aanzien van de in dit model onderscheiden 
gegevenskenmerken géén significant afwijkende belangrijkheidscoëfficiënten gehanteerd. Deelhypothese $b$ dient op basis hiervan te worden verworpen.

\subsection{Overige enquêteresultaten}

Het externe en interne berichtgevingssysteem bleek in de bedrijven waar de respondenten werkzaam zijn slechts in enkele gevallen van elkaar te verschillen (vraag 7A). Derhalve valt grote overeenstemming te constateren tussen externe en interne accountingsystemen. De categorieën 4 en 5 (volledig afwijkend) vertegenwoordigden respectievelijk $12 \%$ en $2 \%$ en derhalve in totaal slechts $14 \%$ van de totale response op de betreffende vijfpuntsschaal. Deze resultaten vormen geen sluitend bewijs voor de bewering dat de praktijk van de management accounting wordt gedreven door een externe verslagleggings-mentaliteit, maar deze resultaten zijn toch een indicatie van de bereidheid interne berichtgevingssystemen op te offeren aan externe systemen (zie Porter et al, 1987:58).

Als belangrijkste redenen voor de gesignaleerde overeenstemming tussen de interne en de externe berichtgevingssystemen werden genoemd (1) efficiency (kosten) en (2) eenvoud (vraag 7B). Hierbij is opvallend dat controllers vaker het aspect 'kosten' noemen dan accountants die meer frequent 'eenvoud' als belangrijkste reden opgeven. De verschillen tussen het externe en interne berichtgevingssysteem concentreren zich met name in het (overige) bedrijfsleven (zie vraag 4A). Bij een meer internationaal georiënteerd bedrijf nemen de verschillen tussen beide berichtgevingssystemen toe. Volstrekte afwijking tussen beide systemen komt uitsluitend bij dit type bedrijven voor (4\% van de onderzochte gevallen).

Wanneer het externe en interne berichtgevingssysteem van elkaar afwijken (vraag 7C), vindt dit met name plaats op het terrein van (1) de waardering van duurzame materiële activa en (2) de winstbepaling. Van de 126 respondenten rapporteert in beide gevallen $17,5 \%$ deze afwijkingen. Ook voorzieningen worden relatief vaak extern anders behandeld dan intern (ruim 14\% van de onderzochte gevallen), duurzame immateriële activa worden vaak afwijkend gewaardeerd (ruim 11\%) terwijl intern in 1 op de 9 bedrijven rekening wordt gehouden met rente over het eigen vermogen (en dus met opportunity kosten). Voor externe doeleinden werd in $14 \%$ van de onderzochte gevallen een andere consolidatieprocedure gevolgd. Opvallend is de frequentie van het extern en intern afwijkend behandelen van voorzieningen in accountantskantoren: $7 \%$ van het totaal) ten opzichte van het (overige) bedrijfsleven $6 \%{ }^{7}$ In geval van het internationaal georiënteerd bedrijf concentreren zich de verschillen tussen de externe en interne berichtgeving met name op afwijkende winstbepalingsstelsels. Typerend is dat in geval van een hoofdzakelijk

7 Gaat het hier om de verwerking van potentiele schadeclaims van ontevreden cliënten/gebruikers? 
nationaal opererend bedrijf de post voorzieningen in de externe respectievelijk interne berichtgeving relatief frequenter afwijkend wordt behandeld dan in geval van een internationaal opererend bedrijf (respectievelijk $10 \%$ en $4 \%$ van alle onderzochte gevallen). Mogelijk zijn de in internationaal verband opgestelde standaards ten aanzien van voorzieningen minder rekbaar dan de nationale wetgeving in dezen of kan via internationalisatie diversificatie van risico's worden bewerkstelligd.

Van de 124 respondenten gaf $60 \%$ aan dat er in de afgelopen 3 jaar in het interne berichtgevingssysteem belangrijke wijzigingen waren aangebracht. Hiermee wordt bevestigd dat de management accounting zich op dit moment in een soort stroomversnelling bevindt en wordt het belang benadrukt dat management accountants zich, meer dan vroeger, een creatief innoverende houding dienen aan te meten. Opvallend doch voor deze tijd niet verrassend is dat in de non-profit sector bijna $80 \%$ van de respondenten te kennen gaf dat belangrijke systeemaanpassingen in het interne berichtgevingssysteem waren doorgevoerd.

In de categorie '(overig) bedrijfsleven' was de verhouding tussen 'systeemaanpassingen/geen systeemaanpassingen' bijna 2 hetgeen eveneens wijst op een zekere veranderingsgezindheid.

Een internationaal werkterrein bleek geen extra accelerator te zijn voor systeemaanpassingen. In de groep 'internationaal opererende bedrijven' bleek echter ruim $70 \%$ van de bedrijven systeemaanpassingen te hebben aangebracht, in de groep 'nationaal opererende bedrijven' was dit ruim 50\%. De aard van de gesignaleerde aanpassingen was zeer divers en liep uiteen van het invoeren van voor- en nacalculaties, via een aangepast transferprijssysteem tot het opnemen van niét-financiële gegevens in het interne systeem. Een duidelijke relatie in de gerapporteerde systeemaanpassingen en de aard van het bedrijf casu quo de bedrijfsoriëntatie was niet te onderkennen.

Meer dan de helft van de respondenten verwacht in de toekomst nieuwe belangrijke aanpassingen in het interne berichtgevingssysteem (zie vraag 9). In het (overig) bedrijfsleven gaf ruim $60 \%$ van de respondenten werkzaam in deze sector aan dat aanpassingen worden verwacht, voor de non-profit sector was dit bijna $80 \%$ en ook de overheid scoort met bijna $80 \%$ zeer hoog. Bij verwachte belangrijke systeemaanpassingen bleek een internationaal karakter van een bedrijf eerder een rem op, dan een stimulator voor systeemaanpassingen te zijn. De gerapporteerde aard van de verwachte aanpassingen was zeer uiteenlopend. De meest frequent verwachte aanpassingen liggen op het terrein van 'performance measurement'.

Bijna $80 \%$ van de 119 in dit verband ondervraagde accountants en controllers is van mening dat de huidige interne berichtgeving te wensen overlaat (zie vraag 13)! Control- 
lers zijn deze mening meer toegedaan dan accountants (bij de accountants is $75 \%$ ontevreden, bij de controllers ruim $83 \%$ ). Typerend zijn hierbij de non-profit- en de overheidssector. In beide sectoren zijn respectievelijk $90 \%$ en $100 \%$ van de respondenten van mening dat de bestaande interne berichtgevingssystemen niet naar wens functioneren. De ratio nationaal/internationaal ten aanzien van de ontevredenheid met bestaande interne berichtgevingssystemen bedroeg bijna $1 \frac{1}{1} 2$. In het algemeen bleek deze ontevredenheid op te lopen met de duur van het dienstverband (zie vraag 3 ). Wijst dit op voortschrijdend inzicht of op een toenemende 'resistance for change' in de organisatie naarmate een systeem gedurende langere tijd in gebruik is?

Op vraag 14 betreffende de wijze waarop interne berichtgevingssystemen zouden kunnen worden verbeterd, antwoordde $23 \%$ van de 57 respondenten dat dit zou kunnen door meer en beter opgeleide mensen. Bijna $20 \%$ gaf te kennen dat dit zou kunnen door meer voorspellende waarde aan de gegevens toe te voegen. Andere factoren die werden genoemd zijn (1) snelheid van de gegevensverstrekking opvoeren (12\%), automatisering $(11 \%)$, het toevoegen van niét-financiële gegevens $(9 \%)$, het opvoeren van de betrokkenheid van het management casu quo de totale organisatie bij de management accounting, tot uitdrukking komend in onder andere een integrale informatieplanning (7\%), meer externe gerichtheid (concurrenten, strategie) (7\%), meer gerichtheid op kritieke succesfactoren $(7 \%)$ en het ontwikkelen van een 'early warning' element in het management accountingsysteem (4\%).

Van de 119 respondenten is de helft van mening dat een financieel feit met toekomstige effecten zoals een loonafspraak, in de boekhouding dan wel anderszins in de bedrijfsadministratie dient te worden verwerkt hetgeen dan ook in vrijwel de zelfde mate in de praktijk gebeurt (zie vraag 12$)^{8}$. Een vierde van de respondenten dat een dergelijk feit wel zou willen verwerken, doet dit op dit moment evenwel nog niet. Het percentage controller-respondenten dat dergelijke feiten administratief zou willen verwerken, ligt duidelijk hoger dan het percentage accountant-respondenten dat een dergelijke verwerking zou willen voorstaan ( $68 \%$ versus $41 \%$ ). Meestal vindt de verwerking plaats in het budgetsysteem en (derhalve) extracomptabel. Van de respondenten die aangaven dat dergelijke feiten op dit moment niet in hun bedrijfsadministratie worden verwerkt, gaf het overgrote deel te kennen dat het door hen ook niet van belang werd geacht dergelijke gegevens in een boekhouding te verwerken.

\footnotetext{
${ }^{8}$ De interpretatie van vraag 12 leverde bij een aantal respondenten de nodige problemen op, met name ten aanzien van het onderscheid boekhouding/bedrijfsadministratie/management accounting en met betrekking tot een intracomptabele respectievelijk extracomptabele verwerking van prospectieve gegevens. Hier strookt het exploratieve karakter van de vragen niet met de gevolgde kwantitatieve onderzoekmethode.
} 


\subsection{Samenvatting}

Hartman geeft aan dat de kwaliteit van de informatie meer is dan betrouwbaarheid alleen. Binnen de traditionele administratieve organisatie ligt het accent op deze betrouwbaarheid, maar het waarborgen van enkele van de andere kenmerken is vaak veel belangrijker voor de voortgang van het primaire proces binnen de organisatie respectievelijk voor het nemen van de goede managementbeslissingen (Hartman, 1993:378). Hartman pleit in dit verband voor het vervangen van het vak administratieve organisatie (AO) door een vak 'Organisatie van de Informatieverzorging' (OIV) waarbij optimale behandeling van gegevens uitgangspunt is zodat deze gegevens voor kwalitatief hoogstaande gegevensverstrekking kunnen dienen. Het conceptual framework zoals dat binnen de financial accounting wordt gebruikt, kan ook te dien aanzien goede diensten bewijzen.

Accountants besteden een steeds groter deel van hun werkzaamheden aan de interne berichtgeving (management accounting). Naast aandacht voor dit vakgebied in hun opleiding vereist dit een andere attitude en afweging ten aanzien van gegevenskwaliteiten zoals betrouwbaarheid en relevantie. Wanneer interne berichtgevingssystemen hoofdzakelijk worden opgezet vanuit aspecten als 'controleerbaarheid' en 'verifieerbaarheid', dan zijn vele van deze systemen tot mislukken gedoemd, dat wil zeggen: in vele gevallen zal sprake zijn van 'voorspelbare irelevantie'. Het prospectieve element in de interne berichtgeving en genoemde gegevenskarakteristieken zijn immers niet of slechts ten dele verenigbaar. De in dit verband noodzakelijke gegevens-perceptionele aanpassing van accountants respectievelijk controllers is evenwel nog slechts beperkt ontwikkeld.

Interne berichtgevingssystemen bevinden zich duidelijk in een fase van overgang. Relatief veel bedrijven hebben hun systeem in de afgelopen drie jaar op belangrijke onderdelen aangepast en de verwachting is dat deze ontwikkeling zich in de nabije toekomst zal voortzetten. Veel heil wordt verwacht van het verbeteren van de opleiding van financiële functionarissen en in het toevoegen van voorspellende waarde aan het management accountingsysteem. Het triple-entry accounting onderzoek kan een zinvolle bijdrage leveren om met name deze laatste gedachte te implementeren. 
:

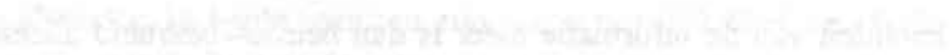

and

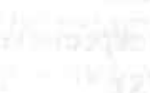

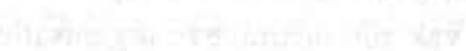



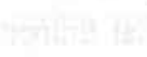






\section{Winstkrachten en de ontwikkeling van de winstcapaciteit van het eigen vermogen}

"De belangrijkste ontdekkingen komen van mensen die buiten de normale grenzen van hun specialisme bezig zijn"(Gleick, 1987:40).

\subsection{Inleiding; dimensieanalyse in de accounting ${ }^{1}$}

Onder andere Baxter en Flamholtz zien niet veel heil in het stellen van nieuwe eisen aan bestaande accountingsystemen, zoals het kunnen voorspellen van toekomstige winst en het ondersteunen van beleggers in hun beslissingen. Baxter vergelijkt dit met een poging een paard viool te laten spelen (Baxter in Edwards, 1987:5). Flamholtz merkt in dit verband op:

"What will be required will be the development of a new paradigm among managerial accountants" (1992:32).

Dit betekent dat in nieuwe informatiebehoeften slechts dan kan worden voorzien wanneer bestaande accountingsystemen worden aangepast. De mate waarin aanpassingen nodig zijn, is afhankelijk van de aard van de nieuwe informatiewensen. In het algemeen kan worden gesteld dat er een toenemende behoefte bestaat aan toekomstgerichte gegevens ${ }^{2}$.

"Investors and others want and expect more: more predictive and value-based information; more of the whys - not simply whats - of financial data" (Mednick, 1992:556).

\footnotetext{
${ }^{1}$ De dimensieanalyse is een tak van wiskundige analyse, ontwikkeld door fysici. Dimensies worden hierbij opgevat als een code die ons laat zien hoe de getalwaarde van een grootheid verandert, indien de fundamentele maateenheden voorgeschreven wijzigingen ondergaan (de Jong, 1975:1-3). De dimensieanalyse houdt zich bezig met de algemene vormvereisten van vergelijkingen waarmee men de betrekkingen tussen de relevante grootheden beschrijft. Wanneer een vergelijking dimensioneel niet homogeen is, duidt dit op een onjuistheid (onvolledigheid) in de theorie. Wanneer de waarde van verschillende grootheden (zoals appels en peren) wordt uitgedrukt in een zelfde maatbegrip (zoals kilogrammen), dan kunnen op deze grootheden allerlei rekenkundige bewerkingen worden uitgevoerd omdat ze dan dimensioneel homogeen zijn.

Als gronddimensies voor algemeen economische grootheden onderscheidt De Jong (1975:49):

1) geldvoorraden $(M)$

2)goederenvoorraden $(R)$ en

3)de tijd (T)

Voorraadgrootheden hebben de dimensie (M) of $(\mathrm{R})$ terwijl stroomgrootheden de dimensie $\mathrm{MT}^{-1}$ of $\mathrm{RT}^{-1}$ hebben. Uit de basisdimensies kunnen samengestelde dimensies worden afgeleid, zoals bijvoorbeeld een prijs die het quotiënt is van geldvoorraad en goederenvoorraad $\left(M^{-1}\right)$. Zie ook Vernooij (1993:463).

${ }^{2}$ Overigens betekent dit vaak dat gegevens over achterliggende oorzaken worden gewenst. Indien deze oorzaken bekend zijn, kan een gefundeerder uitspraak worden gedaan over de toekomstige ontwikkeling.
} 
De huidige accountingsystemen kunnen niet of nauwelijks systematisch in dergelijke informatiebehoeften voorzien, vooral niet omdat historisch gezien deze systemen niet op dergelijke behoeften zijn geënt (zie paragraaf 3.2).

Ook Ijiri is van mening dat het op onderdelen aanpassen van de bestaande accountingsystemen in vele gevallen niet veel soelaas biedt. Ijiri ziet veel meer heil in het op fundamentele wijze bijstellen van het aloude accountingraamwerk door het te dien aanzien ontwikkelen van nieuwe dimensies.

"It seems to be much more fruitful for us to return to the period of single-entry bookkeeping and start from scratch in developing accounting theories and practices in new dimensions than to adjust current accounting theories and practices here and there" (Ijiri, 1966:163).

Ijiri houdt zich al zo'n 35 jaar bezig met triple-entry accounting ${ }^{3}$, dat wil zeggen: dubbel of tweevoudig boekhouden uitgebreid met een derde dimensie die logischerwijze uit de bestaande twee dimensies kan worden afgeleid. In het algemeen worden 'samenstelling' en 'omvang' van het eigen vermogen gezien als de twee gronddimensies die bestaan in het dubbel boekhouden (zie ook hoofdstuk 1 paragraaf 1.1 en bijvoorbeeld Blommaert et al, 1989:70) ${ }^{4}$.

Onder samenstelling van het eigen vermogen wordt verstaan de opsomming (van de geldswaarde van de) (hoeveelheden) van de activa waarin het eigen vermogen is geïnvesteerd alsmede van de (geldswaarde van de) (hoeveelheden) verplichtingen die zijn aangegaan voor het verwerven van deze activa. Het betreft hier een administratie van de vermogensbestanddelen, zijnde bezittingen en schulden waaruit per saldo de omvang van het eigen vermogen kan worden vastgesteld. De overzichten die hierbij worden gebruikt, worden rekeningen van vermogenshestanddelen genoemd. Periodiek wordt uit deze rekeningen de balans opgemaakt (na omrekening van de hoeveelheden in guldens ${ }^{5}$ ) en kan de actuele omvang van het eigen vermogen (per saldo) worden vastgesteld. Afgezien van bepaalde vermogenstransacties zoals privé-acties of aandelenemissies, kan de mutatie welke in een bepaalde periode in de omvang van het eigen vermogen is opgetreden, als het resultaat (winst of verlies) van die periode worden beschouwd. Derhalve wordt bij

\footnotetext{
${ }^{3}$ Eir kan een onderscheid worden gemaakt tussen een boekhoudsysteem en een accountingsysteem. Strikt genomen is een boekhoudsysteem onderdeel van het accountingsysteem (zie paragraaf 2.2 en 3.3). Zo kan ook een onderscheid worden gemaakt tussen triple-entry bookkeeping en triple-entry accounting. Het praktisch implementeren van de derde dimensie, met name bij het in paragraaf 5 van dit hoofdstuk te bespreken differential triple-entry accountingsysteem, brengt evenwel dermate veel waarderingswraagstukken met zich mee (meer dan registratievraagstukken), dat beter kan worden gesproken van triple-entry accounting dan van triple-entry bookkeeping. ljiri (1989) spreekt overigens van 'momentum accounting and triple-entry bookkeeping'.

${ }^{4}$ Feitclijk dient hierbij tevens de factor 'tijd' als gronddimensie te worden genoemd.

${ }^{5}$ Dit waarderingsvraagstuk dient eigenlijk tot de accounting te worden gerekend en niet tot het boekhouden, althans het boekhouden in enge zin. In deze laatste beradering is boekhouden puur cen registratief (gegevensverwerkend) proces.
} 
enkel boekhouden het resultaat, zijnde een stroomgrootheid, via een omweg bepaald door het meten van mutaties in voorraden.

Onder omvang van het eigen vermogen wordt verstaan de totale geldswaarde van het nominaal geplaatst aandelenvermogen, de reserves en de ingehouden winst (of in plaats van de laatste post respectievelijk kosten en opbrengsten $)^{6.7}$. Het type rekeningen waarop de mutaties in deze posten worden geadministreerd, wordt vermogensrekeningen genoemd. Het saldo van de rekeningen van de vermogensbestanddelen dient gelijk te zijn aan het saldo van de vermogensrekeningen.

Ten behoeve van het onderzoek naar een derde dimensie lijkt de genoemde tweedeling van het eigen vermogen 'samenstelling-omvang' in eerste instantie minder geschikt. Samenstelling en omvang en ...? Desalniettemin zullen deze dimensies de centrale thema's blijken te zijn van het dubbel boekhouden.

Bij dubbel boekhouden wordt de omvang van het eigen vermogen op twee manieren geadministreerd: 1) indirect via de samenstellende delen en 2) direct via het administreren van resultaten (en dus stroomgrootheden). Dubbel boekhouden is het administreren van voorraden (of 'stock') en stromen (of 'flows'). Het gevolg van 'stroming' is een verandering in een voorraad: een toe- of afname van de omvang van het eigen vermogen.

Gecumuleerde stroming uit het verleden geeft een verklaring voor de voorraad zoals die per een bepaald moment in het heden bestaat.

Ijiri noemt de dimensies 'stock' en 'flow' de basisdimensies van het dubbel boekhouden. De relatie tussen deze dimensies is als volgt:

'The present is fully accounted for by the past:

stock $=\Sigma$ flow" (Ijiri, 1989:43)

Maar de dimensies 'stock' en 'flow' (of voorraad en stroming) zijn in feite de dimensies samenstelling en omvang van het eigen vermogen. Immers er geldt:

'stock' ${ }_{2}$ - 'stock' ${ }_{1}=\Delta$ samenstelling $=$ 'flow' $=\Delta$ omvang

Hierbij staat het symbool $\triangle$ voor 'verandering in'.

\footnotetext{
${ }^{6}$ De aard van deze posten is afhankelijk van de ondememingsvorm.

${ }^{7}$ Zoals in paragraaf 1.1 opgemerkı gaat het hierbij feitelijk om de onrwikkeling van de omvang van het eigen vermogen en derhalve ook om de ontwikkeling in genoemde posten.
} 
In meerdere publikaties heeft Ijiri geprobeerd aan te tonen dat de bestaande twee dimensies in het dubbel boekhouden ('stock' en 'flow') feitelijk een imperfect deel zijn van een natuurlijke triniteit (Ijiri, 1982, 1989). Wanneer zijn poging geslaagd mag worden genoemd, falsifieert ljiri de perfectie-hypothese zoals die ten aanzien van het dubbel boekhouden wordt aangehouden. Deze hypothese houdt concreet in dat het systeem van dubbel boekhouden niet met enige dimensie kan worden uitgebreid, zonder de interne logica van het systeem aan te tasten.

In dit hoofdstuk wordt het werk van Ijiri in ruime mate aan de orde gesteld. Op een aantal punten wordt dit werk aangevuld, met name ten aanzien van de gebruikte natuurkundige achtergronden, alsmede ten aanzien van de modelmatige implementatie (operationalisering) van triple-entry en momentum accounting.

\subsection{Zoektocht naar de derde dimensie: een eerste verkenning}

Om beter aan de informatiewensen van gebruikers te kunnen voldoen, heeft ljiri voorstellen ontwikkeld om het bestaande accountingmodel aan te passen. De verwachting is dat door administratie van de derde dimensie - deze dimensie betreft de oorzaken van ontwikkelingen in resultaatposten (anders gezegd: oorzakelijke winstmutaties) - aan een groot deel van de thans onvervulde informatiewensen kan worden tegemoet gekomen. Ijiri vindt het twijfelachtig dat waar in de organisatietheorie inmiddels wordt uitgegaan van diverse partijen met uiteenlopende doelstellingen die alle tegelijkertijd dienen te worden gerealiseerd ('the behavioral concept of the firm'), de accounting kan blijven bestaan in het administreren van slechts twee dimensies (Ijiri, 1966:163). Ijiri denkt met een nieuw uitgebreid accountingmodel beter te kunnen voldoen aan de eisen die aan de huidige accounting worden gesteld.

Wat de doelstelling(en) van accounting betreft kan het volgende worden opgemerkt.

"The basic objective of accounting is to provide information useful for making economic decisions. An objective of financial statements is to provide users with information for predicting, comparing, and evaluating enterprise earning power" (AICPA, 1973:13-24).

Opvallend hierbij is de aanwijzing van 'earning power' in plaats van 'winst' als belangrijkste item waarover gegevens dienen te worden verstrekt.

Bij 'earning power' gaat het niet zo zeer om de vraag welk winstniveau in het verleden is gerealiseerd, maar (vooral) om de vraag of het bedriff deze winst in de toekomst kan blijven genereren. Dit laatste aspect impliceert een bepaald winstpotentieel of een bepaalde winstcapaciteit. Ijiri noemt dit potentieel 'income momentum'. Het gaat derhalve 
hierbij niet om de winst van enig jaar (als absoluut getal in guldens) maar (vooral) ook om de vraag of dit winstcijfer kan worden geïnterpreteerd als 'winst per jaar'. Dit laatste impliceert een continu winstpotentieel.

Vanzelfsprekend heeft het toevoegen van een derde dimensie gevolgen voor datgene wat onder een financieel feit dient te worden verstaan. Een financieel feit is bepalend voor het moment waarop tot registratie dient te worden overgegaan. In het enkel boekhouden is een financieel feit 'elke bedocumenteerde gebeurtenis waardoor de samenstelling van het eigen vermogen verandert'. Hierbij wordt de omvang van het eigen vermogen 'per saldo' gemuteerd. Bij dubbel boekhouden is een financieel feit 'elke bedocumenteerde gebeurtenis waardoor de samenstelling en/of de omvang van het eigen vermogen verandert'.

In triple-entry accounting onderscheidt Ijiri twee vormen (1982:45): 'temporal triple-entry accounting' en 'differential triple-entry accounting'. 'Temporal triple-entry accounting' kan worden omschreven als 'intracomptabele budget-administratie' (zie voor een uitwerking van dit systeem paragraaf 7.4). 'Differential triple-entry accounting ' kan worden omschreven als 'intracomptabele administratie van de gerealiseerde effecten van winstkrachten ${ }^{8}$ (zie voor een uitwerking van dit systeem de paragrafen 7.5.4 en 8.4).

Bij temporal triple-entry accounting is een financieel feit 'elke bedocumenteerde gebeurtenis waardoor de huidige samenstelling enlof huidige omvang en/of te realiseren toename van de omvang van het eigen vermogen verandert' ${ }^{\prime}$. Door bijvoorbeeld een bepaalde omzet te realiseren zal zowel de samenstelling van het eigen vermogen veranderen (de post debiteuren of liquide middelen zal toenemen terwijl de voorraden verminderen), als de (gerealiseerde) omvang van het eigen vermogen (het eigen vermogen neemt toe met het netto-resultaat op de betreffende verkoop), als ook de te realiseren toename van de omvang van het eigen vermogen (deze neemt af met het netto-verkoopresultaat).

Bij differential triple-entry accounting is een financieel feit 'elke bedocumenteerde gebeurtenis waardoor de huidige samenstelling enlof huidige omvang enlof winstcapaciteit van het eigen vermogen verandert'. Het failliet gaan van een belangrijke klant is in een gangbare twee-dimensionale administratie, afgezien van eventueel af te schrijven vorderingen, géén financieel feit. In een drie-dimensionale administratie dient evenwel, ten einde de veranderde winstcapaciteit van het eigen vermogen tot uitdrukking te

\footnotetext{
8 'Differential triple-entry accounting' zou men kunnen aanduiden als 'activity based accounting' omdat in dit systeem wordt getracht een verklaring te geven voor het in een bepaalde periode gerealiseerde resultaat, voor zover dit althans afwijkt van het in de vorige verslagperiode gerealiseerde resultaal. Hiervoor dient men de 'profit-drivers' (winstkrachten) op te sporen.

${ }^{9}$ In geval een voorzienbaar verlies is de begrote toename van het eigen vermogen negatief.
} 
brengen, het verlies aan winstpotentieel dat met het failleren van deze klant gepaard gaat, te worden omgerekend en geadministreerd ${ }^{10}$.

Veranderingen in de winstcapaciteit van het eigen vermogen vinden plaats door het optreden van (veranderingen in) winstkrachten. Een winstkracht is de oorzaak van een bepaalde mutatie in de winst. In een differential triple-entry accountingsysteem worden de gerealiseerde effecten van deze winstkrachten intracomptabel geadministreerd zodat op systematische wijze een sluitende verklaring kan worden gegeven voor de verandering in de hoogte van het periodieke resultaat. In een momentum accountingsysteem worden de effecten van de winstkrachten uitgedrukt in winstsnelheden, dat wil zeggen: in winstmutaties per jaar. Concreet is het verschil tussen differential triple-entry accounting en momentum accounting het volgende: bij differential triple-entry accounting worden uitsluitend de gerealiseerde effecten van winstkrachten geadministreerd ${ }^{11}$ terwijl bij momentum accounting de effecten van winstkrachten worden geadministreerd, ongeacht of deze al dan niet zijn gerealiseerd. Een voorbeeld moge dit verduidelijken. Stel een bedrijf sluit per 1 september 1994 een nieuwe verzekering af tegen een premie van $f$ 6.000 ,- per jaar. In het differential triple-entry accountingsysteem wordt het effect van deze negatieve winstkracht verwerkt als $4 / 12 \times f 6.000,-=f 2.000$,- aan extra kosten over 1994. Afgezien van andere factoren is deze $f 2.000$,- tevens de verklaring voor de afname van de winst in 1994 ten opzichte van de winst in 1993. Maar het andere informatieve aspect van 'extra kosten op jaarbasis $f 6.000,-$ ', wordt in het differential triple-entry accountingsysteem niet vastgelegd. Dit gebeurt wél in het momentum accountingsysteem waarin de afname van de winstcapaciteit op jaarbasis ${ }^{12}$ (winstsnelheid) wordt geadministreerd.

Wanneer een bedrijf eenmaal heeft gekozen voor het administreren van winstkrachten, is de afstand van differential triple-entry accounting naar momentum accounting niet meer zo groot. Het is dan nog een dimensionale kwestie: de winsteffecten uitdrukken in 'guldens in een jaar' of 'kosten per jaar' (Vernooij, 1993:464). Op een bepaalde wijze kunnen differential triple-entry accounting en momentum accounting in één systeem worden verenigd. Dit kan door voor de ontwikkeling in de momenta een aparte subadministratie te voeren dan wel door in de hoofdadministratie afzonderlijk niet-gerealiseerde winstkrachten te administreren (zie hoofdstuk 8).

\footnotetext{
${ }^{10}$ De FASB heeft in statement nummer 6 cen feit of 'event' gedefinieerd als 'a happening of consequence to an entity'(FASB, 1985:46). Het niet administreren van het wegvallen van bedoelde klant, waartoe de twee-dimensionale administratie feitelijk leidt, is min of meer in tegenspraak met deze verklaring.

${ }^{11}$ Dit gebeurt om aansluiting te verkrijgen met het winstcijfer. Winstcijfer en effecten van winstkrachten zijn op deze manier dimensioneel homogeen.
}

${ }^{12}$ Enige andere periode-aanduiding is ook mogelijk. 
Met de aangepaste definitie van 'financieel feit' in een triple-entry accountingsysteem dient ook de theorie van het boekhouden te worden aangepast. Onder een theorie van het boekhouden wordt verstaan een verklaring voor het debiteren en crediteren van de rekeningen in het grootboek. De zaak-theorie en de twee-rekeningen reeksen-theorie worden tegenwoordig overwegend aangehangen (van Liempt et al, 1989:324-328). In de zaak-theorie wordt het eigen vermogen als een schuld gepresenteerd: een schuld van de zaak aan de eigenaar. Aangezien dit in het geval van niét-rechtspersoonlijkheid bezittende ondernemingen een fictie is en bovendien het presenteren van eigen vermogen als een schuld (vreemd vermogen) uit financieringsoogpunt misleidend kan zijn, wordt hierna uitsluitend van de twee-rekeningen reeksen-theorie uitgegaan. De twee reeksen van rekeningen die men in deze theorie onderscheidt zijn:

1) rekeningen van vermogensbestanddelen (voor het administreren van de mutaties in de vermogenssamenstelling) en

2) vermogensrekeningen (voor het administreren van de mutaties in de vermogensomvang).

De belangrijkste vermogensrekeningen zijn de verlies-en winstrekeningen omdat deze de ontwikkeling in het operationele bedrijfsresultaat beschrijven. Naast verlies- en winstrekeningen kunnen vermogensrekeningen als 'Aandelenvermogen' en 'Reserves' voorkomen. Hierbij gaat het met name om ontwikkelingen in de omvang van het eigen vermogen uit hoofde van financieringsactiviteiten en winstdeling.

De boekingsregels in een twee-dimensionale administratie bij het gebruik van genoemde twee reeksen van rekeningen luiden:

1) Een grootboekrekening van een vermogensbestanddeel wordt gedebiteerd bij toename en gecrediteerd bij afname van het eigen vermogen.

2) Een vermogensrekening wordt gecrediteerd bij toename en gedebiteerd bij afname van het eigen vermogen.

Expliciet worden in deze regels de gevolgen geanalyseerd van financiële feiten op de omvang van het eigen vermogen. Veranderingen in de samenstelling van het eigen vermogen, zoals bijvoorbeeld bij de betaling per bank door een afnemer, worden enerzijds uitgelegd als een toename van de omvang van het eigen vermogen (de ontvangst van het betreffende geld) en anderzijds als een afname van de omvang van het eigen vermogen (het wegvallen van de vordering).

In dit en het volgend hoofdstuk worden de hiervoor gestelde boekingsregels volgens de twee-rekeningen reeksen-theorie aangepast ten behoeve van de drie-dimensionale administratie. 
Met name differential triple-entry accounting wordt door Ijiri zeer gedetailleerd uitgewerkt. Hierbij maakt hij gebruik van ontwikkelingen die zich in de natuurkunde hebben voorgedaan. Om de achtergronden van differential triple-entry accounting goed te kunnen inzien, worden in dit hoofdstuk de belangrijkste ontwikkelingen in de natuurkunde kort uiteengezet. Maar vooraleerst is het van belang de merites van het tweevoudig boekhouden aan een nadere analyse te onderwerpen. Hierbij dient te worden opgemerkt dat, alvorens van een derde dimensie en derhalve van een uitbreiding van het bestaande accountingsysteem kan worden gesproken, uit theoretisch-wetenschappelijk oogpunt aan twee voorwaarden dient te worden voldaan (Ijiri, 1982:2):

\section{1) Instandhoudingseis.}

Alles wat in het bestaande systeem aanwezig is, moet ook door het nieuwe systeem worden afgedekt.

2) Integriteitseis.

De nieuwe dimensie moet op logische wijze uit de bestaande dimensies kunnen worden afgeleid en derhalve een integrerend deel uitmaken van het nieuwe systeem. Dit betekent bijvoorbeeld dat plaats, leeftijd, actuele waarde geen derde dimensie kunnen vormen in de zin van een triple-entry accountingsysteem. Dergelijke 'attributen' berusten meer op persoonlijke voorkeur en zijn derhalve uit theoretisch oogpunt ongeschikt om als derde dimensie te dienen. Een derde dimensie die berust op de regels van de logica heeft immers meer kans algemeen te worden geaccepteerd.

Fraser heeft vergaande kritiek op deze integriteitseis zoals geformuleerd door ljiri.

"Therefore, purely on logical grounds and ignoring problem-solving considerations, the integrity criterion does not give a unique answer to the extension problem and is therefore incomplete" (Fraser, 1993:154).

Om zijn stelling te onderbouwen gebruikt Fraser het voorbeeld waarbij de eerste dimensie het getal 1 is en de tweede dimensie het getal 2 . Welke relatie bestaat er nu tussen beide dimensies en welke gevolgen heeft deze relatie voor de derde dimensie, dit is het derde getal? In een eerste geval is het getal 2 (de tweede dimensie) verkregen door bij het getal 1 nog eens 1 op te tellen. De derde dimensie wordt dan $2+1=3$. In een tweede geval is het getal 2 verkregen door het getal 1 met 2 te vermenigvuldigen. De derde dimensie wordt dan $2 \times 2=4$. In een derde geval is de tweede dimensie verkregen door het getal 1 te kwadrateren en daar nog eens 1 bij op te tellen. De derde dimensie wordt dan $2^{2}+1=5$. Meerdere situaties zijn denkbaar. Maar doet dit nu afbreuk aan de integriteitseis, zeker wanneer men deze ziet in relatie met de instandhoudingseis?

Natuurlijk is het derde getal afhankelijk van de relatie die bestaat tussen de eerste twee getallen. Maar wanneer deze relatie eenmaal is vastgesteld (en ljiri beschrijft op grondige 
wijze de relatie tussen de eerste twee dimensies van accounting alsmede test hij grondig de houdbaarheid van deze relatie) en wordt doorgetrokken naar het derde getal ${ }^{13}$, volgt toch een unieke waarde voor de derde dimensie? Derhalve is deze kritiek van Fraser ongegrond.

Waar Fraser terecht op wijst, is dat ljiri zonder meer aanneemt dat triple-entry accounting zinvol is. Maar wat is het nut van een dergelijk systeem?

"The objectives of any extension to the existing accounting framework should be specified in ex ante terms of the accounting needs and problems which it is hoped that the extension will help to solve or alleviate. This approach - notably lacking in ljiri's proposals and its most serious omission - is that of the FASB' Conceptual Framework..." (Fraser, 1993:157).

Het experiment waarvan de resultaten in hoofdstuk 9 zullen worden besproken, kan meer zicht geven op het nut van triple-entry en momentum accounting en derhalve op de (economische) verantwoording ervan.

\subsection{De twee dimensies in het dubbel boekhouden}

Accounting is niet het uitvoeren van een aantal op zich staande financiële metingen. Alle metingen vinden plaats binnen een bepaalde structuur of eenheid. De twee-eenheid in het dubbel boekhouden wordt gewoonlijk uitgedrukt in de vergelijking:

activa $=$ vermogen $[1]$

of als

activa $=$ eigen vermogen + vreemd vermogen [2]

Aan de ene kant van de vergelijking staan de produktiebronnen van de onderneming, aan de andere kant de claims die daarop door diverse partijen (eigenaren en schuldeisers) worden gelegd. Vergelijking [2] kan ook als volgt worden uitgeschreven:

activa - vreemd vermogen $=$ eigen vermogen $[3]^{14}$

\footnotetext{
${ }^{13}$ Het van toepassing verklaren van deze relatie op de derde dimensie is behalve cen kwestie van integriteit ook een kwestie van instandhouding.

${ }^{14}$ Dat de basisvergelijking van het dubbel boekhouden meestal niet in deze vorm wordt opgeschreven, heeft te maken met het vermijden van negatieve getallen.
} 
of als

netto activa $=$ eigen vermogen [4].

Ijiri duidt de netto activa aan als 'wealth'. Men zou dit kunnen vertalen als rijkdom. Enerzijds geeft het rechterlid van vergelijking [4] de omvang ervan aan en anderzijds specificeert het linkerlid van vergelijking [4] de delen waaruit de rijkdom bestaat (samenstelling). Hierbij zijn schulden als 'negatieve rijkdom' uitgelegd. Met het begrip 'wealth' als overschot van bezittingen over schulden wordt aangesloten bij datgene wat in de algemene economie gebruikelijk is bij het meten van de rijkdom van een land (zie bijvoorbeeld Samuelson, 1983:84).

Vergelijking [3] of [4] is te prefereren boven vergelijking [1] of [2] omdat de absolute waarde van het vreemd vermogen (zijnde claims) meer is gerelateerd aan activa dan aan het eigen vermogen.

Netto-activa kunnen per een bepaald tijdstip worden geïnventariseerd, het zijn reële posten. Derhalve geven de betreffende grootboekrekeningen de huidige (statische) financiele toestand weer van het bedrijf. De directe componenten van het eigen vermogen daarentegen (met name reserves en ingehouden winst) kunnen niet specifiek worden geïdentificeerd en geïnventariseerd. De huidige status van deze nominale posten kan alleen worden vastgesteld door een beschrijving te geven van ontwikkelingen die te dien aanzien in het verleden hebben plaatsgevonden.

De conclusies uit het voorgaande zijn dat:

1) rekeningen van vermogensbestanddelen (netto-activa) het heden beschrijven en derhalve een toestand;

2) vermogensrekeningen het verleden beschrijven en derhalve een ontwikkeling.

Vergelijking [4] kan nu ook als volgt worden geschreven:

$$
\text { heden }=\text { verleden }[5]^{15}
$$

Anders gezegd: De huidige financiële status van de onderneming wordt volledig verklaard door zich rekenschap te geven over het verleden. Dit is ook de toevoeging van het dubbel boekhouden ain het enkel boekhouden. Enkel boekhouden beschrijft uitsluitend de

\footnotetext{
${ }^{15}$ Deze vergelijking is dimensioneel heterogeen, immers het heden is een 'voorraadgrootheid' en het verleden een 'stroomgrootheid'. Om ze homogeen te maken kan men (1) de stroom vermenigvuldigen met een aantal tijdsperoden waardoor de stroom overgaat in een voorraad of (2) de voomad differentièren naar de tijd waardoor een stroom wordt verkregen.
} 
huidige financiële positie. Het verklaren van het heden door een beschrijving van het verleden te geven, gebeurt in het dubbel boekhouden systematisch en volledig. In tripleentry accounting zal ten aanzien van de derde dimensie het zelfde moeten gelden.

\subsection{Temporal triple-entry accounting}

\subsubsection{De dimensies in temporal triple-entry accounting}

Vergelijking [5] kan op natuurlijke wijze als volgt worden uitgebreid:

$$
\text { heden }=\text { verleden }=\text { toekomst }[6]
$$

In het geval 'toekomst' als derde, nieuwe dimensie wordt geadministreerd, is sprake van temporal triple-entry accounting. De nieuwe dimensie heeft betrekking op gebudgetteerde, geplande of geprojecteerde gebeurtenissen. Vergelijking [4] kan derhalve ook als volgt worden geschreven:

$$
\text { netto activa }=\text { eigen vermogen }=\text { budget [7] }
$$

Onder 'budget' zou hier kunnen worden verstaan het doelvermogen van de onderneming (het zogenaamde geprojecteerde eigen vermogen of 'target capital' ${ }^{16}$ ). Dit is de toekomstige omvang van het eigen vermogen van de onderneming wanneer alle budgetten worden gerealiseerd. Maar de term 'budget' is meestal gerelateerd aan een bepaalde periode en derhalve geen cumulatieve grootheid. Het budget is dan de voor een bepaalde periode te realiseren toename van het eigen vermogen.

Ten aanzien van deze nieuwe dimensie, budget of doelvermogen, geldt dat:

1) te realiseren opbrengsten (= begrote opbrengsten) negatief worden aangemerkt (zij vormen een budgetverplichting);

2) te realiseren kosten (= begrote kosten) positief worden aangemerkt (zij vormen een budgetrecht, de budgetruimte).

Aangezien de begrote opbrengsten de begrote kosten meestal zullen overtreffen, wordt de kolom budget per saldo met een negatief bedrag geopend. Dit saldo geeft als het ware het

\footnotetext{
${ }^{16}$ Er wordt in het vervolg steeds van uitgegaan dat een bepaald winstniveau wordt gebudgetteerd en derhalve dat een bepaalde toename van het eigen vermogen is begroot. Het doelgericht terugdringen van een bepaalde verliesgevende positie kan hiertoe evenwel ook worden gerekend (met verwisseling van de tekens bij de betreffende getallen).
} 
contract weer dat voor de komende periode is aangegaan ten aanzien van een bepaald te realiseren winstniveau.

De hiervoor gegeven regels ten aanzien van de budget-dimensie zijn geen boekingsregels ter verwerking van financiële feiten. Het gaat hierbij immers om het 'openen van de derde dimensie in het grootboek'. Het openen van het grootboek, zoals ook het afsluiten van het grootboek, vormt een formaliteit welke niet met behulp van regels behoeft te worden verklaard.

Voor gerealiseerde opbrengsten en kosten geldt in de kolom 'budget' het volgende:

1) gerealiseerde opbrengsten worden positief aangemerkt (zijnde afnamen van de te realiseren toename van het eigen vermogen en dus afnamen van budgetverplichtingen);

2) gerealiseerde kosten worden negatief aangemerkt (zijnde toenamen van de te realiseren toename van het eigen vermogen en dus afnamen van budgetruimte $)^{17}$.

We zullen thans, ten behoeve van de drie-dimensionale administratie, de eerder gegeven boekingsregels bij toepassing van de twee-rekeningen reeksen-theorie herformuleren. Hierbij worden (in de twee-dimensionale administratie) twee kolommen onderscheiden en wordt gebruik gemaakt van negatieve getallen. Het zijn deze vanuit een wetenschappelijk conceptmatig oogpunt belangrijke boekingsregels welke in het werk van Ijiri ontbreken en waardoor een brede toepassing wordt belemmerd.

1) Een debetkolom voor het registreren van mutaties in de netto activa ('wealth') en dus voor de samenstellende delen van het eigen vermogen. Het betreft hier de grootboekrekeningen van de vermogensbestanddelen.

2) Een creditkolom voor het registreren van mutaties in de omvang van het eigen vermogen. Het betreft hier de vermogensrekeningen.

De aangepaste boekingsregels volgens de twee-rekeningen reeksen-theorie in een tweedimensionale administratie luiden nu als volgt:

1) Een rekening van een vermogensbestanddeel wordt in de debetkolom met een positief getal ingevoerd wanneer het eigen vermogen ${ }^{18}$ toeneemt, respectievelijk in de debet-

\footnotetext{
${ }^{17}$ Gerealiseerde opbrengsten kan men aanmerken als 'negatieve begrote opbrengsten' en gerealiseerde kosten als 'negatieve begrote kosten',

${ }^{18}$ In plaats van 'eigen vermogen' kan men hier ook lezen 'netto actief'. Maar ondat het centrale object van administratie het eigen vermogen is, zijn alle boekingsregels hierop geënt.
} 
kolom met een negatief getal ingevoerd wanneer het eigen vermogen afneemt ${ }^{19}$.

2) Een vermogensrekening wordt in de creditkolom met een positief getal ingevoerd wanneer het eigen vermogen toeneemt, respectievelijk in de creditkolom met een negatief getal ingevoerd wanneer het eigen vermogen afneemt.

De tegenstelling in deze boekingsregels voor wat betreft de positieve en negatieve invoer zorgt voor handhaving van het evenwicht in het grootboek respectievelijk tussen de debeten creditkolom.

In geval van een drie-dimensionale administratie zoals bij temporal triple-entry accounting dient naast de debet- en creditkolom een derde kolom, trebit-kolom, te worden gebruikt $^{20}$. In een temporal triple-entry accountingsysteem is de trebit-kolom de budgetkolom waarin de ontwikkelingen in de begrote toename van het eigen vermogen worden geadministreerd. Hierbij kan zowel sprake zijn van begrote vermogensbestanddelen (zoals ten aanzien van kas-, voorraad- en debiteurenposities) als van begrote posities voor vermogensrekeningen (met name ten aanzien van opbrengsten en kosten) ${ }^{21}$.

De boekingsregel voor de trebit-kolom is voor wat betreft de begrote vermogensbestanddelen tegengesteld aan de regel die geldt voor de gerealiseerde vermogensbestanddelen (zie regel 1 hiervoor). Voor wat betreft begrote saldi op vermogensrekeningen is de boekingsregel voor de trebitkolom tegengesteld aan de boekingsregel die geldt voor de gerealiseerde vermogensrekeningen (zie regel 2 hiervoor). Een grootboekrekening waarop mutaties in het te realiseren bedrag van een vermogensrekening worden geadministreerd, wordt een begrote vermogensrekening, target-rekening of budgetrekening genoemd.

Wanneer nu in een temporal triple-entry accountingsysteem naast samenstelling en omvang van het eigen vermogen ook begrote saldi van vermogensrekeningen worden geadministreerd en derhalve ontwikkelingen in de realisatie van de begrote omvang van het eigen vermogen, dan komen er in het grootboek 3 soorten grootboekrekeningen voor en luiden de boekingsregels als volgt:

1) De gevolgen van een mutatie in een rekening van een vermogensbestanddeel worden in de debetkolom met een positief getal ingevoerd wanneer het eigen vermogen

\footnotetext{
${ }^{19}$ Desgewenst kunnen de vermogensbestanddelen worden onderverdeeld in positieve vermogensbestanddelen (bezittingen) en negatieve vermogensbestanddelen (schulden). In dit geval zullen er drie boekingsregels bestaan.

20 'Trebit' is een samensmelting van 'tre' (voor drie) en 'bit' (voor deeltje). De fonetische overcenkomst met 'debel'" en 'credit' spreekt voor zich.

${ }^{21}$ ljiri maakt geen onderscheid tussen begrote vermogens-bestanddelen en begrote posities op vermogensrekeningen. Ijiri werkt uitsluitend met begrote posities voor vermogensrekeningen. Maar de dimensie 'budget' kan in het kader van de financiële planning ook betrekking hebben op voorraadgrootheden zoals liquiditcits-, debiteuren- en voorraadposities.
} 
toeneemt, respectievelijk in de debetkolom met een negatief getal ingevoerd wanneer het eigen vermogen afneemt.

2) De gevolgen van een mutatie in een vermogensrekening worden in de creditkolom met een positief getal ingevoerd wanneer het eigen vermogen toeneemt, respectievelijk in de creditkolom met een negatief getal ingevoerd wanneer het eigen vermogen afneemt.

3) De gevolgen van een mutatie in een budgetrekening worden in de trebitkolom met een positief getal ingevoerd wanneer het eigen vermogen toeneemt (respectievelijk de te realiseren toename van het eigen vermogen afneemt), en in de trebitkolom met een negatief getal ingevoerd wanneer het eigen vermogen afneemt (respectievelijk de te realiseren toename van het eigen vermogen toeneemt).

Men kan hier spreken van een drie-rekeningen reeksentheorie zoals deze geldt bij temporal triple-entry accounting, dat wil zeggen: budget-georiënteerde administratie.

In tabel 7.1 zijn de boekingsregels bij temporal triple-entry accounting volgens de drierekeningen reeksen-theorie nader gedetailleerd. Hierbij zijn de rekeningen van de vermogensbestanddelen, de vermogensrekeningen en de budgetrekeningen onderverdeeld in positieve en negatieve rekeningen. Positieve rekeningen van vermogensbestanddelen betreffen de activa, negatieve rekeningen van vermogensbestanddelen betreffen posten van het vreemd vermogen. Positieve vermogens- en budgetrekeningen hebben betrekking op opbrengstrekeningen, negatieve vermogens- en budgetrekeningen hebben betrekking op rekeningen van kosten.

De gegeven boekingsregels zorgen voor handhaving van de gelijkheid in vergelijking [7] en als zodanig ook voor gelijke tellingen van de debet-, credit- en trebitkolom. Aan de hand van een eenvoudig voorbeeld zal nu de gegevensverwerking in een temporal tripleentry accountingsysteem nader worden toegelicht. 
Tabel 7.1 Gedetailleerde boekingsregels bij temporal triple-entry accounting.

\begin{tabular}{|c|c|c|c|}
\hline & $\begin{array}{l}\text { mutatie in } \\
\text { betreffende } \\
\text { post }\end{array}$ & $\begin{array}{l}\text { mutatie in de } \\
\text { omvang van } \\
\text { het eigen } \\
\text { vermogen }\end{array}$ & $\begin{array}{l}\text { aan- } \\
\text { tekening } \\
\text { in het } \\
\text { journaal }\end{array}$ \\
\hline $\begin{array}{l}\text { 1a.positief vermogensbestand- } \\
\text { deel } \\
\text { (bijvoorbeeld kas) }\end{array}$ & $\begin{array}{l}\text { Toename } \\
\text { Afname }\end{array}$ & $\begin{array}{l}\text { Toename } \\
\text { Afname }\end{array}$ & $\begin{array}{l}\text { Debet + } \\
\text { Debet - }\end{array}$ \\
\hline $\begin{array}{l}\text { lb.negatief vermogensbestand- } \\
\text { deel } \\
\text { (bijvoorbeeld crediteuren) }\end{array}$ & $\begin{array}{l}\text { Toename } \\
\text { Afname }\end{array}$ & $\begin{array}{l}\text { Afname } \\
\text { Toename }\end{array}$ & $\begin{array}{l}\text { Debet - } \\
\text { Debet + }\end{array}$ \\
\hline $\begin{array}{l}\text { 2a.positieve vermogensrekening } \\
\text { (bijvoorbeeld huuropbrengsten) }\end{array}$ & $\begin{array}{l}\text { Toename } \\
\text { Afname }\end{array}$ & $\begin{array}{l}\text { Toename } \\
\text { Afname }\end{array}$ & $\begin{array}{l}\text { Credit + } \\
\text { Credit - }\end{array}$ \\
\hline $\begin{array}{l}\text { 2b.negatieve vermogensrekening } \\
\text { (bijvoorbeeld loonkosten) }\end{array}$ & $\begin{array}{l}\text { Toename } \\
\text { Afname }\end{array}$ & $\begin{array}{l}\text { Afname } \\
\text { Toename }\end{array}$ & $\begin{array}{l}\text { Credit - } \\
\text { Credit + }\end{array}$ \\
\hline $\begin{array}{l}\text { 3a.positieve budgetrekening } \\
\text { (bijvoorbeeld te realiseren huur- } \\
\text { opbrengsten) }\end{array}$ & $\begin{array}{l}\text { Toename } \\
\text { Afname }\end{array}$ & $\begin{array}{l}\text { Afname } \\
\text { Toename }\end{array}$ & $\begin{array}{l}\text { Trebit - } \\
\text { Trebit + }\end{array}$ \\
\hline $\begin{array}{l}\text { 3b.negatieve budgetrekening } \\
\text { (bijvoorbeeld te realiseren loon- } \\
\text { kosten) }\end{array}$ & $\begin{array}{l}\text { Toename } \\
\text { Afname }\end{array}$ & $\begin{array}{l}\text { Toename } \\
\text { Afname }\end{array}$ & $\begin{array}{l}\text { Trebit + } \\
\text { Trebit - }\end{array}$ \\
\hline
\end{tabular}

\subsubsection{De verwerking van gegevens in een temporal triple-entry accountingsysteem}

Veronderstel dat een bedrijf over 100 actief beschikt, 50 in kas en 50 aan goederen. Hiervan is 40 aan te merken als eigen vermogen (reserves) en 60 als vreemd vermogen. Voor de komende budgetperiode is een omzet begroot van 50 bij een bedrag van 30 aan kosten. Het doelvermogen is in dit geval te berekenen door de aanwezige reserves te verhogen met de begrote omzet ad 50 minus de begrote kosten ad 30. Het doelvermogen wordt dan $40+50-30=60$. In de kolom 'budget' wordt allereerst dit doelvermogen ingevoerd. Op basis van de verstrekte gegevens kan nu het grootboek als volgt worden geopend (zoals ook bij dubbel boekhouden is dit feitelijk het overschrijven van de openingsbalans): 
Tabel 7.2 Openingsbalans bij temporal triple-entry accounting.

\begin{tabular}{|c|c|c|c|c|c|}
\hline $\begin{array}{l}\text { netto activa } \\
\text { (debet) }\end{array}$ & & $\begin{array}{l}\text { eigen ver } \\
\text { (credit) }\end{array}$ & & $\begin{array}{l}\text { budget } \\
\text { (trebit) }\end{array}$ & \\
\hline Kas & 50 & Reserves & 40 & Doelvermogen & 60 \\
\hline Goederen & 50 & & & Begrote omzet & -50 \\
\hline Vreemd verm. & -60 & & & Begrote kosten & 30 \\
\hline totaal & 40 & & 40 & & 40 \\
\hline
\end{tabular}

Zoals eerder is aangegeven, wordt in de kolom 'budget' de begrote omzet als een negatief bedrag ingevoerd, respectievelijk worden de begrote kosten als een positief bedrag ingevoerd.

Wanneer vervolgens omzet wordt gerealiseerd, stel 15 per kas waarbij de afgeleverde goederen een kostprijs hebben van 10 , leidt dit tot de volgende aantekening in het journaal.

Tabel 7.3 Journaalverwerking bij temporal triple-entry accounting van een contante verkoop.

\begin{tabular}{|l|c|c|c|}
\hline & debet & credit & trebit \\
\hline netto activa (kas) & 15 & & \\
\hline $\begin{array}{l}\text { netto activa } \\
\text { (goederen) }\end{array}$ & $-1-10$ & & \\
\hline $\begin{array}{l}\text { eigen vermogen (verkoop- } \\
\text { resultaat) }\end{array}$ & & 5 & 15 \\
\hline $\begin{array}{l}\text { budget } \\
\text { (te realiseren omzet) }\end{array}$ & 5 & 5 & -10 \\
\hline $\begin{array}{l}\text { budget } \\
\text { (te realiseren kosten) }\end{array}$ & 5 & 5 \\
\hline totaal & & & 10 \\
\hline
\end{tabular}

Gebruik makend van de drie-rekeningen reeksen-theorie is deze aantekening als volgt te verklaren: 
1 Kas, zijnde een positief vermogensbestanddeel, neemt toe. Omdat hiermee het eigen vermogen toeneemt ${ }^{22}$, wordt in de debetkolom een positief bedrag ingevoerd $(+15)$.

2 Goederen, zijnde een positief vermogensbestanddeel, neemt af en hiermee neemt ook het eigen vermogen af. Hiervoor wordt in de debetkolom een negatief bedrag ingevoerd $(-/-10)$.

3 Door het verkoopresultaat, zijnde een boeking op een positieve vermogensrekening, neemt het eigen vermogen toe. Hiervoor wordt in de creditkolom een positief bedrag ingevoerd $(+5)$.

4 Doordat een deel van de begrote omzet - zijnde een boeking op een positieve budgetrekening waarvan het saldo is afgenomen - is gerealiseerd, is het eigen vermogen toegenomen (respectievelijk is de te realiseren toename van het eigen vermogen afgenomen) waarvoor in de trebitkolom een positief bedrag wordt ingevoerd $(+15)$.

5 Doordat een deel van de begrote kosten - zijnde een boeking op een negatieve budgetrekening waarvan het saldo is afgenomen - is gerealiseerd, is het eigen vermogen afgenomen (respectievelijk is de in het resterende deel van de budgetperiode te realiseren toename van het eigen vermogen toegenomen) waarvoor in de trebitkolom een negatief bedrag wordt ingevoerd $(-/-10)$.

Bij het aankopen van een nieuwe machine, stel voor 20 per kas, is de aantekening in het journaal bij temporal triple-entry accounting als volgt:

Tabel 7.4 Journaalverwerking bij temporal triple-entry accounting van de aankoop van een machine.

\begin{tabular}{|l|c|l|l|}
\hline & debet & credir & trebit \\
\hline netto activa (machines) & 20 & & \\
\hline netto activa (kas) & $-1-20$ & & \\
\hline eigen vermogen & & & \\
\hline budget & & & \\
\hline totaal & 0 & 0 & 0 \\
\hline
\end{tabular}

In dit geval zijn uitsluitend rekeningen van vermogensbestanddelen in het geding en derhalve wordt uitsluitend de debetkolom gemuteerd. Enerzijds, door de toename van de machines (positief vermogensbestanddeel), neemt het eigen vermogen toe waarvoor we een positief bedrag ingeven. Anderzijds, door de afname van de kas (positief vermogens-

\footnotetext{
${ }^{22}$ Wanneer de journaalpost

Kas

Aan Eigen vermogen
}

wordt gemaakt, komt de toename van het eigen vermogen ten gevolge van de toename van de kas vanzelf tot uitdrukking. 
bestanddeel), neemt het eigen vermogen af waarvoor we een negatief bedrag in de debetkolom ingeven.

Bij het per kas betalen van 3 voor onderhoudskosten, is de aantekening in het journaal:

Tabel 7.5 Journaalverwerking bij temporal triple-entry accounting van een betaling voor onderhoudskosten.

\begin{tabular}{|l|l|l|l|}
\hline & debet & credit & trebit \\
\hline netto activa (kas) & $-/-3$ & & \\
\hline $\begin{array}{l}\text { eigen vermogen (kos- } \\
\text { ten) }\end{array}$ & & $-/-3$ & \\
\hline $\begin{array}{l}\text { budget } \\
\text { (begrote kosten) }\end{array}$ & & & $-1-3$ \\
\hline totaal & -3 & $-1-3$ & $-/-3$ \\
\hline
\end{tabular}

Door de afname van de kas (positief vermogensbestanddeel) neemt het eigen vermogen af waarvoor we in de debetkolom een negatief bedrag ( $(-/ 3)$ ingeven. Door de betaling van onderhoudskosten (negatieve vermogensrekening) neemt het eigen vermogen af waarvoor we in de creditkolom een negatief bedrag $(-/-3)$ ingeven. Bovendien neemt door realisatie van een deel van de begrote onderhoudskosten (een negatieve budgetrekening waarvan het saldo afneemt) het eigen vermogen af respectievelijk de in het resterende deel van de budgetperiode te realiseren toename van het eigen vermogen toe waarvoor we in de trebitkolom een negatief bedrag invoeren (-/-3).

Stel dat door nieuwe beschikbare gegevens het doelvermogen wordt verhoogd met 5 , bestaande uit 10 aan omzet en 5 aan kosten. In dit geval dienen uitsluitend budgetrekeningen te worden gemuteerd. In de trebitkolom voegen we aan het doelvermogen 5 toe $(+5)$. Het saldo van de rekening 'Begrote omzet' (een positieve budgetrekening) neemt toe waarvoor we in de trebitkolom $/-10$ ingeven. Het saldo van de rekening 'Begrote kosten' (een negatieve budgetrekening) neemt eveneens toe waarvoor we in de trebitkolom +5 ingegeven. De aantekening in het journaal van de budgetrevisie is dan: 
Tabel 7.6 Journaalverwerking bij temporal triple-entry accounting van een budgetrevisie.

\begin{tabular}{|l|l|l|c|}
\hline & debet & credit & trebit \\
\hline doelvermogen & & & 5 \\
\hline $\begin{array}{l}\text { budget } \\
\text { (begrote omzet) }\end{array}$ & & & -10 \\
\hline $\begin{array}{l}\text { budget } \\
\text { (begrote kosten) }\end{array}$ & & & 5 \\
\hline totaal & $\mathbf{0}$ & $\mathbf{0}$ & $\mathbf{0}$ \\
\hline
\end{tabular}

Na verwerking van bovengenoemde vier financiële feiten ziet de (voorlopige) eindbalans er als volgt uit:

Tabel 7.7 (Voorlopige) Eindbalans bij temporal triple-entry accounting.

\begin{tabular}{|lr|ll|lr|}
\hline $\begin{array}{l}\text { netto acriva } \\
\text { (debet) }\end{array}$ & & $\begin{array}{l}\text { eigen vermogen } \\
\text { (credit) }\end{array}$ & & $\begin{array}{l}\text { budget } \\
\text { (trebit) }\end{array}$ & \\
\hline Kas & 42 & Reserves & 40 & Doelvermogen & 65 \\
\hline Goederen & 40 & Verkoopres. & 5 & Begrote omzet & -45 \\
\hline Machines & 20 & Onderhoud & -3 & Begrote kosten & 22 \\
\hline Vreemd verm. & -60 & & & & \\
\hline totaal & 42 & & 42 & & $\mathbf{4 2}$ \\
\hline
\end{tabular}

\subsubsection{Het budget, een derde dimensie?}

Tot zover lijken er weinig problemen te bestaan met temporal triple-entry accounting. Uit de aangepaste vergelijking [6] volgt dat

$$
\text { heden }=\text { toekomst }[8]
$$

Betekent deze gelijkheid dat

1) de toekomst volledig wordt verklaard uit het heden?

of

2) dat het heden volledig wordt verklaard uit de toekomst?

Het laatste is onmogelijk ${ }^{23}$ maar ook de eerste betekenis kan niet aan de bedoelde gelijkheid worden gegeven. Het heden is immers gemeten per een bepaald tijdstip en dit heeft niet de potentie iets te verklaren (explanans te zijn), maar kan hoogstens het

\footnotetext{
${ }^{23}$ Zoals ouders (heden) aan kinderen leven kunnen schenken (toekomst), is dit omgekeerd niet mogelijk.
} 
voorwerp van analyse zijn (explanandus) ${ }^{24}$. Bij temporal triple-entry accounting kan derhalve niet (dat wil zeggen: in theoretisch-wetenschappelijk opzicht) worden gesproken van drie-dimensionale accounting. Eerder is temporal triple-entry accounting het tweemaal toepassen van dubbel boekhouden: het verleden wordt simpelweg in de toekomst gespiegeld waarbij alleen het teken is veranderd. Dit laatste komt tot uitdrukking in de openingsbedragen: toekomstige opbrengsten worden negatief en toekomstige kosten worden positief geopend ${ }^{25}$. De 'spiegeling' is ook waarneembaar aan de gehanteerde boekingsregels (zie tabel 7.1): de boekingsregel voor vermogensrekeningen (rij 4 en 5) en de boekingsregel voor budgetrekeningen (rij 6 en 7) zijn in elkaar gespiegeld ${ }^{26}$. Een nieuwe dimensie zou betekenen dat de derde dimensie op een zelfde wijze aan de tweede dimensie is gerelateerd zoals de tweede dimensie aan de eerste dimensie. Dit betekent bijvoorbeeld een relatie zoals die bestaat tussen de eerste en tweede afgeleide van een variabele. In differential triple-entry accounting wordt deze gedachte nader uitgewerkt (zie paragraaf 7.5$)^{27}$. Bij temporal triple-entry accounting verhoudt de derde dimensie zich tot de eerste dimensie op precies de zelfde wijze als de tweede dimensie zich tot de eerste dimensie verhoudt. De 'spiegeling' betekent dat er geen volledig nieuwe dimensie is toegevoegd of anders gezegd: er vindt binnen temporal triple-entry accounting geen verdieping plaats. Dit uit zich in het feit dat niet of nauwelijks nieuwe grootboekrekeningen worden toegevoegd voor het administreren van de derde dimensie 'budget'. De uitbreiding van enkel boekhouden naar dubbel boekhouden betekende dat een geheel nieuwe groep rekeningen in het grootboek werd geïntroduceerd (de vermogensrekeningen). Voor een echte nieuwe derde dimensie zal een zelfde revolutionaire ontwikkeling nodig zijn. Budgetrekeningen zoals die worden gebruikt in temporal triple-entry accounting en vermogensrekeningen zijn feitelijk de zelfde rekeningen (alleen het teken is

\footnotetext{
${ }^{24}$ Feitelijk is de vergelijking 'heden=tockomst' dimensionaal heterogeen. Zie ook voetnoot 15.

25 Indien van toepassing worden toekomstige positieve vermogensbestanddelen negatief en toekomstige negatieve vernogensbestanddelen positief geopend.

${ }^{26}$ De boxkingsregels voor respectievelijk positieve en negatieve budgetrekeningen zijn omgekeerd aan de boekingsregels voor respectievelijk positieve en negatieve vermogensrekeningen. Bij de eerste twee dimensies, samenstelling en omvang van het eigen vermogen, ligt dit anders. De boekingsregels voor respectievelijk positieve en negatieve vermogensbestanddelen zijn de zelfde als die voor respectievelijk positieve en negatieve vermogensrekeningen.
}

${ }^{27} \mathrm{Bij}$ toepassing van enkel boekhouden wordt indirect, via administratie van de samenstellende delen, de omvang van het eigen vermogen gemeten. Dit kan slechts op bepaalde momenten (bij het opmaken van de balans). Bij dubbel boekhouden worden ontwikkelingen in de omvang van het eigen vermogen direct geadministreerd zodat continu de omvang van het eigen vermogen kan worden gevolgd. Men kan in dit verband stellen dat de eerste dimensie is 'omvang' en de tweede dimensie 'ontwikkelingen in de omvang'. Administratie van een derde dimensie geeft dan een beeld van de 'ontwikkelingen in de ontwikkeling van de omvang'. Hierbij gaat het om ontwikkelingen in resultaatposten. De budgetdimensie zoals die in temporal triple-entry accounting wordt geadministreerd, geeft evenwel op deze laatste ontwikkelingen geenszins zicht. 
gewijzigd). Zowel in de credit- als trebitkolom worden mutaties in de omvang van het eigen vermogen geregistreerd ${ }^{28}$.

De conclusie van het voorgaande is dat 'heden' en 'verleden' niet de gronddimensies zijn van het dubbel boekhouden en derhalve dat 'toekomst' feitelijk niet als derde dimensie kan fungeren ${ }^{29}$. Temporal triple-entry accounting is geen zuivere vorm van drie-dimensionale accounting. In temporal triple-entry accounting wordt het dubbel boekhouden twee keer toegepast: (1) op het heden en het verleden en (2) op het verleden en de toekomst. Dit betekent overigens niet dat temporal triple-entry accounting geen enkele betekenis heeft. Afhankelijk van de informatiebehoeften van de gebruikers kan een dergelijk systeem een bepaalde informatieve waarde hebben.

\subsubsection{Temporal triple-entry accounting en budgettering}

Budgetteren is een proces waarbij berekeningen worden gemaakt van de gevolgen die de uitvoering van bepaalde plannen met zich brengt. Budgetten zijn streefcijfers die tot doel hebben de bedrijfsmedewerkers te motiveren tot het realiseren van de bedrijfsdoelstellingen (Blommaert et al, 1993:11,232).

In temporal triple-entry accounting kan gebruik worden gemaakt van de in de budgettering toegepaste begrotingstechnieken. Maar tussen temporal triple-entry accounting en budgetteren bestaat toch een aantal verschillen. Niet alleen geschiedt de budgettering nog vaak extracomptabel terwijl temporal triple-entry accounting een intracomptabele activiteit is, maar ook is de budgettering functiegericht terwijl triple-entry accounting transactiegericht is. Bovendien vindt de budgettering vaak plaats op slechts enkele deelgebieden (sommige afdelingen) terwijl triple-entry accounting een totaal omvattend systeem is. Budgettering is een proces waarbij de menselijke factor (met name ten aanzien van de motivatie) van groot belang is. Het gaat bij budgetteren om het effectief en efficiënt coördineren van de over diverse personen en afdelingen verdeelde activiteiten welke nodig zijn voor het realiseren van de bedrijfsdoelstellingen. Temporal triple-entry accounting is daarentegen in hoofdzaak een technisch-administratief gebeuren, het is meer accounting dan 'control'.

Tot slot geldt dat temporal triple-entry accounting, door dat het transactiegericht is, een continu proces is. In het systeem wordt slechts dán tot een aantekening overgegaan, wanneer aan de hand van een boekingsdocument ondubbelzinnig kan worden vastgesteld

\footnotetext{
${ }^{28}$ Het is immers per definitie zo dat wanneer de huidige omvang van het eigen vermogen muteert, bijvoorbeeld door kosten en/of opbrengsten, ook de begrote (tocname van de) omvang van het eigen vermogen verandert.

${ }^{29}$ De onmogelijkheid om het temporal triple-entry accountingsysteem op cen logische en consistente wijze uit te breiden naar een vierdimensionaal systeem, bevestigt de wankelijke theoretische basis van dit systecm.
} 
dat een budgetrekening dient te worden gemuteerd. Er dient derhalve een reële transactie of gebeurtenis te hebben plaatsgevonden. Budgettering is de (subjectieve) inschatting van de toekomstige geldelijke effecten van verwachte (trans)acties en/of bepaalde gebeurtenissen. Het inschatten van deze effecten casu quo het bijstellen van de verwachtingen hieromtrent vindt in de praktijk meestal op gezette tijden en derhalve discontinu plaats ${ }^{30}$.

In tabel 7.8 zijn de verschillen tussen temporal triple-entry accounting en budgettering nog eens samengevat.

Tabel 7.8 Temporal triple-entry accounting versus budgettering.

\begin{tabular}{|l|l|}
\hline temporal triple-entry accounting & budgettering \\
\hline intracomptabel & (vaak) extracomptabel \\
\hline totaalsysteem & $\begin{array}{l}\text { (vaak) op deel- } \\
\text { activiteiten toegepast }\end{array}$ \\
\hline transactiegericht & functiegericht \\
\hline $\begin{array}{l}\text { administratief-technisch } \\
\text { (accounting) }\end{array}$ & $\begin{array}{l}\text { mens-geörienteerd } \\
\text { ('control') }\end{array}$ \\
\hline $\begin{array}{l}\text { continu proces, } \\
\text { op basis van reële transacties }\end{array}$ & $\begin{array}{l}\text { discontinu proces, } \\
\text { op basis van begrote } \\
\text { transacties }\end{array}$ \\
\hline
\end{tabular}

\subsection{Differential triple-entry en momentum accounting}

\subsubsection{De dimensies in differential triple-entry accounting}

Netto-activa zijn tijdstipgrootheden of voorraadgrootheden. Netto-activa worden geadministreerd op rekeningen van vermogensbestanddelen. Deze rekeningen geven de samenstelling weer van het eigen vermogen (bezittingen en schulden) per een bepaald moment in het heden. Daarentegen zijn vermogensrekeningen, de rekeningen waarop ontwikkelingen in de omvang van het eigen vermogen worden geadministreerd, tijdvakgrootheden of stroomgrootheden. Deze beschrijven hoe het eigen vermogen in het verleden is opgebouwd. Vergelijking [4] 'netto activa=eigen vermogen' en vergelijking [5] 'heden=verleden' kunnen dan ook als volgt worden geschreven:

$\triangle$ voorraad $=$ stroom [9]

\footnotetext{
30) 'Revolving budgeting' is cen voorbeeld van een vorm van budgetteren waarbij cok de budgetten regelmatig worden bijgesteld.
} 
Deze verbinding tussen voorraadgrootheden en stroomgrootheden is de essentiële karakteristiek van het dubbel boekhouden (Ijiri, 1986:746; 1989:43). 'Stroming' betekent een verandering in voorraad zoals die tussen twee momenten is vast te stellen. Wanneer de voorraad continu zou veranderen, ontstaat een stroming waarvan de intensiteit (snelheid) op enig moment kan worden gemeten als de (wiskundig) eerste afgeleide ${ }^{30}$. In accounting-opzicht is dit de winstcapaciteit zoals die per een bepaald tijdstip bestaat, de winstsnelheid of 'income momentum'. Bij een winstsnelheid van '300 per maand' is de winst na een maand in principe 300.

\section{Wanneer}

1) in het enkel boekhouden (in principe uitsluitend) hoeveelheden voorraad worden geadministreerd en

2) in het dubbel boekhouden naast voorraad- ook stroomgrootheden (kosten en opbrengsten) worden geadministreerd en

3) een voorraad overgaat in een stroming (wanneer de voorraad continu verandert) waarvan de intensiteit kan worden gemeten door de eerste afgeleide ervan te bepalen, komt de vraag aan de orde: Bestaat er in dit verband ook een tweede afgeleide en wat is hiervan de betekenis?

In de wis- en natuurkunde werkt men al sinds Newton met eerste en tweede afgeleiden, zijnde manieren om stroming tussen twee punten te beschrijven. Maar wat zou een afgeleide van de winstsnelheid betekenen?

De afgeleide van de winstsnelheid kwantificeert veranderingen in de winstsnelheid, genoemd impulsen. Deze impliceren veranderingen in resultaatposten welke tot stand komen onder invloed van winstkrachten. Wanneer de invloed van een winstkracht wordt uitgedrukt als een verandering in de winstsnelheid, is sprake van een 'groeikracht', 'accelerator' of 'force'. Bij een 'groeikracht' van '50 per maand' is de winstsnelheid na een maand in principe met 50 toegenomen. Uitgaande van een winstsnelheid per het begin van de eerste maand van 300 , is de winstsnelheid per het eind van de eerste maand derhalve 350 en per het eind van de tweede maand 400 . In de eerste maand is de gemiddelde winstsnelheid 325 . Wanneer deze winstsnelheid inderdaad wordt gerealiseerd, is de winst in de eerste maand 325. De gemiddelde snelheid in de tweede maand is 375 welke bij realisatie leidt tot een winst in deze maand van 375 . Aldus geeft de groeikracht een volledige verklaring voor de mutatie in de winst, dit is de ontwikkeling in de ontwikkeling van de omvang van het eigen vermogen.

Het concept waarbij veranderingen in resultaatposten worden geanalyseerd, bestaat reeds in de management accounting: de verschillenanalyse. Maar, deze verschillenanalyse wordt

\footnotetext{
${ }^{30}$ Dit is voor accountingdoeleinden steeds een tijdafgeleide. De eerste afgeleide geeft dan aan hoe de afhankelijke variabele (de winst) verandert wanneer de factor tijd met 1 toencemt.
} 
meestal slechts op bepaalde items en extracomptabel uitgevoerd ${ }^{31}$. De verschillenanalyse maakt derhalve geen integrerend onderdeel uit van het bestaande administratieve systeem. Bovendien worden in geval van differential triple-entry accounting de verschillen geadministreerd op het moment dat de oorzaken ervan (winstkrachten) zich manifesteren. $\mathrm{Bij}$ de conventionele verschillenanalyse wordt ex post gezocht naar een verklaring voor de geconstateerde verschillen. Aldus treedt er een time-lag op in de gegevensverwerking en informatievoorziening.

Aan een bepaalde mate van verandering, rekening houdend met de periode waarin deze verandering heeft plaatsgevonden, kan in de accounting een eenduidige betekenis worden toegekend. Zoals we gezien hebben, is de vermenigvuldiging van de factor 'tijd' en 'winstsnelheid van het eigen vermogen' gelijk aan de winst over de in ogenschouw genomen periode. Een winstsnelheid van ' 300 per maand' geeft over een jaar een winst van $300 \times 12=3.600$ (de tijd-integraal). De berekening veronderstelt een constante winstsnelheid.

Een 'force' van ' 15 per maand per maand' geeft over een jaar een toename van de winstsnelheid met $15 \times 12=180$. Bij een aanvangswinstsnelheid van 300 is de winstsnelheid per het einde van het jaar 480. De gemiddelde winstsnelheid over het jaar is in dit geval $\{(300+480) / 2=\} 390$ per maand en bij realisatie hiervan is de winst over het betreffende jaar 12 × 390=4.680. In vergelijking met de situatie van constante winstsnelheid levert dit een winstdifferentie op van $(4.680-3.600=1.080)$. Deze differentie, een verandering in de verandering van de omvang van het eigen vermogen ${ }^{32}$, kan volledig worden verklaard door het verschil in gemiddelde winstsnelheid in beide situaties: $12 \mathrm{x}$ $(390-300=) 1.080$. Ijiri noemt het administratieve systeem waarin dergelijke differenties kunnen worden verantwoord 'differential triple-entry accounting ${ }^{33}$.

Voordat we het systeem van differential triple-entry accounting verder zullen uitwerken, is het zinvol kort terug te zien op een aantal belangrijke ontwikkelingen dat zich in de geschiedenis van de natuurkunde heeft voorgedaan. Het eerste gedrukte boek over dubbel boekhouden is van Pacioli en dateert uit 1494. Derhalve heeft Pacioli geen gebruik kunnen maken van de inzichten van bijvoorbeeld Galilei en Newton. Dit zou kunnen

\footnotetext{
${ }^{31}$ Een aantal verschillenanalyses wordt intracomptabel uitgevoerd. In dit verband zijn bekend de Z-figuren en dubbele Z-figuren.
}

${ }^{32}$ Men kan hier stellen dat 'de groei van het eigen vermogen groeit' en aldus is een groeifactor ('force') aanwezig. Met name in de algemene economie is men gewend aan dergelijke 'versnellingsmechanismen' (zo spreekt men over 'de groeivoet van de bevolking').

${ }^{33}$ Een soortgelijk vraagstuk als hiervoor is geschetst, doet zich voor bij het informeren over de ontwikkeling van een schaatswedstrijd. Men informeert over 1) de totaaltijd (als tussentijd), 2) de verandering in de totaaltijd zijnde de rondetijd (een differentie van le orde) en over de verandering in de rondetijd (een differentie van de tweede orde). Gegevens over verandering in rondetijden zijn vaak het meest informatief bij het beoordelen van de mogelijke eindtijd. In deze vergelijking is de totaaltijd als tussentijd de actuele omvang van het eigen vermogen, de rondetijd de periodewinst en de verandering in de rondetijd de verandering in de winst per periode. 
impliceren dat het model van Pacioli is gebaseerd op het wereldbeeld van Aristoteles ${ }^{34}$. In wetenschappelijk opzicht is het in elk geval interessant na te gaan hoe het accountingmodel er zou uitzien indien rekening wordt gehouden met de modeme natuurkundige inzichten. De natuurkunde bestudeert immers van oudsher bewegingen van voorwerpen. Inzicht in de hierbij toegepaste procedures kan van belang zijn voor de accounting omdat feitelijk ook de accounting beweging in de zin van processen beschrijft.

\subsubsection{Beschrijving van beweging en kracht in de natuurkunde en de implica- ties voor de accounting; inleiding}

Een bedrijf kan men bezien als een object dat op weg is naar een bepaald doel. Dit doel kan worden uitgelegd als een bepaalde mate van winstgevendheid, een bepaald marktaandeel, een bepaald omzetniveau, enzovoort. In de accounting beschrijven we feitelijk de periodieke beweging ('afgelegde weg') van het bedrijf op weg naar de realisatie van deze doelstelling(en).

In de natuurkunde onderzoekt men bewegingen (of de rust) van stoffelijke lichamen en de oorzaken van deze bewegingen (of die rust) in de theoretische mechanica. Binnen de theoretische mechanica worden onderscheiden:

1) de kinematica of bewegingsleer, waarin de bewegingen worden geanalyseerd zonder de oorzaken hiervan te onderzoeken;

2) de dynamica of krachtenleer. De dynamica wordt ingedeeld in (1) de statica of evenwichtsleer en (2) de kinetica waarbinnen de bewegingen in verband met hun oorzaken worden bestudeerd.

Als zodanig bestaat er voor wat met name de klassieke mechanica betreft 'van nature' een bepaalde mate van overeenkomst tussen de natuurkunde en de accounting ${ }^{35}$. Door

\footnotetext{
${ }^{34}$ Voor deze veronderstelling is geen bewijs geleverd. Pacioli's uiteenzetting over dubbel boekhouden is echter tevens een beschrijving van de geest van zijn tijd, zoals debet en credit kunnen worden verklaard uit het vermijden van negatieve getallen. Ten Have merkt in dit verband op: "Zo zijn er vele vragen, die slechts beantwoord kunnen worden, indien de geest van de tijd mede in de verklaring wordt betrokken" (ten Have, 1973:12). Het ligt derhalve niet voor de hand dat Pacioli een ander dan het toen heersende beeld van Aristoteles over hemelse en aardse bewegingen, (bewust dan wel onbewust) heeft toegepast in 'zijn' dubbel boekhoudmodel.

Overigens verwijst Pacioli wel naar Aristoteles als hij hem in hoofdstuk 1, wanneer Pacioli de 'restanten' beschrijft van dingen die veranderen, 'de filosoof' noemt. Het gaat hierbij om het concept van kapitaalhandhaving (HernandezEsteve, 1993:12).

${ }^{35}$ Misschien is het in dit verband dan ook niet verwonderlijk dat Tinbergen, de in het buitenland zo veelvuldig geciteerde Nederlandse econoom en Nobelprijswinnaar, in cerste instantie fysica (aan de Universiteit van Leiden bij Ehrenfest) en niét economie had gestudeerd. Tinbergen is vooral bekend geworden als de grondlegger van het stelsel van nationale rekeningen (welke feitelijk ook bewegingen of 'stromen' beschrijven).
} 
in de historie van de klassieke mechanica te duiken, komen deze parallellen aan het licht. De van toepassing zijnde accounting-implicaties zullen op de plaatsen waar dat het meest logisch is, aan de orde worden gesteld.

\subsubsection{Enkele hoofdlijnen van de ontwikkelingen in de klassieke mechanica $^{36}$}

Volgens Aristoteles (384-322 voor Chr.), leerling van Plato, stond de aarde in het centrum van het heelal. De planeten bewogen in harmonische cirkels rond de aarde. Deze bewegingen waren vergelijkbaar met het inwendige van een klok: gestaag en voorspelbaar. Bewegingen van voorwerpen ontstonden omdat en totdat er een kracht op werd uitgeoefend. Derhalve was de aanwezigheid van een kracht ('force') voorwaarde voor beweging. De vier fundamentele elementen van de natuur (vuur, lucht, water en aarde) hadden alle een natuurlijke plaats ${ }^{37}$. Wanneer een element zich op zijn natuurlijke plaats bevond, bleef het in rust. In het andere geval had het element de neiging ('potentia') naar zijn natuurlijke plaats terug te keren. Tot ver in de middeleeuwen hield het beeld van Aristoteles stand.

Volgens Copernicus (1473-1543) was de zon het middelpunt van het heelal. De aarde en alle overige planeten bewogen in cirkels om de zon heen ${ }^{38}$.

Kepler (1571-1630) bouwde voort op de ideeën van Copernicus $^{39}$. Na vele waarnemingen en eindeloze wiskundige berekeningen kwam Kepler tot de conclusie dat de bewegingen van planeten in eenvoudige mathematische termen konden worden beschreven. Volgens Kepler bewogen de planeten zich in ellipsvormige banen rond de zon. Met Kepler is er een scheiding ontstaan tussen natuurkunde, religie en menswetenschappen (Scholtes, 1991:59). Voor het verklaren van de verschijnselen werd God ineens overbodig.

\footnotetext{
${ }^{36}$ Ijiri verwijst slechts sporadisch naar de mogelijke invloed van ontwikkelingen in de natuurkunde op een herconceptualisering van de accounting (1982:20-21). Voor een goed begrip van de (on)mogelijkheden hierbij is evenwel een verdere gerichte verdieping in de natuurkunde mijns inziens van groot belang.

${ }^{37}$ De laagste plaats was voor de aarde, net daarboven hoorde het water thuis, daarboven (omdat deze lichter was) lucht. Vuur, waarvan de vlammende tongen door de lucht konden schieten, bezette de hoogste plaats.

${ }^{38}$ Deze stelling van Copernicus kon in religieuze kringen, waar de perfectie van de schepping inhield dat de aarde het middelpunt van de natuur moest zijn, niet worden venteerd. Het werk van Copernicus is daarom lange tijd genegeerd. Voor zijn ketterse stelling werd Copernicus evenwel niet, zoals zijn voorganger Giardo Bruno, naar de brandstapel gevoerd.
}

${ }^{39}$ Kepler was een leerling van de beroemde Deense sterrenkundige Tycho Brahe (1546-1601) die een soort tussenstandpunt had ingenomen ten aanzien van Aristoteles en Copernicus. Brahe is vooral bekend geworden als constructeur van sterrenkundige instrumenten. Kepler heeft hiermee uiteindelijk zijn befaamde wetten kunnen afleiden. 
Galilei (1564-1642) richtte als eerste een telescoop op het heelal. Hij ontdekte de manen van Jupiter die rond Jupiter draaiden. Hiermee stond onomstotelijk vast dat het niet de aarde kon zijn die het middelpunt vormde van alle bewegingen van de hemellichamen. Het beeld van Aristoteles werd definitief verworpen en de wetenschap van de mechanica ontwikkelde zich. Het zoekproces naar een allesomvattende verklaring voor de natuurverschijnselen die zich voordeden, kreeg hiermee een andere wending. Galilei stelde dat de afstand (valbeweging) over opeenvolgende gelijke tijdsintervallen evenredig zou zijn met de oneven getallen, dat wil zeggen, na 1 tijdsinterval is 1 afstandseenheid afgelegd, in het 2e tijdsinterval worden 3 afstandseenheden afgelegd (cumulatief 4 ), in het $3 \mathrm{e}$ tijdsinterval worden 5 afstandseenheden afgelegd (cumulatief 9), enzovoort. Berekend vanaf het vertrekpunt bedraagt de gemiddelde snelheid, gemeten als de afgelegde afstand gedeeld door het aantal tijdsintervallen (verstreken tijd), respectievelijk $0,1,2,3$, enzovoort. Galilei reageerde hiermee op een beschrijving van de (val)beweging door Leonardo Da Vinci (1452-1519), vriend van Lucas Pacioli. Da Vinci stelde dat de gemiddelde snelheid berekend vanaf het vertrekpunt zou verlopen als $0,1,1 \frac{1}{2}, 2,2 \frac{1}{2}, 3$, enzovoort. De empirie heeft aangetoond dat de beschrijving volgens $\mathrm{Da}$ Vinci onjuist is en Galilei de valbeweging op correcte wijze heeft weergegeven ${ }^{40}$. Wanneer de afgelegde weg (afstand) wordt weergeven door $w$ en de tijd door $t$, dan geldt: $w(t)$. Dit betekent dat de afgelegde weg een functie is van de verstreken tijd. Wanneer we het verband tussen afgelegde weg en tijd zoals door Galilei opgesteld en in een formule weergeven, krijgen we:

$$
w(t)=c t^{2} \quad[10]
$$

Wanneer $t=1$ geldt dat $w(1)=c$. Derhalve stelt $c$ voor de numerieke waarde van de afgelegde afstand na één seconde val. De seconde is de standaardeenheid waarin de tijd wordt gemeten.

De gemiddelde snelheid $\overline{\mathrm{v}}$ in het tijdsinterval t'-t kan nu als volgt worden bepaald:

$$
\bar{v}=\frac{w(t)-w(t)}{i-t}
$$

De snelheid op een zeker tijdstip kan worden bepaald door het tijdsinterval naar 0 te laten naderen. $\mathrm{Na}$ een hele korte tijd die we $h$ noemen, bedraagt de afgelegde weg:

$$
\begin{aligned}
& w(t+h)=c(t+h)^{2} \\
& w(t+h)=c\left(t^{2}+2 t h+h^{2}\right)
\end{aligned}
$$

\footnotetext{
${ }^{40} \mathrm{Da}$ Vinci's beschrijving van de valbeweging was weer een reactie op beschrijvingen van cinder meer Albert van Saxony en Nicole Oresme. Van Suxony veronderstelde een rechtevenredig verband tussen afgelegde afstand en snelheid terwijl Oresme een rechtevenredig verband veronderstelde tussen tijd en snelheid.
} 
Aldus bedraagt de gemiddelde snelheid in het tijdsinterval $h$ :

$$
\bar{v}=\frac{w(t+h)-w(t)}{h}
$$

Dit kan worden herschreven als:

$$
\bar{v}=\frac{c\left(t^{2}+2 t h+h^{2}\right)-c t^{2}}{h}=\frac{2 c t h+c h^{2}}{h}=2 c t+c h
$$

Wanneer $h$ nadert tot nul, geldt:

$$
\overline{\mathrm{v}}=2 \mathrm{ct}
$$

Anders gezegd: de snelheid op tijdstip $\mathrm{t}$ is gelijk aan de eerste (tijds)afgeleide van de afgelegde weg:

$$
d(w)
$$

$d(t)$

Wanneer we de formule voor de afgelegde weg differentiëren naar de tijd, krijgen we:

$$
\frac{d\left(c^{2}\right)}{d(t)}=2 c t .
$$

Zoals hiervoor afgeleid, is dit de snelheid op tijdstip $t$.

De verandering in de afstand (of positie) is een snelheid, de verandering in de snelheid is een versnelling of acceleratie.

De versnelling op een bepaald tijdstip kan analoog aan de snelheid worden bepaald door de tweede tijdsafgeleide te bepalen van de afgelegde afstand dan wel de eerste afgeleide van de snelheid:

$$
\frac{d(2 c t)}{d(t)}=2 c
$$


Omdat $t$ hierin niet meer voorkomt is dit tevens de snelheid op enig tijdstip. Bovendien is $c$ een constante. Dit is een belangrijke wet bij vallende objecten: alle objecten vallen met de zelfde continue constante versnelling. Wanneer we als eenheid van tijd de seconde kiezen en als eenheid van afstand de meter, dan is de eenheid van snelheid de 'meter per seconde'. De eenheid voor de versnelling is in dit geval de 'meter per seconde per seconde', ofte wel de 'meter per seconde ${ }^{2}$.

De differentiaalvergelijking is voor het eerst door Newton toegepast en door Einstein bestempeld als misschien de grootste vooruitgang in het denken die ooit een enkel mens was vergund om tot stand te brengen. Differentiëren staat tegenover integreren, derhalve kan de afgelegde afstand worden gevonden door integratie van de snelheid casu quo de snelheid door integratie van de versnelling over het betreffende tijdsinterval.

Snelheid is feitelijk een vectorgrootheid, dat wil zeggen, de beschrijving van het object bestaat uit zijn grootte en zijn richting (vergelijk een pijl). Vectoren kennen geen vaste positie in de ruimte. In een accounting-perspectief zou een vectorbeschrijving bijvoorbeeld kunnen betekenen dat van de winst van een onderneming behalve het getal (de grootte) ook de mate wordt aangegeven waarin verandering is gekomen in de winstpositie. Stel dat bedrijf A een jaarwinst heeft van 100 en bedrijf B een jaarwinst van 120 terwijl bedrijf $A$ bij het opmaken van de jaarstukken op een winstniveau zit van 15 per maand en bedrijf B van 10 per maand. Het is dan, ceteris paribus, duidelijk dat bedrijf A in de toekomst financieel beter zal gaan presteren dan bedrijf $B$. De winstaanduidingen in vectorgrootheden voor bedrijf A respectievelijk bedrijf B zijn in dit geval (100, $15 /$ maand) en (120,10/maand). Kennelijk heeft bedrijf $A$ de winstcapaciteit van 15 per maand niet geheel in het betreffende boekjaar kunnen realiseren.

Het is Newton (1643-1727) geweest die een geniale synthese tot stand bracht tussen de wetmatigheden van aardse en hemelse verschijnselen. Galilei beschreef de bewegingen sec terwijl het Newton meer te doen was om de oorzaken van de bewegingen. Newton gebruikte voor het beschrijven van de beweging van een voorwerp een drievoudig concept:

(1) plaats ('position'),

(2) snelheid ('velocity'), zijnde de verandering in plaats en

(3) versnelling ('acceleration'), zijnde de verandering in snelheid.

Snelheid respectievelijk versnelling tezamen met de massa van een object ${ }^{41}$, bepalen wat Ijiri noemt 'momentum' respectievelijk 'force'. Momentum is het produkt van massa en snelheid. Force (kracht) is het produkt van massa en versnelling.

\footnotetext{
${ }^{41}$ Massa kan men gelijk stellen aan gewicht, mits op de zelfde plaats op aarde vastgesteld. In accountingtermen is massa de omvang van het (eigen) vermogen.
} 
Momentum $=$ massa $\times$ snelheid $^{42}[13]$

Force $=$ massa $\times$ versnelling $[14]$

In accountingoptiek is 'momentum' gerelateerd aan 'winst' (of in het algemeen 'bedrijfsresultaat'). Men zou momentum kunnen vertalen met inertie (traagheid). Dit is de eigenschap van lichamen om te volharden in de toestand van rust of beweging waarin ze zich bevinden. Het winstbedrag beschrijft evenwel het absolute bedrag waarmee het eigen vermogen van een onderneming in een bepaalde periode is gemuteerd. Het is de gemiddelde snelheid waarmee het geld is verdiend, het is immers 'afgelegde weg' (=vermogensmutatie) gerelateerd aan 'tijd' ${ }^{43}$. De resultatenrekening is feitelijk een overzicht van de realisatie van deze snelheid.

Alhoewel gerelateerd aan winst is 'momentum' niet het zelfde als winst. Momentum is 'winstsnelheid', dat wil zeggen: de winstcapaciteit uitgedrukt in een bepaalde tijdseenheid. De 'income momentum' is bijvoorbeeld ' 20 gulden per maand' of ' 300 gulden per jaar'. Bij een gelijkblijvend momentum is de winst gelijk aan het produkt van momentum en tijd: bij een onveranderde winstcapaciteit van 20 gulden per maand, bedraagt de winst over een jaar $20 \times 12=240$. In het algemeen geldt derhalve:

$$
\text { Winst }=\text { momentum } \times \text { tijd }^{44}[15]
$$

De aard van de posten op een 'momentum statement', dit is een overzicht van de samenstelling van de 'income momentum' per een bepaald moment, is de zelfde als die van een resultatenrekening. Alleen de periode waarin de posten zijn uitgedrukt is anders. Op een resultatenrekening staan de posten uitgedrukt in guldens over een bepaalde periode (stroomgrootheden), op een 'momentum statement' staan de posten in guldens per een bepaalde periode (tijdstipgrootheden). Het bedrijfsresultaat is de integraal van momentum en tijd gedurende welke zich dit momentum heeft kunnen uitspannen.

\footnotetext{
${ }^{42}$ Fysici gebruiken bijna nooit het begrip 'snelheid' on de bewegingstoestand van een deeltje te beschrijven, maar eerder een grootheid die 'impuls' wordt genoemd en die is gedefinieerd als massa van het deeltje maal zijn snelheid.

${ }^{43}$ In traditionele accountingsystemen is 'snelheid' geen onbekende, denk aan de omloopsnelheid van het totale vermogen. Overigens dient de vergelijking 'momentum=massa*snelheid' te worden geïnterpreteerd als 'absolute snelheid=massa*relatieve snelheid'. De massa kan worden gezien als het totale bedrag dat is geinvesteerd in de netto activa, zeg 5000. De relatieve snelheid waarmee geld wordt verdiend is bijvoorbeeld $2 \%$ per maand (het rendement). Dit levert een absolute snelheid op waarmee het geld wordt verdiend (= income momentum) van 100 per maand.

${ }^{44}$ Feitelijk is elke vorm van 'accounting measurement' een functie van de tijd en worden accountinggegevens als tijdreeksen gepresenteerd. Over het werk van ljiri op het terrein van "accounting measurement" merkt Mattessich op: "..., from the point of view of theory construction, his work is one of the most impressive contemporary accounting theories" (Mattessich, 1980:165).
} 
Het winstcijfer van een bedrijf is een stroomgrootheid (het resultaat is gemeten over een bepaalde periode). De winstsnelheid of income momentum (zie vergelijking [13]) is een voorraadgrootheid en wordt uitgedrukt als winst per periode, bijvoorbeeld per maand of per jaar. Force of groeikracht, gerelateerd aan versnelling zoals vergelijking [14] toont, wordt uitgedrukt in guldens per periode per periode. Dit is per periode ${ }^{2}$. Een (positieve) groeikracht van 10 per maand per maand betekent dat de winstsnelheid elke maand met 10 toeneemt (constante versnelling) en derhalve de rekenkundige reeks vormt van 10, 20 , 30,40 , enzovoort.

In de traditionele berichtgeving wordt impliciet verondersteld dat de snelheid waarmee de ondememing geld verdient, in de tijd niet of nauwelijks wijzigt. Dat wil zeggen: over eventuele veranderingen in de winstsnelheid wordt niet (volledig noch systematisch) gerapporteerd. Echter, wanneer de winst niet met een constante snelheid wordt verdiend (anders gezegd: niet constant met de gemiddelde snelheid wordt gerealiseerd) en daarover geen verslag wordt gedaan, kan dit vergaande gevolgen hebben voor bijvoorbeeld een winstvoorspelling of een bedrijfsbeoordeling. Vergelijk in dit verband twee bedrijven waarbij het ene bedrijf $A$ is gestart met een winstsnelheid van 2 per maand en het andere bedrijf $\mathrm{B}$ met een winstsnelheid van 3 per maand. Bij bedrijf $\mathrm{B}$ is de winstsnelheid halverwege het jaar ingezakt tot 1 per maand. Wanneer deze winstsnelheden direct en volledig worden gerealiseerd, is voor bedrijf A de jaarwinst $12 \times 2=24$ en voor bedrijf $B$ $6 \times 3+6 \times 1=24$. Het feit dat bedrijf A er in dit geval beter voorstaat, komt niét tot uitdrukking in de gerealiseerde jaarwinst.

In de eerste bewegingswet van Newton (='wet van traagheid' van Galilei) wordt gesteld dat voorwerpen hun lineaire beweging met een constante snelheid voortzetten, tenzij een externe kracht dit proces (positief dan wel negatief) beïnvloedt. In deze benadering is er derhalve ook beweging mogelijk zonder een continu-kracht, dat wil zeggen: wanneer een kracht een voorwerp in beweging heeft gezet, blijft het voorwerp verder bewegen ook al verdwijnt de initiërende kracht. Er is sprake van momentum. In de (statische) benadering van Aristoteles was dit onmogelijk. Immers Aristoteles veronderstelde dat voorwerpen de neiging hadden om tot stilstand te komen na het verdwijnen van de initiërende kracht. Wanneer we de zienswijze van Newton 'vertalen' naar accounting, dan betekent dit dat bedrijven niet altijd in de zelfde mate inspanningen hoeven te verrichten teneinde opbrengsten te genereren. Ook vele kosten zullen als het ware automatisch terugkeren. In traditionele accountingsystemen beschouwen we evenwel elke transactie als zijnde nietterugkerend en dus uniek ${ }^{45}$. Gevolg is dat we iedere transactie afzonderlijk registreren. Huurbetalingen worden bijvoorbeeld elke maand geadministreerd. Wanneer we evenwel het structurele en dus repeterende karakter van deze betalingen onderkennen, zijn de beta-

\footnotetext{
${ }^{45}$ Enkele uizzonderingen daar gelaten, zoals het vormen van cen voorziening voor dubieuze debiteuren.
} 
lingen als zodanig minder interessant en komt het accent te liggen op het moment dat de basis wordt gelegd voor deze betalingen. Dit is het geval van het afsluiten van het huurcontract. Het ondertekenen van het huurcontract heeft behalve juridische ook financiële gevolgen. Vanaf dat moment wijzigt ondubbelzinnig de financiële positie van de onderneming, maar desalniettemin wordt op dat moment in de traditionele accounting (meestal) geen aantekening gemaakt van deze financiële gevolgen. Het heeft er de schijn van dat in de traditionele berichtgeving de juridische gevolgen prevaleren boven de economische ${ }^{46}$. Wanneer we de ideeën van Galilei en Newton over bewegingen toepassen in de accounting, betekent dit dat herhaling van transacties regel is en geen uitzondering. Anders gezegd: het statische klassieke accountingmodel dient te worden vervangen door een meer dynamisch model ${ }^{47}$. Ijiri heeft dit uitgewerkt in zijn 'income momentum'-concept.

De tweede bewegingswet van Newton stelt dat de kracht (F) die nodig is om een zekere versnelling (a) te bereiken, rechtevenredig is met de massa $(\mathrm{m})$ van het betreffende voorwerp:

$$
\mathbf{F}=\mathbf{m} \times \mathbf{a}[16]
$$

Vergelijking [16] kan ook worden geschreven als:

$$
\Sigma \mathrm{F} \times \Delta \mathrm{t}=\Sigma \mathrm{m} \times \mathrm{a} \times \Delta \mathrm{t}=\mathrm{m} \Sigma \mathrm{a} \times \Delta \mathrm{t}[17]
$$

$\Sigma \mathrm{a} \times \Delta \mathrm{t}$ is de snelheidsverandering die zich in het (zeer kleine) tijdvak $\mathrm{t}$ heeft voorgedaan. Deze snelheidsverandering kan ook worden geschreven als $\bar{v}_{2}-\bar{v}_{1}$ (de verandering in de gemiddelde snelheid). De vector $\Sigma \mathrm{F} \times \Delta \mathrm{t}$ wordt impuls genoemd. Impuls is de snelheidsverandering ten gevolge van een bepaalde grocikracht, geïntegreerd over de periode waarin zich deze heeft voorgedaan.

Het model van Newton is het dominante model in de wetenschap van de $19 \mathrm{e}$ eeuw geweest. In de (bedrijfs)economie is dit model toegepast door onder andere Jevons (18521882). Via de differentiaalvergelijking van Newton heeft Jevons een verklaring trachten te geven voor veranderingen in de vraag naar bepaalde goederen. Hiertoe ontwikkelde hij

\footnotetext{
${ }^{46}$ In dit opzicht is het hierna te bespreken momentum accountingsysteem te zien als een toepassing van het 'substance over form'-beginsel.

${ }^{47}$ Ook in de algemene economie ging men in eerste instantie uit van relaticf statische modellen. Voor Tinbergen was dit onder andere aanleiding het conjunctuumodel van Walras (pionier van de wiskundige economie) ter discussie te stellen. Volgens Tinbergen was dit model te statisch terwijl een moderne economic deze 'rust' niet toont.
} 
nutsfuncties met positief maar afnemend grensnut (Chatfield, 1977:177; Samuelson, 1983:787).

Na Galilei en Newton heeft de natuurkunde zich verder ontwikkeld. Als de twee belangrijkste nieuwe peilers van de moderne fysica kunnen worden gezien de relativiteitstheorie en de quantummechanica (de theorie van de atomaire verschijnselen).

De bewegingswetten van Galilei en Newton hingen af van de aanname dat er zoiets bestond als absolute beweging, dat wil zeggen: beweging ten opzichte van iets dat in rust is en onveranderlijk. Bovendien waren deze wetten alleen geldig voor relatief lage snelheden in vergelijking met de snelheid van het licht. Veranderingen (bewegingen) werden beschreven in termen van een aparte dimensie: de tijd. Door de ontdekking van elektrische en magnetische verschijnselen door met name Faraday kwam men erachter dat in zekere toestanden van de ruimte, krachtvelden genoemd, bepaalde krachten kunnen worden voortgebracht. Dit bracht Einstein in 1915 tot zijn relativiteitstheorie. In deze theorie worden absolute ruimte en absolute tijd opgeheven. Zowel ruimte als tijd worden gereduceerd tot onderdelen van de taal die een bepaalde waarnemer gebruikt om de verschijnselen te beschrijven. Ruimte is niet driedimensionaal en de tijd is geen afzonderlijke entiteit. Ruimte en tijd zijn nauw met elkaar verbonden en vormen een vierdimensionaal continuüm, 'ruimte-tijd'. Volgens de theorie van Einstein heeft de zwaartekracht de 'kromming' van ruimte en tijd tot gevolg. In verschillende gebieden van de ruimte loopt de tijd in verschillend tempo. Het begrip 'lege' ruimte had zijn betekenis verloren en de Euklidische meetkunde moest worden verlaten ${ }^{48}$. Door deze wijzigingen moest het hele kader dat werd gebruikt om de natuur te beschouwen, worden bijgesteld. Direct gevolg hiervan was de zienswijze dat massa een vorm van energie kan worden. Zelfs bij een onbeweeglijk voorwerp is er energie in zijn massa opgeslagen ${ }^{49}$. En energie is een dynamische grootheid die met activiteit en processen te maken heeft.

In de quantummechanica, waarvan Bohr de grondlegger is, probeert men het (wiskundige) werk van Newton toe te passen op het gedrag van moleculen, atomen en elektronen. Kenmerkend hierbij zijn de fundamentele onzekerheden die optreden waardoor het werken met benaderingen noodzakelijk wordt ${ }^{50}$. Je kunt of de snelheid of de positie van een deeltje berekenen, maar niet tegelijkertijd beide. Quantummechanica betekent derhalve

\footnotetext{
${ }^{48}$ Centraal in de relativiteitscheorie staat de ontdekking dat meetkunde cen schepping van het intellect is, cen construct dus. Plato bijvoorbeeld zag dat in zijn tijd geheel anders. De meetkunde werd door hem beschouwd als de volmaakte combinatie van logica en schoonheid. Vandaar ook de uitspraak van Plato: 'God is cen moetkundige'. Ook ruimte is nicts anders dan een manier van begripsvorming, zonder daarbij een werkelijk eigen bestaan te kennen.

${ }^{49}$ Dit leidde tot de beroemde vergelijking $E=\mathrm{m}^{*} \mathrm{c}^{2}$ waarin $c$ de snelheid van het licht voorstelt, in casu $300.000 \mathrm{~km}$ per seconde.

${ }^{50}$ Dit geldt met name ten aanzien van een elektron dat zich niet alleen voordoet als een declje (korrel), maar zich afhankelijk van de manier waarop je ernaar kijkt - ook als een golf kan manifesteren.
} 
het afwijzen van het objectief-deterministische model van Newton ${ }^{51}$. Men werd zich ervan bewust dat er geen onafhankelijke werkelijkheid bestaat, maar dat de beschrijving ervan mede wordt bepaald door de manier waarop een waarnemer een object bekijkt (het Heisenberg-principe). De waarnemer moet eerst uitmaken wat hij wil zien, een deeltje of een golf. In de quantum-mechanica heerst a-causaliteit (geen oorzaak en gevolg en geen tijd en ruimte zoals in de klassieke natuurkunde). Men heeft kunnen aantonen dat in elk punt van de schepping velden bestaan. In deze velden is een onbegrensde hoeveelheid potentiële energie aanwezig. Omdat de velden in staat zijn deeltjes (golven) te produceren, vormen ze de basis van de schepping. De deeltjes die de velden kunnen creëren, hebben verschillende discrete energie-niveaus (daartussen is onmogelijk). Vandaar de benaming quantumveld. Praktische toepassingen van de quantummechanica zien we bijvoorbeeld in de laser, de televisie en de microchip. Indirect heeft de quantummechanica de accounting in aanzienlijke mate beïnvloed, met name door de ontwikkeling van computerapparatuur welke is gebaseerd op deze mechanica.

Als derde grote revolutie in de natuurkunde wordt chaos gezien (Gleick, 1987:15). Evenals in de relativiteitstheorie en in de quantumtheorie wordt hier een aantal uitgangspunten van Newton onderuit gehaald. Stelde de relativiteitstheorie Newtons ideeën over absolute tijd en ruimte ter discussie en rekende de quantumtheorie af met Newtons idee over een beheersbaar meetproces, de chaostheorie maakte een eind aan de deterministische voorspelbaarheid van Laplace die de berekeningen van Newton verfijnder en nauwkeuriger had uitgevoerd. In de chaos-theorie kunnen minuscule verschillen in de invoer tot overweldigende verschillen in de resultaten leiden (Lorenz noemde dit het vlindereffect; Gleick, 1987:17). Ieder punt is instabiel terwijl kleine veranderingen zichzelf kunnen versterken en als het ware kunnen uitvergroten. Het bestaan van niet-lineaire relaties wordt niet langer als een uitzondering beschouwd maar als regel. Feigenbaum ontdekte in het lange-termijn gedrag van sterk uiteenlopende systemen een universele constante ${ }^{52}$, een onverwachte orde dus. Uit de chaostheorie zijn bekend de fractals van Mandelbrot. Een fractal is een manier om onenigheid te kunnen zien, een manier om geconsolideerde effecten te doorgronden ${ }^{53}$. Fractals bepalen geometrisch de 'willekeur' van de vormen in de natuur.

Toepassing van de chaostheorie in accounting houdt in het aandacht hebben voor niétlineariteit. Dit betekent bijvoorbeeld dat bij het uitgangspunt van een lineair lopende vermogensaanwas zoals dat in de conventionele accountingsystemen wordt gehanteerd, vraagtekens worden geplaatst. In triple-entry en momentum accounting wordt echter

\footnotetext{
SI Bij Newton was de wereld als een machine, voorspelbaar en gestaag. God was gevangen in de hierbij ontwikkelde formules.

$\$ 24,6692016090$

53 Zo kan men een Koch-kromme (een soort 'sneeuwvlok') ontleden als cen oplelsom van een oneindige hoeveelheid in elkaar geschoven driehoeken respectievelijk een aantal davidssterren.
} 
nadrukkelijk rekening gehouden met eventuele versnellingen (of vertragingen) in de vermogensaanwas. Derhalve is hier niet-lineariteit uitgangspunt! Ook accentueert de chaostheorie de bijzondere gevoeligheid (het vlindereffect) van complexe systemen (zoals aandelen- en optiemarkten) voor de initiële parameters zoals die worden gehanteerd voor bestudering van de systemen (Etheridge en Sriram, 1993:107).

In de moderne natuurkunde wordt het Hamilton-mechanisme vaak gebruikt om beweging te verklaren. Hierbij worden de relevante bewegingsvergelijkingen afgeleid door het bepalen van het minimum van de van toepassing zijnde integraal (het zogenaamde Hamiltonprincipe). Maar zo'n integraal kan alleen worden gevonden, als het systeem dat het beschrijft geen energie verliest tijdens zijn beweging (een zogenaamd conservatief systeem). Echter, bewegingen van bedrijven kunnen niet zonder opoffering van middelen en derhalve van energie plaatsvinden (output ontstaat slechts bij de opoffering van input). Derhalve moet dit mechanisme voor bedrijfseconomische doeleinden minder geschikt worden geacht.

\subsubsection{Wealth accounting, momentum accounting en force accounting}

Het 'income momentum concept' zoals door ljiri voorgesteld, gaat verder dan het klassieke model van intracomptabele resultaatbepaling. Bij het 'income momentum concept' staat centraal de mogelijkheid van de onderneming om een bepaald resultaat te kunnen blijven genereren. Income momentum kan men in essentie gelijk stellen aan 'earning power' (Ijiri, 1982:21). 'Earning power' is door Edwards en Bell (1961) gedefinieerd als de contante waarde van de in de toekomst realiseerbare netto kasstromen. Bouma noemt deze waarde van de onderneming 'rendementswaarde' (Bouma, 1988:270). Alhoewel beide waarden toekomstgericht zijn, bestaat er een belangrijk verschil tussen 'income momentum' (of winstsnelheid) en 'earning power'. De laatste waarde wordt bepaald door de verwachtingen die iemand heeft inzake de toekomstige financiële mogelijkheden van de ondememing. Bij 'income momentum' gaat het om gerealiseerde gebeurtenissen die de toekomstige winstmogelijkheden van de onderneming beïnvloe$\operatorname{den}^{54}$.

Wanneer op een voorwerp een kracht wordt uitgeoefend, kunnen er in het algemeen drie dingen gebeuren:

1) de snelheid van het voorwerp verandert;

2) het voorwerp wordt vervormd;

\footnotetext{
${ }^{54}$ Als zodanig is 'income momentum' een minder speculatieve waarde. Een voorziene loonstijging bijvoorbeeld wordt bij de berekening van de 'income momentum' niet betrokken maar wél bij de berekening van de 'eaming power'.
} 
3) door de kracht wordt het effect van een andere kracht opgeheven.

Krachten kunnen niet alleen verschillen in grootte, maar ook in richting. Een kracht wordt daarom voorgesteld als een pijl. De lengte van de pijl geeft de grootte van de kracht weer, de richting van de pijl geeft de richting van de kracht aan. De grote bijdrage van Galilei en Newton ligt besloten in het conceptualiseren en meten van dergelijke krachten. De beweging van een object wordt geanalyseerd vanuit de omgevingskrachten die op het object inwerken ${ }^{55}$.

De derde dimensie in differential triple-entry accounting heeft betrekking op het administreren van de gevolgen van het optreden van winstkrachten. Hierbij gaat het om mutaties in bestaande winstkrachten en om de effecten van nieuwe winstkrachten ${ }^{56}$. Op basis van een administratie van de financiële gevolgen van deze krachten kan een systematische en volledige beschrijving worden gegeven van de ontwikkeling in de winstcapaciteit van het eigen vermogen van de onderneming alsmede van de ontwikkeling in het op basis van deze capaciteit periodiek gerealiseerde resultaat.

Wanneer de gezamenlijke winstkrachten een mutatie in de omvang van het eigen vermogen teweeg brengen welke mutatie per definitie tegelijkertijd gaat gepaard met een verandering in de samenstelling van het eigen vermogen, kan vergelijking [4] ook als volgt worden genoteerd (zie ook Ijiri, 1982:22):

$\triangle$ netto activa $=\triangle$ eigen vermogen $=\Sigma$ winstkrachten $[18]$

Indien, zoals gebruikelijk, binnen het eigen vermogen de verlies- en winstrekeningen centraal staan omdat ze de primaire (operationele) veranderingen in de omvang van het eigen vermogen verklaren, kan vergelijking [18] worden geschreven als:

$\triangle$ netto activa $=$ resultaat $=\Sigma$ winstkrachten $[19]^{57,58}$

\footnotetext{
55 In 'strategic management accounting' wordt cen zelfde uitgangspunt gevolgd bij de beoordeling van de financiele ontwikkeling (=beweging) van een bedrijf.

${ }^{56}$ In het vervolg worden mutaties in bestaande winstkrachten ook als 'nieuwe' winstkrachten beschouwd.

${ }^{57}$ Ijiri pleit voor het opnemen van cumulatieve cijfers in de resultatenrekening. Op deze manier zijn netto activa en resultaat in de zelfde periode uitgedrukt (vanaf de oprichting van de onderneming tot en met heden). Het periodicke resultaat kan eenvoudig worden bepaald door twee cumulatieve punten met elkaar te vergelijken. Het voordeel van gecumulcerde resultaatcijfers is dat dit een continu-grootheid is waardoor bepaalde (wiskundige) transformaties mogelijk worden, zoals toepassing van de differentiaalrekening.

${ }^{58}$ De relatie die vergelijking 19 beschrijft is een relatic tussen voorraad, stroming en stromingsversnelling. Wanneer men een emmer onder cen kraan plaatst om de emmer te vullen, kan men de stroming die na een bepaalde tijd in de emmer is gevloeid als volgt meten:

1) indirect door het vergelijken van het oude met het nieuwe waterpeil in de emmer;

2) direct door het meten van de stroming met behulp van een watermeter.
} 
Voorgaande drie-eenheid drukt uit dat winstkrachten een stroming (resultaat) veroorzaken waardoor de voorraad (netto activa) verandert. Omdat we in hoofdzaak zijn geïnteresseerd in de oorzaken van mutaties in het resultaat, schrijven we vergelijking [19] als volgt:

$\Delta \Delta$ netto activa $=\Delta$ resultaat $=\Sigma$ nieuwe winstkrachten [20]

\section{Wealth accounting}

Wanneer het accountingsysteem, zoals bij traditionele accountingsystemen, zich toelegt op het administreren van het linker- en middenlid van vergelijking [20], spreekt Ijiri van 'wealth accounting' (Ijiri, 1987:25). Afgezien van een aantal details zoals het werken met negatieve getallen, komt 'wealth accounting' overeen met het vertrouwde dubbel boekhouden. Wanneer in het accountingsysteem tevens gegevens over het rechterlid van vergelijking [20] worden verwerkt, is sprake van (differential) triple-entry accounting. Hierbij worden oorzaken van winstmutaties (winstkrachten) geadministreerd. Om aansluiting te verkrijgen met de resultatenrekening dienen de gevolgen van de opgetreden winstkrachten in de zelfde periode-eenheid te worden uitgedrukt als de resultatenrekening. Het betreffende overzicht wordt 'action statement', 'overzicht van winstkrachten' of winst-mutatiestaat genoemd ${ }^{59}$. Een dergelijk overzicht geeft een systematische verklaring voor de ontwikkeling in het periodieke resultaat ${ }^{60}$.

\section{Momentum accounting}

Bij hetgeen Ijiri noemt 'momentum accounting' wordt in tegenstelling tot het traditionele 'wealth accounting' er van uitgegaan dat (een bepaald deel van) de winstcapaciteit van de onderneming ook in de toekomst blijft bestaan (winstkrachten gaan niet zonder meer teniet). In aansluiting hierop worden de kosten- en opbrengstenposten niet over een bepaalde periode berekend zoals gebruikelijk is op een resultatenrekening, maar per een bepaalde periode. Een 'momentum statement' of winstsnelheids-staat verschilt derhalve niet van de resultatenrekening voor wat betreft de aard van de posten die op beide overzichten staan vermeld. Het verschil betreft uitsluitend een verschil in tijdaanduiding (en dus in maateenheid) ${ }^{61}$. Een 'momentum statement' is dan ook vergelijkbaar met een

Door het relateren van de gemeten stroming aan de tijd gedurende welke men de kraan heeft opengehouden, wordt inzicht verkregen in de snelheid van de stroming, bijvoorbeeld 1 liter per $1 / 2$ minuut. De verklaring van deze stromingssnelheid ligt echter bij de waterdruk (uitgedrukt in bar) of de kracht dic op het water wordt uitgeoefend. Via een waterdrukmeter zou deze kracht kunnen worden geregistreerd. Het zijn vergelijkbare krachten (winstkrachten) waarover in momentum accounting gegevens worden vastgelegd. Dit kan men opstarten met het opstellen van een balans waarbij alle opbrengsten en kosten als voorraden worden beschouwd en worden uitgednukt als momenta.

${ }^{59}$ Vanzelfsprekend gaat het hierbij uitsluitend om winstkrachten waarvan de invloed in de betreffende verslagperiode is geaffectueerd (realisatie-aspect).

60 'Actie' wordt ook als 'werking' aangeduid.

${ }^{61}$ Momentum accounting is het accountingsysteem dat ontwikkelingen in winstsnelheden vastlegt. Als zodanig is dit in eerste aanleg een én-dimensionaal accountingsysteem. 
balans (een tijdstipoverzicht): het is een overzicht van het kosten- en opbrengstenpotentieel en derhalve van het winstpotentieel zoals dat per een bepaald tijdstip bestaat. Zo zal bijvoorbeeld op een 'momentum statement' van 1 januari 1994 de post onderhoudskosten kunnen voorkomen met ' 100 per maand'. Afgezien van verstorende invloeden (dit zijn winstkrachten) bedragen de onderhoudskosten over 1994 dan 12 x 100= $1200^{62}$. Dit is het bedrag dat op de resultatenrekening over 1994 verschijnt. Een 'momentum statement' is een systematisch overzicht van de winstsnelheid per een bepaald moment, een resultatenrekening is een overzicht van daadwerkelijk gerealiseerde winstsnelheid.

Behalve dat winstkrachten de ontwikkeling in het periodieke resultaat beïnvloeden, wordt ook de 'income momentum' er door bepaald. Het overzicht dat de invloed van de opgetreden nieuwe winstkrachten toont op de 'income momentum' wordt 'impulse statement' of winstsnelheids-mutatiestaat genoemd. Winstsnelheids-staat en de winstsnelheids-mutatiestaat vormen de centrale overzichten in de (twee-dimensionale) momentum accounting.

\section{Force accounting}

In hetgeen ljiri noemt 'force accounting' staat de administratie van groeikrachten centraal $^{63}$. Afhankelijk van de tijddimensie kunnen de invloeden van winstkrachten worden uitgedrukt in guldens over een periode (zoals op de winstmutatie-staat), in guldens per periode (zoals op de winstsnelheids-mutatiestaat) of in guldens per periode per periode. Zo'n laatste overzicht duidt Ijiri aan als 'force statement' en kan winstversnellings-staat worden genoemd. Uit dit overzicht blijkt het vermogen van het bedrijf om in de toekomst versnellingen aan te brengen in de snelheid waarmee geld wordt verdiend. Dit is het winst-acceleratievermogen.

Voor de hier genoemde 'force statements' (winst-mutatiestaat, winstsnelheids-mutatiestaat en winstversnellings-staat) dient (in het (sub)grootboek\} een complete groep nieuwe rekeningen te worden aangelegd. Te denken valt aan rekeningen als 'Nieuwe concurrent', 'Nieuw produkt', 'Verhoging accijnzen', 'Verslechtering algemeen economische situatie', 'Renteverlaging', 'Daling Dollar', enzovoort.

Op een 'winstversnellings-staat' staan de krachten die winstmutaties veroorzaken, uitgedrukt in geldbedragen per maand per maand (of enige andere periode-aanduiding). Een winstkracht van -10 per maand per maand betekent dat de income momentum van

\footnotetext{
${ }^{62}$ Momentum accounting en budgettering vertonen wat dit betreft cen belangrijke overeenkomst. De budgettering kan in dit opzicht worden beschouwd als zijnde een bepaalde verkenning van de aanwezige momenta.

${ }^{63}$ Als zodanig is ook force accounting, ondanks het feit dat met verschillende tijddimensies wordt gewerkt, in eerste aanleg een cén-dimensionaal accountingsysteem.
} 
het bedrijf over 6 maanden zal zijn gedaald met 60 . Op een 'winstversnellings-staat' staan derhalve gegevens opgenomen over winstkrachten die langdurige (structurele) winstimpulsen veroorzaken ('recurring impulses') ${ }^{64}$. Voor het doen van voorspellingen omtrent momentum en resultaat zijn gegevens omtrent deze krachten van groot belang.

In tabel 7.9 zijn de verschillen tussen wealth accounting, (differential) triple-entry accounting, momentum accounting en force accounting zoals die in het voorgaande aan de orde zijn gekomen, samengevat.

Figuur 7.1 schetst nogmaals de in het voorgaande besproken relaties zoals die bestaan tussen groeikracht, impuls, winstmutatie, winst, income momentum en ontwikkelingen in de omvang van het eigen vermogen.

Tabel 7.9 Wealth accounting, versus (differential) triple-entry accounting versus momentum accounting versus force accounting.

\begin{tabular}{|c|c|c|c|}
\hline $\begin{array}{l}\text { accounting- } \\
\text { systeem }\end{array}$ & $\begin{array}{l}\text { belangrijkste } \\
\text { overzichten }\end{array}$ & aard van de posten & maateenheid \\
\hline $\begin{array}{l}\text { wealth } \\
\text { accounting } \\
\text { (accounting van } \\
\text { vermogen en } \\
\text { winst) }\end{array}$ & $\begin{array}{l}\text {.balans } \\
\text {.resultatenrekening }\end{array}$ & $\begin{array}{l}\text { activa en passiva } \\
\text { (categorische) kosten } \\
\text { en opbrengsten }\end{array}$ & $\begin{array}{l}\text {-guldens } \\
\text {.guldens }\end{array}$ \\
\hline $\begin{array}{l}\text { triple-entry } \\
\text { accounting } \\
\text { (accounting van } \\
\text { vermogen, winst } \\
\text { en winstmutaties) }\end{array}$ & $\begin{array}{l}\text {.balans } \\
\text {.resultatenrekening } \\
\text {.winst-mutatiestaat }\end{array}$ & $\begin{array}{l}\text {.activa en passiva } \\
\text { (categorische) kosten } \\
\text { en opbrengsten } \\
\text {. winstkrachten } \\
\text { (acties) }\end{array}$ & $\begin{array}{l}\text { guldens } \\
\text { guldens } \\
\text { guldens }\end{array}$ \\
\hline $\begin{array}{l}\text { momentum } \\
\text { accounting } \\
\text { (accounting van } \\
\text { winstsnelheden) }\end{array}$ & $\begin{array}{l}\text { winstsnelheids- } \\
\text { staat } \\
\text {.winstsnelheids- } \\
\text { mutatiestaat }\end{array}$ & $\begin{array}{l}\text { (categorische) kosten } \\
\text { en opbrengsten } \\
\text {.winstkrachten } \\
\text { (impulsen) }\end{array}$ & $\begin{array}{l}\text { guldens } \\
\text { per maand } \\
\text { guldens } \\
\text { per maand }\end{array}$ \\
\hline $\begin{array}{l}\text { force } \\
\text { accounting } \\
\text { (accounting van } \\
\text { groeikrachten) }\end{array}$ & $\begin{array}{l}\text {.winstversnellings- } \\
\text { staat }\end{array}$ & $\begin{array}{l}\text {. winstkrachten } \\
\text { (groeikrachten) }\end{array}$ & $\begin{array}{l}\text { guldens } \\
\text { per maand } \\
\text { per maand }\end{array}$ \\
\hline
\end{tabular}

\footnotetext{
${ }^{64}$ Op een winstsnelheids-mutatiestaat worden de gevolgen opgenomen van 1) structurele groeikrachten (van de winstversnellings-staat) en 2) cenmalige impulsen (incidentele versnellingen).
} 
Figuur 7.1 De relaties tussen groeikracht, impuls, winstmutatie, winst, income momentum en ontwikkelingen in de omvang van het eigen vermogen.


Theoretisch is het mogelijk dat naast samenstelling en omvang van het eigen vermogen en het administreren van winstversnellingen ook nog eens veranderingen van winstversnellingen worden geadministreerd ${ }^{65}$. In dit geval is sprake van een vier-dimensionaal

${ }^{65}$ In dit geval zou een winstversnellings-muatiestaat rechtstreeks uit de administratie kunnen worden opgemaakt. 
accountingsysteem of '(differential) quadrupple-entry accounting'. ljiri werkt een bepaalde vorm van quadrupple-entry accounting nader uit: 'benefit accounting'. Hiertoe werkt hij het conventionele wealth accountingsysteem uit in de andere richting, dat wil zeggen: de tijds-integralen in plaats van tijdsdifferentialen. 'Benefits' definieert Ijiri als 'something that are enjoyed by holding and utilizing wealth' (Ijiri, 1989:77). Deze voordelen uit hoofde van het aanhouden van netto activa of 'wealth' kunnen bijvoorbeeld worden onderverdeeld in voorraadwinst en verkoopwinst. De redenering is nu als volgt: (1) winstkrachten creëren (2) bepaalde momenta die (3) veranderingen in de netto activa teweeg brengen waarbij (4) het gebruik en aanhouden ('uitbaten') van deze activa veranderingen in voordelen teweeg brengen. $\mathrm{Bij}$ benefit accounting gaat het niet om de administratie van eigendommen maar om het gebruik daarvan ('wealth-utilization'66). Doordat bij momentum accounting winst op continu wijze wordt erkend, ligt het (potentiële) gebruik van activa anders dan bij de traditionele wealth accounting waarbij winst op discrete tijdstippen wordt genomen. Als benadering van het gebruik van de beschikbare activa neemt men bij wealth accounting vaak het gemiddelde van het vermogen dat per het begin en per het einde van de betreffende verslagperiode beschikbaar was. Benefits, wealth, momenta en krachten noemt Ijiri de sleutelsectoren van de totale measurement accountingstructuur (Ijiri, 1989:84).

Bij het analyseren van de financiële gevolgen van transacties wordt het onderscheid tussen wealth accounting en triple-entry en momentum accounting pas echt goed zichtbaar.

Het uitbetalen van loon of het ontvangen van huur is bij momentum accounting geen te administreren feit. Dergelijke betalingen of ontvangsten vormen immers slechts realisaties van in het verleden gecreëerde winstkrachten ${ }^{67}$. Door deze betalingen verandert de winstsnelheid niet en derhalve is evenmin een winstmutatie het gevolg. Daarentegen is het sluiten van het looncontract een feit dat in wealth accounting niet wordt geadministreerd maar in momentum accounting wél omdat de winstsnelheid afneemt en een winstmutatie het successievelijke gevolg zal zijn.

\subsubsection{Postulaten bij momentum accounting}

Voor het praktisch kunnen uitvoeren van een systeem van momentum accounting heeft Ijiri een drietal postulaten gedefinieerd (Ijiri, 1987:31):

\footnotetext{
66 'Wealth utilization' $=$ wealth $\times$ tijd

${ }^{67}$ Hierbij wordt eenvoudigheidshalve afgezien van het feit dat door het betalen casu quo ontvangen van gelden een bepaald rente-effect wordt opgeroepen. Bij benefit accounting wordt hiermee nadrukkelijk wél rekening gehouden.
} 
1) Het instandhoudingscriterium ('momentum conservation'). Tenzij er objectief bewijsmateriaal bestaat dat de momentum is veranderd, wordt aangenomen dat de momentum in de tijd gelijk blijft ${ }^{68}$.

Dit bewijsmateriaal is overduidelijk bij het aangaan van een contract. Maar ook bijvoorbeeld bij een groot aantal aankopen door een grote groep klanten zonder verdere contractuele aankoopverplichting is een income momentum vast te stellen. Hierbij kan worden gebruik gemaakt van statistische procedures zoals het analyseren van historische reeksen van afzetcijfers. Op basis hiervan wordt een voorspelling gemaakt van de winst terwijl bij eventuele fouten ("error terms ${ }^{\text {,69 }}$ ) het (adaptieve) model wordt aangepast. Aldus wordt een soort updating mechanisme ingebouwd, waardoor het model snel of minder snel (afhankelijk van de gekozen parameters ${ }^{70}$ ) door het beschikbaar komen van nieuwe gegevens wordt bijgesteld. Een bekend voorbeeld van zo'n voorspellingsmodel is het Holt-Winters exponentiële model. Hierbij wordt aan gegevens die verder weg in het verleden liggen, steeds (exponentieel) minder betekenis toegekend (Newbold, 1984:717).

Overigens kunnen in de veronderstelling van gelijkblijvende income momenta de nodige gradaties worden aangebracht, bijvoorbeeld doordat ten aanzien van bepaalde opbrengsten zekere fricties (weerstanden) worden verondersteld. Net zoals bij een machine met behulp van afschrijvingspercentages een bepaald afschrijvingsverloop wordt weerspiegeld, kan men bij opbrengsten met behulp van soortgelijke percentages eveneens een bepaalde graad van afname ('uitholling') tot uitdrukking brengen. Een frictiepercentage van $20 \%$ betekent in dit geval dat slechts $80 \%$ van de omzet van dit jaar in het volgende jaar zal worden behaald, er van uitgaande dat het bedrijf zich in het volgende jaar geen extra verkoopinspanningen getroost.

2) Het causaliteitsprincipe ('momentum attribution').

Elke verandering in de momentum dient te worden verklaard via een impuls. Een

\footnotetext{
${ }^{68}$ Wanneer men deze gedachte doortrekt kan men momentum accounting vergelijken met een budgetteringssysteem (alleen de maatcenheid verschilt) waarbij men het budget van het afgelopen jaar als uitgangspunt ncemt om hierop vervolgens al dan niet enkele correcties toe te passen. Wealth accounting en dus het traditionele accountingsysteem is in dit opzicht een (onbewuste?) toepassing van de zero-base budgettering: men neemt aan dat iedere verslagperiode opnieuw alle kosten en opbrengsten met de zelfde inspanning als in de vorige periode dienen te worden gerealiseerd.

${ }^{69}$ Deze foutterm geeft aan dat niet alle veranderingen in het winstcijfer door veranderingen in momenta kunnen worden verklaard. De foutterm is gelijk aan het verschil tussen de winst en de over de betreffende verslagperiode geïntegreerde momentum.

${ }^{70}$ Deze parameters zijn afhankelijk van het vertrouwen dat men heeft in bijvoorbeeld de splitsing die is gemaakt in incidentele omzet en structurele omzet. Indien men deze scheiding met de losse hand heeft moeten aanbrengen, zal men de $\alpha$ in het model zeer laag instellen zodat aanpassingen vrij langzaam worden doorgevoerd.
} 
impuls is het effect van een groeikracht vermenigvuldigd met de periode waarover deze kracht zich uitstrekt ${ }^{71}$.

$$
\text { impuls }=\text { groeikracht } \times \text { tijd }[21]
$$

Het saldo der impulsen dient gelijk te zijn aan de uiteindelijke verandering in de momentum.

$$
\Sigma \text { impuls }=\triangle \text { momentum }[22]
$$

Wanneer we een impuls in zijn tijd integreren, ontstaat wat Ijiri noemt actie $^{72}$. Dat wil zeggen: bij een constante impuls geldt

$$
\text { actie }=\text { impuls } \times \text { tijd }[23]
$$

Actie is aldus de manifestatie van impuls.

Wanneer we vergelijking [21] en [23] aan elkaar relateren, ontstaat

$$
\text { actie }=\text { groeikracht } \times \text { tijd } \times \text { tijd }=\text { groeikracht } \times \text { tijd }^{2}[24]
$$

De eerste afgeleide naar tijd van actie geeft impuls terwijl de eerste afgeleide naar tijd van impuls (=de tweede afgeleide naar tijd van actie) de winstkracht (als groeikracht) oplevert.

De mate waarin een bepaalde winstkracht de winstsnelheid en winst beïnvloedt, is een kwestie van winstelasticiteit $^{73}$. Spreadsheet-analyses kunnen bij het onderzoek naar deze elasticiteit goede diensten bewijzen.

\section{3) Het afstemmingsprincipe ('momentum reconciliation').}

In momentum accounting wordt verondersteld dat alle resultaten continu worden gerealiseerd (en niet discreet zoals in 'wealth accounting'). Dit kan problemen geven met betrekking tot de afstemming tussen de resultaten volgens 'wealth accounting' en de resultaten volgens 'momentum accounting'. Winst die volgens de uitgangspunten

\footnotetext{
${ }^{71}$ Impuls is de integraal van winstkrachten over de tijd waarbinnen zich deze krachten hebben kunnen uitstrekken. Overigens wordt in de natuurkunde het begrip 'impuls' meestal gebruikt wanneer een kracht zich uitstrekt over een betrekkelijk korte periode. Voor onze doeleinden is dit uitgelegd als 'in de verslagperiode'.

${ }^{72}$ In de mechanica wordt de term 'actie' gebruikt voor het produkt van (kinetische minus potentièle) energie en tijd. Met andere woorden: actie is de tijdsintegraal van energie. Voor onze doeleinden kan actic worden vitgelegdl als 'winstmutatie'.

${ }^{73}$ Vergelijk het begrip clasticiteit zoals dat in de algemene economie wordt gehanteerd.
} 
van 'wealth accounting' nog niet is gerealiseerd, dient binnen 'momentum accounting' te worden geactiveerd. De afboeking hiervan vindt plaats in de verslagperiode waarin binnen 'wealth accounting' het betreffende bedrag is verantwoord als zijnde gerealiseerd ${ }^{74}$.

\subsubsection{Winstkrachten nader bezien}

De invloed van een winstkracht op de winstcapaciteit van het eigen vermogen van de ondermeming dient te worden gemeten over de totale periode waarover de kracht zich uitstrekt. Zoals bij verlies- en winstrekeningen kan in dit verband ten aanzien van krachten een onderscheid worden gemaakt tussen incidentele en structurele winstversnellingen. Een impuls is hierbij te zien als een kortstondige winstkracht waarbij de invloed van de kracht is uitgedrukt in de momentum-mateenheid. Een verhoging van de winstbelasting door de overheid is een voorbeeld van een incidentele winstversnelling (of liever: vertraging). Stel dat hierdoor de nettowinst-capaciteit van een ondememing daalt met 20 per maand. Op de winstsnelheids-mutatiestaat over het betreffende jaar staat dan debet 'Verhoging winstbelasting $20^{\prime}$. Stel dat de belastingverhoging in oktober is ingegaan, dan staat debet op de winst-mutatiestaat over dat jaar 60. Afgezien van andere winstkrachten is de winst in het betreffende jaar 60 lager dan in het voorafgaande jaar en is de income momentum per het eind van dat jaar 20 lager dan per het eind van het jaar ervoor. Op de winstversnellingsstaat wordt van de overheidsmaatregel niets opgenomen omdat er geen verder toekomstig effect van dit besluit uitgaat, dat wil zeggen: de income momentum zal er niet verder door worden aangetast. Afgezien van de invloed van andere winstkrachten zal de mutatie in de income momentum in het komende verslagjaar nihil zijn. Een deel van de in het vorige jaar gedaalde winstsnelheid wordt evenwel pas in het komende jaar gerealiseerd. De nettowinst in het komende jaar is daarom 180 lager dan in dit jaar. Deze differentie heeft evenwel niets te maken met het optreden van nieuwe winstkrachten, maar is puur een gevolg van toegepaste realisatie-conventies (een kwestie van 'timing').

In geval van een structurele winstversnelling ('force'), zoals bij een toegekende loonsverhoging van $2 \%$ per jaar gedurende 3 jaar, worden bij toepassing van force accounting ook de toekomstige mutaties in de income momentum geadministreerd. Dergelijke groeifactoren worden geactiveerd op de winstversnellings-staat.

\footnotetext{
${ }^{74}$ In dit opzicht is momentum accounting ondergeschikt gemaakt aan wealth accounting. Verwonderlijk is dit niet, immers momentum accounting vindt plaats op een hoger abstractie-niveau.
} 
Winstkrachten kunnen ook worden onderscheiden in interne en externe winstkrachten. In verband met het beoordelen van het management ('managerial performance') kan een dergelijke opsplitsing van groot belang zijn. Ijiri onderscheidt met name de volgende interne en externe krachten (Ijiri, 1986:759):

\section{Extern}

Concurrentiekrachten

Algemeen economische (conjuncturele) krachten

Overheidskrachten

Internationale krachten

en Natuurkrachten.

Intern
Investeringen
Desinvesteringen
Arbeidskrachten
R\&D-krachten
Produktiekrachten
Marketingkrachten ${ }^{75}$
en Financieringskrachten.

Wat het selecteren van de te administreren winstkrachten betreft, kan in eerste aanleg worden aangesloten bij het marketingconcept van de kritieke succesfactoren ${ }^{76}$. Dit zijn de sleutelgebieden waarin de dingen goed moeten gaan, wil het bedrijf floreren. Om wat meer zicht te krijgen op de belangrijkste resultaatbepalende factoren, is een eigen overigens weinig pretentieus - onderzoek uitgevoerd onder 75 van de 140 ter beurze genoteerde actieve en binnenlandse aandelen (achter in het boek in de bijlage bij dit hoofdstuk is een lijst van de onderzochte bedrijven opgenomen). Het betreft hier een onderzoek naar de toekomstpassage zoals die in het jaarverslag 1992 was opgenomen. In de eerste plaats is nagegaan of het betreffende management inderdaad een winstvoorspelling voor 1993 deed. In tabel 7.10 zijn de onderzoeksresultaten samengevat.

\footnotetext{
${ }^{75}$ Hiertoe kunnen worden gerekend de waarderingen zoals die door de consument aan een produkt of dienst worden loegekend (zie in dit verband ook voetnoot 11 bij hoofdstuk 4)

${ }^{76}$ Belangrijkste boodschap van dit concept is in dit verband dat de aandacht van het administratieve management niét dient uit te gaan naar bijvoorbeeld 100 of meer triviale winstkrachten maar dat er een uitgekiende selectie dient plaats te vinden zodat de aandacht kan worden geconcentreerd op een beperkt aantal factoren.
} 
Tabel 7.10 Opgenomen winstvooruitzichten voor 1993.

\begin{tabular}{|l|c|}
\hline $\begin{array}{l}\text { Indicatie voor het resultaat } \\
\text { over } 1993\end{array}$ & aantal bedrijven \\
\hline vergelijkbaar & 13 \\
\hline stijging & 17 \\
\hline daling & 11 \\
\hline onthouding & 24 \\
\hline geen & $10^{77}$ \\
\hline Totaal & 75 \\
\hline
\end{tabular}

Omdat vergelijkende cijfers ontbreken, kan omtrent de relatieve betekenis van de gevonden uitkomsten geen definitieve uitspraak worden gedaan. Wanneer het aantal 'stijgers' in de tijd groeit, kan dit worden uitgelegd als een 'stijgend vertrouwen in de economie'. Echter hierbij dienen tevens in de beschouwing te worden betrokken de doorslaggevende factoren waarop de door het management gedane voorspellingen zijn gebaseerd. Deze factoren zijn te interpreteren als de kritieke succesfactoren of (kritieke winstkrachten) $)^{78}$. In 61 van de 75 onderzochte bedrijven (ruim $81 \%$ ) werd verwezen naar de algemeen economische vooruitzichten. In 25 van de 75 gevallen werd de kostenbeheersing (bedrijfsefficiency) genoemd als belangrijk aandachtsveld ${ }^{79}$. Andere winstbepalende krachten die veelvuldig werden genoemd betroffen de ontwikkeling van de rente ( 8 op de 75 ; met name genoemd in de kapitaalintensieve sectoren zoals de chemische industrie), de ontwikkeling van de dollar (7 op de 75), de ontwikkeling van de lonen (6 op de 75; met name genoemd in de arbeidsintensieve sectoren, zoals de detailhandel), overheidsmaatregelen waaronder besluiten van de Europese Commissie ( 8 op de 75, met name genoemd in de transportbranche en de aan de gezondheidszorg leverende industrie), en de invloeden van het weer ( 2 van de 75 , met name van belang voor de bierbrouwerijen). Expliciet werd ook verwezen naar de ontwikkeling van grondstof- en afzetprijzen (6 van de 75), financiële structuur (7 van de 75), merkbekendheid (5 van de 75), produktkwaliteit (6 van de 75), de politieke situatie in bepaalde landen (2 van de 75 ) en verbeterde informatiesystemen (3 van de 75, expliciet genoemd bij Ahrend, KBB en

\footnotetext{
${ }^{77}$ In de jaarverslagen van Alag, Blijdenstein-Willink, Breevast, Content, Eriks, Gamma, Nedap, Nedlloyd, Unilever, en Springstoffenfabricken was geen enkele directe verwijzing naar het over 1993 verwachte resultaat opgenomen.

${ }^{78}$ Alhowel het hier in principe gaat om de winsthepalende factoren op korte termijn.

${ }^{79}$ Het is evident dat wanneer een verwachte stijging van het resultaat voomamelijk op kostenbeheersing en efficiencyverbetering is gebaseerd of op bijvoorbeeld acquisitic, een toename van het aantal 'stijgers' niet zonder meer kan worden geïnterpreteerd als zijnde een toename van het vertrouwen in de economie. In de onderzochte gevallen werd slechts bij 2 van de 17 'stijgers' expliciet verwezen naar kostenbeheersing en efficiencyverbetering respectievelijk acquisitie. Hierbij zijn evenwel geen verwijzingen naar met name loon- en rente-ontwikkelingen betrokken.
} 
Macintosh). Sporadische factoren die werden genoemd waren flexibiliteit, levertijden, technologie, risicobeheersing, distributie, logistiek, inkoopbeleid en doorlooptijden ${ }^{80}$.

Alhoewel bovenstaande cijfers enige tendentie aangeven voor de resultaatbepalende factoren, kan niet worden gesproken van een ideaaltypering van de te administreren winstkrachten. De beslissende winstkrachten verschillen van bedrijf tot bedrijf en voor zover er sprake is van de zelfde winstkrachten kan de mate waarin deze krachten van betekenis zijn, sterk per bedrijf verschillen.

\subsection{Winstkrachten en financieel-economische berichtgeving}

In dit triple-entry en momentum accounting-onderzoek is de gedachte gevolgd dat een aantal relevante gegevens in management accountingsystemen ontbreken (en - wellicht mede daardoor - ook in de externe verslaggeving), doordat slechts twee dimensies van het eigen vermogen van een bedrijf worden geregistreerd. Bij toepassing van differential triple-entry accounting wordt een derde dimensie ingevoerd en geadministreerd: geanalyseerd wordt het effect van transacties op het vermogen in samenstelling (=hoeveelheid) en in waarde zoals dit in een twee-dimensionale administratie gebeurt, uitgebreid met een administratie van ontwikkelingen in winstniveau's (zijnde ontwikkelingen in de ontwikkeling van de omvang van het eigen vermogen). Hiertoe worden gegevens over winstkrachten verzameld en verwerkt. Winstkrachten veroorzaken mutaties in de winstsnelheid en (daardoor) in de winst.

In een twee-dimensionaal accountingsysteem wordt (impliciet) verondersteld dat de winstsnelheid in de tijd constant blijft ('constant income momentum'). Doordat gegevens over ontwikkelingen in winstsnelheden niét in de vigerende accountingsystemen worden verwerkt, staan de hierbij verkregen financiële overzichten niet meer model voor de bedrijfswerkelijkheid die ze beogen te representeren of waarvan redelijkerwijze mag worden verwacht dat ze die representeren. Dit is een aspect van 'representational faithfulness'. Wanneer het accountingsysteem de werkelijkheid onvoldoende reflecteert en derhalve de aan dit systeem te ontlenen gegevens onvolledig zijn, is per definitie ook de 'predictive value' casu quo de 'feedback value' gering. Hiermee is de relevantie van het systeem in het gedrang. Via het toevoegen van een derde dimensie aan het meet-spectrum van het accountingsysteem, wordt met differential triple-entry casu quo momentum accounting getracht de onvolledigheid van vigerende management accountingsystemen te verdringen en daarmee de relevantie terug te brengen.

\footnotetext{
${ }^{80}$ Ook capaciteitsbenutting werd veelvuldig genoemd in de toekomstpassage (10 van de 75). Maar hier is geen sprake van een oorspronkelijke winstkracht zodat dit aspect buiten de analyse is gelaten.
} 
Ook externe gebruikers van financiële overzichten kunnen veel baat hebben bij gegevens over de ontwikkeling van de winstcapaciteit van de onderneming. In dit verband kan men de vraag stellen: kan met de huidige wijze van verslaglegging worden voldaan aan de in de wet genoemde algemene eis van inzicht wanneer gegevens over de winstcapaciteit ontbreken? Dat de huidige wijze van (externe) verslaglegging onvoldoende is, komen we ook tegen in de discussies over het kasstroomoverzicht. In het jaarverslag 1989 van Elsevier is de volgende passage opgenomen:

... "Taal en methode van de traditionele jaarrekening zijn kennelijk ontoereikend voor een genuanceerde weergave van de economische processen in een moderne onderneming" (1989:13).

Het management van Elsevier probeert de gesignaleerde tekortkomingen te ondervangen door met ingang van 1989 een SHBM te publiceren, voorafgaand aan de winst en verliesrekening (hiermee werd feitelijk gezegd dat cash flow belangrijker is dan winst) en door het geven van nadere toelichting op de winst- en verliesrekening.

In 1988 publiceerde het Institute of Chartered Accountants of Scotland een discussierapport ('Making Corporate Reports Valuable') inzake conceptual frameworks en financial accounting. Een van de conclusies uit dit rapport was als volgt:

"De huidige jaarrapporten zijn onbevredigend omdat ze zich te veel bezighouden met de juridische vorm van transacties in plaats van met de economische betekenis (economic substance), omdat ze zich koncentreren op het verleden, omdat ze zich koncentreren op kosten in plaats van op waarde en omdat ze te veel aandacht schenken aan winst en niet aan welvaart (wealth)" (Knoops, 1991:45).

Fox en Goldratt vergelijken in dit verband een bedrijf met een geldmachine. Hierbij gaat het met name om de mate waarin (de snelheid waarmee) met die machine geld kan worden verdiend ('the rate of generating money'). Ook van belang zijn het in de machine geïnvesteerde vermogen en het bedrag dat periodiek moet worden uitgegeven voor het onderhoud van de machine. Vervolgens merken Fox en Goldratt op:

"So it is reasonable to expect that we will be able to find some evidence that these measurements - the rate of generating money, the money captured, and the money spent to move the wheels - are certainly not the traditional bottom line measurements. They are not the profit and loss statement or the balance sheet. Likewise, these three measurements are not our costbased procedures. We see that they don't have place in our formal system, but do they exist as part of the informal system?" (1989:19). 
Wanneer we in de beeldspraak van Fox en Goldratt blijven, is het in hoofdzaak 'the rate of generating money' waarover in traditionele accountingsystemen geen verslag wordt gedaan. In differential triple-entry en momentum accounting wordt deze dimensie van de 'geldmachine', de income momentum, wél (systematisch en regelmatig) geadministreerd. Zoals Fox en Goldratt suggereren kan het zijn dat in de praktijk de ontwikkeling in de winstsnelheid van het eigen vermogen van de onderneming met behulp van informele systemen wordt geadministreerd. Het voordeel van differential triple-entry en momentum accounting is dan dat de administratie van de derde dimensie van het eigen vermogen via boekingsregels wordt getheoretiseerd en gesystematiseerd zodat deze kan worden opgenomen in het formele accountingsysteem. Uit bestuurlijk informatie-oogpunt is dit in verband met de continuïteit en stelselmatigheid van wezenlijk belang.

In accounting geïnteresseerde informatie-specialisten zoals Feltham suggereerden reeds jaren terug dat accountingsystemen die zich concentreren op het registreren van vermogen en winst, eventueel aangevuld met gegevens over herkomst en besteding van middelen, een te eng perspectief behelzen. Feltham stelt dat met name aan management accountingsystemen toekomstgerichte gegevens en niét-financiële gegevens moeten kunnen worden ontleend (1968:692). Bell legt de gedachte van Feltham als volgt uit voor wat betreft de administratieve consequenties.

"Reporting budgeted data, and then actual performance in a manner consistent with the data on budgets, would be one simple step that would be in line with what Feltham was suggesting" (Bell, 1986:23).

Dit is een pleidooi voor temporal triple-entry accounting. Ook Beaver en Demski stellen dat toekomstgerichte gegevens de gegevens zijn die het accountingsysteem dient te verwerken (Beaver en Demski, 1979:46; Demski, 1986:74).

Bij toepassing van differential triple-entry en momentum accounting wordt de veronderstelling van 'constant income momentum' losgelaten en wordt het accent gelegd op het administreren van oorzaken van winstmutaties. Dit betekent bijvoorbeeld dat het beschikbaar komen van een nieuw of verbeterd produkt uit de research-afdeling, het converteren van kortlopend vreemd vermogen in goedkoper langlopend vreemd vermogen, het bericht van de bank waarbij de rente op de opgenomen leningen is verhoogd en een substantiële wijziging in een valutakoers financiële feiten zijn.

Het waarderen van sommige van deze feiten kan de accountant voor grote problemen stellen, zowel ten aanzien van het tijdstip waarop ('de timing'), als ten aanzien van het bedrag waartegen de financiële gevolgen zullen worden geadministreerd. Het vereist dat de accountant tezamen met het management anticipeert op onzekere geldelijke effecten. 
Maar, de belangrijkste taak van het management is 'vooruitzien' en het management kan zich daarom niet aan deze verantwoordelijkheid onttrekken. Anders gezegd: het administreren van de winstsnelheid van het eigen vermogen zou kunnen voorkomen dat het management er een ongerechtvaardigd myoop gedrag op na houdt ${ }^{81}$.

Of het management op de gevolgen van externe gebeurtenissen voor de winstsnelheid van het bedrijfsvermogen wordt beoordeeld, is een kwestie van andere orde. Men kan immers stellen dat het management uitsluitend verantwoordelijk is voor zaken die het kan beheersen ('controllability'-principe). Aan de andere kant zou men kunnen stellen, dat het management op dergelijke zaken dient te anticiperen en het derhalve ook verantwoordelijk is voor dit type omstandigheden ${ }^{82}$.

Alhoewel dit onderzoek zich niet in het bijzonder richt op de administratief organisatorische aspecten van triple-entry en momentum accounting, is het voor een totaal-indruk van een dergelijk systeem van belang hier toch kort bij stil te staan.

Algemeen worden transacties gezien als het vertrekpunt van het accountingproces. Transacties gaan vergezeld van boekingsdocumenten welke voor de accountant het objectieve bewijs vormen dat tot aintekening kan worden overgegaan. Hierbij moeten de documentgegevens aan bepaalde criteria voldoen.

"... the conventional accounting model accepts data from the environment only if it meets certain requirements. Data must be economic in nature, refer to the corporate entity, be subject to quantification and be verifiable. (Armitage en Skelton, 1987:53).

Over het administreren van financiële gegevens wordt in het IASC-conceptual framework opgemerkt:

"...an element should be recognised if: (a) it is probable that any future economic benefit associated with the item will flow to or from the enterprise; and (b) the item has a cost or value that can be measured with reliability" (IASC, 1989:28).

In beide voorgaande benaderingen wordt niets opgemerkt over de mogelijke keuze die moet worden gemaakt tussen relevantie en betrouwbaarheid. Wanneer gegevens over winstsnelheid een belangrijke voorspellende waarde bezitten, kan het van belang blijken deze te administreren, ook al zouden de betreffende gegevens minder goed objectief verifieerbaar zijn.

\footnotetext{
${ }^{81}$ Bovendien zal na verloop van tijd een leereffect kunnen optreden waardoor de 'kalibrate', dit is de mate van overecnstemming tussen voorspelling en werkelijke uilkomst, kan toenemen.
}

82 Dearden heeft dit aspect uitgewerkt in wat hij noemt "the influencability principle". Hiermee wil hij aangeven dat managers meestal ook verantwoordelijk worden gehouden voor zaken waarover ze minder dan volledige beheersing hebben (1987:86). 
Het is de vraag of in geval van differential triple-entry en momentum accounting gerealiseerde transacties nog steeds de 'trigger' of aanjager van het accountingproces zijn en blijven (dit is een vraag van 'recognition'). Transacties zijn het gevolg van beslissingsprocessen en men kan als zodanig stellen dat het moment van de (gedocumenteerde) beslissing een beter uitgangspunt is bij de interne verslaglegging. Vanaf dat moment immers staat ondubbelzinnig vast dat de financiële positie van de onderneming in een bepaalde richting wijzigt ${ }^{83}$. Het ontwerpen van adequate administratieve procedures in dezen zal evenwel nog jaren in beslag nemen. Maar de huidige berichtgeving heeft hier ook zo'n 500 jaar over gedaan...

Op basis van de in paragraaf 5.2 genoemde kwalitatieve eisen die aan accountinggegevens kunnen worden gesteld, kan ook de waarde van het in dit onderzoek beschreven drie-dimensionaal en momentum accountingsysteem worden bepaald door mogelijke verbeteringen te meten in de onderscheiden kenmerken. Echter, de aan genoemde gegevens te stellen kwaliteitseisen zijn vrij globaal gedefinieerd en bovendien interdependent. Dit betekent dat er de nodige meetproblemen zullen ontstaan, waardoor de interpretatie van de onderzoeksresultaten onvoldoende eenduidig kan zijn. Om deze reden is in dit onderzoek voor een andere aanpak gekozen, namelijk door te meten in hoeverre het nieuwe informatiesysteem bijdraagt tot kwalitatief betere voorspellingen bij de gebruiker. Hiertoe is een experiment uitgevoerd waarvan in hoofdstuk 9 de resultaten zullen worden besproken.

\subsection{Samenvatting}

De ontwikkeling van enkel boekhouden naar dubbel boekhouden is vergelijkbaar met de (mogelijke) ontwikkeling van dubbel boekhouden naar triple-entry accounting. In de periode van het enkel boekhouden ging men steeds meer vragen stellen naar de oorzaken van de verandering in het eigen vermogen (de rijkdom). In verband hiermee is men toen vermogens-rekeningen gaan administreren. In eerste instantie deed men dit extracomptabel, in welk geval er sprake is van uitgebreid enkel boekhouden. Naderhand is men de mutaties in het eigen vermogen volledig en systematisch gaan analyseren door het intracomptabiliseren van de vermogensrekeningen. Dit was het begin van het dubbel boekhouden. Het dubbel boekhoudmodel van Pacioli kwam er op neer dat hij tussen twee balansen een verklarend overzicht opstelde: de resultatenrekening. ljiri tracht nu een verklarend overzicht op te stellen dat betrekking heeft op de vergelijking van twee resultatenrekeningen.

\footnotetext{
${ }^{83}$ In ruime zin valt dit 'aangepaste vertrekpunt' van enig accountingproces nog steeds onder de noemer 'transacties'. "Transactions are economic or financial events that are recorded in the firm"s accounts. An event has been defined in SFAC 3 as "a happening of consequence to an entity" (Wolk, Francis en Tearney, 1992:222).
} 
Naast differential triple-entry accounting dat als een systeem van activity-based accounting kan worden gezien en waarbij de verschillenanalyse volledig in het comptabele systeem is geïntegreerd, onderscheidt Ijiri een systeem van temporal triple-entry accounting. Hierbij wordt het begrotings-casu quo budgetsysteem volledig in het comptabele systeem geïntegreerd. In differential triple-entry accounting vindt een systematische administratie van winstkrachten ('income forces' of profit-drivers') plaats. De winsteffecten van dergelijke krachten kunnen worden gemeten:

1) in guldens en derhalve als acties;

2) in guldens per periode en derhalve als impulsen; en

3) in guldens per periode per periode, dat wil zeggen: als groeikrachten (of 'forces').

Winstkrachten veroorzaken ontwikkelingen in het periodieke resultaat, in de 'income momentum' (winstsnelheid) en in het winst-acceleratievermogen. Op basis van de administratie van winstkrachten kan voor genoemde ontwikkelingen een systematische en oorzakelijke verklaring worden gegeven.

Het is waarschijnlijk dat wat ljiri als (temporal casu quo differential) triple-entry accounting aanduidt in het bedrijfsleven al in zekere opzichten wordt toegepast. Zo beschikt bijvoorbeeld Ahold over een hoogwaardig geautomatiseerd informatiesysteem met behulp waarvan elke week de gevolgen kunnen worden geanalyseerd van een hogere loonsom, een verscherping van de recessie of bijvoorbeeld een lagere dollar. Ook Holland Casino's beschikt over een vergelijkbaar geavanceerd intern financieel informatiesysteem. De bijdrage van Ijiri is dat thans dergelijke accountingwerkzaamheden worden geconceptualiseerd en gesystematiseerd en worden geplaatst in het licht van de meer traditionele werkzaamheden. Een zelfde ontwikkeling hebben we kunnen waarnemen toen Pacioli het dubbel boekhouden vastlegde. In zijn Summa geeft Pacioli aan dat hij het boekhouden beschrijft zoals dat al vele jaren in de praktijk plaatsvond. Ondanks dit feit kan niet worden gesteld dat de bijdrage van Pacioli aan de ontwikkeling van het boekhouden casu quo de accounting beperkt is geweest. 


\section{Operationalisering van het concept van triple- entry en momentum accounting}

\subsection{Inleiding}

Triple-entry accounting betekent dat een derde dimensie aan het klassieke administratiemodel wordt toegevoegd en dat derhalve drie dimensies van het (eigen) vermogen van de onderneming worden geadministreerd: samenstelling, omvang en (oorzakelijke) winstmutaties.

Sommige auteurs hebben de drempel van het dubbelboekhouden al jaren geleden genomen. Zo noemt Carmichael (1987:23) het door hem ontworpen systeem 'quad accounting', ofte wel viervoudig boekhouden. Waar het hier om gaat is een geautomatiseerd model van filiaaladministratie ${ }^{1}$. Wanneer in een bedrijf meerdere min of meer zelfstandige eenheden worden onderscheiden (zoals business units of filialen), kunnen bedragen vanaf de boekingsdocumenten automatisch worden doorgeboekt (via totaalrekeningen) op de rekeningen van de betreffende bedrijfseenheid ${ }^{2}$. Voor consolidatie-doeleinden heeft Carmichael een dummy-entiteit ingesteld. Ondanks de aardige opzet van het model, met name ten behoeve van het beheer van groepstructuren, blijft sprake van tweevoudig of dubbel boekhouden. In geen enkel opzicht is voldaan aan de voorwaarden zoals gesteld in hoofdstuk 7 ten aanzien van nieuwe dimensies.

In dit hoofdstuk wordt aan de hand van een uitgewerkt voorbeeld de intracomptabele verwerking van de derde dimensie in een (differential) triple-entry en momentum accountingsysteem uiteengezet. Hierbij worden het differential triple-entry concept en het momentum accounting concept in één systeem geïntegreerd ${ }^{3}$. Na deze 'operationalisering' wordt in het tweede deel van dit hoofdstuk (differential) triple-entry accounting in verband gebracht met een aantal hiermee verwante ontwikkelingen zoals matrix-accounting en de 'events accounting'.

\footnotetext{
'Overigens werd dit model beloond met de Australian Design Award.

${ }^{2}$ Merkwaardig is overigens dat Carmichael (1987:26) de gevolgen van automatisch doorboeken nict doorziet wanneer het gaat om interne controle. Hij beweert dat het totaal van een grootbockrekening en het totaal van de controlerende rekening in het hieraan refererende subgrootboek, aan elkaar gelijk dienen te zijn. Los van de vraag of in een geautomatiseerde omgeving het onderscheid grootboek/subgrootboek nog wel relevant is, berust het "bijwerken' van het grootboek/ subgrootboek op eenmalige invoer. Derhalve is van een additionele inteme controle geen sprake.

${ }^{3}$ Momentum accounting is feitelijk een eerste stap richting differential triple-entry accounting. Om deze reden wordt het door integratie van beide systemen verkregen nieuwe systeem in het vervolg als zijnde een (differential) tripleentry accountingsystcem aangemerkt. Om te kunnen spreken van een (differential) triple-entry accountingsysteem is deze integratie evenwel geen voorwaarde.
} 


\subsection{De CLM-case}

In deze paragraaf wordt een gestileerd voorbeeld uitgewerkt van een computer-verhuurbedrijf: $\mathrm{CLM}^{4}$. De ten aanzien van dit bedrijf opgetreden transacties zullen zowel volgens het dubbel boekhoudmodel (paragraaf 8.3 ) als volgens het drie-dimensionale model (paragraaf 8.4 ) worden uitgewerkt. Langs deze weg kan op efficiënte wijze een vergelijkende analyse plaatsvinden (paragraaf 8.5 ). Het betreffende voorbeeld heeft tevens gediend als basis voor het experiment inzake het nut van differential triple-entry accounting (zie hoofdstuk 9).

\section{Computer Leasing Maatschappij (CLM)}

\section{Achtergrondinformatie}

Computer Leasing Maatschappij is een rechtspersoonlijkheid bezittende vennootschap die als bedrijfsactiviteit heeft het verhuren van computers met bijbehorende aanverwante apparatuur. De onderneming is opgericht per 1-1-1991 en is gevestigd te Utopia (een klein subtropisch eiland in het midden van de Stille Zuidzee). De geldeenheid welke wordt gehanteerd in Utopia, is de UCU ('Utopian Currency Unit'). Deze geldeenheid wordt weergegeven met de ISO-code Û. Mede door het stringente monetair beleid van de Utopese regering, is de inflatie steeds nihil. Utopia kent bovendien geen belastingen.

CLM is ontstaan uit een bedrijfsfusie met een tweetal, in moeilijkheden verkerende, verhuurvennootschappen. Dit waren TMG en SEG. Bij deze fusie werden, voorzover als mogelijk, de gezonde delen van de twee vennootschappen ondergebracht bij CLM. Bij CLM zijn 38 werknemers in dienst. Het bestuur wordt gevormd door een drietal directeuren, zijnde de directeur Technische Zaken \& Onderhoud, de directeur Commerciële Zaken en tenslotte de directeur Financieel-Economische Zaken. De verhuur van de computers cum annexis vindt plaats in de vorm van operational lease op basis van jaarcontracten. Er zijn geen boeteclausules opgenomen in deze jaarcontracten. Dit impliceert dat er per het einde van elk (contract)jaar vrije opzegging kan plaatsvinden, zonder enige directe financiële consequenties.

Bij de oprichting van CLM zijn a pari aandelen geplaatst en volgestort voor een bedrag van Ũ 300.000 .000 . In verband met het overgenomen personeel is aan goodwill Ũ 50.000 .000 betaald. Behalve het personeel heeft CLM van TMG en SEG de uitstaande vorderingen tegen het nominale bedrag van Ū 180.000 .000 overgenomen.

In 1991 en 1992 hebben zich ten aanzien van CLM de volgende financiële feiten voorgedaan:

1991

1. Oprichting van de vennootschap. Plaatsing en volstorting van het aandelenvermogen ad UU 300.000 .000 . Betaling van $\tilde{U} 180.000 .000$ voor overgenomen vorderingen en Ü 50.000.000 voor goodwill.

${ }^{4}$ De gegevens uit deze case zijn voor een zeer beperkt deel gebaseerd op Ijiri (1989:4). 
2. Op 1 januari is een obligatielening van $U$ 100.000 .000 afgesloten. De looptijd van de lening is 3 jaar. De op de lening te betalen rente is $10 \%$ per jaar. Zie ook onderdeel 9.

3. Op 1 januari is een aantal computers aangeschaft voor Ũ 360.000 .000 . De geschatte economische gebruiksduur van deze computers is 36 maanden. De restwaarde hierna wordt op nihil gesteld.

4. De onder 2 bedoelde computers zijn per 1 januari verhuurd voor Ũ 30.000 .000 per maand. De huur dient per het eind van iedere maand te worden voldaan. Alle huur is in 1991 ontvangen.

5. De maandelijkse afschrijving op de computers onder 2 bedraagt Ũ 10.000 .000 .

6. De onderhoudskosten op de computers onder 2 bedragen per kwartaal Ú 24.500.000. Deze kosten zijn in 1991 volledig voldaan.

7. Per het einde van elke maand wordt een dividend van Ũ 3.000 .000 uitbetaald. Dit is $12 \%$ per jaar van het nominaal eigen vermogen.

8. De afschrijving op de goodwill bedraagt Ũ 10.000 .000 per jaar.

9. Op 31-12 is over 1991 U 10.000 .000 aan rente betaald.

10. Van de over 1991 gerealiseerde winst wordt Ũ 86.000 .000 gereserveerd.

11. Van de uitstaande vorderingen staat per het eind van het jaar nog Ū 100.000.000 open. Er hebben zich geen wanbetalingen voorgedaan.

1992

1. Wegens het grote aantal klachten van gebruikers heeft het management besloten per 1-1-1992 het onderhoud te intensiveren. De kosten die hiermee verband houden bedragen Ũ 32.000 .000 op jaarbasis. Zie ook onderdeel 10.

2. Op 1 juli is voor U 400.000 .000 in nieuwe computers geînvesteerd. De geschatte gebruiksduur van deze computers is 40 maanden. De restwaarde wordt op nihil gesteld.

3. De onder 2 bedoelde nieuwe computers zijn eveneens per 1 juli verhuurd voor ũ 28.000.000 per maand. Zie ook onderdeel 5. De geschatte toename van de onderhoudskosten bedraagt Ũ 40.000 .000 op jaarbasis. Deze kosten zijn steeds per het begin van elk jaar verschuldigd. Voor het onderhoud over de tweede helft van 1992 dient, vanwege de eerste (intensieve) controle, het volle bedrag ad $\tilde{U}$ 40.000 .000 te worden betaald.

Zie ook onderdeel 10. Voor de extra afschrijvingen zie onderdeel 7.

4. In verband met het op de markt brengen van de nieuwe computers is het bedrijf genoodzaakt de leasetermijnen van de 'oude' computers met ingang van 1 juli te verlagen van Ũ 30.000 .000 per maand tot Ũ 24.000 .000 per maand.

Zie ook onderdeel 5 en 9.

5. Ontvangen aan huur Ũ 486.500 .000 .

Zie ook onderdeel 9 en onderdeel 17.

6. Op 1 juli is in verband met de financiering van de uitbreiding van het netwerk een onderhandse lening afgesloten voor Ū 100.000.000. De looptijd van deze lening is 3 jaar tegen een rente van $12 \%$ op jaarbasis. De rente wordt halfjaarlijks bij achterbetaling voldaan.

Zie ook onderdeel 8.

7. De maandelijkse afschrijving op de verhuurde computers is van $1-1 \mathrm{t} / \mathrm{m}$ 30-6 U 10.000 .000 per maand en vanaf 1-7 Ũ 20.000 .000 per maand.

8. Op 31 december is $\tilde{U} 16.000 .000$ aan rente betaald (Ũ 10.000 .000 op de obligatielening en Ũ 6.000 .000 op de onderhandse lening). 
9. Begin oktober is een nieuwe concurrent op de markt gekomen, waarbij werd ingeschat dat de omzet in het laatste kwartaal 1992 Û 2.500.000 zou achter blijven bij de voor dat kwartaal begrote omzet. Het management ging er van uit dat dit omzet-effect blijvend van aard zou zijn. De geschatte kostenreductie in het laatste kwartaal in 1992 ten gevolge van de verminderde omzet door het op de markt komen van de eerder genoemde nieuwe concurrent bedraagt Ũ 500.000 . Ook dit kosten-effect achtte het management blijvend van aard.

Zie ook onderdeel 10 en 17.

10. Aan onderhoudskosten is Ũ 169.500 .00 betaald.

11. Per 1 januari is het maandelijkse dividend verhoogd tot U 5.000 .000 , zijnde op jaarbasis $20 \%$ van het nominaal ingebrachte eigen vermogen. Het totale dividend is in 1992 uitbetaald.

12. De afschrijving op de goodwill bedraagt Ũ 10.000 .000 per jaar.

13. Van de over 1992 gerealiseerde winst wordt Ũ 25.000.000 gereserveerd.

14. Voor reorganisatiekosten is $\mathrm{U} 26.000 .000$ betaald. Het betreft hier een eenmalige kostenpost.

15. Eind 1992 wordt het personeel een loonstijging van $10 \%$ toegezegd, ingaand per 1-1-1993. Als gevolg hiervan stijgen de loonkosten volgend jaar van

Ũ 120.000.000 naar Ũ 132.000.000 per jaar. Deze loonkosten maken onderdeel uit van de totale onderhoudskosten.

16. Van de uitstaande vorderingen staat per het eind van het jaar nog Ũ 60.000 .000 open.

17. Per eind 1992 blijkt alsnog dat een deel van de voor 1992 begrote omzet niét is gehaald. Het betreffende bedrag ad Ũ 3.000 .000 wordt toegeschreven aan de onder 9 bedoelde nieuwe concurrent. Het management is van mening dat het verlies van dit deel van de markt structureel van aard is. De daling van de onderhoudskosten was conform de bij onderdeel 9 uitgesproken verwachting.

\subsection{Gegevensverwerking bij CLM in een dubbel boekhoudmodel}

De gevolgen op jaarbasis van de in de vorige paragraaf genoemde financiële feiten voor de financiële positie van CLM kunnen bij toepassing van dubbel boekhouden als volgt in de vorm van journaalposten worden opgetekend.

Op basis van dit journaal (zie pagina 175 en 176) is vervolgens voor CLM een financieel eindverslag over 1992 opgemaakt. In de toelichting op dit verslag zijn aanvullende gegevens opgenomen met betrekking tot de financiële positie van de vennootschap. 
Journaal 1991 (bedragen $\times$ Ũ 1.000.000)

debet credit

1. Liquide middelen 70 Goodwill 50 Vorderingen 180 Aan Aandelenvermogen

300

2. Liquide middelen 100 Aan Obligatielening

3. Computers

360

Aan Liquide middelen

360

4. Liquide middelen

360

Aan Huuropbrengsten

360

5. Afschrijvingskosten computers

120 Aan Computers

120

6. Onderhoudskosten

98

Aan Liquide middelen

7. Netto winst

Aan Liquide middelen

36

36

8. Afschrijvingskosten goodwill

10

Aan Goodwill

9. Rentelasten

Aan Liquide middelen

10

10. Netto winst

86

Aan Winstreserves

86

11. Liquide middelen

$80^{\circ}$

Aan Vorderingen

80

(180 - 100)

Totaal

$1560 \quad 1560$ 
Journaal 1992 (bedragen $\times$ Ũ 1.000.000)

1. Geen journaalpost

2. Computers

Aan Liquide middelen

debet credit

400

400

3. Geen journaalpost

4. Geen journaalpost

5. Liquide middelen

$486.5^{\circ}$

Aan Huuropbrengsten

$(6 \times 30+6 \times 24+6 \times 28-2.5-3)$

486.5

6. Liquide middelen

Aan Onderhandse lening

100

100

7. Afschrijvingskosten computers

180

Aan Computers

8. Rentelasten

Aan Liquide middelen

9. Geen journaalpost

10. Onderhoudskosten

$169.5^{\circ}$

Aan Liquide middelen

$(98+32+40-0.5)$

169.5

11. Netto winst

60

Aan Liquide middelen

60

12. Afschrijvingskosten goodwill

Aan Goodwill

13. Netto winst

Aan Winstreserves

25

14. Incidentele lasten en baten

Aan Liquide middelen

26

15. Geen journaalpost

16. Liquide middelen

$40^{\circ}$

Aan Vorderingen

(100 - 60)

17. Geen journaalpost

Totaal

$1513 \quad 1513$ 
Financieel Verslag Computer Leasing Maatschappij 1992

\begin{tabular}{|l|r|r|l|r|r|}
\hline $\begin{array}{l}\text { Balans per 31-12 } \\
\text { (x Ũ 1.000.000) }\end{array}$ & 1992 & 1991 & & 1992 & 1991 \\
\hline & 30 & 40 & $\begin{array}{l}\text { Eigen vermogen: } \\
\text { - aandelenvermogen }\end{array}$ & 300 & 300 \\
Goodwill & 460 & 240 & -winstreserves & 111 & 86 \\
Computers & 60 & 100 & $\begin{array}{l}\text { Vreemd vermogen: } \\
\text {-obligaties }\end{array}$ & 100 & 100 \\
Vorderingen & 61 & 106 & $\begin{array}{l}\text {-onderhandse } \\
\text { lening }\end{array}$ & 100 & 0 \\
Liquide mid. & 611 & 486 & & 611 & 486 \\
\hline
\end{tabular}

\begin{tabular}{|l|r|r|}
\hline $\begin{array}{l}\text { Resultatenrekening over } 1992 \\
(\times \text { U 1.000.000) }\end{array}$ & 1992 & 1991 \\
\hline & 486,5 & 360 \\
\hline Netto-opbrengsten uit verhuur & 169,5 & 98 \\
Onderhoudskosten & 180 & 120 \\
Afschrijvingskosten computers & 137 & 142 \\
\hline Bruto-verhuurresultaat & 16 & 10 \\
Rentelasten & 10 & 10 \\
\hline Afschrijvingskosten goodwill & 111 & 122 \\
\hline Netto-winst uit verhuur & 26 & 0 \\
\hline Incidenteel verlies & 85 & 122 \\
\hline Netto-winst & 60 & 36 \\
\hline Uitgekeerd dividend & 25 & 86 \\
\hline Toevoeging aan winstreserves & 85 & 122 \\
\hline Verdeelde netto-winst & & \\
\hline
\end{tabular}




\section{Toelichting}

\section{Balans}

\section{Goodwill}

Deze post betreft de betaalde goodwill op het bij de fusie van de vennootschappen TMG en SEG overgenomen personeel. Op het betaalde bedrag (Ũ 50.000.000) zijn de cumulatieve afschrijvingen in mindering gebracht.

\section{Computers}

Deze post omvat de door CLM aangeschafte computers die momenteel zijn verhuurd en als zodanig bij de klanten aanwezig zijn. De gehele voorraad computers is, evenals in 1991, voor verhuur in gebruik. Gewaardeerd wordt tegen historische kostprijs minus afschrijvingen op basis van de lineaire afschrijvingsmethode. Op 1-7-1992 is voor Ũ 400.000 .000 in nieuwe computers geïnvesteerd. Deze zullen worden afgeschreven over een periode van 40 maanden. Voor de computers die aan het begin van het jaar reeds in gebruik waren, resteert op 31-12-1992 nog een (economische) levensduur van 1 jaar.

\section{Vorderingen}

Deze post bevat de kortlopende vorderingen. Deze zijn gewaardeerd tegen nominale waarde. Eventueel oninbare vorderingen worden verrekend met de (bruto)opbrengsten uit verhuur van computers cum annexis.

\section{Liquide middelen}

Deze post omvat de kasmiddelen en de direct opeisbare tegoeden bij de bank.

\section{Eigen Vermogen}

Het aandelenvermogen omvat de nominale waarde van de volgestorte aandelen. $\mathrm{Er}$ heeft in 1992 geen uitbreiding van het aandelenvermogen plaatsgevonden. De winstreserves zijn in 1992 slechts gewijzigd door dotatie van de niét-uitgekeerde winst over 1992. Met de aandeelhouders is overeengekomen dat met ingang van 1992 de jaarlijkse dividenduitkering (het dividendpercentage) zal worden verhoogd van $12 \%$ naar $20 \%$.

\section{Vreemd Vermogen}

Het vreemd vermogen bestaat uitsluitend uit leningen op lange termijn. Op de obligatielening heeft geen aflossing plaatsgevonden. Het betreft een ineens aflosbare obligatielening met ingang van 1-1-1991, tegen $10 \%$ rente per jaar, met een looptijd van 3 jaar. De rente dient jaarlijks te worden betaald, steeds per het einde van ieder jaar.

In verband met de uitbreidingsinvestering in computers is per 1-7-1992 een ineens aflosbare onderhandse lening van Ũ 100.000.000,- afgesloten met een looptijd van 3 jaar. Er is een rentevergoeding overeengekomen van $12 \%$ per jaar. De rente dient halfjaarlijks te worden betaald, steeds per het einde van ieder halfjaar. 


\section{Resultatenrekening}

Netto-opbrengsten uit verhuur

Deze post bevat de bruto-opbrengsten uit de verhuur van computers cum annexis, minus de oninbare vorderingen. In 1992 hebben zich evenals in 1991 geen oninbare vorderingen voorgedaan. De stijging in de opbrengsten uit de computerverhuur is ontstaan als gevolg van de uitbreiding van de leasecapaciteit per 1-7-1992. De per deze datum ontvangen computers werden meteen verhuurd tegen een maandelijkse leasetermijn van Ũ 28.000 .000 in totaal. Door in gebruik name van de nieuwe computers bleek het noodzakelijk de leasetarieven op de reeds verhuurde computers te verlagen. Deze tarieven werden per 1-7-1992 verlaagd van in totaal Ũ 30.000 .000 naar Ũ 24.000 .000 per maand. De concurrentie in de leasemarkt heeft zich in 1992 verhevigd. Ten gevolge hiervan is de omzet over 1992 zo'n Ũ 5.500 .000 achtergebleven bij de voor 1992 genormeerde omzet ad Ũ 492.000 .000 . Het bestuur gaat er van uit dat dit effect structureel is.

\section{Onderhoudskosten}

Deze post bevat alle kosten die kunnen worden toegerekend aan de onderhoudsactiviteiten van de verhuurde computers cum annexis. Als gevolg van een groot aantal klachten van gebruikers heeft het bestuur besloten tot een permanente intensivering van de onderhoudsactiviteiten per 1-1-1992. Dit besluit alsmede het onderhoud aan de uitbreiding van het computernetwerk leidde tot een structurele stijging van de kosten voor onderhoud van U 72.000 .000 ten opzichte van 1991. Alle kosten verbonden aan de onderhoudsactiviteiten zijn regelmatig over het jaar verspreid.

De kostenreductie die met het achterblijven van de verhuuromzet wegens concurrentie gepaard ging, bedroeg Ũ 500.000 . Het bestuur gaat er van uit dat ook dit effect structureel is.

\section{Afschrijvingskosten computers}

De afschrijving op de verhuurde computers vindt plaats volgens de lineaire methode, uitgaande van de historische kostprijs en de geschatte economische gebruiksduur. Als gevolg van de snelle ontwikkelingen in de computerbranche wordt de restwaarde steeds op nihil gesteld.

Rentelasten

Rentelasten worden uitsluitend betaald over langlopende leningen. De rentevergoeding op de obligatielening is $10 \%$ op jaarbasis. De rentevergoeding op de onderhandse lening bedraagt $12 \%$ op jaarbasis.

\section{Afschrijving op goodwill}

De afschrijving op de goodwill vindt plaats volgens de lineaire methode, uitgaande van de historische kostprijs. Afgeschreven wordt over een periode van 5 jaar.

\section{Incidenteel verlies}

Het bestuur concludeerde begin 1992 dat om op lange termijn optimaal op de ontwikkelingen op de computerleasemarkt te kunnen inspelen en aldus een strategisch sterke positie te kunnen behouden, het absoluut noodzakelijk was dat de bestaande organisatie werd gewijzigd. Besloten werd de functionele organisatiestructuur te vervangen door een 
8 Operationalisering concept triple-entry en momentum accounting

meer gedecentraliseerde divisiestructuur. De reorganisatie werd aldus in 1992 geheel doorgevoerd. De kosten verbonden aan deze reorganisatie bedroegen Ũ 26.000.000.

\section{Algemeen}

In december 1992 werd met de vakbonden en werknemers overeengekomen de loonontwikkelingen in de branche te volgen. Als gevolg hiervan vindt met ingang van 1-11993 een loonstijging van $10 \%$ plaats voor het computeronderhoudspersoneel. Dit leidt tot een stijging van de jaarlijkse loonkosten van Ũ 120.000.000 naar Ũ 132.000.000. Deze loonkosten maken deel uit van de totale onderhoudskosten.

Voor 1993 wordt verwacht dat als gevolg van groot onderhoud gemiddeld slechts $90 \%$ van de capaciteit in gebruik zal zijn.

Voor dit onderhoud is nog geen voorziening getroffen. Naar alle waarschijnlijkheid zal als gevolg van dit groot onderhoud de opbrengst uit verhuur eenmalig dalen met $\bar{U}$ 62.400.000,- en zullen er incidenteel extra onderhoudskosten worden gemaakt voor het bedrag van Ũ $27.750 .000,-$.

In het aldus opgemaakte CLM-jaarverslag is een aantal gegevens opgenomen dat we normaliter niet in een (extern) jaarverslag tegenkomen. Deze gegevens zijn evenwel toegevoegd opdat in beide situaties, dubbelvoudig accounting en (differentieel) drievoudig accounting, een vergelijkbare beslissingsbasis ontstaat. Hierdoor is het bijvoorbeeld mogelijk een vergelijking te maken van de kwaliteit van de winstvoorspellingen in beide situaties (zie het experiment zoals dat in hoofdstuk 9 zal worden besproken).

Wanneer een winstvoorspelling voor CLM over 1993 wordt gebaseerd op het hiervoor verstrekte jaarverslag, is een aantal aanvullende gegevensbewerkingen alsnog noodzakelijk. Een model-protocol van een dergelijke bewerking zou er als volgt kunnen uitzien: 
Tabel 8.1 Protocol winstvoorspelling 1993 (bedragen x 1 miljoen).

\begin{tabular}{|c|c|}
\hline nettowinst 1992 & 85 \\
\hline + incidentele verlies 1992 & 26 \\
\hline $\begin{array}{l}\text { + toename huuropbrengsten in 1993: } \\
6 \times 28 \text { (nieuwe computers) } \\
-6 \times 6 \text { (daling verhuur oude computers) } \\
-16.5 \quad \text { (daling verhuur als gevolg van concurrentie)* } \\
-62.4 \quad \begin{array}{l}\text { (eenmalige daling verhuur als gevolg van groot } \\
\text { onderhoud) }\end{array} \\
\end{array}$ & 53,1 \\
\hline $\begin{array}{l}\text { - toename onderhoudskosten in 1993: } \\
-0,5 \text { (daling als gevolg van omzetdaling)** } \\
+12 \text { (toename als gevolg van loonsverhoging) } \\
+27,75 \text { (eenmalige toename als gevolg van groot onderhoud) }\end{array}$ & $-38,25$ \\
\hline $\begin{array}{l}\text { - toename afschrijvingskosten in 1993: } \\
6 \times 10=\end{array}$ & -60 \\
\hline $\begin{array}{l}\text { - toename rentelasten onderhandse lening in } 1993 \text { : } \\
6 / 12 \times 12 \% \text { van } 100\end{array}$ & -6 \\
\hline begrote winst 1993 & 59,85 \\
\hline
\end{tabular}

*In het laatste kwartaal van 1992 was de negatieve invloed van de concurrentie op de omzet in totaal 5.5. Dit is op jaarbasis 22 en geeft derhalve een verwachte toename van de daling van de omzet voor 1993 van (22. $5.5=) 16.5$.

"In het laatste kwartaal van 1992 was de positieve invloed van de concurrentie op de onderhoudskosten 0.5 . Dit is op jaarbasis 2 en geeft derhalve een verwachte toename in de daling van de onderhoudskosten voor 1993 $\operatorname{van}(2-0.5=) 1.5$.

Bij (differential) triple-entry accounting is een belangrijk deel van de hiervoor ten behoeve van de winstvoorspelling uitgevoerde bewerkingen, formeel gesystematiseerd. In de volgende paragraaf wordt dit uiteengezet.

\subsection{Gegevensverwerking in een drie-dimensionaal accountingmodel}

Behalve dat aan het overigens indrukwekkende werk van ljiri de boekingsregels ontbreken die nodig zijn voor het intracomptabel implementeren van het triple-entry concept, ontbreekt vervolgens ook een integraal administratief model waarin de derde dimensie gestalte kan worden gegeven. In deze paragraaf worden voor genoemde boekingsregels en administratief model de contouren uiteen gezet. 


\subsubsection{Inleiding}

In paragraaf 7.2 zijn de boekingsregels uiteengezet zoals die gelden in een dubbel boekhoudstelsel bij toepassing van de twee-rekeningen reeksen-theorie. $\mathrm{Bij}$ toepassing van een dubbel boekhoudstelsel worden evenwel bepaalde vaak belangrijke financiële feiten niét opgetekend. Wanneer bijvoorbeeld van de bank bericht wordt ontvangen dat de rente op het uitstaande deposito ad $f 500 \mathrm{mln}$ is verlaagd van $7 \%$ naar $6 \%$, wordt hiervan géén aantekening gemaakt (hetgeen wordt gerechtvaardigd met een verwijzing naar het realisatie-principe). Toch staat met het bericht van de rentedaling onomwonden vast dat de winstcapaciteit van de onderneming is verslechterd. Wanneer vervolgens het betreffende deposito wordt omgezet in te verhuren onroerend-goed met een verwacht huurrendement van $12 \%$ per jaar, wordt enkel de verandering in de samenstelling van het eigen vermogen opgetekend. Dit komt tot uitdrukking in de journaalpost:

\section{Onroerend goed $f 500 \mathrm{mln}$}
Aan Deposito
f $500 \mathrm{mln}$

De met deze investering veranderde winstcapaciteit van het eigen vermogen (6\% per jaar wordt $12 \%$ per jaar) wordt niét geadministreerd. Gevolg is een ónvolledige beschrijving van het verloop in de financiële bedrijfstoestand en derhalve van de financiële gevolgen van de door het management in een bepaalde verslagperiode ondernomen activiteiten.

Naast veranderingen in samenstelling en/of omvang van het eigen vermogen worden bij differential triple entry accounting ook oorzakelijke winstmutaties geadministreerd. Via het administreren van winstkrachten kan aan de administratie een (systematisch) overzicht worden ontleend van de achterliggende factoren welke veranderingen in het periodieke resultaat teweeg hebben gebracht. De geldelijke effecten van de opgetreden winstkrachten dienen hiertoe te worden uitgedrukt in de zelfde tijddimensie als waarin de resultatenrekening wordt opgemaakt, dat wil zeggen: guldens over een bepaalde periode (stroomgrootheden). Het aldus beschikbare overzicht dat de oorzaken opsomt van mutaties in het van periode tot periode gerealiseerde resultaat, zal ik aanduiden als winst-mutatiestaat (of 'action statement').

In momentum accounting worden oorzaken van veranderingen in de winstsnelheid van het eigen vermogen ('income momentum') geadministreerd. De winstsnelheid zoals die per een bepaald moment bestaat, blijkt uit de winstsnelheids-staat (of 'momentum statement'). Oorzaken van mutaties in de winstsnelheid worden met hun geldelijke effecten vastgelegd op de winstsnelheids-mutatiestaat ('impulse statement'). 
In principe is het vanwege de verschillende tijddimensies (en daarmee verbonden verschillen in maateenheden) onmogelijk een systeem van momentum accounting te integreren in een systeem van differential triple-entry accounting. Waar in differential triple-entry accounting wordt gewerkt met guldens, wordt in momentum accounting gewerkt met guldens per periode. Maar door gebruik te maken van grootboekrekeningen voor ongerealiseerde winstsnelheden, kan volledige afstemming worden bereikt tussen het momentum accountingsysteem en het systeem van differential triple-entry accounting. Op deze wijze kunnen de voordelen van beide systemen worden gebruikt voor het verantwoorden van de verhoogde administratiekosten.

Het in paragraaf 8.4.2 te bespreken administratieve systeem is te beschouwen als een integratie van momentum en differential triple-entry accounting.

Een winst-mutatiestaat geeft een verklaring voor de verandering in het winstcijfer van enige verslagperiode ten opzichte van de winst over de vorige verslagperiode. Het eigen vermogen op enig tijdstip $t_{2}$ kan aldus langs drie wegen (dimensies) worden bepaald:

1. Uit de samenstelling van het eigen vermogen op $t_{2}$. eigen vermogen per $t_{2}=$ beschikbare activa per $t_{2}$ - vreemd vermogen per $t_{2}$

2. Via de administratie van de in de periode $t_{2}-t_{1}$ gerealiseerde winst, dit is de verandering in de omvang van het eigen vermogen.

eigen vermogen per $t_{2}=$ eigen vermogen per $t_{1}+$ winst over de periode $t_{2}-t_{1}-$ winstuitkering in de periode $t_{2}-t_{1}+/$ - stortingen/onttrekkingen in de periode $t_{2}-t_{1}$.

3. Via de geadministreerde effecten van winstkrachten. eigen vermogen per $t_{2}=$ eigen vermogen per $t_{1}+$ winst over de periode $t_{1}-t_{0}+t-$ winstmutatie in de periode $t_{2}-t_{1}$ - winstuitkering in de periode $t_{2}-t_{1}+/$ - stortingen/onttrekkingen in de periode $t_{2}-t_{1}$. In deze laatste benadering is duidelijk dat bij de berekening van het eind eigen vermogen per $t_{2}$ in eerste instantie wordt aangenomen dat de in de vorige periode $t_{1}-t_{0}$ gerealiseerde winst ook in de actuele periode $t_{2}-t_{1}$ kan worden gerealiseerd ${ }^{5}$. Immers de winst over de periode $t_{1}-t_{0}$ tezamen met de winstmutatie in de periode $t_{2}-t_{1}$ geeft de winst over de periode $t_{2}-t_{1}$.

Een winst-mutatiestaat kan zowel extracomptabel als intracomptabel worden samengesteld. In de toelichting op de balans en resultatenrekening alsmede (en vooral) in het directieverslag kunnen een groot aantal (vaak niét-kwantitatief gespecificeerde) gegevens worden aangetroffen die betrekking hebben op gerealiseerde winstkrachten. Te denken valt aan gegevens over veranderde rentepercentages, arbeidsproduktiviteit, bedrijfsefficiency, overnames, valutaire invloeden, overheidsmaatregelen, marktondersteuning, marktaandelen, ziekteverzuim, wijziging in afschrijvingen, personeelsbestand, investe-

\footnotetext{
${ }^{5}$ Dit is een van de postulaten die binnen momentum accounting wordt gehanteerd (zie hiervoor ook paragraaf 7.5.5).
} 
ringen, orderportefeuille, invloed van de concurrentie, grondstofprijzen, wijzigingen in voorzieningenbeleid, conjuncturele invloeden, bezettingsgraden en nieuwe deelnemingen. Een buitenstaander kan op basis van deze (niet-systematisch gegroepeerde) gegevens proberen een sluitende winst-mutatiestaat samen te stellen. Hierbij wordt hij echter gesteld voor (te veel) niet-oplosbare schattings- en toerekeningsproblemen. Wat is bijvoorbeeld het precieze netto-effect van een stijging van de Dollar met 20 cent of een daling van het ziekteverzuim met $1 \%$ op het winstcijfer van Philips? Anders ligt dit bij het betreffende bedrijfsmanagement. Het kan als een tak van het management worden gezien uitspraken te doen over de verwachte effecten op het bedrijfsresultaat van bijvoorbeeld rente-ontwikkelingen of programma's voor hogere arbeidsproduktiviteit. Deze (te funderen) uitspraken over de gevolgen van dergelijke ontwikkelingen voor de toekomstige winstpositie van de onderneming kunnen in het (drie-dimensionale) accountingsysteem (in de derde dimensie) worden vastgelegd. Op basis van deze administratie kan de winstmutatiestaat intracomptabel worden opgemaakt zodat een sluitende verklaring beschikbaar is voor de verandering in het gegenereerde resultaat en de krachten die daaraan ten grondslag liggen.

In een aantal situaties zal pas ex-post kunnen worden vastgesteld dat bijvoorbeeld het verkoopresultaat is achter gebleven bij dat van het vorig jaar. In het geval het hier gaat om een materieel residu, zal een nadere analyse aan het licht moeten brengen wat de achterliggende oorzaken zijn. Vervolgens kan in de driedimensionale administratie van deze oorzaken alsnog aantekening worden gemaakt.

\subsubsection{Intracomptabele verwerking van de derde dimensie en de samenstelling van de winst-mutatiestaat}

In afwijking van Ijiri zal in deze paragraaf een administratief systeem worden besproken dat wordt gekenmerkt door een integratie van triple-entry en momentum accounting. Hierbij wordt het probleem van de tijddimensie opgelost door in het grootboek rekeningen aan te leggen voor de ongerealiseerde effecten van opgetreden winstkrachten (dit zijn contra-rekeningen). In dit systeem staat de administratie van de winstsnelheid centraal (de winstcapaciteit of 'income momentum') en de mutaties die in de winstsnelheid optreden ten gevolge van bepaalde winstkrachten. Ten gevolge van deze zogenaamde impulsen zal het periodieke resultaat verschillen (dit zijn de acties) en derhalve blijft overeind de derde, nieuwe dimensie: (oorzakelijke) winstmutaties. De aard van de winst-mutatiestaat die in dit systeem wordt opgesteld is feitelijk een combinatie van winst-mutatiestaat en winstsnelheids-staat.

Alhoewel in het geïntegreerde systeem de administratie van winstsnelheids-mutaties voorop staat, wordt het verkregen nieuwe, derde overzicht als 'winst-mutatiestaat' aangeduid omdat op dit overzicht op basis van de geadministreerde winstsnelheids-mutaties een 
oorzakelijke relatie wordt gelegd met betrekking tot het van periode tot periode gerealiseerde resultaat ${ }^{6}$.

Met betrekking tot de winstsnelheid van het eigen vermogen kunnen twee aspecten worden onderscheiden:

a. De realisatie ervan in bepaalde kosten en/of opbrengsten. Wanneer zich uitsluitend financiële feiten zoals hier bedoeld voordoen, zal de winst in de tijd gezien gelijk blijven.

b. Het ontstaan/toenemen en tenietgaan/afnemen ervan ten gevolge van winstkrachten (impulsen). Ten gevolge van deze krachten treden van tijd tot tijd veranderingen op in het winstcijfer.

Ten behoeve van de administratie in het grootboek van de winstsnelheids-effecten van winstkrachten dienen bij elke resultaatpost (minimaal) twee grootboekrekeningen te worden aangelegd:

1. Een controlerende winst-mutatierekening ${ }^{7}$ (voor de administratie van de realisatie van de income momentum).

Deze rekening geeft aan welk kosten- casu quo opbrengstbedrag in de lopende periode dient te worden gerealiseerd op basis van het per het begin van deze periode aanwezige 'momentum'. Dergelijke grootboekrekeningen kunnen worden genoemd ' $\mathrm{Te}$ realiseren huuropbrengsten', 'Te realiseren onderhoudskosten', 'Te realiseren rentelasten', enzovoort ${ }^{8}$. Afgezien van de omrekening in guldens per periode naar guldens voor de komende verslagperiode, komt het openen van deze rekeningen neer op het overschrijven van de posten en bijbehorende bedragen op het momentum statement per het begin van de betreffende periode.

Het hier bedoelde type grootboekrekeningen wordt ingevoerd in verband met het eerste postulaat in momentum accounting: de veronderstelling dat de in het verleden gecreëerde winstsnelheid van het eigen vermogen in de toekomst onveranderd zal blijven tot dat een winstkracht daarin verandering brengt (de veronderstelling van

\footnotetext{
${ }^{6}$ Indien deze toerekening achierwege wordt gelaten, is het aldus verkregen overzicht de winstsnelheids-mutatiestaat.

${ }^{7}$ Hier dient in principe van winstsnelheids-mutaticrekeningen te worden gesproken. Maar vanwege de aansluiting die in het geïntegrecrde systeem wordt gezocht tussen ontwikkeling in de income momentum en ontwikkelingen in het periodieke resultaat, worden deze rekeningen als 'winst-mutatierekeningen' aangeduid.

${ }^{8}$ Wanneer de bedragen van deze posten volgens de begroting overeenkomen met de bedragen op basis van de per het begin van de budgetperiode aanwezige momenta voor genoemde posten, dan kunnen de controlerende winstmutatierekeningen worden gelijkgesteld aan de in paragraaf 7.4 .2 besproken budgetrekeningen.
} 
constante winstsnelheid waardoor winstmutaties achterwege blijven). Dit betekent dan ook dat deze grootboekrekeningen in principe worden geopend met de bedragen van de vorige verslagperiode. Het zijn als het ware de 'budgetbedragen' voor de komende verslagperiode. De openingsbedragen ten aanzien van de (te realiseren) kosten staan in dit verband als 'positief' geadministreerd en de (te realiseren) opbrengsten als 'negatief'. Wanneer kosten casu quo opbrengsten in het verloop van de verslagperiode worden gerealiseerd, worden deze rekeningen als respectievelijk 'negatief' en 'positief' opgetekend (het betreft immers uiteindelijk een afname respectievelijk toename van het eigen vermogen; zie ook de bespreking van temporal triple-entry accounting in paragraaf 7.4.1). Via de administratie op deze controlerende winst-mutatierekeningen kan worden nagegaan of zich al dan niet een bepaalde winstkracht aan het oog van het management heeft onttrokken ${ }^{9}$. Is dit niét het geval, dan is het saldo van deze rekeningen per het einde van de verslagperiode steeds (nagenoeg) nihil. Deze rekeningen komen dan ook niét voor op de winst-mutatiestaat.

2. Een verklarende winst-mutatierekening ${ }^{10}$ (voor de administratie van mutaties in de income momentum en dus impulses).

Op deze rekening worden de gevolgen van veranderingen in de winstsnelheid van het eigen vermogen geadministreerd zoals die ten gevolge van bepaalde winstkrachten zijn opgetreden. Het betreft hier derhalve de rekeningen waarop achterliggende oorzaken van winstmutaties worden opgetekend. Deze rekeningen kunnen bijvoorbeeld worden genoemd 'Afname huuropbrengsten als gevolg van concurrentie', 'Toename onderhoudskosten als gevolg van nieuwe CAO', 'Toename rentekosten als gevolg van nieuwe lening', enzovoort ${ }^{11}$. De saldi van deze verklarende winst-mutatierekeningen worden op de winst-mutatiestaat opgenomen. Bij het optreden van een positieve winstmutatie wordt een positief bedrag ingevoerd terwijl bij het optreden van een negatieve winstmutatic een negatief bedrag wordt ingegeven. Het ultieme effect van deze winstkrachten is dat het eigen vermogen meer/minder toeneemt respectievelijk afneemt dan in de vorige verslagperiode.

${ }^{9}$ In dit geval is er sprake van een verschil tussen de geadministreerde 'actie' en feitelijk opgetreden 'winstmutatie'.

${ }^{10}$ Ook dit type rekeningen dient in principe als winstsnelheids-mutatierekeningen te worden aangemerkt. Zie de opmerking bij voetnoot 8 .

"Een systeem van zuiver 'momentum accounting' waarbij kosten- en opbrengsten-posten en de effecten van winstkrachten op de winstsnelheid worden gemeten in 'guldens per periode', kan op vergelijkbare wijze worden geïmplementeerd. Vanwege het verschil in masteenheid met het bestaande systeem ('guldens per periode' respectievelijk 'guldens') zal de ontwikkeling van de winstsnelheid evenwel in een sub-administratie moeten plaatsvinden. Door echter de effecten van winstkrachten op jaarbasis te administreren, kan desalniettemin de ontwikkeling van de 'income momentum' op jaarbasis worden vastgelegd. Hierbij dient het deel van de winstkrachten dat zich in de verslagperiode waarin deze krachten zich manifesteren niet tot realisatie zal komen, als 'ongerealiseerd' te worden verantwoord. Deze ongerealisecrde impuls betekent actie in de volgende verslagperiode. Bij de opstelling van de winst-mutatiestaat zal dit blijken. 
Wanneer een in een bepaalde verslagperiode opgetreden winstkracht zich in de betreffende periode nog niet (volledig) in winst heeft gemanifesteerd, dient ten behoeve van de afstemming van de resultatenrekening op de winst-mutatiestaat rekening te worden gehouden met deze ongerealiseerde winstkracht. In de trebit-kolom wordt in dit verband een ongerealiseerde positieve winstkracht als 'negatief' ingevoerd als zijnde een boekhoudkundige correctie op de eerder geboekte positieve winstmutatie. Een ongerealiseerde negatieve winstkracht wordt als 'positief' ingegeven, zijnde een vermindering van een eerder geboekte negatieve winstmutatie. ${ }^{12}$

Voor het verwerken van de financiële feiten wordt het journaal uitgebreid met een derde kolom: een trebitkolom. In deze kolom worden de hiervoor onderscheiden twee typen van rekeningen geadministreerd. Voorbeelden van financiële feiten waarvan de gevolgen in de trebitkolom worden opgetekend, zijn: het verkopen van bestaande produkten (=realisatie bestaand momentum), het maken van onkosten (=realisatie bestaand momentum), het op de markt brengen van een nieuw produkt (=positieve impuls), het toetreden van een nieuwe concurrent in een bestaande markt (=negatieve impuls), het verhogen van de produktie-efficiency (=positieve impuls) en een algemene verlaging van de rentevoet (=negatieve impuls ten aanzien van spaartegoeden en positieve impuls ten aanzien van opgenomen gelden zonder rentefixatie).

Gezien het voorgaande kunnen de boekingsregels in de hier gehanteerde vorm van een (differentiële) drie-dimensionale administratie bij toepassing van de drie-rekeningen reeksen-theoric als volgt worden geformuleerd:

1. Een rekening van een vermogensbestanddeel wordt in de debetkolom met een positief getal ingevoerd wanneer het eigen vermogen toencemt respectievelijk in de debetkolom met een negatief getal ingevoerd wanneer het eigen vermogen afneemt.

2. Een vermogensrekening wordt in de creditkolom met een positief getal ingevoerd wanneer het eigen vermogen toeneemt respectievelijk in de creditkolom met een negatief getal ingevoerd wanneer het eigen vermogen afneemt.

3. Een winst-mutatierekening wordt in de trebitkolom met een positief getal ingevoerd wanneer het eigen vermogen toeneemt respectievelijk in de trebitkolom met een negatief getal ingevoerd wanneer het eigen vermogen afneemt.

Conform tabel 7.1 kunnen bovenstaande boekingsregels als volgt nader worden gedetailleerd (zie tabel 8.2). Hierbij hebben respectievelijk positieve en negatieve winst-mutatierekeningen betrekking op respectievelijk positieve en negatieve winstkrachten.

\footnotetext{
${ }^{12}$ De hier onder 1 en 2 aangeduide nieuwe grootboekrekeningen kunnen ook worden genoemd 'te realiseren winsten verliesrekeningen' respectievelijk 'verklarende winst- en verliestekeningen'.
} 
Tabel 8.2 Gedetailleerde boekingsregels bij differential triple-entry accounting.

\begin{tabular}{|c|c|c|c|}
\hline & $\begin{array}{l}\text { mutatie in } \\
\text { betreffende } \\
\text { post }\end{array}$ & $\begin{array}{l}\text { mutatie in } \\
\text { het eigen } \\
\text { vermogen }\end{array}$ & $\begin{array}{l}\text { Lolorn- } \\
\text { aantekening }\end{array}$ \\
\hline $\begin{array}{l}\text { 1a.positief vermogensbestanddeel } \\
\text { (bijvoorbeeld kas) }\end{array}$ & $\begin{array}{l}\text { Toename } \\
\text { Afname }\end{array}$ & $\begin{array}{l}\text { Toename } \\
\text { Afname }\end{array}$ & $\begin{array}{l}\text { Debet + } \\
\text { Debet - }\end{array}$ \\
\hline $\begin{array}{l}\text { lb.negatief vermogensbestanddeel } \\
\text { (bijvoorbeeld crediteuren) }\end{array}$ & $\begin{array}{l}\text { Toename } \\
\text { Afname }\end{array}$ & $\begin{array}{l}\text { Afname } \\
\text { Toename }\end{array}$ & $\begin{array}{l}\text { Debet - } \\
\text { Debet + }\end{array}$ \\
\hline $\begin{array}{l}\text { 2a.positieve vermogensrekening } \\
\text { (bijvoorbeeld huuropbrengsten) }\end{array}$ & $\begin{array}{l}\text { Toename } \\
\text { Afname }\end{array}$ & $\begin{array}{l}\text { Toename } \\
\text { Afname }\end{array}$ & $\begin{array}{l}\text { Credit + } \\
\text { Credit - }\end{array}$ \\
\hline $\begin{array}{l}\text { 2b.negatieve vermogensrekening } \\
\text { (bijvoorbeeld loonkosten) }\end{array}$ & $\begin{array}{l}\text { Toename } \\
\text { Afname }\end{array}$ & $\begin{array}{l}\text { Afname } \\
\text { Toename }\end{array}$ & $\begin{array}{l}\text { Credit - } \\
\text { Credit }+\end{array}$ \\
\hline $\begin{array}{l}\text { 3a.controlerende positieve winst- } \\
\text { mutatierekening } \\
\text { (bijvoorbeeld te realiseren ver- } \\
\text { koopopbrengsten) }\end{array}$ & $\begin{array}{l}\text { Toename } \\
\text { Afname }\end{array}$ & $\begin{array}{l}\text { Afname } \\
\text { Toename }\end{array}$ & $\begin{array}{l}\text { Trebit - } \\
\text { Trebit }+\end{array}$ \\
\hline $\begin{array}{l}\text { 3b.controlerende negatieve winst- } \\
\text { mutatierekening } \\
\text { (bijvoorbeeld te realiseren loonkos- } \\
\text { ten) }\end{array}$ & $\begin{array}{l}\text { Toename } \\
\text { Afname }\end{array}$ & $\begin{array}{l}\text { Toename } \\
\text { Afname }\end{array}$ & $\begin{array}{l}\text { Trebit }+ \\
\text { Trebit - }\end{array}$ \\
\hline $\begin{array}{l}\text { 3c.verklarende positieve winst- } \\
\text { mutatierekening } \\
\text { (bijvoorbeeld omzetstijging als ge- } \\
\text { volg van nieuw produkt A) }\end{array}$ & $\begin{array}{l}\text { Toename } \\
\text { Afname }\end{array}$ & $\begin{array}{l}\text { Toename } \\
\text { Afname }\end{array}$ & $\begin{array}{l}\text { Trebit + } \\
\text { Trebit - }\end{array}$ \\
\hline $\begin{array}{l}\text { 3d.verklarende negatieve winst- } \\
\text { mutatierekening } \\
\text { (bijvoorbeeld toename loonkosten } \\
\text { als gevolg van nieuwe } \mathrm{CAO} \text { ) }\end{array}$ & $\begin{array}{l}\text { Toename } \\
\text { Afname }\end{array}$ & $\begin{array}{l}\text { Afname } \\
\text { Toename }\end{array}$ & $\begin{array}{l}\text { Trebit - } \\
\text { Trebit + }\end{array}$ \\
\hline
\end{tabular}

$\mathrm{Na}$ verwerking van de financiële feiten dient het journaal, zoals steeds, in evenwicht te zijn. Dat wil zeggen:

totaal debet $=$ totaal credit $=$ totaal trebit.

Zoals bij de uitwerking van de CLM-case zal blijken, dragen de hiervoor gegeven boekingsregels er toe bij dat het bedoelde evenwicht steeds opgaat. 
Met betrekking tot de te administreren financiële feiten kan nu de volgende indeling worden gemaakt.

1. Financiële feiten waardoor uitsluitend de samenstelling van het eigen vermogen verandert (Ijiri spreekt van 'intra-wealth transactions', 1982:13), zoals een geldontvangst van een debiteur en de inkoop van handelsgoederen, worden in beginsel alleen in de debet-kolom van het journaal verantwoord.

2. Financiële feiten waardoor uitsluitend de saldi van vermogensrekeningen muteren en derhalve uitsluitend de omvang van het eigen vermogen betreffen ('intra-capital transactions'), zoals bij een herkapitalisatie, worden in beginsel alleen in de creditkolom van het journaal verantwoord.

3. Financiële feiten waardoor niet alleen de samenstelling maar ook de omvang van het eigen vermogen verandert ('capital-wealth transactions'), zoals een verkooptransactie met winst of het vormen van een voorziening, komen zowel in de debet-, credit- als in de trebit-kolom voor. Bij dergelijke transacties moet niet enkel worden aangeven welke bezittingen en/of schulden zijn veranderd en welke winst- en verliesrekeningen zijn gemuteerd, maar ook de winstkrachten die voor deze realisatie verantwoordelijk zijn.

4. Financiële feiten waardoor uitsluitend winstsnelheids-mutaties ontstaan ${ }^{13}$ (zijnde veranderingen in de winstsnelheid van het eigen vermogen en - dientengevolge veranderingen in het periodieke resultaat), zoals een bericht van de bank dat de rente op deposito's is verlaagd of een besluit van het verkoopmanagement de verkoopprijs op de produkten met $5 \%$ te verlagen, worden alleen in de trebit-kolom genoteerd.

In geval van winstuitkering (dividend) neemt weliswaar de omvang van het eigen vermogen af, maar dit betekent meestal niet dat ook de winstsnelheid van het vermogen afneemt. Dit betekent dat de winstuitkering in principe alleen op een controlerende winstmutatierekening in de trebitkolom wordt verwerkt ${ }^{14}$.

Bij de administratie van het ontstaan/tenietgaan van winstkrachten kan een nadere classificatie worden aangebracht (zie ook paragraaf 7.5.6). Te denken valt aan interne en externe winstkrachten en incidentele en structurele winstkrachten. Ten aanzien van structurele winstkrachten ('recurring forces') bestaat de verwachting dat deze ook in de toekomst nog winst(snelheids)effecten zullen genereren. Inzicht in het type winstkrachten

\footnotetext{
${ }^{13}$ Men zou deze transacties als 'intra-momentum'-transacties kunnen aanduiden.

${ }^{14}$ Tenzij een verklaring voor een verandering in de winst ex dividend is gewenst.
} 
dat op het bedrijfsresultaat heeft ingewerkt, is onder andere van belang voor de beoordeling van de prestaties van het management en de beloning op basis hiervan alsmede voor het doen van uitspraken over toekomstig vermogen en winstniveau.

In het journaal zoals dat hierna wordt gepresenteerd, zijn de gegevens over 1992 verwerkt zoals die in paragraaf 8.2 ten aanzien van CLM zijn gegeven. Hierbij geldt dat de winstsnelheid van CLM per het einde van 1991 gelijk is aan Ũ 122.000 .000 per jaar, zijnde de over 1991 gerealiseerde winst. Dit betekent dat de winst over 1992 bij afwezigheid van nieuwe winstkrachten, eveneens Ũ 122.000 .000 zal bedragen.

CLM is in 1991 opgericht. Er wordt verondersteld dat het triple-entry accountingsysteem pas in 1992 wordt ingevoerd. Hierdoor is het journaal over 1991 vrijwel gelijk aan het journaal zoals dat is besproken bij toepassing van dubbel boekhouden. Alleen de vormgeving is anders, met name ten aanzien van het gebruik van de debet- en creditkolom en het gebruik van negatieve getallen.

Om reden van eenvoud is bij de opzet van het nieuwe, drie-dimensionale systeem verder verondersteld dat er zich in 1991 geen winstkrachten hebben gemanifesteerd. Bij genoemde veronderstelling kan de resultatenrekening over 1991 worden gebruikt als momentum statement per 31 december 1991.

Een verklaring voor de uitgevoerde boekingen is na het onderstaande journaal opgenomen. 
Journaal 1991 (bedragen x Ũ 1.000.000)

1. Liquide middelen debet credit Goodwill Vorderingen Aandelenvermogen

2. Liquide middelen 100

Obligatielening

3. Computers

Liquide middelen

$-360$

4. Liquide middelen 360 Huuropbrengsten

5. Computers

Afschrijvingskosten computer

6. Liquide middelen

Onderhoudskosten

7. Liquide middelen

Netto winst

8. Goodwill

Afschrijvingskosten goodwill

9. Liquide middelen

Rentelasten

10. Netto winst

Winstreserves

11. Liquide middelen Vorderingen $(180-100)$ 
Verklaring voor uitgevoerde boekingen (bedragen x Ũ 1.000.000)

1. De post 'Liquide middelen' (een positief vermogensbestanddeel) neemt toe waardoor het eigen vermogen toeneemt (debet +70 ). De post 'Goodwill' (een positief vermogensbestanddeel) neemt toe waardoor het eigen vermogen toeneemt (debet +50 ). De post 'Vorderingen' (een positief vermogensbestanddeel) neemt toe waardoor het eigen vermogen toeneemt (debet +180 ). De post 'Aandelenvermogen' (een positieve vermogensrekening) neemt toe waardoor de omvang van het eigen vermogen toeneemt (credit +300$)$.

2. De post 'Liquide middelen' (een positief vermogensbestanddeel) neemt toe waardoor het eigen vermogen toeneemt (debet +100 ). De post 'Obligatielening' (een negatief vermogensbestanddeel) neemt toe waardoor het eigen vermogen afneemt (debet $-/-100)$.

3. De post 'Computers' (een positief vermogensbestanddeel) neemt toe waardoor het eigen vermogen toeneemt (debet +360 ). De post 'Liquide middelen' (een positief vermogensbestanddeel) neemt af waardoor het eigen vermogen afneemt (debet $-\gamma$ 360 ).

4. De post 'Liquide middelen' (een positief vermogensbestanddeel) neemt toe waardoor het eigen vermogen toeneemt (debet +360 ). De post 'Huuropbrengsten' (een positieve vermogensrekening) neemt toe waardoor het eigen vermogen toeneemt $($ credit +360$)$.

5. De post 'Computers' (een positief vermogensbestanddeel) neemt af waardoor het eigen vermogen afneemt (debet -/120). De post 'Afschrijvingskosten computers' (een negatieve vermogensrekening) neemt toe waardoor de omvang van het eigen vermogen afneemt (credit $-/-120$ ).

6. De post 'Liquide middelen' (een positief vermogensbestanddeel) neemt af waardoor het eigen vermogen afneemt (debet -/-98). De post 'Onderhoudskosten' (een negatieve vermogensrekening) neemt toe waardoor de omvang van het eigen vermogen afneemt (credit $-/-98$ ).

7. De post 'Liquide middelen' (een positief vermogensbestanddeel) neemt af waardoor het eigen vermogen afneemt (debet -/-36). De post 'Netto winst' (een positieve vermogensrekening) neemt af waardoor het eigen vermogen afneemt (credit -/-36). 
8. De post 'Goodwill' (een positief vermogensbestanddeel) neemt af waardoor het eigen vermogen afneemt (debet -/-10). De post 'Afschrijvingskosten goodwill' (een negatieve vermogensrekening) neemt toe waardoor de omvang van het eigen vermogen afneemt (credit $-/-10$ ).

9. De post 'Liquide middelen' (een positief vermogensbestanddeel) neemt af waardoor het eigen vermogen afneemt (debet -/-10). De post 'Rentelasten' (een negatieve vermogensrekening) neemt toe waardoor de omvang van het eigen vermogen afneemt (credit $-/-10)$.

10. De post 'Netto winst' (een positieve vermogensrekening) neemt af waardoor de omvang van het eigen vermogen afneemt (credit -/-86). De post 'Winstreserves' (een positieve vermogensrekening) neemt toe waardoor de omvang van het eigen vermogen toeneemt $($ credit +86$)$.

11. De post 'Liquide middelen' (een positief vermogensbestanddeel) neemt toe waardoor het eigen vermogen toeneemt (debet +80 ). De post 'Vorderingen' (een positief vermogensbestanddeel) neemt af waardoor het eigen vermogen afneemt (debet $-/-80$ ).

Het journaal voor CLM over 1992 bij toepassing van differential triple-entry accounting is substantieel anders dan het journaal over 1992 bij toepassing van dubbel boekhouden. Dit moge uit het volgende overzicht blijken. Een verklaring voor de uitgevoerde boekingen is na dit overzicht opgenomen.

CLM Journaal 1992 (bedragen $\times$ Ũ 1.000.000)

debet credit trebit

1. Toename onderhoudskosten als

gevolg van intensivering

onderhoud

Te realiseren onderhoudskosten

2. Computers

400

Liquide middelen

3. Toename huuropbrengsten als gevolg van uitbreiding netwerk Ongerealiseerde toename huuropbrengsten als gevolg van uitbreiding netwerk 
8 Operationalisering concept triple-entry en momentum accounting

Toename onderhoudskosten als gevolg van uitbreiding netwerk

Te realiseren onderhoudskosten

4. Afname huuropbrengsten

als gevolg van uitbreiding

netwerk

Ongerealiseerde afname

huuropbrengsten als gevolg van

uitbreiding netwerk

Te realiseren huuropbrengsten

5. Liquide middelen

486.5

Huuropbrengsten

486.5

Te realiseren huuropbrengsten

6. Liquide middelen

Onderhandse lening

Toename rentelasten als gevolg van nieuwe lening

Ongerealiseerde toename

rentelasten als gevolg van

nieuwe lening

6

Te realiseren rentelasten

7. Computers

Afschrijvingskosten computers

Te realiseren afschrijvingskosten computers

Toename afschrijvingskosten als gevolg van uitbreiding netwerk

Ongerealiseerde toename atschrijvingskosten toename als gevolg van uitbreiding netwerk

8. Liquide middelen

Rentelasten

Te realiseren rentelasten

9. Afname huuropbrengsten als gevolg van toegenomen concurrentie

Ongerealiseerde afname huuropbrengsten als gevolg van toegenomen concurrentie

$\mathrm{Te}$ realiseren huuropbrengsten

Afname onderhoudskosten als gevolg van daling huuropbrengsten door toegenomen concurrentie 
Ongerealiseerde afname

onderhoudskosten als gevolg van

daling huuropbrengsten door

toegenomen concurrentie

Te realiseren onderhoudskosten

10. Liquide middelen

$-169.5$

Onderhoudskosten

$-169.5$

Te realiseren onderhoudskosten

11. Liquide middelen

$-60$

Netto winst

$-60$

Te realiseren dividenduitkering

$-36$

Toename dividenduitkeringen

12. Goodwill

$-10$

Afschrijvingskosten goodwill

Te realiseren afschrijvingskosten goodwill

13. Netto winst

Winstreserves

14. Liquide middelen

Incidentele lasten en baten

$-26$

Reorganisatie

15. Toename onderhoudskosten als gevolg van nieuwe $\mathrm{CAO}$

Ongerealiseerde toename onderhoudskosten als gevolg van nieuwe $\mathrm{CAO}$

16. Liquide middelen

Vorderingen

17. Afname huuropbrengsten als gevolg van toegenomen concurrentie

Ongerealiseerde afname huuropbrengsten als gevolg van

toegenomen concurrentie

Te realiseren huuropbrengsten 


\section{Verklaring voor uitgevoerde boekingen (bedragen $\times \tilde{U} 1.000 .000)$}

1. Ten gevolge van dit besluit neemt een negatieve winstkracht toe waarvoor in de trebitkolom op de rekening 'Toename onderhoudskosten als gevolg van intensivering onderhoud' (een verklarende negatieve winst-mutatierekening) een negatief bedrag wordt ingegeven omdat het eigen vermogen afneemt (trebit -1-32). Het saldo op de rekening 'Te realiseren onderhoudskosten' (een controlerende negatieve winst-mutatierekening) neemt toe. Hierdoor neemt het eigen vermogen toe ${ }^{15}$ waarvoor in de trebitkolom +32 wordt ingegeven (trebit +32 ).

2. De rekening 'Computers' (positief vermogensbestanddeel) wordt in de debetkolom met een positief getal ingevoerd (debet +400 ) omdat met de toename van de computers het eigen vermogen toeneemt. De rekening 'Liquide middelen' (een positief vermogensbestanddeel) wordt met een negatief getal in de debetkolom ingevoerd (debet $-/-400$ ) omdat met de afname van de liquide middelen ook het eigen vermogen afneemt.

3. De rekening 'Toename huuropbrengsten als gevolg van uitbreiding netwerk' (een verklarende positieve winst-mutatierekening) zou in de trebitkolom met een positief getal kunnen worden ingevoerd omdat het (potentiële) eigen vermogen toeneemt (trebit +168 ). Aangezien het op jaarbasis echter gaat om een toename van de huuropbrengsten met $12 \times 28=336$, wordt dit jaareffect op de rekening 'Toename huuropbrengsten als gevolg van uitbreiding netwerk' geadministreerd (trebit +336 ). Als 'correctie' hierop voor 1992 wordt de rekening 'Ongerealiseerde toename huuropbrengsten als gevolg van uitbreiding netwerk' (een contra-rekening) voor het verschil negatief in de trebitkolom ingevoerd (trebit -1-168). Door de effecten op jaarbasis te administreren, komen gegevens over de ontwikkelingen in de winstsnelheid van het eigen vermogen ('income momentum') beschikbaar. Bij de opmaak van de winst-mutatiestaat wordt hierop teruggekomen. Het saldo op de rekening 'Te realiseren huuropbrengsten' (een controlerende positieve winstmutatierekening) dient te worden opgehoogd. Hiervoor wordt in de trebitkolom -/168 ingegeven omdat het eigen vermogen afneemt, dat wil zeggen: de hiervoor besproken toename van het eigen vermogen ten gevolge van de uitbreiding van het computernetwerk, is nog niét gerealiseerd. Het betreft hier als het ware een 'sollboeking', dat wil zeggen: de boeking van een opdracht. De mate waarin deze

\footnotetext{
${ }^{15}$ Alhoewel er sprake is van een afname van de winstcapaciteit van het eigen vermogen, is deze daling nog niet verwezenlijkt (gerealiseerd) in het winstcijfer. Vandaar dat deze afname die op de rekening 'Toename onderhoudskosten als gevolg van intensivering onderhoud' in de trebitkolom tot uitdrukking is gebracht, wordt 'gecorrigeerd' met een toename van het eigen vermogen en derhalve een tegengestelde boeking in de zelfde kolom op de rekening 'Te realiseren onderhoudskosten'.
} 
opdracht wordt gerealiseerd, ('de ist-boeking') wordt bij onderdeel 5 geadministreerd.

De rekening 'Toename onderhoudskosten als gevolg van uitbreiding netwerk' (een verklarende negatieve winst-mutatierekening) kan in de trebitkolom met een negatief getal worden ingevoerd (trebit -/-40) omdat het (potentiële) eigen vermogen afneemt. Aangezien dit bedrag tevens de toename van de kosten op jaarbasis betreft, hoeft geen correctie in de zin van een contra-rekening voor het in 1992 niét te realiseren deel te worden ingevoerd. De rekening 'Te realiseren onderhoudskosten' (een controlerende winst-mutatierekening) dient te worden opgehoogd waarvoor in de trebitkolom +40 wordt ingegeven omdat het eigen vermogen toeneemt, dat wil zeggen: de toename van de onderhoudskosten ten gevolge van de uitbreiding van het computernetwerk is nog niét gerealiseerd.

4. Voor de effecten van de termijnverlaging zou de verklarende negatieve winstmutatierekening 'Afname huuropbrengsten als gevolg van uitbreiding netwerk' in de trebitkolom met een negatief getal kunnen worden ingevoerd omdat het (potentiële) eigen vermogen afneemt $\{6 \times(24-30)=-/-36\}$. Maar aangezien de afname van de huuropbrengsten ten gevolge van het op de markt brengen van de nieuwe computers op jaarbasis $12 \times(24-30)=-/-72$ bedraagt, wordt dit bedrag op genoemde rekening in de trebitkolom ingebracht (trebit -/-72). Voor 1992 corrigeren we deze afname door in de trebitkolom een positief bedrag van 36 op te nemen bij de rekening 'Ongerealiseerde afname huuropbrengsten als gevolg van uitbreiding netwerk' (een contra-rekening voor een verklarende positieve winst-mutatierekening). De rekening 'Te realiseren huuropbrengsten' (een controlerende positieve winst-mutatierekening) wordt voor 1992 verlaagd met 36 waarvoor we in de trebitkolom +36 ingeven omdat het eigen vermogen toeneemt, dat wil zeggen: de gesignaleerde daling van het eigen vermogen is nog niét gerealiseerd.

5. De post 'Liquide middelen' (een positief vermogensbestanddeel) wordt in de debetkolom met een positief getal ingevoerd omdat met de toename van deze middelen het eigen vermogen toeneemt (debet +486.5 ). De rekening 'Huuropbrengsten' (een positieve vermogensrekening) wordt in de creditkolom met een positief getal ingevoerd (credit +486.5 ) omdat hiermee de omvang van het eigen vermogen is toegenomen. De rekening 'Te realiseren huuropbrengsten' (een controlerende positieve winst-mutatierekening) wordt in de trebitkolom met een positief bedrag ingevoerd (trebit +486.5 ) omdat vanwege de gerealiseerde huuropbrengsten het saldo op deze rekening dient te worden verminderd en het eigen vermogen met het zelfde bedrag is toegenomen. 
6. 'Liquide middelen', een positief vermogensbestanddeel, wordt in de debetkolom met een positief getal ingevoerd (debet +100 ) omdat met de toename van deze middelen ook het eigen vermogen toeneemt. De rekening 'Onderhandse lening' (een negatief vermogensbestanddeel) wordt met een negatief getal in de debetkolom ingevoerd (debet $-/-100$ ) omdat met het opnemen van deze lening het eigen vermogen afneemt.

Naar aanleiding van de extra rentelasten ten gevolge van de nieuwe lening kunnen we in de trebitkolom op de rekening 'Toename rentelasten als gevolg van nieuwe lening' (een verklarende negatieve winst-mutatierekening) een bedrag van $-/-12$ inbrengen, omdat met deze extra kosten het eigen vermogen afneemt. Omdat de betreffende rentekosten in 1992 slechts voor de helft zullen worden gerealiseerd, corrigeren we de rekening 'Toename rentelasten als gevolg van nieuwe lening' in de trebitkolom met de invoer van +6 op de rekening 'Ongerealiseerde toename rentelasten als gevolg van nieuwe lening' (een contra-rekening). Het deel van de toename van de rentekosten dat in 1992 zal worden gerealiseerd, wordt toegevoegd aan de controlerende negatieve winst-mutatierekening 'Te realiseren rentelasten'. Hiervoor wordt in de trebitkolom op deze rekening +6 ingevoerd om een toename van het eigen vermogen tot uitdrukking te brengen omdat de hiervoor verwerkte afname van dit vermogen, nog niét is gerealiseerd.

7. De afname van de post 'Computers' (een positief vermogensbestanddeel) betekent dat in de debetkolom een negatief getal $(-/-180)$ wordt ingevoerd omdat hiermee het eigen vermogen afneemt. De rekening 'Afschrijvingskosten computers' (een negatieve vermogensrekening) wordt in de creditkolom met een negatief getal ( $/-$ 180 ) ingevoerd omdat hiermee de omvang van het eigen vermogen afneemt. De rekening 'Te realiseren afschrijvingskosten' (een controlerende negatieve winstmutatierekening) wordt in de trebitkolom met een negatief bedrag $(-/-180)$ ingevoerd omdat door de kosten het eigen vermogen afneemt. Het journaal is nu in evenwicht. Echter, de voor 1992 geboekte te realiseren afschrijvingskosten bedroegen slechts $12 \times 10=120^{16}$. Om deze reden wordt de rekening 'Te realiseren afschrijvingskosten' in de trebitkolom dan ook met -/-120 gemuteerd. We kunnen dit corrigeren door op de rekening 'Toename afschrijvingskosten als gevolg van uitbreiding netwerk' (een verklarende negatieve winst-mutatierekening) een bedrag van $-/-60$ in de trebitkolom in te voeren. Hierna is het journaal wederom in evenwicht. Maar aangezien de toename van de afschrijvingskosten op jaarbasis niét 60 maar $12 \times 10=120$ bedraagt, is het nodig de rekening 'Toename afschrijvingskosten als gevolg van uitbreiding netwerk' in de trebitkolom op te nemen voor $-/-120$ in plaats van voor $-/-60$. Deze 'overtrebitering' wordt gecorrigeerd

\footnotetext{
${ }^{16}$ Tenzij bij het verhuren van de nieuwe computers (onderdeel 3) het saldo van deze rekening is opgehoogd van 120
} naar 240. 
door in de trebitkolom op de rekening 'Ongerealiseerde toename afschrijvingskosten als gevolg van uitbreiding netwerk' (een contra-rekening) een bedrag van +60 in te geven. Dit is het bedrag aan extra afschrijvingskosten dat in 1992 niét zal worden gerealiseerd.

8. De rekening 'Liquide middelen' (een positief vermogensbestanddeel) wordt in de debetkolom met een negatief getal $(-/-16)$ ingevoerd omdat met de afname van deze middelen ook het eigen vermogen afneemt. De rekening 'Rentelasten' (een negatieve vermogensrekening) wordt met een negatief getal in de creditkolom ingevoerd (-/16) omdat met deze kosten de omvang van het eigen vermogen afneemt. Het saldo op de rekening 'Te realiseren rentelasten' (een controlerende negatieve winst-mutatierekening) neemt af waarvoor trebit $-/-16$ wordt ingegeven omdat het eigen vermogen is afgenomen.

9. Op jaarbasis neemt de verhuuromzet met $4 \times 2.5=10 \mathrm{af}$. Voor dit bedrag wordt de verklarende negatieve winst-mutatierekening 'Afname huuropbrengsten als gevolg van toegenomen concurrentie' in de trebitkolom ingevoerd, omdat het eigen vermogen afneemt (trebit $-/-10$ ). Omdat 7.5 van dit bedrag in 1992 niét zal worden gerealiseerd, wordt de contra-rekening 'Ongerealiseerde afname huuropbrengsten als gevolg van toegenomen concurrentie' trebit ingevoerd voor +7.5 . Het saldo op de controlerende positieve winst-mutatierekening 'Te realiseren huuropbrengsten' neemt af, derhalve neemt het eigen vermogen toe (de hiervoor tot uitdrukking gebrachte afname is nog niét gerealiseerd). In verband hiermee wordt in de trebitkolom +2.5 ingevoerd.

Op jaarbasis nemen de onderhoudskosten af als gevolg van de daling van de verhuuromzet met $4 \times 0.5=2$. Voor dit bedrag wordt de verklarende negatieve winst-mutatierekening 'Afname onderhoudskosten als gevolg van daling huuropbrengsten door toegenomen concurrentie' in de trebitkolom ingevoerd (trebit +2 ) omdat het eigen vermogen met dit bedrag toeneemt. Aangezien van deze verwachte teruggang in de kosten in 1992 slechts $0.5 \mathrm{zal}$ worden gerealiseerd, wordt op een contra-rekening 'Ongerealiseerde afname onderhoudskosten als gevolg van daling huuropbrengsten door toegenomen concurrentie' in de trebitkolom $-/-1.5$ ingegeven. Tenslotte wordt in de trebitkolom bij de controlerende negatieve winst-mutatierekening 'Te realiseren onderhoudskosten' $-/-0.5$ ingegeven. Het saldo op deze rekening neemt af en dientengevolge neemt ook het eigen vermogen af.

10. De rekening 'Liquide middelen' (een positief vermogensbestanddeel) wordt in de debetkolom ingevoerd veor -/-169.5 omdat door de afname van deze middelen het eigen vermogen afneemt. De rekening 'Onderhoudskosten' (een negatieve vermo- 
gensrekening) wordt in de creditkolom voor $-/-169.5$ ingevoerd omdat met deze kosten de omvang van het eigen vermogen afneemt. Het saldo op de controlerende negatieve winst-mutatierekening 'Te realiseren onderhoudskosten' vermindert en de hiermee gepaard gaande daling van het eigen vermogen komt tot uitdrukking door in de trebitkolom $-/-169.5$ in te geven.

11. De rekening 'Liquide middelen' (een positief vermogensbestanddeel) wordt in de debetkolom ingevoerd voor $-/-60$ omdat door de afname van deze middelen het eigen vermogen afneemt. De rekening 'Netto winst' (een positieve vermogensrekening) wordt in de creditkolom met een negatief bedrag gemuteerd (credit -/-60) omdat door de winstuitkering de omvang van het eigen vermogen afneemt. Het saldo op de controlerende negatieve winst-mutatierekening 'Te realiseren dividenduitkering' vermindert en dientengevolge neemt het eigen vermogen af. De aantekening in de trebitkolom is dan ook $-/-36$. De verklarende negatieve winstmutatierekening 'Toename dividenduitkeringen' wordt in de trebitkolom voor -/-24 ingegeven omdat ten gevolge van de toegezegde hogere dividenduitkeringen het eigen vermogen is afgenomen ${ }^{17}$.

12. De post 'Goodwill' (een positief vermogensbestanddeel) wordt in de debetkolom voor $-/-10$ gemuteerd omdat door de afname van dit actief ook het eigen vermogen vermindert. De post 'Afschrijvingskosten goodwill' (een negatieve vermogensrekening) wordt in de creditkolom voor $-/-10$ ingevoerd omdat ten gevolge van deze kosten de omvang van het eigen vermogen afneemt. Het saldo op de controlerende negatieve winst-mutatierekening ' $\mathrm{Te}$ realiseren afschrijvingskosten goodwill' neemt af en derhalve ook het eigen vermogen. In de trebitkolom wordt in dit verband $-/$ 10 ingegeven.

13. De rekening 'Netto winst' (een positieve vermogensrekening) wordt in de creditkolom voor $-/-25$ ingevoerd omdat door het afnemen van deze post de omvang van het eigen vermogen afneemt. De rekening 'Winstreserves' (ook een positieve vermogensrekening) wordt in de creditkolom voor +25 ingevoerd omdat met de toename van de reserves ook de omvang van het eigen vermogen toeneemt.

\footnotetext{
${ }^{17}$ Wanneer de kosten over het vorige verslagjaar als positief worden geopend en de opbrengsten als negatief, dan wordt in verband met het noodzakelijke evenwicht in het grootboek de winst over het vorige jaar als zijnde positief geopend. De dividenduitkering maakt deel uit van deze winst en wordt daarom als zodanig ook positief geopend. Noch de rekening 'Te realiseren dividenduitkering', noch de rekening 'Toename dividenduitkeringen' is een 'echte' winstmutatie-rekening omdat het dividend uit de winst wordt uitgekeerd en derhalve geen winstmutatie kan verklaren. De betreffende rekening is toch als zodanig opgevoerd opdat inzicht wordt verkregen in de oorzaken van het verschil in de winst ex dividend.
} 
14. De rekening 'Liquide middelen' (een positief vermogensbestanddeel) wordt in de debetkolom voor $-/-26$ gemuteerd omdat met de afname van deze middelen ook het eigen vermogen afneemt. De rekening 'Incidentele lasten en baten' (in dit geval een negatieve vermogensrekening) wordt in de debetkolom voor $-/-26$ ingevoerd omdat ten gevolge van de betreffende lasten de omvang van het eigen vermogen afneemt. In de trebitkolom wordt de verklarende (in dit geval negatieve) winstmutatierekening 'Reorganisatie' voor $-/-26$ ingegeven omdat met de betreffende kosten de omvang van het eigen vermogen is afgenomen.

15. De verklarende negatieve winst-mutatierekening 'Toename onderhoudskosten als gevolg van nieuwe CAO' wordt in de trebitkolom met -/-12 gemuteerd omdat ten gevolge van de nieuwe loonafspraken de toekomstige kosten stijgen en daarmee het eigen vermogen afneemt. Omdat echter deze kostentoename voor het eerst in 1993 zal worden gerealiseerd, wordt tegelijkertijd de contra-rekening 'Ongerealiseerde toename onderhoudskosten als gevolg van nieuwe CAO' in de trebitkolom met +12 ingevoerd.

16. Eind 1991 bedroegen de vorderingen 100. Wanneer deze eind 1992 nog 60 bedragen, betekent dit dat meer aan liquide middelen (in casu voor 40 ) is binnengekomen dan de verhuuromzet bedroeg (zie onderdeel 5). In dit verband wordt de rekening 'Liquide middelen' (een positief vermogensbestanddeel) in de debetkolom voor +40 ingevoerd omdat met de toename van deze middelen ook het eigen vermogen is toegenomen. In de debetkolom wordt de rekening 'Vorderingen' (een positief vermogensbestanddeel) voor $-/-40$ ingevoerd omdat met de afname van de vorderingen tevens het eigen vermogen is afgenomen.

17. De afname van de huuropbrengsten op jaarbasis is $4 \times 3=12$. In verband hiermee wordt in de trebitkolom op de verklarende negatieve winst-mutatierekening 'Afname huuropbrengsten als gevolg van toegenomen concurrentie' -/-12 ingevoerd omdat door het achterblijven van de omzet het eigen vermogen zal afnemen. Aangezien van deze afname van de verhuuropbrengsten in 1992 slechts voor een bedrag van $-/-3$ is gerealiseerd, wordt in de trebitkolom tevens een contra-rekening 'Ongerealiseerde afname verhuuropbrengsten als gevolg van toegenomen concurrentie' voor +9 ingebracht. Het saldo op de controlerende winst-mutatierekening 'Te realiseren huuropbrengsten' is voor 1992 met 3 verminderd en de toename van het eigen vermogen die hiervan het gevolg is (teneinde de eerder aangegeven afname van het eigen vermogen deels teniet te doen), wordt in de trebitkolom met +3 tot uitdrukking gebracht. 
Op basis van het hiervoor samengestelde joumaal kan thans de winst-mutatiestaat worden opgemaakt. Hiertoe gaan we eerst na of bepaalde controlerende winst-mutatierekeningen nog een saldo vertonen. Indien dit het geval is, dient het betreffende bedrag alsnog met een verklaring (oorzaak) naar de winst-mutatiestaat te worden overgeboekt. In het geval de verschillen niét materieel zijn, kan op de winst-mutatiestaat worden volstaan met een post 'Residu'. Hierna volgt een overzicht van de gebruikte controlerende winst-mutatierekeningen en de hierop geboekte positieve en negatieve bedragen. (Tussen haakjes staan de journaal-onderdelen vermeld waaraan de mutaties zijn ontleend).

\section{Te realiseren huuropbrengsten}

opening (resultatenrekening 1991, begin-momentum)

(3)

To realiseren onderhoudskosten

opening (resultatenrekening 1991, begin-momentum)

Te realiseren afschrijvingskosten computers

Te realiseren rentelasten opening (resultatenrekening 1991, begin-momentum)



Te realiseren afschrijvingskosten goodwill opening (resultatenrekening 1991, begin-momentum) (12)

Te realiseren dividenduitkeringen opening (resultatenrekening 1991, begin-momentum) (11) 
Aldus lopen alle controlerende winst-mutatierekeningen glad.

Thans kunnen alle saldi van de verklarende winst-mutatierekeningen naar de winstmutatiestaat worden overgeboekt. Hierbij dient rekening te worden gehouden met de bedragen op de betreffende contra-rekeningen waarop de ongerealiseerde effecten van de opgetreden winstkrachten zijn geadministreerd. In het hierna volgende overzicht (tabel 8.3) zijn deze ongerealiseerde effecten samengevat (zie de journaalposten voor de betreffende bedragen).

Tabel 8.3 Overzicht van nog niét gerealiseerde effecten van opgetreden winstkrachten.

\begin{tabular}{|ll|c|}
\hline \multicolumn{2}{|c|}{ naam van de post } & bedrag \\
\hline 1. & $\begin{array}{l}\text { Ongerealiseerde toename huuropbrengsten als gevolg van uitbrei- } \\
\text { ding netwerk }\end{array}$ & -168 \\
\hline 2. & $\begin{array}{l}\text { Ongerealiseerde afname huuropbrengsten als gevolg van uit- } \\
\text { breiding netwerk }\end{array}$ & 36 \\
\hline 3. & Ongerealiseerde toename rentelasten als gevolg van nieuwe lening & 6 \\
\hline $4 . \quad \begin{array}{l}\text { Ongerealiseerde toename afschrijvingskosten als gevolg van uit- } \\
\text { breiding netwerk }\end{array}$ & 60 \\
\hline 5. & $\begin{array}{l}\text { Ongerealiseerde afname huuropbrengsten als gevolg van toegeno- } \\
\text { men concurrentie }\end{array}$ & 7,5 \\
\hline 6. & $\begin{array}{l}\text { Ongerealiseerde afname onderhoudskosten als gevolg van daling } \\
\text { huuropbrengsten door toegenomen concurrentie }\end{array}$ & $-1,5$ \\
\hline 7. & $\begin{array}{l}\text { Ongerealiseerde toename onderhoudskosten als gevolg van nieuwe } \\
\text { CAO }\end{array}$ & 12 \\
\hline 8. & $\begin{array}{l}\text { Ongerealiseerde afname huuropbrengsten als gevolg van toege- } \\
\text { nomen concurrentie }\end{array}$ & 9 \\
\hline Totaal & -39 \\
\hline
\end{tabular}

Het saldo van deze ongerealiseerde krachten wordt eveneens naar de winst-mutatiestaat overgeboekt. Hierna is de winst-mutatiestaat compleet en is een volledige verklaring beschikbaar voor het verloop in de tijd van het winstcijfer van 122 (1991) naar 85 (1992). 
8 Operationalisering concept triple-entry en momentum accounting

De winst-mutatiestaat over 1992 voor CLM zou er als volgt kunnen uitzien.

\section{Winst-mutatiestaat over 1992 CLM (x U 1.000.000)}

\section{Nieuw netwerk}

Toename huuropbrengsten

Afname huuropbrengsten bestaand netwerk

Netto-opbrengsten nieuw netwerk

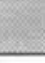

Netto-opbrengsten nieuw netwerk

Toename onderhoudskosten

Toename afschrijvingskosten

Toename rentelasten

Totaal toegerekende kosten

Mutatie winstbijdrage (op jaarbasis)

336

$-72$

264

40

120

12

$\underline{172}$

92

\section{Concurrentie}

Afname opbrengsten als gevolg van toegenomen concurrentie

Afname gerelateerde onderhoudskosten

Invloed concurrentie op resultaat jaarbasis

\section{Overig}

Toename onderhoudskosten door

intensivering onderhoud bestaand netwerk

Toename loonkosten als gevolg van nieuwe CAO

Winstmutatie in $1992^{18}$

Winst 1991

Winstcapaciteit ('income momentum') per jaar per 31-12-92

Reorganisatieverlies 1992 (zie joumaalpost 14)

Niet-gerealiseerde winstkrachten (zie tabel 8.3)

Netto-winst 1992

$-32$

$-12$ $-44$

In dit bedrag zijn alle winstkrachten op jaarbasis berekend en als zodanig is dit bedrag de winstsnelheid van het eigen vermogen van CLM per jaar zoals gemeten per 31 december 1992.

De hiervoor opgestelde winst-mutatiestaat is feitelijk een 'mengsel' van 'action statement' (=winst-mutatiestaat) en 'impulse statement' (=winstsnelheids-mutatiestaat). De toename

${ }^{18} \mathrm{Dit}$ is de toename van de winstsnelheid ('income momentum') op jaarbasis. 
van de winstsnelheid van het eigen vermogen van de onderneming is aanzienlijk, in casu van Ũ 122.000.000 naar Ũ 150.000.000. Deze financiële prestatie komt in het dubbel boekhouden niét tot uitdrukking. Hier wordt feitelijk een winstval van Ũ 122.000 .000 naar Ũ 85.000.000 gepresenteerd. Als zodanig kan de winst-mutatiestaat er toe bijdragen dat een bedrijfsbeoordeling casu quo management-beoordeling verantwoorder plaatsvindt.

Bij een 'income momentum' per jaar van Ũ 150.000 .000 per 31 december 1992, bedraagt de voor 1993 te verwachten winst in eerste instantie ook Ũ 150.000.000. Dit bedrag kan vervolgens voor in 1993 voorziene omzet- en kostenontwikkelingen worden aangepast. Stel dat voor 1993 er van wordt uitgegaan dat, als gevolg van groot onderhoud, gemiddeld slechts $90 \%$ van de capaciteit in gebruik is. Voor dit onderhoud is nog geen voorziening getroffen. De controller van CLM heeft berekend dat als gevolg van dit groot onderhoud de opbrengst uit verhuur eenmalig zal dalen met Ũ 62.400 .000 en dat incidenteel extra onderhoudskosten zullen worden gemaakt voor het bedrag van Ũ 27.750.000. Rekening houdend met de effecten van deze in 1993 verwachte financiële feiten, zal de winstvoorspelling voor 1993 er als volgt zijn (zie tabel 8.4).

Tabel 8.4 Winstvoorspelling voor CLM over 1993 bij toepassing van differential triple-entry accounting.

\begin{tabular}{|l|c|}
\hline Income momentum per jaar per 31-12-1992 & Ũ 150.000 .000 \\
\hline Verwachte omzetdaling (incidenteel) & $-\tilde{U} 62.400 .000$ \\
\hline Verwachte kostenstijging (incidenteel) & $-\tilde{\text { U } 27.750 .000}$ \\
\hline Begrote winst 1993 & $\tilde{\mathbf{U}} \mathbf{5 9 . 8 5 0 . 0 0 0}$ \\
\hline
\end{tabular}

De winstvoorspelling voor 1993 is de zelfde als die welke is gedaan op basis van de in een dubbel boekhoudsysteem geadministreerde gegevens (zie tabel 8.1 in paragraaf 8.3). Maar de verwachting is dat het doen van een voorspelling voor de winst over 1993 bij de beschikbaarheid van gegevens over de 'income momentum', verantwoorder (systematischer) en sneller kan plaatsvinden.

\subsubsection{Financieel jaarverslag van CLM bij toepassing van differential triple- entry en momentum accounting}

Het financieel jaarverslag van CLM bij toepassing van differential triple-entry accounting zal voor een belangrijk deel gelijk zijn aan het jaarverslag zoals dat bij een dubbel boekhoudstelsel is opgesteld (zie paragraaf 8.3). Maar bij differential triple-entry accounting wordt naast de balans en resultatenrekening een belangrijk aanvullend overzicht gepresenteerd: de winst-mutatiestaat. Net als de balans en resultatenrekening 
kan ook dit overzicht van een toelichting worden voorzien (met name ten aanzien van de ongerealiseerde winstkrachten). Omdat in het geval CLM het gehele voortraject van de totstandkoming van de jaarrekening aan de orde is gesteld en derhalve alle detailgegevens van dit bedrijf als bekend kunnen worden verondersteld, wordt daarop hier niet verder ingegaan.

\subsection{Het journaal en grootboek bij differential triple-entry en momentum accounting nader bezien}

Ten opzichte van het journaal in het dubbel boekhoudsysteem zoals dat bij CLM zou kunnen worden opgesteld, is het journaal in geval van een drie-dimensionale administratie op belangrijke onderdelen anders. Het gaat hierbij met name om de financiële feiten waarvan invloed uitgaat op de winstcapaciteit van het eigen vermogen van de onderneming. Dergelijke feiten hebben betrekking op zich manifesterende winstkrachten ten gevolge waarvan het toekomstige winstniveau zal afwijken van het huidige winstniveau.

Het type controlerende winst-mutatierekeningen, respectievelijk verklarende winstmutatierekeningen dat in het grootboek zal worden aangelegd en de wijze waarop deze rekeningen van inhoud worden voorzien, zijn onder meer afhankelijk van de aard van het bedrijf, de juridische vorm, de aard van de organisatie en de informatiebehoeften van het betreffende management. Uit praktische overwegingen kan men besluiten de administratie op deze rekeningen te beperken tot de kritieke succesfactoren van het bedrijf.

Verklarende winst-mutatierekeningen kunnen op diverse wijzen nader worden onderverdeeld, bijvoorbeeld naar herkomst (intern/extern) van de krachten welke de winstmutaties hebben veroorzaakt.

Tot 'interne verklarende winst-mutatierekeningen' kunnen bijvoorbeeld rekeningen behoren als 'Nieuwe produkten', 'Research en ontwikkeling', 'Personeel', 'Reclame' en 'Efficiencyverbetering'.

'Externe verklarende winst-mutatierekeningen' kunnen bijvoorbeeld zijn: 'Algemeen economische groei', 'Concurrenten', 'Overheidsmaatregelen', 'Verandering wisselkoers dollar' en 'Verandering in rentepercentage'.

Vaak zullen deze rekeningen nog nader worden gespecificeerd. Zo kan de verklarende winst-mutatierekening 'Concurrenten' worden onderverdeeld in 'Nieuwe concurrenten', 'Reclame door concurrenten', 'Service door concurrenten' en 'Prijsveranderingen door concurrenten'.

Voor het beschikbaar kunnen stellen van de gegevens voor het bijwerken van de controlerende en verklarende winst-mutatierekeningen zijn belangrijke veranderingen in de administratieve organisatie (en interne controle) noodzakelijk. Op welke wijze worden de 
primaire financiële feiten met betrekking tot veranderingen in de 'income momentum' gesignaleerd en aan de financiële administratie gerapporteerd? Hiervoor dienen nieuwe boekingsdocumenten en administratieve procedures te worden ontwikkeld.

In veel gevallen zullen de gegevens voor het bijwerken van de verklarende winstmutatierekeningen reeds op enige plek in de organisatie aanwezig zijn. Het systematisch verwerken ervan vergt echter, zoals reeds gesteld, aanpassingen in de administratieve organisatie. Ook zullen er systemen en procedures moeten worden ontwikkeld ten einde deze gegevens uniform te kunnen verwerken alsmede om veranderingen in de 'income momentum' aan een of meerdere perioden te kunnen toerekenen ('matching'-vraagstuk).

\section{Openen van het grootboek}

In het grootboek worden niet alleen de balansrekeningen geopend, maar óók de controlerende winst-mutatierekeningen. Balansrekeningen worden op de zelfde wijze geopend als bij toepassing van dubbel boekhouden: rekeningen van bezit debet en rekeningen van schuld credit. In plaats van credit wordt bij de drie-dimensionale administratie - net als in het journaal - het bedrag op de grootboekrekening negatief in de debet-kolom opgenomen.

Controlerende winst-mutatierekeningen worden geopend door de bedragen van de resultatenrekening van de voorafgaande periode in de trebit-kolom op te nemen. Controlerende kostenrekeningen worden hierbij positief geopend en controlerende opbrengsten als negatief. Via het openen van deze rekeningen wordt de (gerealiseerde) 'income momentum' per het einde van een voorgaande verslagperiode naar de daarop volgende periode getransporteerd.

Verklarende winst-mutatierekeningen worden niét geopend. Op deze rekeningen worden de krachten vermeld die in de lopende verslagperiode een verandering teweeg hebben gebracht in het niveau van de winst ten opzichte van de vorige verslagperiode. De contrarekeningen voor de verklarende winst-mutatierekeningen (voor het vastleggen van de in de lopende verslagperiode ongerealiseerde effecten van winstkrachten) worden evenmin geopend. Immers uitgangspunt is dat deze effecten in de komende verslagperiode wél worden gerealiseerd.

\section{Bijwerken van het grootboek}

Het bijwerken van het grootboek is net als bij dubbel boekhouden een kwestie van het hierin overnemen van het samengestelde journaal. De vorm van de rekeningen is evenwel anders. Omdat met positieve en negatieve getallen wordt gewerkt, kunnen de bedragen in één kolom worden ingeschreven. 


\section{Afsluiten van het grootboek}

Bij het afsluiten van het grootboek wordt het saldo van de grootboekrekeningen bepaald en overgebracht naar het betreffende eindoverzicht (balans, resultatenrekening respectievelijk winst-mutatiestaat). Hierbij dient een bepaalde volgorde in acht te worden genomen.

Eerst worden de controlerende winst-mutatierekeningen afgesloten. In principe is het saldo van ieder van dit type rekeningen nihil. Is dit niet het geval, dan dient op basis van een nadere analyse alsnog een verklarende winst-mutatierekening voor het betreffende saldo te worden bijgewerkt.

Vervolgens worden de verklarende winst-mutatierekeningen afgesloten. De saldi van deze rekeningen worden overgebracht naar de winst-mutatiestaat. Hierbij dient tevens het saldo van de contra-rekeningen voor de verklarende winst-mutatierekeningen te worden bepaald en op de winst-mutatiestaat te worden opgenomen.

Daarna worden de resultaatrekeningen afgesloten, waarbij de resultatenrekening wordt verkregen. Tenslotte worden de balansrekeningen afgesloten en wordt de eindbalans verkregen. Desgewenst worden toelichtingen gegeven bij elk van de op de overzichten opgenomen posten.

De balans, resultatenrekening en winst-mutatiestaat geven inzicht in de samenstelling en de grootte van het eigen vermogen per het einde van de verslagperiode, in de in de verslagperiode opgetreden verandering in de grootte van het eigen vermogen en in de krachten welke een verandering in de verandering van de omvang (= winstcapaciteit) van het eigen vermogen hebben teweeg gebracht. Aldus ontstaat een financieel verslag op basis van (differential) triple-entry accounting.

Bij de oprichting van de onderneming en de inbreng van het eigen vermogen kan in de trebit-kolom van de rentekosten ('opportunity'-kosten) een aantekening worden gemaakt. Stel dat voor CLM wordt uitgegaan van $15 \%$ op jaarbasis over de inbreng ad U 300.000 .000 . Voor het bedrag van Ũ 45.000 .000 wordt dan een verklarende positieve winst-mutatierekening positief getrebiteerd, bijvoorbeeld 'Toename eigen vermogen'.

Omdat bedoelde toename van het eigen vermogen nog niet is gerealiseerd, dient tegelijkertijd een afname van het eigen vermogen tot uitdrukking te worden gebracht. In verband hiermee wordt een controlerende positieve winst-mutatierekening negatief getrebiteerd, bijvoorbeeld 'Te realiseren dividenduitkeringen'. Betaalde dividenden kunnen op deze rekening worden afgeboekt.

Via de voorgaande boeking met betrekking tot de rentekosten over het ingebrachte eigen vermogen wordt het management wat de winstcapaciteit van het eigen vermogen van de onderneming betreft uitsluitend beoordeeld op veranderingen in het rendementspercentage 
van $15 \%$ per jaar, respectievelijk op een resultaat van meer dan Ũ $45.000 .000^{19}$. Wanneer met het (nieuwe) vermogen precies $15 \%$ rendement wordt gerealiseerd en uitgekeerd, is het saldo op de rekening 'Te realiseren dividenduitkeringen' nihil. Een negatief saldo op deze rekening betekent dat het management er niét in is geslaagd het minimaal vereiste rendement van $15 \%$ per jaar te realiseren. Nader onderzoek zal moeten uitwijzen wat de precieze oorzaken hiervan zijn. Hierna kan genoemd saldo worden overgeboekt naar de betreffende verklarende negatieve winst-mutatierekening welke rekening vervolgens op de winst-mutatiestaat wordt opgenomen.

Aan de hand van de winst-mutatiestaat kunnen ratio's worden berekend op basis waarvan men zich snel een oordeel kan vormen over de winst-veranderings-(on)mogelijkheden van een bedrijf. Te denken valt bijvoorbeeld aan de verhouding 'daling algemene rentestand/toename netto winst', de verhouding 'toename omzetvolume/toename nettowinst' of de verhouding 'afname US-Dollar/afname nettowinst'. Dergelijke ratio's geven een indicatie van de winstelasticiteil van het eigen vermogen van de onderneming.

\subsection{Differential triple-entry accounting ${ }^{20}$ ten opzichte van matrix- accounting respectievelijk relationeel accounting}

Met het gebruik van computers ten behoeve van het voeren van de bedrijfsadministratie is de matrix-accounting ${ }^{21}$ geboren (Blommaert en Blommaert, 1984:185). Wanneer een grootboek met een computer wordt bijgewerkt is het geen gebonden boek of stapel kaarten meer, maar een deel van het geheugen van een computer. In dat computergeheugen staat het grootboek niet in de (gewone of gewijzigde) scontrovorm of staffelvorm maar in matrixvorm ${ }^{22}$. Een matrix is het samenstel van een aantal regels (horizontaal) en kolommen (verticaal). Elk element (vak) uit de matrix kan uniek worden geïdentificeerd door de rij en de kolom waarvan het deel uitmaakt. Vele matrices zijn tweedimensionaal waarbij de gegevens naast en onder elkaar kunnen worden getabelleerd. In een driedimensionale matrix staan de gegevens naast, onder en achter elkaar ${ }^{23}$. Van

\footnotetext{
${ }^{19}$ Hiermee wordt aansluiting verkregen met de 'residual income'-benadering. In deze benadering is winst het 'overschot' dat resteer nadat voor het eigen, in de ondememing geïnvesteerde vermogen een adequate vergoeding is gereserveerd.

${ }^{20}$ De toevoeging 'differential' aan triple-entry accounting kan men als een tautologie beschouwen. Immers, er bestaat slechts één zuivere vorm van triple-entry accounting: differential triple-entry accounting.

${ }^{21}$ Men kan hier wellicht beter spreken van 'matrix-boekhouden' omdat het uitsluitend gaat om een andere manier van gegevensvastlegging. Inhoudelijk verandert er hierbij nauwelijks iets.

${ }^{22}$ Het vastleggen en verwerken van gegevens in matrixvorm betekent niêt dat het verstrekken van de gegevens $(x) k$ aan deze vorm is gebonden. De betreffende gegevens kunnen in de gebruikelijke overzichtsvormen worden gepresenteerd.

${ }^{23}$ Alhoewel de computer feitelijk alle gegevens achter elkaar (sequentieel) opslaat.
} 
matrices met meer dan drie dimensies kan een mens zich moeilijk een voorstelling maken maar een computer kan er zonder problemen mee werken ${ }^{24}$.

In een tweedimensionale matrix wordt een bedrag maar één keer ingevoerd. In een drieof meerdimensionale matrix worden bij de invoer van een bedrag meerdere 'bestemmingen' daarvan aangegeven, bijvoorbeeld op welke afdeling(en) het bedrag betrekking heeft, op welk(e) produkt(en), op welke activiteit(en) en/of op welk(e) project(en). Dergelijke 'doorboekingen' (allocaties) worden in een niet-geautomatiseerde administratie verricht in subadministraties casu quo afzonderlijke rubrieken en om reden van interne controle werden deze doorboekingen vaak functioneel gescheiden. De administratieve automatisering heeft er toe geleid dat het onderscheid hoofdadministratie en subadministratie casu quo sub-subadministratie is vervaagd. Via het koppelen van (cijfer)codes kunnen bepaalde doorboekingen automatisch worden doorgevoerd. Bijvoorbeeld het debiteren van een bedrag op rekeningnummer 130455, dit is de individuele klantsleutel, wordt automatisch bijgeboekt op rekeningnummer 130000 . Deze laatste rekening is de totaalrekening en wordt ook wel aangeduid als de 'collectieve rekening Debiteuren'. Een aantal doorboekingen kan worden gerealiseerd door met behulp van sorteercodes bij het inbrengen van het bedrag de rekeningen aan te geven naar welke dit (door de computer) dient te worden doorgeboekt.

Matrix-accounting dient niet te worden verward met multidimensionale accounting. Dit gevaar is niet denkbeeldig, zeker niet wanneer een multidimensionale matrix wordt gebruikt. Wanneer het traditionele accountingmodel in een omgeving van een database managementsysteem (DBMS) wordt geplaatst, ontstaat nog geen multidimensionale accounting (zoals beweerd door onder andere Drenth, 1992). Immers, dan is er bij handmatig gevoerde administraties ook sprake van multidimensionale accounting ${ }^{25}$.

Differential triple-entry accounting gaat over de selectie van de (aspecten van) financiële feiten waarover gegevens zullen worden opgeslagen en verwerkt. Dit betreft de 'scope' van gegevens: een conceptueel en derhalve inhoudelijk vraagstuk. Behalve de uitgevoerde transacties die in het conventionele systeem de 'triggers' zijn van het administratief proces, worden in differential triple-entry accounting ook de financiële gevolgen van besluiten en of gebeurtenissen geadministreerd ${ }^{26}$. Matrix-accounting is een vraagstuk

\footnotetext{
${ }^{24}$ Zo bestaat in de programmeertaal PASCAL die in de administratieve wereld veel wordt gebruikt, de mogelijkheid om in 7 dimensies te declareren.

${ }^{25}$ In een handmatig gevoerde administratie worden deze 'dimensies' voor een belangrijk deel vastgelegd via aantekeningen in subadministraties.

${ }^{26}$ Een besluit of gebeurtenis beïnvloedt de transacties die daarop volgen. Het besluit de research te halveren leidt tot lagere uitgaven, het besluit de kortingen te verhogen leidt (ceteris paribus) tot extra verkopen en het op de markt komen van een nieuwe concurrent leidt tot lagere verkopen. Door bij het vertrekpunt van het administratieve proces behalve transacties ook de gevolgen van (bedocumenteerde) besluiten en/of gebeurtenissen mee te nemen, kan aan de administratie in belangrijke mate voorspellende waarde worden toegevoegd. Zie hiervoor ook de beschrijving van
} 
over de aard van de verwerking van de gegevens: een vormtechnisch vraagstuk. Het gaat te ver om in dit verband van een nieuw 'accounting framework' te spreken (zie Leech en Mepham, 1990:6/20) ${ }^{27}$.

Een relationele database wordt door de gebruiker ervaren als een verzameling tabellen (Date, 1986:96). In een relationeel accountingsysteem worden gegevens opgeslagen in tabellen ('relations'), bestaande uit rijen en kolommen. In de rijen worden records vastgelegd en in de kolommen attributen (kenmerken). In een relationele database kunnen de kolommen worden gebruikt om relaties te leggen met een of meerdere andere tabellen. Deze relaties kunnen zelf door de gebruiker worden bepaald. Behalve het opvragen van bepaalde overzichten kan de gebruiker tevens de gegevens in zijn eigen computersysteem inladen als input bij specifieke beslissingsmodellen. Een relationeel systeem kenmerkt zich door de flexibiliteit die aan de gebruiker wordt geboden voor het vervullen van zijn specifieke informatiebehoeften. Deze flexibiliteit is mogelijk doordat de tabellen op allerlei manieren via sleutelattributen met elkaar kunnen worden gecombineerd, met andere woorden: er bestaat wat dit betreft geen vaste structuur. Dit is het belangrijke verschil tussen een relationeel accountingsysteem en een matrix-accountingsysteem waarbij dit niet per definitie mogelijk is. Maar de structuur van beide modellen is identiek. De matrix-structuur kan worden gezien als een 'interface' tussen een relationele database en de (toepassing van) accounting (Leech en Mepham, 1990:10). Ook voor relationele accounting geldt dat het belangrijke verschil met triple-entry accounting ligt besloten in de aard van de gegevens die in het systeem worden opgenomen. In differential tripleentry accounting worden additionele gegevens opgenomen over oorzaken van winstmutaties (winstkrachten) terwijl relationele accounting meestal niet meer is dan het toepassen van moderne database technologie op klassieke accountingmodellen. Hiermee is niet gezegd dat de ontwikkelingen in de automatisering aan differential triple-entry accounting volledig voorbijgaan. Het intracomptabel administreren van gegevens over winstkrachten is door de beschikbare automatisering eerder economisch verantwoord.

In het algemeen kan worden gesteld dat in het verleden maar weinig aandacht is besteed aan de vraag: dient het traditionele accountingmodel te worden aangepast wanneer dit in een geautomatiseerde omgeving wordt geplaatst? Het klassieke Pacioli-model is bijvoorbeeld niét gebaseerd op het werken met negatieve getallen. In een geautomatiseerde

\footnotetext{
het experiment in hoofdstuk 9.

${ }^{27}$ Het 'unified accounting system (UAS)' zoals dat bij de L'Oreal-groep wordt toegepast kan als cen 'tussenvorm' van matrix-accounting en triple-entry accounting worden beschouwd. De bedoeling van het UAS is de (eenmalige) gegevensinvoer dermate te herstructureren, dat een database beschikbaar is voor diverse vervolg-analyses (Stolowy et $a l, 1993: 6)$. Bij dit systcem kan uit de administratie naast de balans en resultatenrekening automatisch een kasstroom-overzicht worden opgevraagd. Hiertoe wordt bij de invoer van de gegevens een nieuwe 'dimensic' toegevoegd, zijnde de corzaak of reden van de administratieve vastlegging ('objects' genoemd). Oorzaken zijn bijvoorbeeld de opening (van het grootboek), verkopen, betalingen, inkopen, ontvangsten, emissies en aflossingen.
} 
administratie kunnen positieve en negatieve getallen probleemloos met elkaar worden verrekend. Dit aspect heeft invloed op het vertrouwde denken in 'debet' en 'credit', zijnde kolommen die Pacioli gebruikte om het optellen en aftrekken van reeksen van cijfers efficiënt te kunnen doen laten plaatsvinden. In een geautomatiseerde administratie kan in de gegevensverwerkende sfeer het onderscheid debet en credit vervallen.

\subsection{Differential triple-entry accounting, accountingmodellen en de 'events approach'}

Een accountingsysteem is een gegevensverwerkend systeem. Bij de bepaling van de aard van de gegevens en de wijze van opslag en verwerking ervan dient inzicht te bestaan in de informatiebehoeften van de beoogde systeemgebruiker. Feitelijk vormen de geïnventariseerde informatiebehoeften die uit de informatie-analyse voortkomen het vertrekpunt van de systeemanalyse (het logisch ontwerp) en het systeemontwerp (het technisch ontwerp). In traditionele accountingsystemen worden de informatiehoeften van de gebruikers, ook die van de niet op voorhand bekende gebruikers, als bekend verondersteld (de 'user need approach'). Ook de door de gebruikers gehanteerde beslissingsmodellen worden geacht bekend te zijn. Dit betekent dat men de relevante gegevens op een bepaalde wijze zal opslaan en verwerken om in deze informatiebehoeften te kunnen voorzien. In de 'events approach' van Sorter daarentegen worden gegevens zo 'ruw' (onbewerkt) mogelijk opgeslagen zodat zo veel mogelijk gegevens voor de gebruiker toegankelijk blijven (Sorter, 1969:18). De gebruiker kan dan zelf uit het betreffende gegevensbestand de gewenste gegevens opvragen, manipuleren en aan zich presenteren.

De doelstelling van de 'events approach' kan waarschijnlijk het beste worden gerealiseerd in een database-omgeving. Hierbij wordt gestreefd naar de ontwikkeling van een grote centrale gegevensbank die kan worden gebruikt door een grote groep van gebruikers met sterk uiteenlopende informatiebehoeften. Zoals in paragraaf 8.6 aangegeven, kan een dergelijk accountingsysteem als een relationeel model worden opgezet.

In aansluiting hierop zijn modellen ontwikkeld om het traditionele accountingmodel aan te passen aan de moderne informatiemethodologie en -technologie. Dit betekent onder meer dat wordt getracht de termen 'debet' en 'credit' te vervangen door universele terminologie als 'plus' en 'min', als 'in' en 'uit' of als 'bron' en 'bestemming'. Het meest bekende model in dit verband is het entiteits-relatie model ${ }^{28}$.

In een entiteits-relatie model wordt gesteld dat in een database-omgeving een accountingsysteem zijn meest natuurlijke vorm heeft wanneer dit systeem wordt gezien als:

${ }^{28}$ Ook het hierarchische model, het netwerkmodel en het wealth-income model van Ijiri kunnen hientoe worden gerekend. 
1. een verzameling van reële entiteiten met

2. de relaties tussen deze entiteiten.

De traditionele grootboekrekeningen worden in dergelijke modellen vervangen door tabellen (voor zowel de entiteiten als de relaties). In algemene zin kan een entiteitsrelatiemodel worden voorgesteld als in tabel 8.1

In het REA-model van McCarthy (1982:562) dat kan worden gezien als een generalisatie van het entiteits-relatie model, worden de voor het accountingsysteem relevante gebeurtenissen steeds in drie categorieën geanalyseerd:

1. economische bronnen (R:'resources'),

2. economische gebeurtenissen (E:'events')

en

3. economische agenten (A:'agents').

Het REA-model is feitelijk een waardenkringloopschema. Cohen-Scali noemt een door Jean-Claude Dormagen van het model van McCarthy afgeleid model, waarbij wordt gewerkt met de driedeling 'Ressource-Emploi-Objet', een 'système tradique' (CohenScali, 1990:64). Maar ook dit systeem voldoet niet aan de eisen zoals die door Ijiri zijn gesteld ten aanzien van een nieuwe, derde dimensie ${ }^{29}$.

Figuur 8.1 Het entiteits-relatie model.

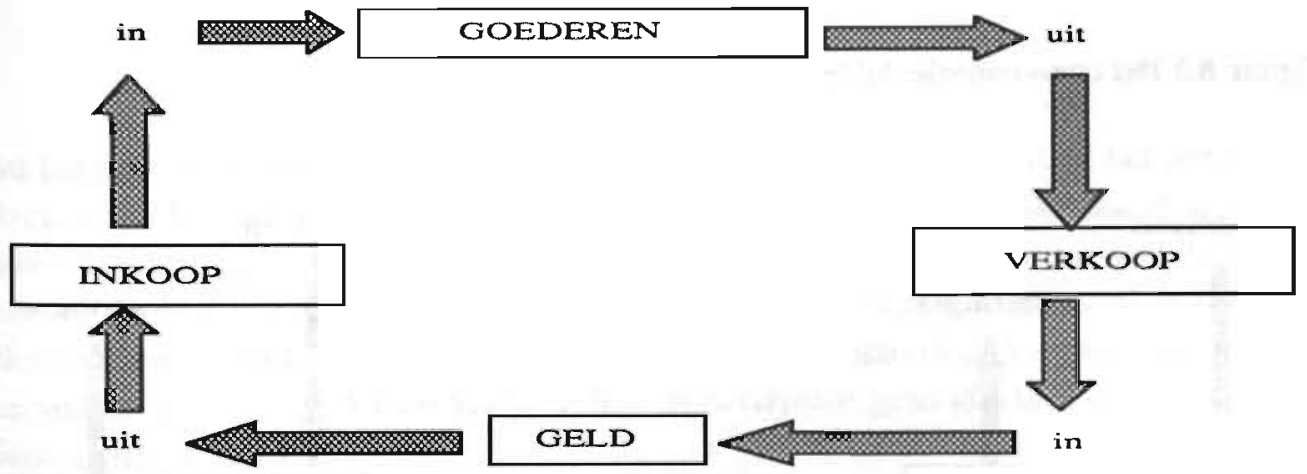

${ }^{29}$ Cohen-Scali ziet veel heil in dit model en hoopt dat het met deze 'uitvinding' de Fransen beter afgaat dan met de uitvinding van de micro-elektronica die uiteindelijk door de Amerikanen commercieel werd uitgebuil (Cohen-Scali, 1990:67). 
De 'accounting sandbox' van Thomsen (1991) kan eveneens tot het entiteits-relatie model worden gerekend. In de 'accounting sandbox' wordt een actief voorgesteld als een berg in een zandbak. Een passief wordt weergegeven als een kuil in die zandbak. Via dit model kunnen transacties op neutrale wijze worden beschreven, namelijk als het overhevelen van zand van de ene lokatie naar de andere. De 'accounting sandbox' van Thomsen is in figuur 8.2 uitgebeeld.

Figuur 8.2 De accounting sandbox van Thomsen.

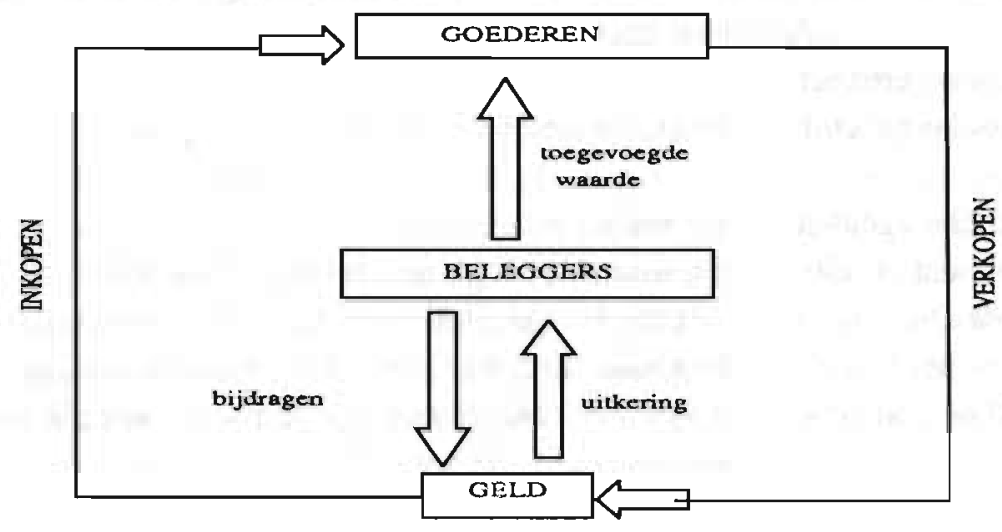

Figuur 8.3 Het conventionele dubbel boekhoudmodel.

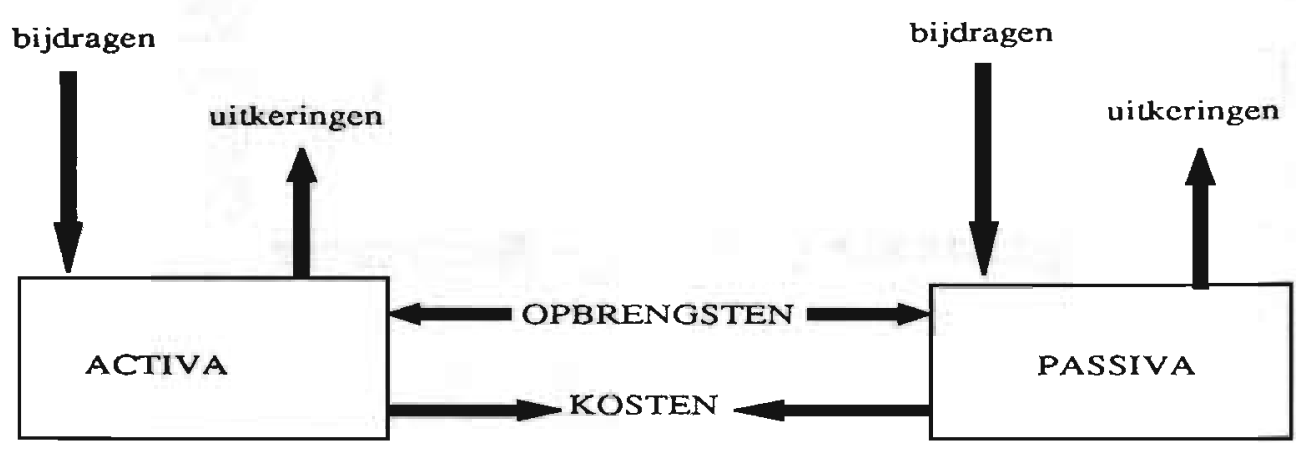


Het conventionele dubbel boekhoudmodel is in minder algemene termen beschreven omdat het zich richt op de gevolgen van transacties voor activa en passiva. Dit transactionele model, waarbij vermogenstransacties (te administreren op de rekeningen van vermogensbestanddelen) en inkomenstransacties (te administreren op de vermogensrekeningen) worden onderscheiden ${ }^{30}$, is in figuur 8.3 weergegeven (Thomsen, 1991:310).

Het 'wealth-income'-model van Ijiri is feitelijk een aanpassing van het conventionele model. Dit model ziet er als volgt uit:

Figuur 8.4 Het wealth-income-model van ljiri.

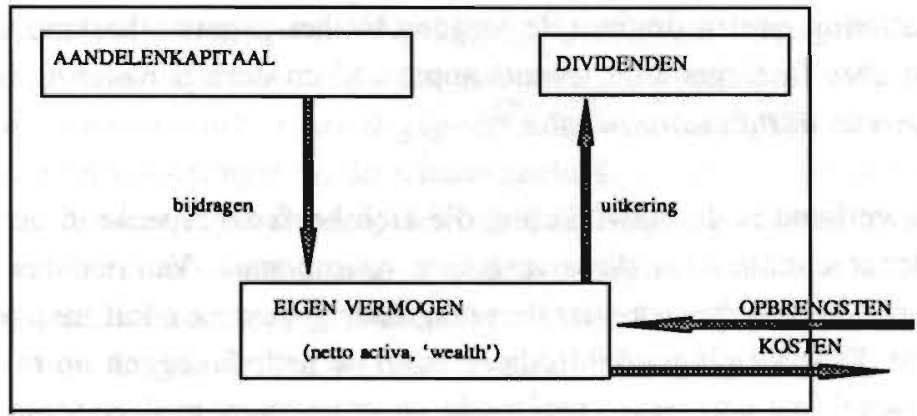

Het belangrijke voordeel van het model van Ijiri is dat dit is opgezet rond het centrale object van administratie: het eigen vermogen van de onderneming ${ }^{31}$. Met name in het dimensionale onderzoek is deze 'focus' van betekenis. Consequentie is immers dat een nieuwe, derde dimensie ook aan het eigen vermogen dient te zijn gerelateerd. Bij de afleiding van de boekingsregels voor respectievelijk temporal en differential triple-entry accounting (paragraaf 7.4.1 en 8.4.2) is deze dimensionale gebondenheid steeds het uitgangspunt geweest.

\footnotetext{
${ }^{30}$ Vermogenstransacties, zoals inkopen van goederen en ontvangen aflossingen, beïnvloeden uitsluitend de samenstelling van het eigen vermogen. Ijiri duidt vermogenstransacties aan als 'intra-wealth-transactions' (1982:13). Ook worden hiertoe gerekend de mutaties in het eigen vermogen ten gevolge van financieringsactiviteiten en winstverdeling. ljiri duidt deze transacties aan als 'intra-capital-transactions'. Inkomenstransacties, betreffende winstbepalende activiteiten zoals het verkopen van goederen en het verhuur van onroerende zaken, beïnvloeden de omvang van het eigen vermogen. Ijiri spreekt hier van 'wealth-capital-transactions'. Zie ook paragraaf 8.4.2.

${ }^{31}$ Men kan immers ook een ander object kiezen zoals bijvoorbeeld in niet-commerciele bedrijfshuishoudingen het inkomen.
} 
Vanuit een informatica-oogpunt zijn zowel het conventionele accountingmodel als het wealth-income-model van Ijiri onvoldoende universeel. Deze universaliteit is van belang bij 'events accounting' opdat de gegevens op een dusdanige wijze kunnen worden opgeslagen dat deze door verschillende gebruikersgroepen kunnen worden gebruikt voor het voorzien in de eigen specifieke informatiebehoeften.

Het verschil tussen de 'events approach' (of 'events accounting') en triple-entry accounting ligt net als bij matrix-accounting op het terrein van de vulling van het gegevensbestand. Triple-entry accounting is een vraagstuk aan de basis van het informatiesysteem: Over welke (aspecten van) financiële feiten zullen gegevens in het systeem worden ingevoerd? Wanneer vervolgens ten aanzien hiervan een bepaald standpunt is ingenomen, kan men een beslissing nemen omtrent de toegang tot het gegevensbestand voor de gebruiker. Pas in deze fase speelt de 'events approach' en deze benadering is derhalve meer een kwestie van bestandsorganisatie ${ }^{32}$.

Interessant in dit verband is de ontwikkeling die zich heeft afgespeeld in de wereld van bibliotheek en documentatie waar dienstverlening voorop staat. Van oudsher begrepen de beroepsbeoefenaren in deze branche dat de vraag naar gegevens nooit met zekerheid kan worden voorspeld. Daarom gingen bibliothecarissen de nadruk leggen op toegankelijkheid en brachten een scheiding aan tussen registratie en rapportage, in deze sector postcoordinatie genoemd. Met beleid worden gegevens verzameld als algemene grondstof terwijl waarborgen worden ingebouwd voor specifieke informatiebehoeften, zelfs voor behoeften die niet bekend waren toen de gegevens werden verzameld. De eisen aan informatievoorziening voor enerzijds beheer en anderzijds verantwoording worden zo in een enkel model verzoend (Wisse, 1992:41). Men zou kunnen stellen dat de postcoördinatie in deze sector heeft geleid tot een bepaalde applicatie van de 'events approach, 33 .

Men kan de vraag stellen waarom het zolang heeft geduurd (op de kop af 500 jaar) om van Pacioli via Ijiri tot deze dissertatie te komen en derhalve van dubbel boekhouden naar een drievoudige administratie. Het antwoord hierop ligt waarschijnlijk besloten in de diepgang waarmee ljiri zijn werk heeft onderbouwd, met name voor wat betreft de accountingmethodologie (Cooper en Kozmetsky, 1992:1). Maar een ander aspect is mijns inziens dat ljiri de praktische implementatie van (differential) triple-entry accounting

\footnotetext{
${ }^{32}$ Overigens is deze stelling in tegenspraak met de bewering van $C$ ushing die stelt dat 'Ijiri's concept of multidimensional accounting is not dissimilar to the events approach' (1989:32).

${ }^{33}$ Wisse gebruikt in zijn artikel de term 'relationeel boekhouden'. Hiermee bedoelt hij de synthese tussen een commercieel en kameralistisch boekhoudstelsel (Wisse, 1992:43). In het kader van de administratieve automatisering is deze aanduiding misleidend.
} 
onvoldoende heeft uiteengezet, respectievelijk daaraan nog niet is toegekomen. De in dit hoofdstuk besproken case moge dit hiaat (enigszins) hebben opgevuld.

\subsection{Samenvatting}

In geval van de in dit hoofdstuk beschreven vorm van differential triple-entry accounting wordt verondersteld dat de winstsnelheid van het eigen vermogen van een onderneming ('income momentum') die in een bepaalde periode is gerealiseerd, ook in de volgende verslagperiode kan worden gerealiseerd. Concreet betekent dit een unieke intracomptabele integratie van het differential triple-entry accountingsysteem en het momentum accountingsysteem zoals beide ontwikkeld door Ijiri. Op basis van deze integratie kunnen de voordelen van beide systemen tegelijkertijd worden behaald, dat wil zeggen: in het administratieve systeem worden zowel gegevens inzake oorzakelijke winstmutaties als gegevens inzake ontwikkelingen in de winstcapaciteit van de onderneming vastgelegd. Het triple-entry financieel informatiesysteem (bij dit 'constant income momentum'postulaat) administreert de veranderingen in deze winstsnelheid. In afwijking van een dubbel boekhoudstelsel betekent dit onder meer dat intracomptabel de financiële effecten van ontwikkelingen in grootheden worden vastgelegd als bijvoorbeeld rentepercentages, ziekteverzuim, prijzen van grondstoffen, lonen en/of eindprodukten, volume-aanpassingen en verwachte winsteffecten van overheidsmaatregelen, concurrenten of eigen marktinspanningen. Op basis van zo'n administratie kan een sluitende verklaring worden gegeven voor een ten opzichte van de vorige verslagperiode afwijkend winstniveau ${ }^{34}$. Een gefundeerde(r) beoordeling van de ondememingsprestaties en -positie zijn hierbij mogelijk omdat de veranderingen in winstkrachten kunnen worden geadministreerd: - naar herkomst (intern/extern);

- naar hun termijn-effect op het ondernemingsresultaat (structureel/ incidenteel). Dit maakt voorspelling van de ondernemingwinst beter en sneller mogelijk.

Een drie-dimensionale administratie kan een belangrijk middel zijn in het kader van optimalisering van de financiële stuur- en/of verantwoordingsinformatie-kringloop in en rondom een organisatie. Dit hoofdstuk beoogde de mogelijke plaats van een drie-dimensionaal accountingsysteem in dit proces te schetsen. De derde dimensie, zijnde de oorzakelijke winstmutatie, kan intracomptabel worden geadministreerd door in het grootboek enerzijds 'controlerende winst-mutatierekeningen' aan te leggen en anderzijds 'verklarende winst-mutatierekeningen'. Op het eerste type rekeningen worden realisaties

\footnotetext{
${ }^{34}$ In dit opzicht kan differential triple-entry accounting als een vorm van 'activity based accounting' worden aangemerkt omdat wordt getracht het oorzakelijk verband tussen winst en winstkrachten zo goed mogelijk weer te geven.
} 
van de 'income momentum' vastgelegd. Op het tweede type rekeningen worden veranderingen in de 'income momentum' geadministreerd.

Een systematisch overzicht van de invloed op de winst van winstkrachten, de winst-mutatiestaat, kan om diverse redenen van belang zijn. Met name is dit het geval bij de beoordeling door een gebruiker van de jaarrekening en de inschatting van de (on)mogelijkheden van het bedrijf op langere termijn. Men mag aannemen dat het beschikbaar stellen van een winst-mutatiestaat de 'voorspellende waarde' van de verstrekte gegevens doet toenemen ${ }^{35}$.

Behalve in de sfeer van de informatiewaarde van de jaarrekening ('decision relevance') kunnen ook voordelen in de verantwoordingssfeer ('accountability'-effecten) worden verwacht. Indien bijvoorbeeld de effecten van overnames op omzet en winst expliciet in een afzonderlijk overzicht worden gepresenteerd, kan dit de neiging onderdrukken deze acties ook in de manipulatieve sfeer toe te passen. Bovendien kan de winst-mutatiestaat op korte termijn winstgevende acties ontmoedigen wanneer deze worden uitgevoerd ten laste van de winstsnelheid van het eigen vermogen en derhalve van de toekomstige winstmogelijkheden van het bedrijf (in dit geval toont de winst-mutatiestaat een daling van de 'income momentum' terwijl de resultatenrekening een toename van de winst laat zien). Ook met betrekking tot management-beloningssystemen ('bonus plans') is informatie omtrent winstkrachten van belang. Immers het management kan sneller worden afgerekend op de (verwachte) resultaten van haar beleid omdat de gevolgen van haar acties direct in de ontwikkeling van de 'income momentum' worden geëxpliciteerd.

$\mathrm{Bij}$ het administreren van winstkrachten kunnen de nodige waarderingsvraagstukken ontstaan. Bovendien zal de administratieve organisatie moeten worden aangepast. Deze dient er voor zorg te dragen dat de betreffende gegevens voor de afdeling administratie beschikbaar komen. Maar de problematiek in dezen verschilt niet wezenlijk van die bij de ontwikkeling van het enkel boekhouden naar het dubbel boekhouden naar de aard en inhoud van de hedendaagse financiële verslaglegging.

In figuur 8.5 is tot slot een sterk vereenvoudigde administratieve procesgang afgebeeld zoals dic plaatsvindt bij toepassing van (differential) triple-entry accounting. Uit deze figuur blijkt dat bij toepassing van dit systeem de basis van het accountingmodel verandert, dat wil zeggen: het bestand van de te administreren financiële feiten wordt uitgebreid. Behalve over de gevolgen van transacties worden ook gegevens verwerkt over de gevolgen van bepaalde besluiten en gebeurtenissen. Deze uitbreiding van de gegevensverzameling en -verwerking is noodzakelijk met het oog op de te administreren nieuwe, derde dimensie: (oorzakelijke) winstmutaties.

${ }^{35}$ In hoofdstuk 9 wordt deze veronderstelling getest. 
Figuur 8.5 Administratieve procesgang bij toepassing van (differential) triple-entry accounting.






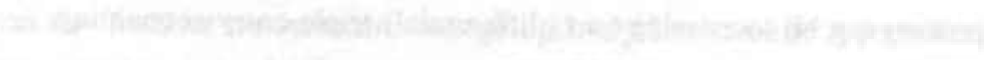

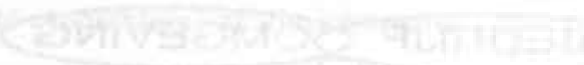

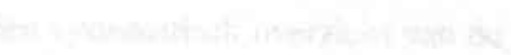




\section{Beslissingsrelevantie van triple-entry en mo- mentum-accounting; verslag van een experiment}

"Accounting laboratory experiments in human judgment will be an increasingly important element of future accounting research" (Snowball, 1986:63).

\subsection{Inleiding; typering van het experiment}

Het doel van het experiment waarvan de resultaten in dit hoofdstuk worden besproken, was het verzamelen en analyseren van gegevens over de invloed van een drie-dimensionale gegevensverstrekking op de besluitvorming van bepaalde gebruikers (in dit geval controllers). Met andere woorden: het experiment had als doel het testen van de beslissingsrelevantie van triple-entry en momentum accounting. Vergelijkbare experimenten zijn reeds eerder uitgevoerd, onder andere door Dyckman (1964) bij een onderzoek naar de invloed van verschillen in waardering (fifo versus lifo) op bepaalde beslissingen van het management, door McIntyre (1973) bij een onderzoek naar het effect van gegevens over actuele waarde op beleggingsbeslissingen en door DeJong et al (1989) bij een analyse naar de effectiviteit en efficiency van verschillende soorten transferprijzen.

In het algemeen worden twee typen experimenten onderscheiden, het laboratoriumexperiment en het veldexperiment.

Het laboratorium-experiment als onderzoekmethode bij menselijke beoordelingen wordt in de accounting op steeds grotere schaal toegepast (Swieringa en Weick, 1983:88; Snowball, $1986: 49)^{1}$. Een laboratorium-experiment is hierbij gekarakteriseerd als een onderzoek (1) waarbij de onderzoeker een (of enkele) onafhankelijke variabele(n) manipuleert teneinde de impact hiervan te meten op een (of enkele) afhankelijke variabele(n) en (2) dat wordt uitgevoerd in een fysieke situatie die afwijkt van de dagelijkse gang van zaken. Swanborn (1987:230) definieert een laboratorium-experiment als een experiment waarbij individuele personen die elkaar niet of nauwelijks kennen worden uitgenodigd om naar een laboratorium te komen om aldaar deel te nemen aan een onderzoek met een psychologische, sociaal-psychologische of onderwijskundige probleemstelling. Een veldexperiment daarentegen wordt gedaan in de natuurlijke omgeving van de proefpersonen waarbij de betrokken personen meestal niet weten dat zij in een onderzoek zijn betrokken.

\footnotetext{
'Dit gebeurt vooral op het terrein van de 'human judgment', in het bijzonder ten aanzien van beoordelingen door managers. Gemeten naar het aantal publikaties in de top van de vaktijdschriften was in de periode 1964-1966 het aantal laboratorium-experimenten 4 ofte wel 1,5\% van alle artikelen. In de periode 1982-1984 was dit aantal uitgegroeid naar 36 studies, zijnde 14,8\% van alle artikelen (Snowball, 1986:49).
} 
Ten behoeve van het testen van de beslissingsrelevantie van triple-entry en momentum accounting is een laboratorium-experiment uitgevoerd. Hierop is de response van twee groepen (een experimentele groep en een controle-groep) van cursisten aan de postdoctorale controllers-opleiding met elkaar vergeleken. De meeste van deze cursisten waren tevens in de praktijk werkzaam ${ }^{2}$. Gezien de voorgaande omschrijvingen en de geselecteerde proefpersonen kan in dit geval het uitgevoerde experiment eerder als een laboratorium-experiment dan als een veldexperiment worden beschreven. Het is een onderzoek tussen twee (groepen van) subjecten, met uitsluitend meting achteraf ${ }^{3}$.

Bij het gebruik van cursisten als proefpersonen voor het beoordelen van de managementrelevantie van triple-entry en momentum accounting, bestaat het probleem dat de onderzoeksresultaten niet zonder meer kunnen worden geldig verklaard voor de beoogde gebruikers, in dit geval managers (dit is het probleem van de externe validiteit). Cursisten zijn (nog) geen managers. Maar dat dit aspect de onderzochte relaties in deze studie in belangrijke mate heeft beïnvloed, ligt niet voor de hand ${ }^{4}$. Ook het feit dat proefpersonen in een experiment zich vaak anders gedragen omdat ze weten dat hun gedrag wordt geanalyseerd, is voor dit onderzoek minder valide. Dit is immers een inherent aspect van elk accountingsysteem (Swieringa en Weick, 1983:87).

Verschillen in uitkomsten tussen de groepen kunnen deels zijn veroorzaakt door verschillen in persoonlijkheid voor wat betreft de wijze van gegevensverwerking. Maar de invloed van deze factor is slechts zeer beperkt (zie bijvoorbeeld McGhee et al, 1978:681).

\subsection{Profielschets van de experiment-deelnemers}

Aan het experiment hebben in totaal 36 proefpersonen - eerste-jaars controller in opleiding - deelgenomen. Hiervan studeerden 20 deelnemers aan de postdoctorale opleiding tot (register)controller van de Rijksuniversiteit Limburg (RL) terwijl 16 deelnemers de zelfde opleiding volgden aan de Vrije Universiteit Amsterdam (VUA) ${ }^{5}$. Aldus werd ruim 34\% van het totale aantal studerende eerste-jaars controllers per het moment van het experiment (juni/september 1993) in het onderzoek betrokken.

\footnotetext{
${ }^{2}$ Het gehnik van cursisten als 'proefpersonen' is in dit verband overigens gemeengoed. In het door Snowball uitgevoerde onder/vek bleck dat in 70 $:$; van de in de periode 1964-1984 uitgevoerde relevante laboratoriumexperimenten, cursisten als proefpersonen waren ingezel. Echter, de laatste jaren worden relatief stecds meer andere typen proxipersonen gebruikt, zoals accountints (Snowball, 1986:50).

${ }^{3}$ Volgens Snowball wordt deze handelswijze in bijna $50 \%$ van de laboratorium-experimenten gevolgd (Snowball, 1986:50).

${ }^{4}$ Behalve het kwalitaticve niveau van de controllers-opleiding is dexe verwachting mede ingegeven door het feit dat de betreffende cursisten alle reeds in de praktijk werkzaam waren.

${ }^{5}$ In dit verband ben ik Prof. HL. Brink RA en Prof. Dr. L. Tratas zeer erkentelijk voor de geboden mogelijkheden.
} 
Om de kans te minimaliseren dat in de ene groep (bijna) alle 'coöperatieven' zitten en in de andere groep (bijna) alle 'tegenwerkers', is een minimale omvang van 20 personen per groep gewenst (Swanborn, 1986:242). Om deze factor te kunnen beoordelen, is de deelnemers naar hun bereidheid tot deelname aan het experiment gevraagd ${ }^{6}$.

Het merendeel van de respondenten (ruim 63\%) was in een administratieve functie respectievelijk in een accountingfunctie werkzaam. Slechts één respondent was specifiek in de financiering werkzaam, geen enkele respondent functioneerde hoofdzakelijk op het gebied van de treasury. In totaal 8 respondenten gaven aan in meerdere of mindere mate een management-functie te bekleden. De gemiddelde duur dat de proefpersonen in hun huidige functie werkzaam waren, bedroeg 1,2 jaar (met een uitschieter van 6,5 jaar).

Op een schaal van 1-10 bedroeg de gemiddelde bereidheid om aan het experiment deel te nemen 7,22 en verschilde nauwelijks onder de in het experiment onderscheiden groepen. Niemand van de deelnemers had enige voorkennis inzake triple-entry en/of momentum accounting.

Inclusief nabespreking duurde het experiment bijna 2 uur. Een extrinsieke beloning voor deelname aan het experiment werd niét in het vooruitzicht gesteld.

\subsection{Opzet van het experiment}

De deelnemers van zowel de VUA als de RL zijn in twee groepen van gelijke omvang gesplitst: een groep die op basis van het conventionele accountingsysteem haar standpunten moest bepalen (groep D) en een groep die dit moest doen op basis van een driedimensionale informatievoorziening (groep T). Aldus is uiteindelijk de standpuntbepaling van twee groepen van 18 personen met elkaar vergeleken. Ter voorkoming van 'selectieeffecten' werd via loting bepaald of een proefpersoon tot groep D dan wel tot groep T behoorde. Ook de proefleiders werden volgens toeval aan de groepen toegewezen.

De case die aan de proefpersonen werd voorgelegd, komt voor een belangrijk deel overeen met de CLM-case zoals die in hoofdstuk 8 is besproken. Voor een goede orde is de case zoals aan beide groepen voorgelegd, achter in het boek opgenomen in bijlage $9 \mathrm{~A}$ (zoals voorgelegd aan groep D) respectievelijk in bijlage 9B (zoals voorgelegd aan groep T) bij dit hoofdstuk.

\footnotetext{
${ }^{6}$ Het experiment op de RL was zodanig aangekondigd en gepland dat niet geheel van een 'vrijwillige declname" kan worden gesproken. Derhalve kan deze groep niet zonder meer als coöperaticf worden aangemerki. Overigens week de response van deze groep niét significant af van de response van de VU-groep.
} 
Voordat aan groep $\mathrm{T}$ de case werd voorgelegd, is aan deze groep eerst schriftelijke informatie verstrekt over de aard en inhoud van de derde, nieuwe dimensie casu quo de hierbij behorende winst-mutatiestaat. De betreffende tekst is in bijlage $9 \mathrm{C}$ bij dit hoofdstuk opgenomen. De leestijd voor deze tekst bedroeg 10 minuten. Vervolgens werd ook aan deze groep de case uitgereikt (zie bijlage 9B bij dit hoofdstuk).

Bij de case werd een set van vragen voorgelegd. Deze vragenlijsten zijn opgenomen in respectievelijk bijlage 9D (voor groep D) en bijlage 9E (voor groep T) bij dit hoofdstuk. Alle deelnemers hadden voor de beantwoording van de vragen één uur de tijd (rekening houdend met de leestijd van 10 minuten voor groep $\mathrm{T}$ voor de inleidende tekst, bedroeg de beschikbare tijd voor deze groep netto 50 minuten). Voor de beantwoording van vraag 1 van de vragenlijst werd de deelnemers gevraagd zelf de verbruikte tijd te registreren (zie vraag 2).

De gemiddelde score voor het realiteitsgehalte van de voorgelegde case was 6,31. Dit als 'voldoende' te kwalificeren cijfer is van groot belang omdat in het geval van een (te) lage waardering van het realiteitsgehalte van de case de deelnemers de neiging hebben een soort 'spelgedrag' te vertonen ten gevolge waarvan de uitkomsten minder betrouwbaar worden (Birnberg en Nath, 1968:42). Opvallend hierbij was dat de scores voor beide groepen nogal verschillend waren. Voor groep D bedroeg de gemiddelde score 5,87 en voor groep T 6,67 (bij een standaarddeviatie van respectievelijk 1,13 en 1,37). Het is mogelijk dat dit effect voor groep $T$ wordt opgeroepen door de beschikbaarheid van de gegevens inzake de derde dimensie (de extra gegevens doen de geloofwaardigheid toenemen), dan wel dat groep D enigszins werd teleurgesteld doordat deze bij het doornemen van de case geen 'vernieuwing' constateerde (met kennelijk het minder uitdagende gevoel van controlegroep te zijn) ${ }^{7}$. Bij een betrouwbaarheidsinterval van $95 \%$ is het geconstateerde verschil in waardering van het realiteitsgehalte van de case significant (p-waarde $3,75 \%$ ).

\subsection{Onderzoeksresultaten}

Het experiment is in hoofdzaak opgezet voor het verkrijgen van inzicht in de beslissingsrelevantie van triple-entry en momentum accounting. Een centrale vraag is immers of op basis van een dergelijk administratief systeem de gebruikers tot kwalitatief betere beslissingen kunnen komen. In dit verband is de volgende (nul)hypothese getest:

\footnotetext{
${ }^{7}$ Bij de uitnodiging voor het experiment en ook voordat de deelnemers aan de groepen D respectievelijk $T$ werden toegewezen, werd hen verteld dat de bedoeling van het experiment was het uittesten van de kwaliteit van een nieuw accounting-informatiesysteem.
} 
In vergelijking met een conventioneel ('double-entry') accountingsysteem neemt bij toepassing van triple-entry en momentum accounting de kwaliteit van op deze gegevens gebaseerde beslissingen (voorspellingen) niét significant toe ${ }^{8}$.

In de eerste plaats gaat het bij de beoordeling van de kwaliteit van de beslissing om de vraag in hoeverre de experiment-deelnemers in staat zijn om op basis van de verstrekte gegevens te komen tot de juiste winstvoorspelling. Men kan dit aanduiden als de nauwkeurigheid van de voorspelling. Hiertoe is voor de verschillende groepen de afwijking bepaald van de daadwerkelijke winstvoorspelling ten opzichte van de genormeerde winstvoorspelling ad U $59.850 .000^{9}$. Het protocol van de voor CLM genormeerde winstvoorspelling is in tabel 8.1 opgenomen in paragraaf 8.3 , respectievelijk in tabel 8.4 opgenomen in paragraaf $8.4 .2^{10}$.

De gemiddelde waarde van de voorspelling bedroeg voor de groep met de conventionele gegevens (groep D) Ũ 41.396.944 en voor groep T Ũ 57.072.222 (bij een standaarddeviatie van respectievelijk Ũ 58.104.892 en Ũ 35.597.398). Dit betekent dat voor beide groepen het saldo van de gemiddelde reële afwijking negatief is (voor beide groepen respectievelijk - U 18.453.056 en - U 2.777.778). Dit kan duiden op beïnvloeding van de respondenten door de waarden (en het verloop) van de winstcijfers over 1991 en 1992 (het 'anchoring'-verschijnsel). Het verschil in response tussen beide groepen is bij een significantienorm van $5 \%$ evenwel niét significant (tweezijdige p-waarde $21,96 \%)^{11}$.

Voor groep D bedroeg de gemiddelde absolute afwijking ten opzichte van de genormeerde voorspelling Ũ 44.703 .056 bij een standaarddeviatie van Ũ 40.259.286. Voor groep T bedroeg deze afwijking gemiddeld $\tilde{U} \mathbf{1 3} .716 .667$ bij een standaarddeviatie van $\tilde{U}$ 32.804.425. Derhalve kwam groep $T$ in dit opzicht tot een aanzienlijk nauwkeuriger voorspelling. Het waargenomen verschil in gemiddelde is bij een significantienorm van $5 \%$ significant (p-waarde $0,4 \%$ ). In groep D kwam slechts 1 deelnemer tot de genormeerde voorspelling terwijl dit in groep $T$ in totaal 8 deelnemers lukte.

\footnotetext{
${ }^{8}$ Men kan stellen dat de kwaliteit van beslissingen niét met behulp van een laboratorium-experiment kan worden getest vanwege het ontbreken van cen objectieve normering voor de beoordeling van de response. In deze visie kan de hypothese zoals hier geformuleerd als volgt worden geïnterpreteerd:

'Bij toepassing van triple-entry en momentum accounting zijn gebruikers niét in staat de verstrekte drie-dimensionale gegevens in hun besluitvorming te integreren'. Wat hier dan feitelijk wordt getest, is het aspect van de hanteerbaarheid van de verstrekte gegevens (zic ook paragraaf 9.5).

${ }^{9}$ Feitelijk bestaat er ten aanzien van voorspellingen geen absoluut nulpunt. De beste voorspelling is immers die voorspelling die achteraf uitkomt respectievelijk het minst is verwijderd van de daadwerkelijke uitkomst.

${ }^{10}$ Alle hierna geschetste verhoudingen zijn ook per universiteit geanalyseerd zodat 4 groepen zijn onderzocht. Hierbij zijn geen resultaten aan het licht gekomen die aanleiding gaven tot enige terughoudendheid bij het samenvoegen der groepen.

${ }^{11}$ Hierbij is gelet op de aard der gegevens de Wilcoxon-Mann-Witney test uitgevoerd (betrouwbaarheidsinterval 95\%).
} 
Het kan zijn dat door de onbekendheid met het driedimensionale systeem een aantal deelnemers in groep $\mathrm{T}$ bij het doen van de winstvoorspelling is teruggevallen op voor hen bekende oplossingsstrategieën ${ }^{12}$. Derhalve hebben deze deelnemers zich gedragen als behoorden zij tot groep D. In verband hiermee kan nog een beter inzicht in het verschil in response worden verkregen wanneer uit groep $\mathrm{T}$ de deelnemers'worden gelicht die volgens het door hen opgestelde protocol de quintessens van triple-entry en momentum accounting niet hebben doorgrond ${ }^{13}$. Vervolgens zijn de resultaten van de aldus gecorrigeerde groep T (15 deelnemers) vergeleken met de resultaten van groep D (18 deelnemers). De gemiddelde absolute afwijking in de gecorrigeerde en gehomogeniseerde groep $\mathrm{T}$ bedroeg $\tilde{\mathrm{U}} 8.670 .000$ bij een standaard-afwijking van U 22.926.597. Het verschil in response bij de thans gehanteerde vergelijking is extra significant ( $\mathrm{p}$-waarde $0,22 \%$ ). Wanneer groep $\mathrm{T}$ zoals hiervoor aangegeven wordt gecorrigeerd, is de gemiddelde reële afwijking van de voorspelling in deze groep positief (in casu Ũ 4.456.667).

Wanneer de nauwkeurigheid van de voorspelling als belangrijkste graadmeter voor de kwaliteit ervan geldt, dient de hiervoor geformuleerde hypothese te worden verworpen. Anders gezegd: triple-entry accounting verbetert de kwaliteit van de beslissingen (voorspellingen) aanzienlijk ${ }^{14}$.

Een ander kwaliteits-aspect dat kan worden gemeten is de tijdsduur welke is benodigd om tot de winstvoorspelling te komen. De gemiddelde benodigde tijdsduur voor groep D bedroeg bijna 36 minuten en voor groep T ruim 25 minuten (bij een standaarddeviatie van respectievelijk $91 / 2$ minuut en 7 minuten). Het aldus geconstateerde verschil in tijd is significant (eenzijdige p-waarde 0,05\%).

Bij deze uitkomsten dient te worden bedacht dat groep $\mathrm{T}$ voor het bestuderen van de case extra tijd zal hebben verbruikt vanwege de onbekendheid met de winst-mutatiestaat (de voor het lezen van dit overzicht gemiddeld benodigde tijd bedroeg 12,33 minuten).

Wanneer voor groep $T$ wordt uitgegaan van de netto verbruikte tijd (= verbruikte tijd tijd benodigd voor interpretatie winst-mutatiestaat), dan is het verschil in response extra significant (p-waarde 0,0001\%).

Een ander aspect dat is getest betreft het vertrouwen dat de deelnemers hadden in hun eigen voorspelling. Het gemiddelde cijfer (op een schaal van 1-10) voor het vertrouwen

\footnotetext{
${ }^{12}$ Dit is het bekende verschijnsel van de 'functionele fixatie' en de 'local search'.

${ }^{13}$ Wanneer in het geheel geen gebruik werd gemaakt van de winstsnelheid van het eigen vermogen zoals die per 31 december 1992 was gegeven, kan worden verondersteld dat de quintessens van het nieuwe informatiesysteem niet is doorgrond. Het betrof hier in total 3 respondenten.
}

${ }^{14} \mathrm{Het}$ is in ieder geval zo dat gebruikers op efficiẻnte wijze de verstrekte drie-dimensionale gegevens in hun besluitvorming hebben kunnen betrekken en als zodanig kan worden gesteld dat dergelijke gegevens goed hanteerbaar zijn (zie cok de opmerkingen in voetnoot 8). 
van groep D lag op 7,25 en voor groep $T$ op 5,95 (bij een standaarddeviatie van respectievelijk 1,51 en 1,98). Hier scoort triple-entry en momentum accounting derhalve aanzienlijk slechter dan conventionele accounting. Het verschil in response is significant (p-waarde 1,66\%). In wezen is dit een irreële uitkomst omdat bij triple-entry en momentum accounting een belangrijk deel van het proces van een winstvoorspelling reeds systematisch is doorlopen ${ }^{15}$. De hier gevonden uitkomsten dienen dan ook te worden gesteld tegen de achtergrond van de onbekendheid van groep $\mathrm{T}$ met het nieuwe informatiesysteem.

Op een schaal van 1-10 waardeerde groep D de prestatie van het management in 1992 gemiddeld met een 5,83 (standaardafwijking 1,43). Voor groep T lag deze beoordeling op gemiddeld 6,03 (standaardafwijking 1,50). De gemiddelde beoordeling in groep $\mathrm{T}$ kan als 'iets beter' worden bestempeld omdat, zoals in hoofdstuk 8 is uiteengezet, de winst van CLM weliswaar is afgenomen van Ũ 122.000 .000 naar Ũ 85.000.000, maar de winstcapaciteit van het eigen vermogen per 31-12-1992 (de income momentum) is toegenomen van Ũ 85.000 .000 tot Ũ 150.000 .000 . De geconstateerde verschillen zijn geenszins significant (p-waarde $41,43 \%)^{16}$. De deelnemers in groep $\mathrm{T}$ baseerden hun waardering voor een belangrijk deel op de in 1992 gecreëerde structurele winstmogelijkheden voor de toekomst, de income momentum derhalve. In totaal gaven 12 van de 18 respondenten aan dit aspect van doorslaggevende betekenis te vinden. In groep D gaven 4 van de 18 respondenten dit expliciet aan hetgeen wijst op het belang dat ook deze groep hechtte aan de ontwikkeling in de income momentum. Slechts 3 proefpersonen uit groep D baseerden hun oordeel op de in 1992 gerealiseerde winst ten opzichte van de in 1991 behaalde winst.

Om een mogelijk gedragseffect van triple-entry en momentum accounting te meten is de deelnemers ook de vraag voorgelegd of ze bereid waren hun toevlucht te zoeken tot 'creatief boekhouden' ten einde de financiële prestatie van de onderneming over 1992 te verbeteren. De te testen (nul)hypothese in dit verband was:

In vergelijking met een conventioneel ('double-entry') accountingsysteem gedraagt een agent zich bij toepassing van triple-entry accounting in de ogen van de principaal niét significant meer verantwoord.

Gezien het feit dat de winst van CLM in 1992 weliswaar is teruglopen maar dat de income momentum aanzienlijk is toegenomen, zou men kunnen verwachten dat de deelnemers in groep $\mathrm{T}$ minder reden zouden zien om te manipuleren. Bovendien wordt

\footnotetext{
${ }^{15}$ Een analyse van de protocollen van de winstvoorspelling van de deelnemers uit groep D laat zien dat de verwerking van de gegevens met betrekking tot de winstvoorspelling die in het conventionele systeem min of meer ad hoc en informeel plaatsvindt, in het triple-entry accountingsystcem stelselmatig en systematisch wordt uitgevoerd.

${ }^{16}$ Hetgeen werd bevestigd door de Kolmogorov-Smirnov two-sample test.
} 
via een triple-entry en momentum accountingsysteem een aantal manipulaties direct zichtbaar doordat bijvoorbeeld de winst wordt opgehoogd ten laste van de income momentum waarmee de toekomstige winstmogelijkheden worden geschaad.

In totaal antwoordden 9 deelnemers op bedoelde vraag bevestigend waarvan 4 in groep T. Het verschil in beide groepen is niét significant (p-waarde 14,39\%) zodat bovenstaande hypothese dient te worden verworpen. Uit groep T wezen 6 van de 18 deelnemers expliciet op het feit dat bij de voorgestelde alternatieve verwerking van de reorganisatiekosten de winst over 1992 weliswaar zou toenemen maar dat de winstcapaciteit (income momentum) gelijk zou blijven. Derhalve miste het voorstel van de collegae-bestuursleden doeltreffendheid.

De uitgevoerde enkelvoudige correlatie-test ${ }^{17}$ gaven in een aantal gevallen significante uitkomsten. Naarmate de deelnemers meer praktijk-ervaring hadden, daalde de tijd die was benodigd voor de winstvoorspelling (correlatiecoëfficiënt -0.3288 bij een p-waarde van $2,7 \%$ ). Naarmate de deelnemers meer ervaring hadden, steeg de waardering voor het realiteitsgehalte van de case (correlatiecoëfficiënt 0,2659 bij een p-waarde van $7,05 \%$ ). De absolute afwijking nam toe wanneer de voor de winstvoorspelling benodigde tijd toenam (correlatiecoëfficiënt 0,3547 bij een p-waarde van $1,7 \%)^{18}$. Bereidheid tot deelname aan het experiment en vertrouwen in de gedane winstvoorspelling waren positief gecorreleerd (correlatiecoëfficiënt 0,2368 bij een p-waarde van $8,55 \%$ ). Naarmate de absolute afwijking ten opzichte van de genormeerde winstvoorspelling toenam, daalde de waardering voor het door CLM in 1992 bereikte resultaat (correlatiecoëfficiënt $-0,35$ bij een p-waarde van $1,8 \%$ ).

Ook is een aantal meervoudige regressie-analyses uitgevoerd, zoals tussen nauwkeurigheid van de voorspelling enerzijds en vertrouwen in de voorspelling en de waardering voor de financiële performance van de onderneming anderzijds. In alle onderzochte situaties was geen sprake van significante associaties ${ }^{19}$.

De uitkomsten van het regressie-onderzoek zijn van dien aard dat deze de eerder getrokken conclusies ten aanzien van de gemeten verschillen in de onderscheiden

\footnotetext{
${ }^{17}$ Hiertoe werd gezien de aard van de gegevens de Spearman rank-order test uitgevoerd.

${ }^{18}$ Deze significantie werd niét door de ter controle uitgevoerde Pearson-test bevestigd. Het getraceerde verband geeft in ieder geval aan dat wanneer extra tijd wordt besteed, dit niet per definitic leidt tot beterc beslissingen. Overigens waren de deelnemers hiervan niet overtuigd. Naarmate meer tijd werd genomen, steeg het vertrouwen in de gedane winstvoorspelling (correlatie-cosfficient 0,2846 bij een p-waarde van $4,85 \%$ ).

${ }^{19} \mathrm{Bij}$ deze laatste analyses is de Durbin-Watson test uitgevoerd om te zien of er sprake was van onderlinge gecorreleerdheid van de verschillen tussen winstvoorspelling en genormeerde voorspelling. In het genoemde geval bedroeg de Durbin-Watson coefficiënt 1,91 zodat hiervoor geen gegrond vermoeden bestaat. Ook in alle overige onderzochte gevallen schommelde de Durbin-Watson coefficiënt tussen 1.5 en 2.5 zodat van dit verschijnsel kan worden afgezien.
} 
groepen, niét ondermijnen. Dat wil zeggen: de correlaties zijn dermate laag dat deze de informatieve waarde van de uitgevoerde hypothese-tests niet aantasten ${ }^{20}$.

\subsection{Suggesties voor vervolgonderzoek}

In dit onderzoek is een aantal facetten van triple-entry en momentum accounting geanalyseerd. Het zal evenwel nog geruime tijd in beslag nemen en het nodige onderzoek vergen, alvorens kan worden gesproken van een nieuwe fase in de ontwikkeling van de management accounting.

Het experiment zoals dat is uitgevoerd is slechts een beperkte weergave van de mogelijkheden die bestaan bij het uittesten van de relevantie van een nieuw informatiesysteem. De gegevenskarakteristiek 'relevantie' is feitelijk twee-dimensionaal. Enerzijds gaat het om de vraag of gebruikers de verstrekte gegevens inderdaad in hun standpuntbepaling kunnen integreren (een aspect van bruikbaarheid of hanteerbaarheid) en anderzijds en vervolgens gaat het om de vraag of de gegevens ook daadwerkelijk tot kwalitatief betere beslissingen/oordelen leiden (een aspect van produktiviteit). Op basis van het uitgevoerde experiment is ten aanzien van dit tweede aspect van relevantie géén sluitend bewijs geleverd maar kan hoogstens van een (gegrond) 'vermoeden' worden gesproken. Dit aspect is slechts in een 'real-life' experiment te bewijzen waarbij voorspellingen niet met subjectieve normen (feitelijk ook zijnde voorspellingen) maar met echte uitkomsten worden vergeleken (zie ook de opmerking in voetnoot 8 bij dit hoofdstuk).

Omdat triple-entry en momentum accounting een aanpassing van het accountingmodel aan de basis betekenen, manifesteren zich de gevolgen van een dergelijk nieuw systeem op alle fronten van het financieel-administratieve proces. Met name het in dit verband noodzakelijke herontwerp van de administratieve organisatie en de interne controle is in deze dissertatie onderbelicht. (Hieronder valt mede het schrijven van nieuwe software.) Een case-studie zou heel wat licht op dergelijke aspecten kunnen werpen.

Slechts zeer beperkt is in dit onderzoek aandacht besteed aan de mogelijke gedragseffecten van triple-entry en momentum accounting. Een diepgaander onderzoek naar deze effecten zou een zeer welkome aanvulling betekenen, met name ook in het kader van de kosten-/baten-analyse van het nieuwe systeem. Ook is het in dit verband van belang te onderzoeken wat de invloed is van het nieuwe systeem nadat de gebruikers enige ervaring ermee hebben opgedaan (het leereffect). Met name in het kader van de prestatiebeoordeling kunnen dan belangrijke veranderingen optreden.

\footnotetext{
${ }^{20}$ In bovenstaand verband dient te worden opgemerkt dat dezc correlatietests niét als bewijs kunnen gelden van de validiteit van enig gedane bewering.
} 
Ook kan worden aangenomen dat het testen van de beslissingsrelevantie van triple-entry en momentum accounting in een groeps-setting andere resultaten oplevert dan de testing zoals die nu is uitgevoerd.

De betekenis van triple-entry en momentum accounting voor de externe berichtgeving is in deze dissertatie slechts zijdelings aan de orde gesteld. In het kader hiervan kan worden gedacht aan een wenselijkheids-onderzoek, een onderzoek naar de rol van de accountant(sverklaring) in dezen en een onderzoek naar mogelijke nieuwe richtlijnen.

Tot slot, ook aan de kant van de directe gebruikers kan triple-entry en momentum accounting de nodige veranderingen teweeg brengen. In dit verband valt te denken aan het ontwikkelen van nieuwe ratio's waarin de income momentum en de winstmutaties tot uitdrukking worden gebracht.

\subsection{Samenvatting}

In dit hoofdstuk zijn de resultaten besproken van een experiment waarin de beslissings-relevantie van triple-entry en momentum accounting is getest. Met betrekking tot de geanalyseerde kwaliteits-aspecten van beslissingen (nauwkeurigheid, verbruikte tijd en vertrouwen) kan op basis van de onderzoeksresultaten het volgende samenvattende overzicht worden opgemaakt. Hierbij is de spreiding rond de betreffende gemiddelde waarden als 'betrouwbaarheid' opgevat.

Tabel 9.1 Kwaliteits-aspecten van beslissingen en triple-entry en momentum accounting' (scores van triple-entry en momentum accounting ten opzichte van conventionele accounting).

\begin{tabular}{|l|l|}
\hline nauwkeurigheid & $\begin{array}{l}\text { significante } \\
\text { verbetering }\end{array}$ \\
\hline tijd & $\begin{array}{l}\text { significante } \\
\text { verbetering }\end{array}$ \\
\hline vertrouwen & $\begin{array}{l}\text { significante } \\
\text { verslechtering }\end{array}$ \\
\hline
\end{tabular}

De belangrijkste conclusie is dat de kwaliteit van de beslissingen zoals gemeten aan nauwkeurigheid en benodigde tijd, onder toepassing van triple-entry en momentum accounting aanzienlijk kan toenemen. Gebruikers zijn goed in staat de drie-dimensionale financiële gegevens in hun besluitvorming te integreren.

Het conventionele accountingmodel is in deze dissertatie geschetst als een 'onafgewerkte tors'. Triple-entry en momentum accounting geven in dit verband de 
mogelijke contouren aan van een verdere afwerking van deze tors. Deze bespiegeling geeft aanleiding tot een afsluiting in de algemeen-filosofische geest van Puxty en Pope (1989:25):

"Research is concerned with the extension of knowlegde; it may have financial benefits, but that is rarely its prime purpose, nor should it be the yardstick by which researchers are judged". 
then

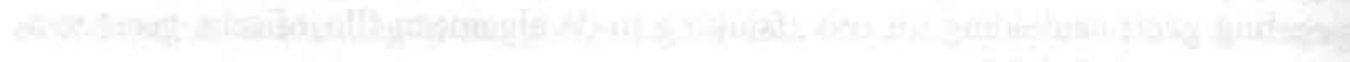

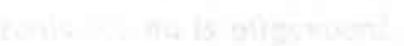

Wat

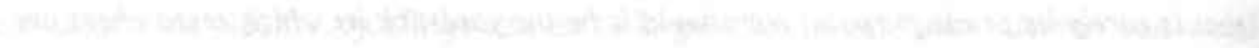




\section{Lijst van begrippen}

Actie

Action statement

Budgetrekening

Derde dimensie

Eerste dimensie

Financieel feit

Force (groeikracht)

Force accounting het effect van een winstkracht, gemeten in guldens

zie winst-mutatiestaat

grootboekrekening waarop mutaties in het te realiseren bedrag van een vermogensrekening worden geadministreerd

1) in temporal triple-entry accounting: het budget (toekomst);

2) in differential triple-entry (wealth) accounting: de oorzakelijke winstmutatie

de hoeveelheden van de samenstellende delen van het eigen vermogen

1.bij enkel boekhouden: elke bedocumenteerde gebeurtenis waardoor de samenstelling van het eigen vermogen verandert

2.bij dubbel boekhouden: elke bedocumenteerde gebeurtenis waardoor de samenstelling en/of omvang van het eigen vermogen verandert

3.bij temporal triple-entry accounting: elke bedocumenteerde gebeurtenis waardoor de (huidige) samenstelling en/of (huidige) omvang en/of te realiseren toename van de omvang van het eigen vermogen verandert

4.bij differential triple-entry accounting: elke bedocumenteerde gebeurtenis waardoor de (huidige) samenstelling en/of (huidige) omvang en/of winstcapaciteit van het eigen vermogen verandert

het effect van een winstkracht, uitgedrukt in guldens per periode per periode; een verandering in de winstsnelheid

een accountingsysteem waarin de financiële gevolgen van opgetreden winstkrachten worden geadministreerd in guldens per periode per periode 
Lijst van begrippen

Force statement

Impulse

Impulse statement

Income momentum

Momentum accounting

Momentum statement

Omvang van het eigen vermogen

Samenstelling van het eigen vermogen

Triple-entry (wealth) accounting (differential)

Triple-entry (wealth) accounting (temporal)

Tweede dimensie zie winstversnellings-staat

het effect van een winstkracht, gemeten in guldens per periode

zie winstsnelheids-mutatiestaat

zie winstsnelheid

accountingsysteem waarin de administratie van de income momentum centraal staat

zie winstsnelheids-staat

de totale geldswaarde van het nominaal geplaatst en volgestort aandelenvermogen, de reserves en de winst

opsomming (van de geldswaarde) van de (hoeveelheden] van de activa waarin het eigen vermogen is geünvesteerd alsmede van de (geldswaarde van de) (hoeveelheden\} verplichtingen welke zijn aangegaan

een accountingsysteem waarin drie dimensies van het eigen vermogen worden geadministreerd: samenstelling, omvang en oorzakelijke winstmutaties

een accountingsysteem waarin drie dimensies van het eigen vermogen worden geadministreerd: samenstelling, omvang en begroting

de (mutatie in de) omvang van het eigen vermogen zoals weergegeven door de posten van de resultatenrekening

Vermogensbestanddeel, grootboekrekening waarop mutaties in rekening van (een onderdeel van) de samenstelling van het eigen vermogen worden geadministreerd 
Vermogensrekening

Wealth

Wealth accounting

Winstcapaciteit

Winstkracht

Winst-mutatiestaat

Winstsnelheid

Winstsnelheidsmutatiestaat

Winstsnelheids-staat grootboekrekening waarop mutaties in (een onderdeel van) de omvang van het eigen vermogen worden geadministreerd

netto activa; de omvang van het eigen vermogen, gemeten als het saldo van bezittingen en schulden

accountingsysteem waarin de administratie van het eigen vermogen centraal staat

een op voldongen feiten gebaseerde uitdrukking van het realiseerbare bedrijfs-resultaat, gemeten in guldens, in guldens per periode of in guldens per periode per periode

feiten of gebeurtenissen waardoor de winstcapaciteit van het eigen vermogen van de onderneming verandert

systematisch overzicht dat een verklaring geeft voor de periodieke ontwikkeling in de posten van de resultatenrekening

de per een bepaald moment gemeten, niét oorzakelijk gedefiniëerde winstcapaciteit van het eigen vermogen, uitgedrukt in guldens per periode

systematisch overzicht dat een verklaring geeft voor de periodieke ontwikkeling in de samenstelling van de winstsnelheid

systematisch overzicht waarop de samenstelling van de winstsnelheid van het eigen vermogen van enig moment wordt getoond, uitgedrukt in guldens per periode

Winstversnellings-staat systematisch overzicht waarop de samenstelling van de winstsnelheid van het eigen vermogen van enig moment wordt getoond, uitgedrukt in guldens per periode per periode 


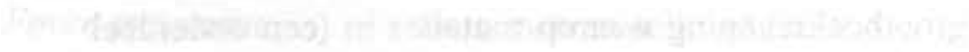

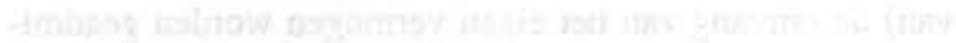

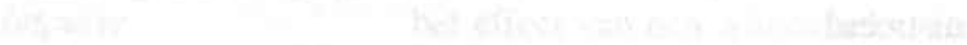

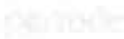

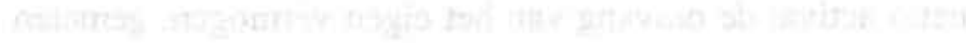

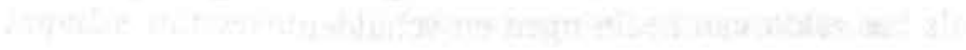

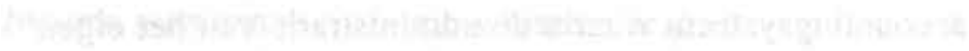




\section{Bijlage bij hoofdstuk 6 \\ 'Integrale tekst van de enquête'}

\section{Over uw opleiding.}

U kunt de letter van het van toepassing zijnde antwoord omcirkelen. Wilt u svp ook het jaar van afstuderen vermelden? In situatie $\underline{\mathbf{d}}$ graag een nadere toelichting.

a. Ik ben afgestudeerd in $19 \ldots$ als registeraccountant (RA) bij het NIvRA.

b. Ik ben afgestudeerd in $19 . .$. als registeraccountant (RA) via een postdoctorale accountantsopleiding.

c. Ik ben afgestudeerd in $19 \ldots$ als registercontroller (RC) via een postdoctorale controllersopleiding.

d. Anders:

\section{Over uw functie.}

Een extern accountant houdt zich gewoonlijk voornamelijk bezig met (jaarrekening-) controlewerkzaamheden, dat wil zeggen, controle van afgelegde verantwoording. Een intern accountant en een controller kunnen zich ook bezig houden met (interne) controlewerkzaamheden maar vaak beslaat hun werk meer dat van de advisering, dat wil zeggen, financieel-economische ondersteuning van beslissings- en uitvoeringsprocessen. Daarnaast bestaat de mogelijkheid dat $\mathrm{u}$ als eindverantwoordelijke van een bepaalde afdeling leiding geeft aan een aantal medewerkers.

Hoe ligt de verhouding binnen deze werkzaamheden in uw functie?

a. Qua tijdsbesteding is mijn huidige functie-inhoud:

controle-werkzaamheden advies-werkzaamheden (lijn-)management ...\% ...\% ...\% 
b. In hoeverre is de verdeling van werkzaamheden zoals bedoeld onder $\mathbf{a}$ in de afgelopen 3 jaar voor $\mathbf{u}$ gewijzigd? Drie jaar geleden was de verdeling van mijn werkzaamheden als volgt:

controle-werkzaamheden advies-werkzaamheden (lijn-)management
...\%
...\%
...\%

c. Ik houd mij bezig met andere werkzaamheden, te weten (eventueel een nadere verdeling aangeven)

\section{Over de duur van uw functie-verband.}

U kunt de letter van het van toepassing zijnde antwoord omcirkelen.

a. In mijn huidige functie ben ik minder dan 1 jaar werkzaam.

b. In mijn huidige functie ben ik langer dan 1 jaar maar minder dan 3 jaar werkzaam.

c. In mijn huidige functie ben ik meer dan 3 jaar werkzaam.

\section{Over uw werkkring.}

U kunt de letter van het van toepassing zijnde antwoord omcirkelen. In situatie Bb svp ook het betreffende land vermelden.

\section{A. Over de aard van uw bedrijf}

a. Ik ben werkzaam bij de overheid.

b. Ik ben werkzaam op een accountantskantoor.

c. Ik ben werkzaam in de non-profit sector.

d. Ik ben werkzaam in het (overige) bedrijfsleven.

\section{B. Over de oriëntatie van uw bedrijf}

a. Het bedrijf waar ik werk is hoofdzakelijk nationaal werkzaam, dat wil zeggen: $50 \%$ of meer van de omzet wordt in Nederland gerealiseerd.

b. Het bedrijf waar ik werk heeft een sterke internationale oriëntatie, dat wil zeggen: $50 \%$ of meer van de omzet wordt in het buitenland gerealiseerd. Het buitenland dat in dit verband het meest bepalend is: 
5. Over de positionering van uw werk.

Voor zover uw functie accountingwerkzaamheden betreffen, tot welk terrein behoren dan deze activiteiten?

FA= financial accounting (=externe berichtgeving; denk aan de verslaglegging naar aandeelhouders, bankiers en fiscus).

MA= management accounting (=interne berichtgeving; denk aan budgettering en kostprijsbepaling).

Onderstaande vijfpuntsschaal loopt van volledige oriëntatie op FA tot volledige oriëntatie op MA. Geeft u svp door het aankruisen van een hokje aan hoe uw accountingwerkzaamheden zijn verdeeld.

volledig FA

volledig $M A$

\begin{tabular}{|l|l|l|l|l|}
\hline 1 & 2 & 3 & 4 & 5 \\
\hline
\end{tabular}

Eventuele toelichting:

6.De functie van accounting in uw werk.

Voor zover u zelf accountingwerkzaamheden uitvoert, op welke functie zijn deze dan voornamelijk (meer dan $80 \%$ ) gericht? U kunt de letter van het van toepassing zijnde antwoord omcirkelen. In situatie $\mathbf{d}$ svp een nadere toelichting geven.

a. Het verstrekken van gegevens ten behoeve van de ondersteuning van te nemen beslissingen (planning).

b. Het verstrekken van gegevens ten behoeve van de beheersing van in uitvoer genomen beslissingen ('control').

c. Het verstrekken van gegevens ten behoeve van de verantwoording die over in het verleden genomen en uitgevoerde beslissingen dient te worden afgelegd.

d. Anders:

7.Het accountingsysteem in uw organisatie.

A. Het externe en interne berichtgevingssysteem (afgezien van het fiscale systeem) kunnen inhoudelijk aanzienlijk van elkaar verschillen (denk aan een afwijkend stelsel van winstbepaling, afwijkende waardering van vaste activa/voorraden, het doorberekenen van rente op eigen vermogen, en dergelijke). In welke mate verschillen het externe en interne berichtgevingssysteem in uw organisatie casu quo de organisatie(s) die u controleert? 
Onderstaande vijfpuntsschaal loopt van volledige overeenstemming tussen het externe en interne berichtgevingssysteem tot volstrekte afwijking tussen beide systemen. Geeft u svp door het aankruisen van een hokje aan in welke mate beide systemen van elkaar verschillen.

\begin{tabular}{|c|c|c|c|c|}
\hline \multicolumn{2}{|c|}{$\begin{array}{l}\text { volledige } \\
\text { overeenstemming }\end{array}$} & & \multicolumn{2}{|c|}{$\begin{array}{l}\text { volstrekte } \\
\text { afwijking }\end{array}$} \\
\hline 1 & 2 & 3 & 4 & 5 \\
\hline
\end{tabular}

\section{B. Indien voor u van toepassing (hokje $1 / 2$ bij vraag $7 \mathrm{~A}$ )}

Wat is naar uw mening de belangrijkste reden voor het gelijk houden van het externe en interne berichtgevingssysteem in uw organisatie casu quo de organisatie(s) die u controleert?

\section{Indien voor u van toepassing (hokje $3 / 4 / 5$ bij vraag $7 \mathrm{~A}$ )}

Op welke belangrijke accountingonderdelen wijken het externe en interne berichtgevingssysteem in uw organisatie casu quo in de organisatie(s) die u controleert, af?

$\mathrm{U}$ kunt de letter van het van toepassing zijnde antwoord omcirkelen. Onder 8 en 9 is ruimte gelaten voor in uw ogen specifieke verschillen in beide systemen.

1. afwijkende waardering van duurzame materiële activa (gebouwen/machines en dergelijke)

2. afwijkende waardering van duurzame immateriële activa (goodwill, research en dergelijke)

3. afwijkend stelsel van winstbepaling (absorption/direct costing, historische/actuele kosten)

4. afwijkende behandeling van voorzieningen (pensioenen, herstructurering en dergelijke)

5. afwijkende behandeling van lease-contracten

6. afwijkende behandeling van rente op eigen vermogen

7. afwijkende consolidatieprocedures (verwerking intercompanyprofits, waardering deelnemingen, en dergelijke)

8. afwijkende behandeling van

9. afwijkende behandeling van 


\section{Indien voor u van toepassing.}

Kunt u kort aangeven waarom het externe en interne berichtgevingssysteem afwijken op de door $\mathrm{u}$ onder $\mathrm{C}$ aangegeven onderdelen?

8.Uw ervaring met systeemaanpassingen.

In hoeverre hebben er, al dan niet onder uw leiding, de afgelopen drie jaar in de organisatie waar $\mathrm{u}$ thans werkt casu quo de organisatie(s) die u controleert belangrijke inhoudelijke aanpassingen in het interne berichtgevingssysteem plaatsgevonden? U kunt de letter van het van toepassing zijnde antwoord omcirkelen. In geval b graag een korte toelichting.

a. Er hebben geen belangrijke systeemaanpassingen plaatsgevonden.

b. Het interne berichtgevingssysteem is aangepast en wel als volgt (denk aan budgettering, kostprijssysteem, transferprijzen, stelsel van winstbepaling, waarderings-systeem):

9.Uw verwachting ten aanzien van toekomstige systeemaanpassingen.

Op welke aspecten verwacht $u$ in de organisatie waarin $u$ thans werkt casu quo de organisatie(s) die u thans controleert in de komende drie jaar belangrijke aanpassingen van het interne berichtgevingssysteem? U kunt de letter van het van toepassing zijnde antwoord omcirkelen. In geval b graag een korte toelichting.

a. Ik verwacht geen belangrijke aanpassingen.

b. Ik verwacht belangrijke aanpassingen en wel als volgt:

\section{Uw mening over financiële informatie.}

Ten aanzien van te verstrekken gegevens worden twee sleutel-kenmerken onderscheiden: relevantie ('relevance') en betrouwbaarheid ('reliability'). Welk aspect acht $u$ in uw werk het meest belangrijk? Voor beide aspecten is een vijfpuntsschaal uitgezet die loopt van bijzonder belangrijk tot volstrekt onbelangrijk. Geeft u svp door het aankruisen van een hokje aan in welke mate u het betreffende aspect voor uw eigen accountingwerkzaamheden belangrijk acht.

\section{a. Relevantie}

$\begin{aligned} & \text { bijzonder } \\
& \text { belangrijk }\end{aligned}$
\begin{tabular}{|c|c|c|c|c|}
\hline 1 & 2 & 3 & 4 & \multicolumn{1}{c}{$\begin{array}{c}\text { volstrekt } \\
\text { gnbelangrijk }\end{array}$} \\
\hline
\end{tabular}




\section{b. Betrouwbaarheid}

bijzonder

volstrekt

belangrijk

onbelangrijk

\begin{tabular}{|l|l|l|l|l|}
\hline 1 & 2 & 3 & 4 & 5 \\
\hline
\end{tabular}

Eventuele toelichting:

11.Nogmaals uw mening over financiële informatie.

Hierna zijn een 7-tal informatie-karakteristieken onderscheiden. Hoe zoudt $\mathrm{u}$, in het licht van $u w$ huidige accounting-werkzaamheden, de belangrijkheid van elk aspect inschalen? Voor de beantwoording is voor elk kenmerk een vijfpuntsschaal uitgezet die loopt van zeer belangrijk tot volstrekt onbelangrijk. Geeft u svp door het aankruisen van een hokje aan hoe belangrijk u elk aspect acht. Onder $h$, i en j kunt $\mathrm{u}$ eventuele door u belangrijk geachte (hier niet vermelde) aspecten toevoegen.

$\begin{aligned} & \text { bijzonder } \\
& \text { belangrijk }\end{aligned}$
\begin{tabular}{|c|c|c|c|c|}
\hline 1 & 2 & 3 & 4 & $\begin{array}{c}\text { volstrekt } \\
\text { onbelangrijk }\end{array}$ \\
\hline
\end{tabular}

a.predictive value

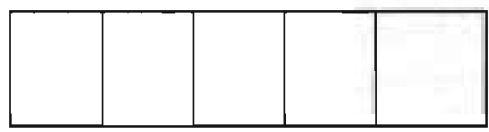

(waarde tbv voorspellingen)

b.feed-back value

(waarde tbv beheersing)

c.timeliness

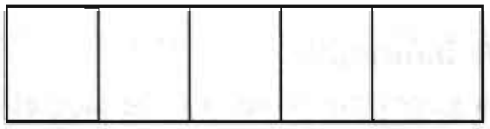

(tijdigheid)

d.neutrality

(onpartijdigheid)



f.comparability/ consistency

(vergelijkbaarheid/consistentie) 


\section{f.verifiability}

(controleerbaarheid)

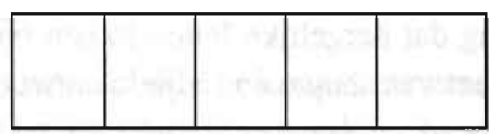

g.representational faithfulness (representativiteit/externe validiteit)

h.eventuele aanvulling

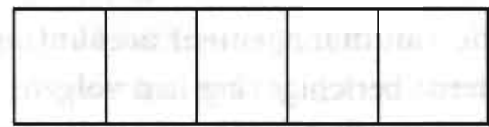

i.eventuele aanvulling

j.eventuele aanvulling
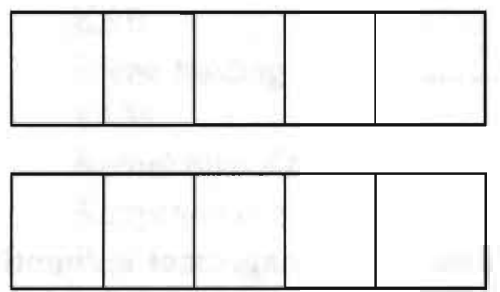

12.Uw mening over financiële feiten ('accounting events').

In een onderneming komt het management met het personeel voor de komende twee jaar een loonstijging van $4 \%$ per jaar overeen. U heeft berekend dat met deze beslissing de loonkosten in totaal met $f 120$ tot $f 125 \mathrm{mln}$ zullen stijgen.

A. Worden in uw organisatie casu quo de organisatie(s) die u controleert de gevolgen van deze overeenkomst direct (dus afgezien van de hogere loonbetalingen die in de tijd zullen plaatsvinden) in de boekhouding dan wel anderszins in de bedrijfsadministratie verwerkt? U kunt de letter van het van toepassing zijnde antwoord omcirkelen. Graag een nadere toelichting bij uw antwoord.

a. Neen, omdat

b.1 Ja, omdat

b.2 Zo ja, hoe vindt deze verwerking plaats? 
B. Bent $\mathbf{u}$ algemeen van mening dat dergelijke feiten in een boekhouding verwerkt dienen worden? U kunt de letter van het van toepassing zijnde antwoord omcirkelen. Graag een nadere toelichting bij uw antwoord.

1. Ja, omdat

2. Neen, omdat

$\underline{13}$.Uw mening over de evolutie van management accounting.

De kwaliteit van de huidige interne berichtgeving laat volgens sommigen nogal te wensen over. Bent u het met deze stelling eens? Graag een korte toelichting.

a. Neen, want

b. Ja, omdat

14.Uw mening over de toekomst van management accounting.

Hoe zou naar uw mening de kwaliteit van het interne berichtgevingssysteem in uw organisatie casu quo de organisatie(s) die u controleert, kunnen worden verbeterd? 


\section{Bijlage bij hoofdstuk 7}

'Lijst van bedrijven waarvan de toekomstverwachtingen (zoals opgenomen in het jaarverslag) zijn geanalyseerd'

\begin{tabular}{|c|c|c|}
\hline ACF holding & Hagemeyer & van der Moolen \\
\hline Ahold & HBG & VNU \\
\hline Ahrend & Heineken & Volker-Stevin \\
\hline AKZO & Hoogovens & Volmac \\
\hline Amev & Internatio-Müller & Vredestein \\
\hline Atag & $\mathrm{KBB}$ & West Invest Fortress \\
\hline Athlon groep & Klene holding & Wolters-Kluwer \\
\hline Bam groep & KLM & Wyers beheer \\
\hline Batenburg beheer & Koninklijke KNP-BT & \\
\hline Beers & Koppelpoort holding & \\
\hline Begemann groep & Krasnapolsky & \\
\hline Blijdenstein-Willink & Landré \& Glinderman & \\
\hline Boskalis Westminster & Macintosh & \\
\hline Braat Beheer & Multihouse & \\
\hline Breevast & Nedap & \\
\hline Cindu international & Nedlloyd & \\
\hline Content Beheer & Norit & \\
\hline Crown van Gelder & Nutricia & \\
\hline CSM & OCE van der Grinten & \\
\hline De Telegraaf & Pakhoed & \\
\hline De Boer winkel & Philips & \\
\hline Draka & Pirelli & \\
\hline DSM & Randstand & \\
\hline Elsevier & Schuitema & \\
\hline Eriks & Springstoffenfabrieken & \\
\hline Flexovit international & Stork & \\
\hline Fokker & Tulip & \\
\hline Frans Maas & Ubbink & \\
\hline Gamma & Unilever & \\
\hline Getronics & Union & \\
\hline Geveke & van Ommeren & \\
\hline Grolsch & van de Giessen-de Noord & \\
\hline GTI-holding & van Dorp groep & \\
\hline
\end{tabular}




\section{Bijlage A bij hoofdstuk 9 \\ 'Case gebaseerd op het conventionele accountingsysteem' (groep D)}

\section{Leasing Maatschappij NV}

\section{Achtergrondinformatie ten aanzien van CLM-NV}

Computer Leasing Maatschappij is een rechtspersoonlijkheid bezittende vennootschap die als bedrijfsactiviteit heeft het verhuren van computers met bijbehorende aanverwante apparatuur. De onderneming is opgericht per 1-1-1991 en is gevestigd te Utopia (een klein subtropisch eiland in het midden van de Stille Zuidzee). De geldeenheid welke wordt gehanteerd in Utopia, is de 'UCU' (Utopian Currency Unit). Deze geldeenheid wordt weergegeven met de ISO-code Ũ. Mede door het stringente monetair beleid van de Utopese regering, is de inflatie steeds nihil. Utopia kent bovendien geen belastingen.

CLM-NV is ontstaan uit een bedrijfsfusie met een tweetal, in moeilijkheden verkerende, verhuurvennootschappen. Dit waren TMG en SEG. Bij deze fusie werden, voorzover als mogelijk, de gezonde delen van de twee vennootschappen ondergebracht bij CLM-NV. Bij CLM-NV zijn 38 werknemers in dienst. Het bestuur wordt gevormd door een drietal directeuren, zijnde de directeur Technische Zaken \& Onderhoud, de directeur Commerciële Zaken en tenslotte de directeur Financieel-Economische Zaken.

Het verhuur van de computers cum annexis vindt plaats in de vorm van operational lease op basis van jaarcontracten. Er zijn geen boeteclausules opgenomen in deze jaarcontracten. Dit impliceert dat er per het einde van elk (contract)jaar vrije opzegging kan plaatsvinden, zonder enige directe financiële consequenties. Bij de oprichting van CLMNV zijn à pari aandelen geplaatst en volgestort voor een bedrag van U 300.000 .000 . In verband met het overgenomen personeel is aan goodwill Ũ 50.000 .000 betaald. Behalve het personeel heeft CLM van TMG en SEG de uitstaande vorderingen tegen het nominale bedrag van Ũ 180.000 .000 overgenomen.

Er volgt nu het financieel verslag (in casu de jaarrekening) van CLM-NV over het jaar 1992. Dit verslag bestaat uit de volgende componenten:

- de balans per 31-12-1992

- de resultatenrekening over 1992

- een toelichting op bovenstaande overzichten, alsmede vergelijkende cijfers over 1991. 
Aan de hand van deze gegevens worden u vervolgens enkele vragen voorgelegd. Uw antwoorden zullen worden gebruikt in het kader van een analyse van de kwaliteit van verstrekte gegevens. De eerste vraag is op basis van de beschikbare gegevens een voorspelling te doen voor de winst van CLM. Het is in dit verband tevens van belang dat u aangeeft hoe $u$ tot uw voorspelling bent gekomen. Voor dit 'protocol' en voor de beantwoording van de overige vragen is een afzonderlijke set beschikbaar.

Financieel Verslag Computer Leasing Maatschappij NV 1992

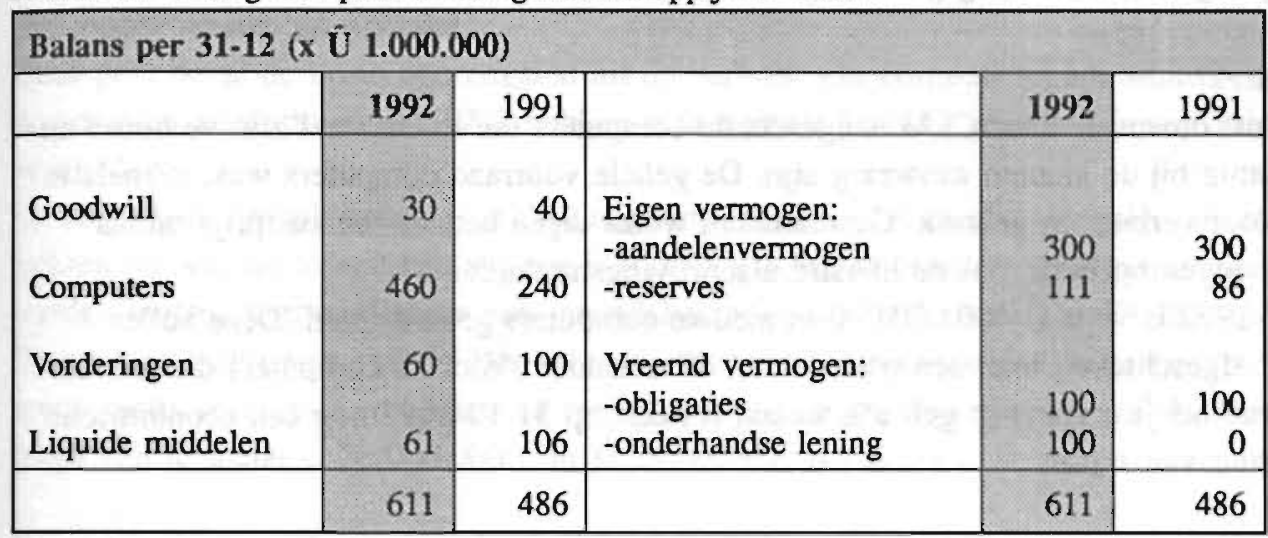

\begin{tabular}{|l|r|r|}
\hline Resultatenrekening over het jaar: $(\times \overline{\mathbf{U}} \mathbf{1 . 0 0 0 . 0 0 0})$ & 1992 & 1991 \\
\hline & 486,5 & 360 \\
\hline Netto-opbrengsten uit verhuur & 169,5 & 98 \\
Onderhoudskosten & 180 & 120 \\
Afschrijvingskosten computers & 137 & 142 \\
\hline Bruto-verhuurresultaat & 16 & 10 \\
Rentelasten & 10 & 10 \\
\hline Afschrijvingskosten goodwill & 111 & 122 \\
\hline Netto-winst uit verhuur & 26 & 0 \\
\hline Incidenteel verlies & 85 & 122 \\
\hline Netto-winst & & \\
\hline & 60 & 36 \\
Uitgekeerd dividend & 25 & 86 \\
\hline Toevoeging aan reserves & 85 & 122 \\
\hline Verdeelde netto-winst & & \\
\hline
\end{tabular}




\section{Toelichting}

\section{Balans}

\section{Goodwill}

Deze post betreft de betaalde goodwill op het bij de fusie van de vennootschappen TMG en SEG overgenomen personeel. Op het betaalde bedrag (Ũ 50.000.000) zijn de jaarlijkse afschrijvingen in mindering gebracht.

\section{Computers}

Deze post omvat de door CLM aangeschafte computers die momenteel zijn verhuurd en als zodanig bij de klanten aanwezig zijn. De gehele voorraad computers was, evenals in 1991, voor verhuur in gebruik. Gewaardeerd wordt tegen historische kostprijs minus afschrijvingen op basis van de lineaire afschrijvingsmethode.

Op 1-7-1992 is voor Ũ 400.000 .000 in nieuwe computers geïnvesteerd. Deze zullen worden afgeschreven over een periode van 40 maanden. Voor de computers die aan het begin van het jaar reeds in gebruik waren, resteert op 31-12-1992 nog een economische levensduur van 1 jaar.

\section{Vorderingen}

Deze post bevat de kortlopende vorderingen. Deze zijn gewaardeerd tegen nominale waarde. Eventueel oninbare vorderingen worden verrekend met de (bruto)opbrengsten uit verhuur van computers cum annexis.

\section{Liquide middelen}

Deze post omvat de kasmiddelen en de direct opeisbare tegoeden bij de bank.

\section{Eigen Vermogen}

Het aandelenvermogen bevat de nominale waarde van de volgestorte en opgevraagde aandelen. Er heeft in 1992 geen uitbreiding van het aandelenvermogen plaatsgevonden. De reserves zijn in 1992 slechts gewijzigd door dotatie van de niet-uitgekeerde winst over 1992. Met de aandeelhouders is overeengekomen dat met ingang van 1992 de jaarlijkse dividenduitkering (het dividendpercentage) zal worden verhoogd van $12 \%$ naar $20 \%$.

\section{Vreemd Vermogen}

Het vreemd vermogen bestaat uitsluitend uit leningen op lange termijn. Op de obligatielening heeft geen aflossing plaatsgevonden. Het betreft een ineens aflosbare obligatielening met ingangsdatum 1-1-1991, tegen 10\% rente per jaar, met een looptijd van 3 jaar. De rente dient jaarlijks te worden betaald, steeds per het einde van ieder jaar. 
In verband met de uitbreidingsinvestering in computers is per 1-7-1992 een ineens aflosbare onderhandse lening van Ũ 100.000 .000 afgesloten met een looptijd van 3 jaar. Er is een rentevergoeding overeengekomen van $12 \%$ per jaar. De rente dient halfjaarlijks te worden betaald, steeds per het einde van ieder halfjaar.

\section{Resultatenrekening}

\section{Netto-opbrengsten uit verhuur}

Deze post bevat de bruto-opbrengsten uit de verhuur van computers cum annexis, minus de oninbare vorderingen. In 1992 hebben zich evenals in 1991 geen oninbare vorderingen voorgedaan.

De stijging in de opbrengsten uit de computerverhuur is ontstaan als gevolg van de uitbreiding van de leasecapaciteit per 1-7-1992. De per deze datum ontvangen computers werden meteen verhuurd tegen een maandelijkse leasetermijn van Ũ 28.000 .000 in totaal. Door in gebruik name van de nieuwe computers bleek het noodzakelijk de leasetarieven op de reeds verhuurde computers te verlagen. Deze tarieven werden per 1-7-1992 verlaagd van in totaal Ũ 30.000 .000 naar Ũ 24.000 .000 per maand.

De concurrentie in de leasemarkt heeft zich in 1992 verhevigd. Ten gevolge hiervan is de omzet over 1992 zo'n Ũ 5.500 .000 achtergebleven bij de voor 1992 genormeerde omzet ad $\tilde{U}$ 492.000.000. Het bestuur gaat er van uit dat dit effect structureel is.

\section{Onderhoudskosten}

Deze post bevat alle kosten die kunnen worden toegerekend aan de onderhoudsactiviteiten van de verhuurde computers cum annexis.

Als gevolg van een groot aantal klachten van gebruikers heeft het bestuur besloten tot een permanente intensivering van de onderhoudsactiviteiten per 1-1-1992. Dit besluit alsmede het onderhoud aan de uitbreiding van het computernetwerk leidde tot een structurele stijging van de kosten voor onderhoud van Ũ 72.000 .000 ten opzichte van 1991. Alle kosten verbonden aan de onderhoudsactiviteiten zijn regelmatig over het jaar verspreid. De kostenreductie die met het achterblijven van de verhuuromzet wegens concurrentie gepaard ging, bedroeg Ũ 500.000 . Het bestuur gaat er van uit dat ook dit effect structureel is.

\section{Afschrijvingskosten computers}

De afschrijving op de verhuurde computers vindt plaats volgens de lineaire methode, uitgaande van de historische kostprijs en de geschatte economische gebruiksduur. Als gevolg van de snelle ontwikkelingen in de computerbranche wordt de restwaarde steeds op nihil gesteld. 


\section{Rentelasten}

Rentelasten worden uitsluitend betaald over langlopende leningen. De rentevergoeding op de obligatielening is $10 \%$ op jaarbasis. De rentevergoeding op de onderhandse lening bedraagt $12 \%$ op jaarbasis.

\section{Afschrijving op goodwill}

De afschrijving op de goodwill vindt plaats volgens de lineaire methode, uitgaande van de historische kostprijs. Afgeschreven wordt over een periode van 5 jaar.

\section{Incidenteel verlies}

Het bestuur concludeerde begin 1992 dat om op lange termijn optimaal op de ontwikkelingen op de computerleasemarkt te kunnen inspelen en aldus een strategisch sterke positie te kunnen behouden, het absoluut noodzakelijk was dat de bestaande organisatie werd gewijzigd. Besloten werd de functionele organisatiestructuur te vervangen door een meer gedecentraliseerde divisiestructuur. De reorganisatie werd aldus in 1992 geheel doorgevoerd. De kosten verbonden aan deze reorganisatie bedroegen Ũ 26.000.000.

\section{Algemeen}

In december 1992 werd met de vakbonden en werknemers overeengekomen de loonontwikkelingen in de branche te volgen. Als gevolg hiervan vindt met ingang van 1-11993 een loonstijging van $10 \%$ plaats voor het computeronderhoudspersoneel. Dit leidt tot een stijging van de jaarlijkse loonkosten van Ũ 120.000.000 naar Ũ 132.000.000. Deze loonkosten maken deel uit van de totale onderhoudskosten.

Voor 1993 wordt verwacht dat, als gevolg van groot onderhoud gemiddeld slechts $90 \%$ van de computerverhuur-capaciteit in gebruik zal zijn. Voor het bedoelde groot onderhoud is nog geen voorziening getroffen. Het management gaat er van uit dat, als gevolg van dit groot onderhoud, de opbrengst uit verhuur eenmalig zal dalen met Ũ 62.400 .000 en dat er incidenteel extra onderhoudskosten zullen worden gemaakt voor een bedrag van $\tilde{U}$ 27.750.000. 


\section{Bijlage B bij hoofdstuk 9 \\ 'Case gebaseerd op het drie-dimensionale accountingsysteem' (groep T)}

(De achtergrondinformatie alsmede de balans (met toelichting) en resultatenrekening (afgezien van de toelichting) welke aan groep $\mathrm{T}$ werden verstrekt, waren volledig gelijk aan datgene wat hieromtrent aan groep $D$ beschikbaar werd gesteld. Vandaar dat deze hier niét nogmaals zijn opgenomen.)

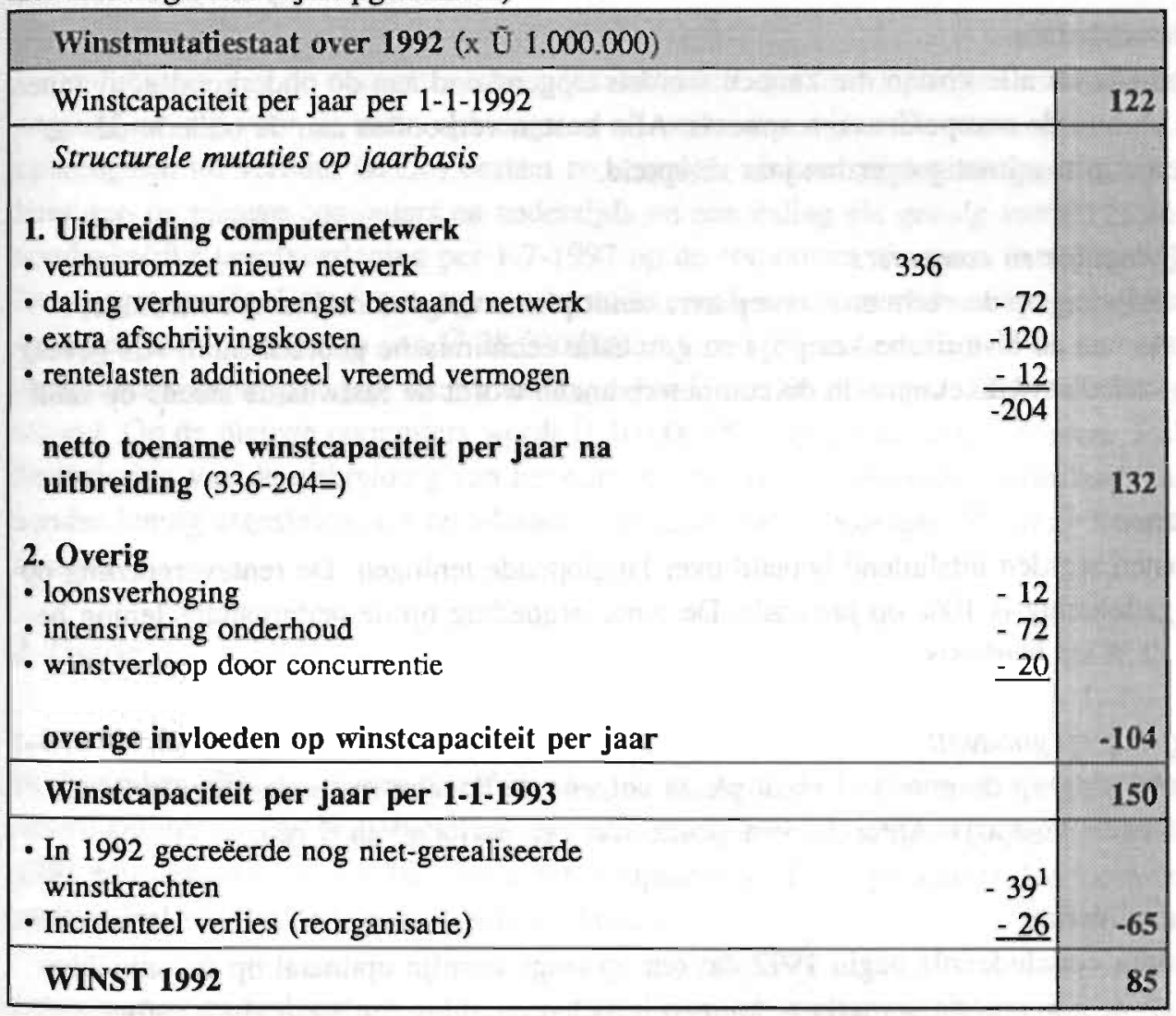

\footnotetext{
${ }^{1}$ het betreft hier:

huuropbrengsten $(6 / 12) \times(336-72)=\quad-132$

afschrijvingen $(6 / 12) \times 120=60$

rentelasten $(6 / 12) \times 12=6$

loonkosten/onderhoud (12/12) × $12=\quad 12$

invloed concurrentie $(9 / 12) \times(22-2)^{*}=\underset{\text { total }}{\frac{15}{39}}$
}

zie toelichting bij tabel 8.1 


\section{Resultatenrekening (toelichting)}

\section{Netto-opbrengsten uit verhuur}

Deze post bevat de bruto-opbrengsten uit de verhuur van computers cum annexis, minus de oninbare vorderingen. In 1992 hebben zich evenals in 1991 geen oninbare vorderingen voorgedaan. De stijging in de opbrengsten uit de computerverhuur is ontstaan als gevolg van de uitbreiding van de leasecapaciteit per 1-7-1992. Door in gebruik name van de nieuwe computers bleek het noodzakelijk de leasetarieven op de reeds verhuurde computers te verlagen.

\section{Onderhoudskosten}

Deze post bevat alle kosten die kunnen worden toegerekend aan de onderhoudsactiviteiten van de verhuurde computers cum annexis. Alle kosten verbonden aan de onderhouds-activiteiten zijn regelmatig over het jaar verspreid.

\section{Afschrijvingskosten computers}

De afschrijving op de verhuurde computers vindt plaats volgens de lineaire methode, uitgaande van de historische kostprijs en geschatte economische gebruiksduur. Als gevolg van de snelle ontwikkelingen in de computerbranche wordt de restwaarde steeds op nihil gesteld.

\section{Rentelasten}

Rentelasten worden uitsluitend betaald over langlopende leningen. De rentevergoeding op de obligatielening is $10 \%$ op jaarbasis. De rentevergoeding op de onderhandse lening bedraagt $12 \%$ op jaarbasis.

\section{Afschrijving op goodwill}

De afschrijving op de goodwill vindt plaats volgens de lineaire methode, uitgaande van de historische kostprijs. Afgeschreven wordt over een periode van 5 jaar.

\section{Incidenteel verlies}

Het bestuur concludeerde begin 1992 dat om op lange termijn optimaal op de ontwikkelingen op de computerleasemarkt te kunnen inspelen en aldus een strategisch sterke positie te kunnen behouden, het absoluut noodzakelijk was dat de bestaande organisatie werd gewijzigd. Besloten werd de functionele organisatiestructuur te vervangen door een meer gedecentraliseerde divisiestructuur. De reorganisatie werd aldus in 1992 geheel doorgevoerd. De kosten verbonden aan deze reorganisatie bedroegen Ũ 26.000.000. 


\section{Winst-mutatiestaat (toelichting)}

De winst-mutatiestaat voor CLM-NV geeft een overzicht van de financiële feiten die zich in 1992 hebben voorgedaan waardoor de winstsnelheid van het eigen vermogen is beïnvloed. Hierbij is er van uitgegaan dat de winstsnelheid (winstcapaciteit) per 1 januari 1992 gelijk was aan de over 1991 gerealiseerde winst. Op de winst-mutatiestaat zijn gebeurtenissen verwerkt die hebben geleid tot een mutatie van de winst in 1992 ten opzichte van 1991.

\section{Uitbreiding computernetwerk}

De uitbreiding van de computer-leasecapaciteit heeft een direct positief en een indirect negatief gevolg voor de netto-opbrengsten uit verhuur per jaar. De toename van de nettoopbrengsten uit verhuur (saldo) bestaat zo enerzijds uit een stijging als gevolg van de verhuur van de nieuwe computers en anderzijds uit een daling als gevolg van de hierdoor noodzakelijke tariefsverlaging per 1-7-1992 op de computers die reeds in verhuur waren. De per genoemde datum ontvangen computers werden meteen verhuurd tegen een maandelijkse leasetermijn van Ũ 28.000 .000 in totaal. De tarieven op de reeds verhuurde computers werden per deze datum verlaagd van Ũ 30.000 .000 naar Ũ 24.000 .000 per maand. Op de nieuwe computers wordt $\tilde{\mathrm{U}} 10.000 .000$ per maand afgeschreven. Ter financiering van de uitbreiding van het computernetwerk is een ineens aflosbare onderhandse lening afgesloten. De rentelasten over deze lening bedragen Ũ 1.000 .000 per maand.

\section{Overig}

\section{Loonsverhoging}

In december 1992 werd met de vakbonden en werknemers overeengekomen de loonontwikkelingen in de branche te volgen. Als gevolg hiervan volgt met ingang van 1-11993 een loonstijging van 10\% voor het computeronderhoudspersonecl. De loonkosten maken deel uit van de totale onderhoudskosten.

\section{Intensivering onderhoud}

Als gevolg van de toename van het aantal klachten in 1991 heeft het bestuur besloten tot een permanente intensivering van de onderhoudsactiviteiten per 1-1-1992. Dit leidde tot een stijging van de kosten voor onderhoud van U 72.000.000 ten opzichte van 1991.

\section{Winstverloop door concurrentie}

Begin oktober is een nieuwe concurrent op de markt gekomen ten gevolge waarvan de omzet in het laatste kwartaal $1992 \tilde{U} 5.500 .000$ is achtergebleven bij de voor dat kwartaal 
normale omzet. Het bestuur gaat er van uit dat dit omzet-effect blijvend van aard zal zija. De kostenreductie in het laatste kwartaal in 1992 ten gevolge van de verminderde omzet door het op de markt komen van de eerder genoemde nieuwe concurrent bedroeg $\tilde{U}$ 500.000. Ook dit kosten-effect acht het bestuur blijvend van aard.

\section{Incidenteel verlies (reorganisatie)}

Zoals reeds vermeld bij de toelichting op de resultatenrekening (onder 'Incidenteel verlies'), werden er in 1992 eenmalige kosten gemaakt ten behoeve van een reorganisatie.

\section{Algemeen}

Voor 1993 wordt verwacht dat, als gevolg van groot onderhoud gemiddeld slechts $90 \%$ van de computerverhuur-capaciteit in gebruik zal zijn. Voor het bedoelde groot onderhou is nog geen voorziening getroffen. Het management gaat er van uit dat, als gevolg van dit groot onderhoud, de opbrengst uit verhuur eenmalig zal dalen met Ũ 62.400 .000 en dat $\mathrm{er}$ incidenteel extra onderhoudskosten zullen worden gemaakt voor een bedrag van $\tilde{U}$ 27.750.000. 


\section{Bijlage C bij hoofdstuk 9 'Vooraf aan groep T verstrekte informatie'}

De winst-mutatiestaat (10 minuten leestijd)

\section{Algemene informatie over opmaak en gebruik}

Wanneer een auto in de periode A-B een afstand aflegt die gelijk is aan de afstand tussen plaats $X$ en plaats $Y$, gebeurt dit met een bepaalde snelheid. Nu kan men de gemiddelde snelheid uitrekenen die is gereden in de periode A-B, stel $90 \mathrm{~km}$ per uur (= afgelegde afstand gedeeld door het aantal uren). Dit gegeven betekent evenwel niet dat de snelheid op alle momenten in de periode A-B ook $90 \mathrm{~km}$ per uur is geweest. Een en ander is ondermeer een kwestie van acceleratie (het vermogen om te versnellen). De snelheid van de auto vlak voor het bereiken van plaats Y kan bijvoorbeeld $120 \mathrm{~km}$ per uur zijn. Dit aanvullende gegeven is onder andere van belang wanneer een uitspraak moet worden gedaan over de tijd die de auto nodig zal hebben wanneer wordt doorgereden van plaats Y naar plaats $\mathrm{Z}$.

Een bedrijf kan in een bepaald opzicht worden beschouwd als een auto: op weg van de ene (vermogens)positie naar een andere. De winst die over een bepaalde verslagperiode is gerealiseerd (meestal een jaar), kan worden vergeleken met de gemiddelde over dat jair gerealiseerde winstsnelheid of winstkracht van het in het bedrijf (gemiddeld) geinvesteerde eigen vermogen. In een traditioneel dubbel boekhoudmodel wordt slechts over deze gemiddelde snelheid gerapporteerd en wordt deze in de tijd constant geacht. In een driedimensionaal accountingmodel (Engels: triple-entry accounting) kan ook de ontwikkeling van de winstsnelheid (toename/afname) worden geadministreerd. Derhalve kan met versnellingen/vertragingen expliciet rekening worden gehouden. Dit betekent dat over het verloop van de winstsnelheid vanaf het begin van het verslagjaar tot en met het eind van het verslagjaar kan worden gerapporteerd. Het overzicht waarop de ontwikkeling van de winstsnelheid gedurende een bepaalde periode wordt getoond, wordt winst-

mutatiestaat genoemd. Op een winst-mutatiestaat staat niet het resultaat over een jaar (zoals op de resultatenrekening) maar is de ontwikkeling in het resultaat per jaar (=winstsnelheid) geschetst. De winstsnelheid wordt per een bepaald moment gemeten. De winst daarentegen, als zijnde de realisatie van een bepaalde (potentiële) winstsnelheid, heeft betrekking op een bepaalde periode. De winst-mutatiestaat geeft een sluitende afstemming tussen het resultaat van een bepaalde periode en de winstsnelheid zoals die per het einde van die periode bestaat en als zodanig geeft deze staat een systematische verklaring voor het verschil in winst over twee perioden. 
Wat betreft de winstsnelheid (winstcapaciteit) van het eigen vermogen zijn bijvoorbeeld rente- of loonbetalingen niét van belang. Deze kosten beïnvloeden wél het resultaat over een verslagperiode maar niét de winstsnelheid. Gewijzigde rentepercentages, nieuwe loon. afspraken en bijvoorbeeld het failliet gaan van een belangrijke klant beïnvloeden de winstsnelheid daarentegen wél en derhalve dienen de verwachte effecten van deze feiten te worden omgerekend en in het administratieve systeem te worden verwerkt.

Wanneer de winstsnelheid van een bedrijf op enig tijdstip bijvoorbeeld 100 per maand bedraagt, betekent dit dat in principe in elke volgende maand 100 kan worden verdiend. Hierbij dient te worden aangetekend dat om reden van objectiviteit en controleerbaarheid in dit cijfer geen 'pure' verwachtingen zijn verwerkt. Triple-entry accounting betekent he ${ }_{t}$ administratief (systematisch en stelselmatig) verwerken van verwachte effecten van voldongen feiten. (Indien verwachte effecten van verwachte feiten worden geadministreerd, is sprake van een budget- of begrotingssysteem.) 
Bijlage D bij hoofdstuk 9
'Vragenlijst voor groep D'

Protocol voorspelling

1.

Indien u voor CLM-NV op basis van de verstrekte gegevens een voorspelling van het winstciffer over 1993 zou moeten doen, hoe zou deze voorspelling dan luiden? $\mathrm{U}$ wordt verzocht op het eerste blad van deze set aan te geven hoe u tot deze voorspelling bent gekomen.

Voorspelling winstcijfer: $\times \tilde{U} 1.000 .000$

2.

Hoeveel tijd heeft u nodig gehad om tot de onder 1 bedoelde voorspelling te komen? (zie de stopwatch!)

Tijdsduur voorspelling: ......min./.....sec.

3.

Indien u op een schaal van 0-100 procent de mate zou moeten aangeven van het vertrouwen dat $u$ heeft in $u w$ voorspelling, wat zou u dan aangeven?

Mate van vertrouwen in voorspelling: ..... procent

4.

Wanneer u de 'financial performance' van het management van CLM-NV over 1992 in een rapportcijfer (schaal 1-10) zou moeten uitdrukken, welk cijfer zou u dan geven?

Cijfer functioneren management: ..... (alleen hele cijfers)

5.

Waarop heeft $u$ het rapportcijfer onder 4 in hoofdzaak gebaseerd? Tenzij een andere beschrijving gewenst is (zie d) s.v.p. het van toepassing zijnde antwoord omcirkelen.

a. De winst over het jaar 1992 ten opzichte van de behaalde winst in 1991 . 
b. De in 1992 gecreëerde structurele winstmogelijkheden voor de toekomst.

c. De door u voorspelde winst voor 1993.

d. Anders, nl.

6.

Stel dat u de directeur Financieel-Economische Zaken bent van CLM-NV en dat u eind 1992 door uw collega-bestuursleden wordt verzocht het accountingsysteem aan te wenden ten einde via 'creatief boekhouden' de financiële performance van de onderneming te verbeteren. Hierbij wordt gedacht aan het activeren van de reorganisatiekosten om deze vervolgens lineair in vijf jaar af te schrijven. Voor de controlerend accountant zou deze alternatieve verwerking geen probleem zijn bij het verstrekken van een goedkeurende verklaring.

Acht $\mathrm{u}$ het voorstel van de overige bestuursleden effectief?

Uw stellingname motiveren s.v.p.

a. Ja, want

b. Nee, want

7.

Hoeveel jaar bent $u$ als controller/management accountant in uw huidige functie werkzaam?

Aantal jaren in huidige functie: ..... jaar

8.

Hoe zou u uw huidige functie willen karakteriseren?

S.v.p. aankruisen wat van toepassing is tenzij een andere beschrijving gewenst is.

... Administratief/Accounting

... Treasury

... Financiering

... Management

Anders, te weten: 
9.

Indien u voorafgaand aan dit experiment uw bereidheid om aan dit onderzoek mee te doen in een rapportcijfer (schaal 1-10) zou moeten uitdrukken, welk cijfer zou u dan geven?

Bereidheid deelname experiment: .... (alleen hele cijfers)

10.

Indien $\mathrm{u}$ het realiteitsgehalte van de $u$ voorgelegde case in een rapportcijfer zou moeten uitdrukken, welk cijfer zou u dan geven? Desgewenst kunt u hierbij een toelichting geven.

Realiteitsgehalte case: .... (alleen hele cijfers)

Eventuele toelichting: 


\section{Bijlage E bij hoofdstuk 9 \\ 'Vragenlijst voor groep T'}

(De vragenlijst voor groep $\mathrm{T}$ was op twee vragen na gelijk aan de vragenlijst welke groep $\mathrm{D}$ is voorgelegd (zie bijlage $\mathrm{D}$ ). Om deze reden zijn hierna uitsluitend deze twee toegevoegde vragen opgenomen.)

1.

Hoeveel van de onder 2 aangegeven tijd heeft $\mathrm{u}$ ongeveer nodig gehad om u vertrouwd te maken met het drie-dimensionale accountingsysteem en de hieraan gekoppelde winstmutatiestaat?

Hierbij niet meerekenen de 10 minuten welke u heeft gekregen voor het bestuderen van de winst-mutatiestaat in het algemeen.

Tijd gebruikt voor

winst-mutatiestaat: $\min$.

2.

Was u voorafgaand aan dit experiment bekend met de inhoud en betekenis van een driedimensionaal accountingsysteem en de hieraan gekoppelde winst-mutatiestaat? S.v.p. aankruisen wat van toepassing is.

....in het geheel niet ....enigszins ....volledig bekend 


\section{Lijst van geraadpleegde literatuur}

Abdel-Khalik, R. en B.B. Ajinkya, Empirical Research in Accounting: A Methodological Viewpoint, American Accounting Association, 1979

American Institute of Certified Public Accountants, Objectives of Financial Statements:

Report of the Study Group on the Objectives of Financial Statements, 1973 Accounting Standards Board (ASB), Exposure Draft-Statement of Principles, The

Objective of Financial Statements and the Qualitative Characteristics of Financial Information, Accountancy, september 1991 Ackoff, R.L., Creating the Corporate Future, 1981 Ahituv, N. en S. Neumann, Principles of information systems for management, 1986 Alonso, M. en E.J. Finn, Fundamental University Physics, Mechanics and

Thermodynamics, 1980

American Accounting Association, A Statement of Basic Accounting Theory (ASOBAT), 1966

Amigioni, F., Planning Management Control Systems, Journal of Business Finance and Accounting, 1978, pag. 279-291

Anthony, R.N. en J.S. Reece, Accounting: Text and Cases, 1983

Anthony, R.N., Tell It Like It Was, A Conceptual Framework for Financial Accounting, 1983

Anthony, R.N, J. Dearden en N.M. Bedford, Management Control Systems, 1989 Anthony, R.N., We don't have the accounting concepts we need, artikel in de bundel:

Getting numbers you can trust, The new accounting, 1991

Armitage, H.M. en W.J. Skelton, Accounting Systems and the Limits to Quality

Management Decision Making, Business Quarterly, 1987

Amold, J., The future shape of financial reports, Accountancy, mei 1991

Ashby, W., An Introduction to Cybernetics, 1956

Ashton, R.H., Discussion of An Assessment of Laboratory Experiments in Accounting,

Journal of Accounting Research, vol. 20, 1982, pag. 102-107

Ashton, D, T. Hopper en R.W. Scapens, Issues in Management Accounting, 1991,

pag. 1-16

Asimov, I., De moderne natuurwetenschappen, 1966

Asman, M.F., S.S. Cowen en S.L. Mandell, Accounting Today, Principles and Applications, 1986 
Babad, Y.M. en B.V. Balachandran, Operational matrix accounting, Journal of Accounting Research, 1990, pag. 775-793

Bailey, J., Implementation of ABC systems by UK companies, Management Accounting, februari 1991

Ball, R. en P. Brown, An Empirical Evaluation of Accounting Income Numbers, Journal of Accounting Research, najaar 1968, pag. 159-178

Beaver, W.H., J.W. Kennelly en W.M. Voss, Predictive Ability as a Criterion for the Evaluation of Acounting Data, The Accounting Review, oktober 1968, pag. 675-683

Beaver, W.H. en J.S. Demski, The Nature of Income Measurement, The Accounting Review, januari 1979 , pag. $38-46$

Belkaoui, A., Accounting Theory, 1992

Bell, Ph.W., Accounting as a Discipline for Study and Practice: 1986, paper, 1986, pag. 1-64

Bemelmans, T.M.A., Bestuurlijke informatiesystemen en automatisering, 1987

Beresford, D.R., Financial reporting in the 1990's, Management Accounting, november 1990

Bergh, van den A., Continue interest - schijn en werkelijkheid, Maandblad voor Bedrijfsadministratie en -Organisatie, december 1991

Bergh, van den A. en M.S. Mulder, Verschillende golflengtes bij renteberekeningen, Maandblad voor Bedrijfsadministratie en -Organisatie, augustus 1992

Birnberg, J.G. en R. Nath, Implications of Behavioral Science for Managerial Accounting, Accounting Review, juli 1967, pag. 468-479

Bimberg, J.G. en R. Nath, Laboratory Experimentation in Accounting Research, Accounting Review, januari 1968, pag. 38-45

Birnberg, J.G., Managerial accounting: yet another retrospective, Advances in Management Accounting, volume 1, 1992, pag. 1-19

Blommaert, J.M.J. en A.M.M. Blommaert, Elementaire Bedrijfsadministratie, 1984

Blommaert, A.M.M. en J.H.R. van de Poel, Implementation of Strategy and Accounting Systems Design, working paper, 1987

Blommaert, J.M.J, S.F. Foster, B. Messing en A.M.M. Blommaert, Innovation in teaching Financial Accounting at the University of Limburg, Faculty of Economics, paper, 1988

Blommaert, A.M.M. en J.M.J. Blommaert, Drie-dimensionaal boekhouden deel I, Maandblad voor Bedrijfsadministratie en -Organisatie, maart 1990

Blommaert, A.M.M. en J.M.J. Blommaert, Drie-dimensionaal boekhouden deel II, Maandblad voor Bedrijfsadministratie en -Organisatie, april 1990-2

Blommaert, J.M.J., A.M.M. Blommaert en A. Beek, Bedrijfsadministratieve Analyses, een inleiding in het ontwerp en de toepassing van financiële informatiesystemen op hbo-wo niveau, 1989 
Blommaert, A.M.M., J.M.J. Blommaert en H.C. Wytzes, Bedrijfseconomische Analyses, een inleiding bedrijfseconomie op hbo-wo niveau, 1991-1, tweede druk

Blommaert, A.M.M., J.M.J. Blommaert en R.S. Hayes, Financial Decision Making, an introduction to managerial accounting, financial accounting and financial management, 1991-2

Blommaert, A.M.M. en J.M.J. Blommaert, Enkele recente ontwikkelingen in de bedrijfseconomie, Tijdschrift voor het economisch onderwijs, mei 1991-3

Blommaert, A.M.M., Management Accounting, Conceptual Framework and Triple-Entry Accounting, paper, EAA-congres Madrid, april 1991-4

Blommaert, A.M.M., P.J. Eimers en T.L.C.M. Groot, De betekenis van ABC voor de Nederlandse Bedrijfseconomie, Maandblad voor Bedrijfsadministratie en -Organisatie, mei 1992-1, pag. 115-122

Blommaert, A.M.M. en J.M.J. Blommaert, Bedrijfscalculatie, deel 1 en deel 2, 1992-2 Blommaert, A.M.M., Hoofdlijnen van de geschiedenis van (management) accounting, Tijdschrift voor Bedrijfsadministratie, december 1992-3

Blommaert, A.M.M. en J.J.M. Hintzen, Strategische positionering, management control en het transferprijzen-vraagstuk, Tijdschrift voor Bedrijfsadministratie, maart 1993-1

Blommaert, A.M.M., J.M.J. Blommaert en R.S. Hayes, Financieel Economisch Management, een inleiding in de bedrijfsadministratie, management accounting, financial accounting en financieel management, 1993-2

Blommaert, A.M.M., Gegevensperceptie en financiële functie, Maandblad voor Accountancy en Bedrijfseconomie, november 1993-3

Blommaert, J.M.J. en A.M.M. Blommaert, De wettelijke regels omtrent de jaarrekening van ondernemingen, Tijdschrift voor het economisch onderwijs, oktober 1993-4

Blommaert, A.M.M., J.M.J. Blommaert, J.L. Bouma, T.L.C.M. Groot en J.G. Kuijl, Bedriffseconomische Grondslagen, Inleiding in de Bedrijseconomie, 1994

Blommaert, A.M.M., J.M.J. Blommaert, Regaining management accounting relevance: The concept of income momentum, From Pacioli to Ijiri, paper, EAA-congres Venetie,, april 1994

Boom, van der A.H. en F. van der Grift, De frequentie bij interest- en discontoberekeningen: een vergeten grootheid? (deel $1 \mathrm{t} / \mathrm{m}$ 4), Maandblad voor Bedrijfsadministratie en -Organisatie, februari-mei 1991

Boom, van der A.H. en F. van der Grift, Vermogensvergoedingen en golflengte, Maandblad voor Bedrijfsadministratie en -Organisatie, april 1992

Boons, A.N.A.M, Ontwikkelingen in Management Accounting Systemen, Pacioli Journaal, januari 1990, pag. 6-10

Bolwijn, P.T., Continuïteit en vernieuwing van produktiebedrijven, inaugurele rede, Universiteit Twente, 1988

Bosman, A., Planning en administreren, in: Ontwikkelingen rond informatiesystemen, 1984, pag. $199-215$ 
Bosman, A. en H.G. Sol, Systemen voor Management Ondersteuning, in: Ontwikkelingen rond informatiesystemen, 1984, pag. 139-162

Boulding, K.E., General system theory - the skeleton of science, General System, I, 1956 Bouma, J.L., De kneedbaarheid van het financieel-administratieve beeld van een organisatie, in: Ontwikkelingen rond informatiesystemen, 1984, pag. 216-228

Bouma, J.L., Leerboek der Bedrijfseconomie, deel II, 1988

Bouma, J.L., Leerboek der Bedrijfseconomie, deel IA, 1984

Bouma, J.L., Ontwikkelingen in het Management Accounting-onderzoek, Maandblad voor Accountancy en Bedrijfseconomie, november 1990, pag. $478-490$

Bouma, J.L., Leerboek der Bedrijfseconomie, deel IIA, 1991

Bouma, J.L., Management Accounting in het kader van economische organisatie theorieën: deel $1 \mathrm{t} / \mathrm{m} \mathrm{4,} \mathrm{Maandblad} \mathrm{voor} \mathrm{Bedrijfsadministratie} \mathrm{en} \mathrm{-Organisatie,} \mathrm{mei-}$ september 1992-1

Bouma, J.L., Management Accounting na Limperg: De ontwikkeling in de theorie, Stichting Moret Fonds, Limperg-dag 1991, 1992-2

Brevoord, C., Informatiebeleid, 1971

Bricker, R.J., The Importance of History for Accounting Research, Abacus, 1991, vol. 27, no. 1, pag. 72-77

Brimson, J.A., How Advanced Manufacturing Technologies are reshaping Cost Management, Management Accounting, maart 1986, pag. 25-29

Brink, H.L., 's Lands wijs, 's lands eer, inaugurele rede, Rijksuniversiteit Limburg, 1989 Brink, H.L., ...en ook overigens in overeenstemming is met de wettelijke bepalingen inzake de jaarrekening, De Accountant, september 1991

Bromwich, M., Managerial Accounting Definition and Scope From a Managerial View, Management Accountant, september 1988, pag. 26.

Bromwich, M. en A. Bhimani, Management Accounting: Evolution not Revolution, Management Accounting, oktober 1989, pag. 5-6

Brownell, P., The Role of Accounting Information, Environment and Management

Control in Multi-National Organizations, Accounting and Finance, 1989, vol. 27, nr. 1, pag. 1-16

Bruns, W.J. en R.S. Kaplan, Accounting \& Management, Field Study Perspectives, 1987 Buijink, W.F.J., Empirical financial accounting research (dissertatie Rijksuniversteit Limburg), 1992 
Capra, F., De tao van fysica (The Tao of Physics), 1975

Capra, F., Het nieuwe denken (Uncommon Wisdom), 1988

Carmichael, B., Step aside double entry, Quad Accounting, Australian Accountant, september 1987

Chandler, A.D., Strategy and Structure, 1966

Chatfield, M., A History of Accounting Thought, 1977

Chenhall, R.H. en D. Morris, The Impact of Structure, Environment, and Interdependence on the Perceived Usefulness of Management Accounting Systems, The Accounting Review, 1986, vol. 61, nr. 1, pag. 16-35

Clark, J.M., Studies in the economics of overhead costs, 1947

Coase, The nature of the firm, Economica, 1937, vol. 4, pag. 386-405

Cohen-Scali, J., Une révolution presque silencieuse, De lapartie double aux système croisé, au système triadique, R.F.C. 217, november 1990

Collier, P.A., The impact of Information Technology on the Management Accountant, The Institute of Cost and Management Accountants, 1984, pag. 1-65

Conseil National de la Comptabilité, Normalisation Comptable et Gestion de

L'Entreprise, L'intégration par le Systeme Croisé, 1989

Cooper, R., Does Your Company Need a New Cost System?, Cost Management, voorjaar 1987, pag. 45-49

Cooper, R. en R.S. Kaplan, How Cost Accounting Systematically Distorts Product Costs, Accounting \& Management, april 1988, pag. 20-27

Cooper, W.W. en G. Kozmetsky, Accounting Research in Theory and Practice, from Pacioli to Ijiri, paper, 1992, 1-17

Cornick, M., W.D. Cooper en S.B. Wilson, How Do Companies Analyze Overhead?, Management Accounting, juli 1988, pag. 41-43

Coulthurst N. en J. Piper, The state of cost and management accounting, Management Accounting, april 1986, pag. 38-40

Cunningham, G.M., Management Control and Accounting Systems under a Competitive Strategy, Accounting, Auditing \& Accountability Journal, 1992, vol. 5, nr. 2, pag. 85101

Cushing, B.E., A Kuhnian Interpretation of the Historical Evolution of Accounting, The Accounting Historians Journal, 1985, pag. 1-41

Cushing, B.E. en M.B. Romney, Accounting Information Systems and Business Organizations, 1987

Cushing, B.E., On the Feasibility and the Consequences of a Database Approach to Corporate Financial Reporting, Journal of Information Systems, 1989 Cutcheon, J.J. en W.F. Scott, An Introduction to the Mathematics of Finance, 1989 
Dam, ten M., Bewustzijn en materie, 1985

Date, C.J., An Introduction to Database Systems, 1986

David, H., Accounting Information Systems, A control Emphasis, 1983

Dearden, J., Measuring Profit Center Managers, Harvard Business Review, 1987, pag. $84-88$

DeJong, D.V., R. Forsythe, Jae-Oh Kim en W.C. Uecker, A laboratory investigation of alternative transfer pricing mechanisms, Accounting, Organizations and Society, 1989, vol. 14, pag. 41-64

Demski, J.S., Uncertainty and Evaluation Based on Controllable Performance, Journal of Accounting Research, augustus 1976, pag. 230-245

Demski, J.S., Accounting Research: 1985, Contemporary Accounting Research, 1986, no. 1, pag. 69-75

Dermer, J., Cognitive Characteristics and the Perceived Importance of Information, The Accounting Review, juli 1973, pag. 511-519

Dermer, J., en R.G. Lucas, The illusion of managerial control, Accounting, Organizations and Society, 1986, vol. 11, no. 6, pag. 471-482

Dijk, M. van, Onderzoekmethoden en onderzoekdilemma's bij management accounting onderzoek, Maandblad voor Accountancy en Bedrijfseconomie, februari 1993

Dijk, M. van, 'Niet-rationele' accountingpraktijken in organisaties, Maandblad voor Accountancy en Bedrijfseconomie, november 1993, pag. 504-518

Dijksma, J., Het meten van de kwaliteit van (gegevens) in het externe financiële jaar rapport, Pacioli Journaal, september 1991, pag. 26-31

Douma, S. en H. Schreuder, Economic Approaches to Organizations, 1992

Drenth, J.J., Mutidimensionaal boekhouden, afstudeerscriptie, post-doctorale controllersopleiding, Rijksuniversiteit Limburg, 1992

Drury, C., Product Costing in the 1990's, Accountancy, Mei 1990

Dyckman, T.R., The effect of Alternative Accounting Techniques on Certain Management Decisions, Journal of Accounting Research, 1964, pag. 1-17

Dyckman, T.R., R.E. Hoskin en R.S. Swieringa, An Accounting Change and Information Processing Changes, Accounting, Organizations and Society, 1982, vol. 7, pag. 1-11

Eccles, R., The transfer pricing problem, 1985

Edstrom, O., Man-Computer Decision Making, 1973

Edwards, J.R., A history of Financial Accounting, 1987

Edwards, E.O. en Ph.W. Bell, Theory and Measurement of Business Income, 1961

Eijkelberg, J., Triple-entry accounting, een experimentele case-study, doctoraalscriptie, Rijksuniversiteit Limburg, 1992 
Eiler, R.G., W.K. Goletz en D. P. Keegan, Is your accounting up to date, Harvard Business Review, juli-augustus 1982, pag. 133-139

Einhom, H.J. en R. M. Hogarth, Behavioral Decision Theory: Processes of Judgment and Choice, Journal of Accounting Research, 1986, vol. 19, no. 1, pag. 1-40)

Eldridge, H.J., The Evolution of the Science of Book-Keeping, The Institute of Book-

Keepers' Journal, maart 1930, pag. 6-15

Elsevier NV, jaarverslag 1989

Emmanuel, C.R. en D.T. Otley, Accounting for Management Control, 1985

Epstein, M.J., The Origins of Double Entry Bookkeeping in America, paper,

1990, pag. 1-21

Etehridge, H.L. en R.S. Sriram, Chaos Theory: Implications for Accounting Research, AAA-paper, 1993

Euske, K.J., Management control: planning, control, meausurement, and evaluation, 1984 Ewalts, G., Van een kinematisch naar een kinetisch accounting-model: een onderzoek naar de administratie van winstkrachten, afstudeerscriptie, Rijksuniversiteit Limburg, 1993

Ezzamel, M., K. Hoskin en R. Macve, Managing it all by numbers: A review of Johnson \& Kaplan's 'Relevance Lost', Accounting and Business Research, 1990, vol. 20, nr. 78, pag. $153-166$

Feenstra, D.W. en J.H.R. van de Poel, Financieel-economische berichtgeving, oordeelsvorming en besluitvorming, Maandblad voor Bedrijfsadministratie en -Organisatie, 1986, pag. 290-294

Feltham, G.A., The Value of Information, The Acounting Review, oktober 1968, pag. 684-696

Financial Accounting Standards Board, FASB Discussion Memorandum: Conceptual Framework for Financial Accounting and Reporting: Elements of Financial Statements and Their Measurement, 1976(a)

Financial Accounting Standards Board, Scope and Implications of the Conceptual Framework Project, 1976(b)

Financial Accounting Standards Board, Tentative Conclusions on Objectives of Financial Statements of Business Enterprises, 1976(c)

Financial Accounting Standards Board, Objectives of Financial Reporting by Business Enterprises, Statement of Financial Accounting Concepts No.1, 1978 Financial Accounting Standards Board, Qualitative Characteristics of Accounting Information, Statement of Financial Accounting Concepts No.2, 1980-1 Financial Accounting Standards Board, Elements of Financial Statements of Business Enterprises, Statement of Financial Accounting Concepts No. 3, 1980-2 
Financial Accounting Standards Board, Recognition and Measurement in Financial Statement of Business Enterprices, Statement of Financial Accounting Concepts No. 5 , 1984

Financial Accounting Standards Board, Elements of Financial Statements: A Replacement of FASB Concepts Statement No. 3, Statement of Financial Accounting Concepts No. 6,1985

Flamholtz, E.G., Accounting, Budgeting and Control Systems in Their Organizational Context: Theoretical and Empirical Perspectives", Accounting, Organizations and Society, 1983, pag. 147-151

Flamholtz, E.G., Relevance regained: management accounting- past, present, and future, Advances in Management Accounting, volume 1, 1992, pag. 21-34

Foster, G. en C.T. Horngren, Cost Accounting en Cost Management Issues, Management Accounting, 1987, pag. 19-25

Fox, R.P., Agency Theory: a new perspective, Management Accounting, februari 1984

Fox, R.E. en E.M. Goldratt, The Fundamental Measurements, The Accounting Systems Journal, 1989, vol. 1, nr. 1, pag. 18-31

Fraser, I.A.M. en C.W. Nobes, The Assumed Users in Three Accounting Theories, Accounting and Business Research, lente 1985, pag. 144-147

Fraser, I.A.M., Triple-entry Bookkeeping: A Critique, Accounting and Business Research, 1993, vol. 23, no. 90 , pag. 151-158

Fröhling, O. en A. Wullenkord, Das Japanische Rechnungswezen ist viel stärker Marktund Strategie orientiert, Management Zeitschrift, maart 1991

Gailbraith, J.R., Designing complex organizations, 1973

Gennep, G.P.P.M. en A.M.M. Blommaert, Pensioenen en rekenrente in de jaarrekening, een verkennend onderzoek naar de invloed van de pensioenrekenrente op de jaarrekening, Maandblad voor Bedrijfsadministratie en -Organisatie, 1990, pag. 154-160

Gleick, J., Chaos, De derde wetenschappelijke revolutie, (vertaling) 1987

Goldratt, E.M. en J. Cox, The Goal, 1986

Goldratt, E.M. en R.E. Fox, The Haystack syndrom, 1991

Gorbatsjov, M., Perestrojka, een nieuwe visie voor mijn land en de wereld, (vertaling) 1987

Gordon, L.A., D.F. Larcker en F.D. Tuggle, Strategic decision processes and the design of accounting information systems: conceptual linkages, Accounting, Organizations and Society, 1978, vol. 3, no. 3/4, pag. 203-213

Gordon, L.A. en V.K. Narayanan, Management Accounting Systems, Perceived Environmental Uncertainty and Organization Struture: An Empirical Investigation, Accounting, Organizations and Society, 1983, vol. 9, nr. 1, pag. 33-47 
Hagerman, R.L., Accounting in the Bible, 1980, The Accounting Historians Journal, herfst 1980, pag. 71-75

Hamid, S., Craig R. en Clarke F., An antecedent of double-entry bookkeeping: The accounting system of a tenth century Muslim administrative office, paper, 1993, pag. $1-20$

Hartman, W., Typologie en mosselcultuur, De Accountant, februari 1993

Hartog, P.A., A. Molenkamp en J.H.M. Otten, Kwaliteit van Administratieve Dienstverlening (Managen is integreren), 1992

Have ten, O., De geschiedenis van het boekhouden, 1973

Hayes, D.C., Accounting for Accounting: A story about Managerial Accounting, Accounting, Organizations and Society, 1989, vol. 8, no. 2/3, pag. 241-249

Hedberg, B., On Man-Computer Interaction in Organizational Decision Making, 1973

Hernandez-Esteve, E., Comments on some obscure or ambiguous points of the treatise de computis et scripturis by Luca Pacioli, paper, 1993, pag. 1-68

Hicks, J.O. jr., Management Information Systems, A User Perspective, 1984

Hicks, J.O. jr. en W.E. Leininger, Accounting Information Systems, 1986

Hiromoto, T., Another hidden edge - Japanese management accounting, Harvard Business Review, 1988, nr. 5, pag. 22-26

Hirsch, M.L., Advanced management accounting, 1988

Hodge, B. en J.P. Clements, Business Systems Analysis, 1986

Hofstede, G.H., The Game of Budget Control, 1967

Hofstede, G.H., The Poverty of Management Control Philosophy, Academy of Management Review, juli 1978, pag. 450-461

Hofstede, G.H., Management Control of public and not-for-profit activities, Accounting, Organizations and Society, 1981, vol. 6, nr. 2, pag. 193-211

Hofstede, G.H., The Ritual Nature of Accounting Systems, paper, EIASM, 1985, pag. 1-10

Holzhauer, F.F.O. en J.J.R. van Minden, Psychologie, theorie en praktijk, 1985

Hopper, T., Social transformation and management accounting, in: Proceedings of the Second Interdisciplinary Perspectives in Accounting Conference, 1988

Hopper, T., L. Kirkham, R.W. Scapens en S. Turley, Does financial accounting dominate management accounting- a research note, Management Accounting Research, 1992, 3 , 307-311

Hopwood, A.G., Behavioral Research in Accounting: An Overview of an Overview, Accounting, Organizations and Society, 1975, vol. 8, nr. 2/3, pag. 40-47

Hopwood, A.G., On trying to study accounting in the contexts in which it operates, Accounting, Organizations and Society, 1983, vol. 8, nr. 2/3,

Hopwood, A.G., The archaeology of accounting systems, Accounting, Organizations and Society, 1987, vol. 12, nr. 3, pag. 207-232 
Horngren, C.T., Management Accounting: Where are we?, Management Accounting and Control, 1975

Horngren, C.T. en G.L. Sundem, Introduction to financial accounting, 1990

Hoskin, K. en R.H. Macve, The genesis of accountability: the west Point connections, Accounting, Organizations and Society, 1988, vol. 13, no. 1, pag. 37-73

IFAC, Statements on International Management Accounting, handboek deel 2, hoofdstuk 12, 1989, pag. 13-15

Ijiri, Y. en R. K. Jaedicke, Reliability and Objectivity of Accounting Measurements, The Accounting Review, juli 1966, pag. 478-483

Ijiri, Y., Physical Measures and Multi-Dimensional Accounting, Research in Accounting Measurement, American Accounting Association, 1966

Ijiri, Y., The Foundations of Accounting Measurement, 1967

Ijiri, Y., Theory of Accounting Measurement, American Accounting Association, Studies in Accounting Research No. 10, 1975

Ijiri, Y., Triple-Entry Accounting and Income Momentum, American Accounting Association, Studies in Accounting Research No. 18, 1982

Ijiri, Y., A Framework for Triple-Entry Bookkeeping, The Accounting Review, oktober 1986

Ijiri, Y., Three Postulates of Momentum Accounting, Accounting Horizons, maart 1987 Ijir, Y., Momentum Accounting and Triple Entry Bookkeeping: Exploring the dynamic structure of Accounting Measurements, American Accounting Association, Studies in Accounting Research No. 31, 1989

Ijiri, Y., The Beauty of Double-Entry Bookkeeping and its Impact on the Nature of Accounting Information, in: Economic Notes by Monte dei Paschi di Siena, vol. 22, no-2-1993, pag. 265-285

Inoue, K., "Threefold Bookkeeping" by Matthäus Schwarz, The Accounting Historians Journal, 1982, vol. 9., no. 1, pag. 39-51

Institute of Chartered Accountants of Scotland, Making Corporate Reports Valuable, 1988 Institute of Chartered Accountants of Scotland, The Flaming Torch, Chapter 1: Luca

Pacioli, the Perfect Acountant by F. G. Volmer, 1994, pag. 1-18

International Accounting Standards Committee (IASC), Framework for the Preparation and Presentation of Financial Statements, juli 1989

In 't Veld, J., Manager en informatie, Informatiesystemen met of zonder computer, 1986 Izeboud, C., Management accounting na Limperg: de (gewenste) ontwikkeling in de praktijk, Stichting Moret Fonds, Limperg-dag 1991, 1992, pag. 27-38

Iwabuchi, Y., N. Shimizu en M.L. Shrestha, Self-Organization through the Target Cost Management in Japanese Firms, paper, EAA 1994, Venetië, pag. 1-10 
Jensen, M.C. en W.H. Meckling, Theory of the firm: Managerial Behavior, Agency costs, and Ownership Structure, Journal of Financial Economics, oktober 1976

Johnson, H.T., Towards a New Understanding of Nineteenth-Century Cost Accounting, The Accounting Review, 1981, vol. 16, no. 3, pag. 510-518

Johnson, H.T. en R.S. Kaplan, Relevance lost, The Rise and Fall of Management Accounting, 1987

Johnson, H.T. en R.S. Kaplan, Relevance lost, The rise and Fall of Management Accounting, Management Accounting, januari 1987, pag. 22-30

Johnson, H.T., Beyond product costing: a challenge to cost management's conventional wisdom, Journal of Cost Management, herfst 1990, pag. 15-21

Johnson, H.T., Relevance regained: From top-down control to bottum-up empowerment, 1992

Jones, C.S., Organisational Change and the Functioning of Accounting, Journal of Business Finance \& Accounting, najaar 1986, pag. 283-310

Jong, de F.J., Developments of monetary theory in the Netherlands, 1973 Jong, de F.J., Dimensieanalyse in de economie, De Economist, 110, nr. 1/2, 1962, pag. 111-206

Kandelin, N.A. en T.W. Lin, A Computational Model of An Events-Based ObjectOriented Accounting Information System for Inventory Management, paper, American Accounting Association, 1992, pag. 1-44

Kaplan, R.S., Cross-Fertilization of Accounting Research and Practice, paper, Arthur Young Professors' Roundtable, 1981

Kaplan, R.S., Advanced management accounting, 1982

Kaplan, R.S., Measuring Manufacturing Performance: A New Challenge for Managerial Accounting Research, The Accounting Review, 1983, vol 18. no. 4, pag. 686-705 Kaplan, R.S., Yesterday's accounting undermines production, Harvard Business Review, juli-augustus 1984, pag. 95-101

Kaplan, R.S., The Evolution of Management Accounting, The Accounting Review, 1984, vol. 59, no. 3, pag. 390-418

Kaplan, R.S., Research Cultures in Managerial Accounting: Empirical Research, paper, 1986, pag. 1-21

Kaplan, R.S., One Cost System isn't Enough, Harvard Business Review, januari-februari 1988, pag. 61-66

Kaplan, R.S., Activity Based Costing legt nieuwe fundamenten, Controllers Magazine, nr. 8, december 1990, pag. 10-15

Kaplan, R.S. en A.A. Atkinson, Advanced management accounting, 1989 Kelley, A.C., Is Accountancy A Science?, The Accounting Review, 1941, vol. 16, no. 3, pag. 231-234 
Kelly, Business Week, 1988

Kerlinger, F.N., Foundations of Behavioral Research, 1986

Khandwalla, P., The Effect of Different Types of Competition on the use of Management Controls, Journal of Accounting Research, herfst 1972, pag. 275-285

King, M., R.A. Lee, J.A. Piper en J. Whittaker, Information Technology and the Changing Role of Management Accountants, in: Issues in Management Accounting, 1991, pag. 294-311

Kirk, D.J., Competitive Disadvantage and Mark-To-Market Accounting, Accounting Horizons, juni 1991, pag. 98-106

Klaassen, J. en G.G.M. Bak, Externe Verslaggeving, 1993

Klaassen, J. en G.H. Zevenboom, De nieuwe jaarverslaggeving, Een gebruikershandleiding, 1993

Klant, J.J., Filosofie van de economische wetenschappen, 1987

Kleijnen, J.C.P., Computers and Profits, 1980

Knoops, C.D., Recente ontwikkelingen in financial en management accounting (11), Pacioli Journaal, 1991, pag. 45-47

Knoops, C.D., Naar een taxonomie van accounting theorieën, Maandblad voor Accountancy en Bedrijfseconomie, februari 1993

Kroes, Filosofie van de natuurkunde, 1987

Krom, J.P.J., Luca Pacioli, priester en de dogen van Venetië: De geboorte van een beroep, Pacioli Journaal, 1992, pag. 8-10

Kuhn, Th.S., The Structure of Scientific Revolutions, 1970

Kuijl, J.G., Geven en nemen, Fiscale aspecten van de wetgeving op de jaarrekening in historisch perspectief, inaugurele rede, Rijksuniversiteit Leiden, 1990

Kunst, P. en H. Schreuder, Opening up the concept of control, working paper, Rijksuniversiteit Limburg, 1988

Lall Nigam, Bahi-Khata: The Pre-Pacioli Indian Double-entry System of Bookkeeping, Abacus, 1986, vol. 22, no. 2, pag. 148-161

Langendijk, H.P.A.J., J.G. Kuijl en A. Smeenge, Financiële administratie 2, 1990

Lee, L.A., Psychological Aspects of Accounting, Accounting and Business Research, zomer 1972, pag. 223-233

Lee, T.A., L. Goldberg en T. Johnston, 'The History of Accounting': Three Reviews, Accounting and Business Research, 1977, pag. 58-67

Lee, J.Y., Managerial accounting changes for the 1990s, 1987

Leech, S.A. en M.J. Mepham, A relational/matrix framework for accounting, paper, 1990

Leeflang, P.A.H., Informatieverzorging en enkele kernproblemen in de marketing, in: Ontwikkelingen rond informatiesystemen, 1984, pag. 229-245

Lewis, B., M.D. Shields en S.M. Young, Evaluating Human Judgments and Decision Aids, Journal of Accounting Research, 1983, vol. 21, no. 1, pag. 271-285 
Lewy, C.P., Management Control Regained, De financieel/economische beheersing van complexe organisaties - een integratie van theorie en praktijk, 1992

Libby, R. en B.L. Lewis, Human Information Processing Research in Accounting: The State of the Art in 1982, Accounting, Organizations and Society, 1982, vol. 7, no. 3, pag. 231-285

Liempt, van A.G.H., A. De Jong, H. Beckman en M.H.A.F. van Summeren, Voortgezette Studie in het Boekhouden, deel 2, 1989

List, W., Exit double entry?, The Accountant's Magazine, september 1986

Lister, R.J., Werner Sombart's 'Der moderne Kapitalismus: An Apotheosis of Double-

Entry Accounting?, Accounting and Business Research, 1985, pag. 229-231

Littleton, A.C., Accounting Evolution to 1900, 1933

Loft, A., The History of Management Accounting: Relevance Found, in: Issues in

Management Accounting, 1991, pag. 17-38

Lowry, J., Management Accounting's diminishing post-industrial relevance: Johnson and Kaplan revisited, Accounting and Business Research, 1993, vol. 23, no. 90, pag. 169179

Markus, M.L. en J. Pfeffer, Power and the Design and Implementation of Accounting Control Systems, Accounting, Organizations and Society, 1983, pag. 205-218 Marx, K., Het Kapitaal, een kritische beschouwing over de economie, deel 1 (het produktieproces van het kapitaal), vertaling, 1975

Mattessich, R., On the Evolution of Theory Construction in Accounting: a Personal Account, Accounting and Business Research, 1980, pag. 158-170

McCarhty, W.E., The REA Accounting Model: A Generalized Framework for Accounting Systems in a Shared Data Environment, The Accounting Review, 1982, pag. 554-578 McGhee, W., M.D. Shields en J.G. Bimberg, The Effects of Personality on a Subject's Information Processing, The Accounting Review, 1978, no. 3, pag. 681-697

McIntyre, E.V., Current-cost Financial Statements and Common-stock Investments Decisions, The Accounting Review, juli 1973

McKinnon, W.P. en E.A. Kallman, Mapping Chargeback Systems to Organizational Environments, MIS Quarterly, maart 1987, pag. 5-20

McMcikle, P.L., Accounting Systems: Past, Present, And Future, The Accounting Systems Journal, augustus 1989, vol. 1, nr. 1, pag. 1-3

Mclean, T., Management accounting: relevance lost?, The Accountant's Magazine, september 1987, pag. 54-55

Mednick, R., The future of auditing, a vision from the US, Maandblad voor accountancy en bedrijfseconomie, december 1992

Merchant, K.A., An Investigation into the reasons for firms' selective disregard of the controllability principle, paper, American Accounting Association, 20 augustus 1986 
Merchant, K.A., Rewarding results, Motivating profit centre managers, Harvard Business School, 1989

Merchant, K.A., The Effects of Financial Controls on Data Manipulation and Management Myopia, Accounting, Organizations and Society, 1990, vol. 15, nr.4, pag. 297-313

Meuwissen R., De meting en de omvang van accountantskantoren: een empirische studie, research memorandum, Rijksuniversiteit Limburg, 1992

Miles, R.E. en C.C. Snow, Organizational Strategy, Structure and Process, 1978

Miller, P., T. Hopper en R. Laughlin, The New Accounting History: An Introduction, Accounting, Organizations and Society, 1991, vol. 16, no.5/6, pag. 395-403

Miller, D. en P.H. Friessen, Innovation in Conservative and Entrepreneurial Firms, Strategic Management Journal, 1982, pag. 1-27

Mintzberg, H., Structures in fives, designing effective organizations, 1983

Mintzberg, H., Mintzberg on Management, 1989

Mock, T.J., The Evaluation of Alternative Information Structures, 1969

Mock, T.J., Measurement and Accounting Information Criteria, 1976, pag. 1-116

Moon, P., Some experimental evidence on functional fixation: a research note,

Accounting, Organizations and Society, vol, 15, 1990, pag. 193-198

Motz, L. en J.H. Weaver, Geschiedenis van de natuurkunde, (vertaling), 1993

Mullins, L., Behavioral implications of management accounting, Management Accounting, 1981, pag. $36-39$

Nakanishi, A., On The Life of Luca Pacioli, The Accounting Historians Journal, 1979, vol. 6 , no. 2, pag. 53-59

National Association of Accountants, Management Accounting Practices Committee, Statement on Management Accounting No 1A, "Definition of Management Accounting, 1981

Needles, B.E., H.R. Anderson en J.C. Caldwell, Financial \& Managerial Accounting, 1988

Nera (National Economic Research Associate), rapport: Competition in Economic Accounting, 1992

Newbold, P., Statistics for business and economics, 1984

Newell, A. en H.A. Simon, Human Problem Solving, 1972

Olders, E.A.M., Momentum accounting: The Derivation and Application of New Accounting Dimensions, doctoraalscriptie, Rijksuniversiteit Limburg, 1993 Oliver, B.L., M.L. Bariff en B.J. Calder, Behavioral Research on Accounting, An Overview of What's Been Happening, Accounting, Organizations and Society, 1975, pag. $30-38$ 
Oppelland, H.J., Informatiesystemen - belangrijk hulpmiddel voor het besturen van organisaties, Pacioli Journaal, januari 1990, pag. 3-6 Oonincx, J.A.M., Waarom falen informatiesystemen nog steeds?, 1982 Oorschot van, J.M., Visie op Informatiebeleid, NIVE, 1985, pag. 1-23

Page, J. en P. Hooper, Accounting and Information Systems, 1982 Parkinson, J.M., The implications of triple-entry bookkeeping, Management Accounting. mei 1987

Peters, H.J.M., Bargaining game theory, 1986

Peters, T.J. en R.H. Waterman, In Search of Excellence: Lessons from America's BestRun Companies, 1982

Peters, T.J., Liberation management, necessary disorganization for the nanosecond nineties, 1992

Peursen, C.A. van, Filosofie van de wetenschappen, 1986

Poel van de, J.H.R., Judgment and Control, Individual and Organizational Aspects of Performance Evaluation (dissertatie Rijksuniversiteit Groningen), 1986

Poel van de, J.H.R., Kosten en strategie, een inleiding over transactiekosten en hun toepassing in de berichtgeving, Maandblad voor Bedrijfsadministratie en -Organisatie, 1991, pag. 202-205

Porter, G.L. en M.D. Akers, In Defense of Management Accounting, Management Accounting, november 1987, pag. 58-62

Porter, M.E., Competitive strategy, 1980

Porter, M.E., Competitive advantage: Creating and Sustaining Superior Performance, 1985

Prakash, P. en A. Rappaport, Information Inductance and Its Significance for Accounting, Accounting, Organizations and Society, 1977, pag. 29-38

Pryor, T.E., Activity Accounting: The Key to Waste Reduction, The Accounting Systems Journal, 1989, vol.1, nr. 1, pag. 32-38

Puxty, A.G. en P. Pope, The relevance of research in accounting and finance, The Accountant's Magazine, 1989, pag. 25-26

Puxty, A.G., The Social \& Organizational Context of Management Accounting, 1993

Rendel, P., Over chakra's, 1989

Roberts, H.J.E., Accountability and Responsibility (dissertatie Rijksuniversteit Limburg), 1993

Roest, R., Inleiding mechanica, 1987

Roover de, R., Paciolo or Pacioli, The Accounting Review, 1943, pag. 68-69

Ross, G., The Revolution in Management Control, CMA Magazine, oktober 1990, pag. 46-51 
Samuelson, P.A., Economics, 1983

Scapens, R.W., Management Accounting, A Review of Recent Developments, 1985

Scherpenzeel, M.W., Management accounting belangrijker dan ooit, Finance, december 1991

Schilder, A., Onderzoekt alles..., inaugurele rede, Rijksuniversiteit Limburg, 1989

Scholtes, E., De verborgen dimensie in het werk van Jung en Pauli, 1991

Schreuder, H., Economic Theories of Organizations: An overview and assessment of some recent development, Research memorandum, Rijksuniversiteit Limburg, 1985

Schreuder, Economie (en) Bedrijven, inaugurele rede, Rijksuniversiteit Limburg, 1985 Scorgie, M.E., Early Arithmetics and Accounting Histories: A Comment, Abacus, 1991, vol. 27, no. 1, pag. 78-80

Scorgie, M.E. en S. Chandran, Emerging Evidence of Early Indian Accounting, Abacus, 1992, vol. 28., no. 1, pag. 88-97

Schuyt, C.J.M., Filosofie van de sociale wetenschappen, 1986

Shank, J.K. en V. Govindarajan, Strategic cost analysis, the evolution from managerial to strategic accounting, 1989

Siegel, S. en N.J. Castellan jr., Nonparametric Statistics for the behavioral sciences, 1988 Siegel, G. en H. Ramanauskas-Marconi, Behavioral Accounting, 1989

Simmonds, K., The Fundamentals of Strategic Management Accounting, The Institute of Cost and Management Accountants, 1981, pag. 1-14

Simons, R., Planning, Control, and Uncertainty: A Process View, in: Accounting \& Management, Field Study Perspectives, 1987

Slater, K., Performance measurement in the finance function, Management Accounting, mei 1991

Snowball, D., Accounting laboratory experiments on human judgment: some characteristics and influences, Accounting, Organizations \& Society, mei 1986

Solomon, L.M., R.J. Vargo en L.M. Walther, Accounting Principles. 1986

Sorter, G.II., An 'Events' Approach to Basic Accounting Theory, The Accounting Review, januari 1969, pag. 12-19

Spicer, B.H., Herrijzenis management accounting en kostencalculatie (vertaling), Tijd schrift voor Financieel Management, 1992/6, pag. 62-70

Stamp, E., First Steps towards a British conceptual framework, Accountancy, mei 1982

Starreveld, R.W., H.B. de Mare en E.J. Joëls, Bestuurlijke Informatie Verzorging, deel 1, 1990

Stevelinck, E., Accounting in Ancient Times, The Accounting Historians Journal, 1985, vol. 12, no. 1, pag. 1-14

Stolowy, H., J-C. Dormagen en M. Ternisien, The "Unified Accounting System": How to implement on-line cash flow accounting, paper, 1993, pag. 1-24

Swanborn, A., Methoden van sociaal wetenschappelijk onderzoek, 1987 
Swieringa, R.J. en K.E. Weick, An assessment of Laboratory Experiments in Accounting, Journal of Accounting Research, vol. 20, 1983, pag. 56-101

Taylor, R.E., The Name of Pacioli, The Accounting Review, 1943, pag. 69-76

Tas, L.G. van der, Harmonisation of Financial Reporting (dissertatie Erasmus Universteit Rotterdam, 1993

Thompson, V.A., Bureaucracy and Innovation, Administrative Science Quarterly, 1965, pag. 1-20

Thomsen, C.T., The deep structure of an innovative Accounting Information System, paper, International Congres on Information Systems, 1991, New York

Thomson, H.W. en B.S. Yamey, Bibliography of Bookkeeping and Accounts-1494 to 1650-, bron en jaartal onbekend, pag. 239-257

Tversky, A. en D. Kahneman, Judgment under uncertainty: heuristics and biases, Science, 1974, vol. 185, pag. 1124-1131

U.S. Treasury, 1991

Vaassen, E. en A.M.M. Blommaert, Knelpunten bij regelgeving, een inventarisatie van de problematiek inzake het uitvaardigen van voorschriften m.b.t. te publiceren jaarrekeningen, Maandblad voor Bedrijfsadministratie en -Organisatie, 1987, pag. 320-324 Vatter, J.V., Managerial accounting, 1950

Veeken, v.d. H.J.M, M.H. Corbey en M.J.F. Wouters, Administratieve knelpunten belemmeren innovatie van management accounting, Maandblad voor Accountancy en Bedrijfseconomie, april 1993, pag. 171-178

Vernooij, A.T.J., De toetsende tucht van de dimensionele analyse, Maandblad voor Accountancy en Bedrijfseconomie, oktober 1993, pag. 462-471

Volmer, F.G., Enige beschouwingen met betrekking tot de gemeenterekening, 1992 Vlotman, F.W., Management Accounting als adviesterrein, De Accountant, december 1990

Vries de, J., Geschiedenis der Accountancy in Nederland, 1985

Walgenbach, P.H., Dittrich N.E. en Hanson E.I., Principles of Accounting, 1984

Walker, C.B.F., Reading the past, Cuneiform, British Museum, 1987

Wallage, Ph. en J.J. Tijhuis, Controller en registeraccounting; een sterk team?, Controllersvizier, 1992/1, pag. 8-12

Walsch, E.J. en R.E. Stewart, Agency Theory and Management Accounting: A Historical Perspective, paper, 1987, pag. 1-31

Waterhouse, J.H. en P. Tiessen, A Contingency Framework for Management Accounting Systems Research, Accounting, Organizations and Society, 1978, vol. 3, nr. 1, pag. 6576 
Watts R.L. en J.L. Zimmerman, Positive Accounting Theory, 1986

Weber, J.E., Mathematical Analysis, Business and Economic Applications, 1982

Weezenberg, J.N., Trendmatige ontwikkelingen binnen de bedrijfskunde, in: Bedrijfskunde op weg naar 1990, 1989, pag. 79-90

Whittington, G., Positive Accounting: A Review Article, Accounting and Business

Research, 1987, vol. 17, nr. 68, pag. 327-336

Williamson, O.E., Markets and Hierarchies, 1975

Wilson, R.M.S., Strategic Management Accounting, in: Issues in Management Accounting, 1991, pag. 82-105

Wisse, P.E., Relationeel boekhouden, scheiding van registratie en rapportage,

De Accountant, september 1992

Wolk, H.I., F.R. Francis en M.G. Tearney, Accounting Theory, A Conceptual and Institutional Approach, 1992

Yamey, B.S., Art \& Accounting, 1989

Yamey, B.S., Early Views on the Origins and Development of Book-keeping and Accounting, Accounting and Business Research, 1980, pag. 81-92

YoshiKawa, T., J. Innes, F. Mitchell en T. Tanaka, Contemporary Cost Management, 1993

Zimmer, I., A Lens Study of the prediction of Corporate Failure by Bank Loan Officers, Journal of Accounting Research, 1980, vol. 18., no. 2 


\title{
Curriculum vitae
}

\begin{abstract}
AMM (Tjeu) Blommaert werd op 7 maart 1955 te Susteren geboren.
Na zijn middelbare schoolopleiding ging hij te Tilburg studeren voor de MO-(B)akte Handelswetenschappen. Deze opleiding rondde hij in 1977 af. Gedurende zijn opleiding alsmede daarna is hij als docent bedrijfsadministratie en bedrijfseconomie verbonden geweest aan het Bisschoppelijk College te Sittard en aan het HEAO te Sittard (waar hij als examen-gecomitteerde nog enkele jaren aan verbonden is gebleven). Ook is hij docent Handelswetenschappen geweest aan de Katholieke Leergangen te Tilburg en docent PDB en MBA aan het AvondCollege te Sittard. Vele jaren heeft hij deel uitgemaakt van diverse examencommissies en heeft hij meerdere redacteurschappen van vakbladen bekleed. In 1982 verscheen zijn eerste boek (Gestructureerd Consolideren; in samenwerking met zijn broer JMJ Blommaert). Na dit boek volgden nog vele andere boeken en overige vakpublikaties op bedrijfseconomisch en administratief gebied.
\end{abstract}

In januari 1985 trad hij in dienst bij de Rijksuniversiteit Limburg, Economische Faculteit. Thans is hij voor 0,5 functie als universitair docent bedrijfseconomie aan deze instelling verbonden. Overigens is hij als adviseur op bedrijfseconomisch en administratief gebied in het bedrijfsleven werkzaam. 


\section{Over Ijiri}

Yuji Ijiri werd in 1987 Robert M. Trueblood hoogleraar aan de Carnegie Mellon universiteit te Pittsburgh aan welke universiteit hij in 1963 zijn proefschrift voltooide. Zijn universitaire opleiding genoot hij in Japan (Ritsumeikan University in Kyoto) waar hij in 1956 ook het CPA-examen afrondde.

In 1986 kreeg Ijiri van de American Accounting Association de waardering van 'beste docent bedrijfseconomie'. Al 4 keer ontving hij als enige van het American Institute of Certified Public Accountants de prijs in de categorie 'buitengewone bijdrage tot de economische literatuur'. Hij is oud voorzitter van de American Accounting Association (1982-83) en de enige auteur die drie publikaties van studies in accounting research onder sponsoring van genoemde associatie op zijn naam heeft staan (1975, 1982 en 1989). De laatste twee publikaties handelen beide over triple-entry en momentum accounting. Zijn totale oeuvre, boeken en artikelen in internationale tijdschriften, beslaat op dit moment zo'n 200 publikaties.

In een brochure die de Carnegie Mellon uitgeeft in het kader van studentenwerving wordt het werk van Ijiri - 'the development of a triple entry system of accounting ('momentum accounting') for improved measurement and control of managerial performance' gebruikt als een van de mogelijke redenen om aan deze faculteit de studie economie op te pakken. De faculteit staat 'at the forefront of exellence' en het werk van ljiri wordt geclassificeerd onder 'major breakthroughs in management accounting theory and practice' (1993: 5-23). 


\section{Summary and conclusions}

Current accounting research and practice is still based on the double entry accounting framework provided by Pacioli about 500 years ago (Pacioli's Summa de Arithmetica et de Proportione et Proportionalita is dated November the 20th 1494). ${ }^{1,2}$ This thesis highlights some important events in accounting history as it has developed from singleentry accounting to double-entry accounting and then to cost accounting, financial accounting, and management accounting and finally to three-dimensional accounting (see chapter 3).

At a time when the 'state of the art' in management accounting is being criticized in literature and practice (see chapter 3 ) it is legitimate to ask whether the conventional management accounting model is still adequate to capture today's economic events and to provide the information needed to support justified decision making. ${ }^{3}$ Theorists suggests that management accounting has lost its relevance because of the financial accounting mentality. Others suggest that this is because too little weight is given to the behavioural aspects of accounting. In chapter 4 both views are discussed in some detail. Whatever may be the case, it is clear that management accounting needs a revival. This could be realized through an adjustment to the old accounting framework of Pacioli, which, it is argued, is not adequate to discharge the accounting function in today's environment. ${ }^{4}$ Some recent developments in management accounting, such as activity based costing and strategic cost accounting, are introduced as new accounting approaches which are needed to recover accountings's relevance. But in fact these new ideas would all be implemented if the traditional accounting framework were to be modified in a certain way. The potential of Ijiri's triple-entry and momentum accounting system to solve the problems that accountants are faced with has been under-appreciated. In fact this system is derived from physics, sometimes called the science of science. For this reason it is necessary to describe the most important happenings in the history of physics so far as these are relevant to accounting.

Historically the study of moving objects (i.e. classical mechanics) has been one of the most discussed topics within physics. Mechanics embraces several subdivisions: kinematics, which analyses motions without examining the causes of motion, and dynamics.

\footnotetext{
1 Some authors have found evidence that Pacioli was not the original writer.

2 There is also some evidence that the Indian Bahi-Khata system predates the Italian system by many centuries.

3 This is especially true with regard to the sophisticated electronic technology that is available nowadays.

4 This does not necessarily mean that triple-entry and momentum accounting concepts have any meaning in a financial accounting context, but on the other hand these concepts might change financial accounting practice as well.
} 
Dynamics is subdivided into

1) statics and

2) kinetics, which studies motion in relation to its causes. ${ }^{5}$

In brief, there are three main approaches to the study of moving objects: (1) the Aristotelian approach, (2) the Newtonian approach ${ }^{6}$ and (3) the new approach (of which Einstein is the best known representative). From an accounting perspective the Newtonian idea is most relevant.

Aristotle (384-322 B.C.) supposed that an object moves only if it is forced to do so. When the impulse is exhausted the object ceases its motion. ${ }^{7}$ This means that the Aristotelian approach to motion is discontinuous. Given his historical context, it is not surprising that Pacioli's double-entry framework corresponds to an Aristotelian concept of the physical universe. ${ }^{8}$ It was Leonardo Da Vinci (1452-1519), a friend of Lucas Pacioli, who first studied the acceleration of falling objects. Galilei (1564-1642) improved on Da Vinci's ideas by analyzing many experiments.

Newton (1643-1727) abandoned all these models of motion when he introduced his inertia or momentum concept: in the absence of friction an object forced into motion would move indefinitely. Not discontinuity, as in the Aristotelian model, but continuity is the starting point. From an accounting point of view this means, for example, that one would consider the expected increase in annual net income forecast to result from an advertising campaign as a continuous increase. Hence we should discuss the financial impact of this campaign in terms of income per year, which is the income momentum (or the net income capacity) as measured at a given time. It is the rate at which income is earned over time. ${ }^{9}$ If a $\$ 30,000$ computer-maintenance contract is signed in September $199 \mathrm{X}$, the traditional wealth accounting system only captures the $\$ 10,000$ in expenses that is matched to the $199 \mathrm{X}$ financial statements. From a momentum accounting perspective the income power decreases by $\$ 30,000$ per year and this amount is entered in the system. ${ }^{10}$ This information may be very important to predict the $199 \mathrm{X}+1$ income. From a momentum accounting viewpoint and from the standpoint of performance evaluation the payments made under this contract are in fact irrelevant (non-events) because these do not change the company's financial inertia. Within the conventional system a 'status quo' situation would mean that no accounting events have occurred. This means that wealth has remained unchanged. In momentum accounting, 'status quo' means that this year's

\footnotetext{
5 The $\mathrm{ABC}$ system is analogous to kinetic studies, as it is designed to detect cost drivers.

6 The Aristotelian approach and the Newtonian approach together may be called 'the classical approach of physics'.

7 More generally 'motion' is called 'action'. Hence action is a force integrated over time.

${ }^{8}$ Pacioli refers to Aristorle in his Summa as he calls him 'the Philosopher'.

9 Income momentum integrated over time gives income.

10 The momentum accountant is thus much more future-oriented than the wealth accountant.
} 
net income is equal to last year's income. This means that the net wealth increase has remained unchanged. ${ }^{11}$

The concept of accounting for momentum as it is discussed in chapter 7 is not really unfamiliar. The speedometer of a car, for instance, accounts for three things. The mileometer records the total number of miles travelled: this is a cumulative figure. There is a separate trip meter that captures the miles covered during a certain drive or day. The speedometer registers the actual speed at which the car is currently driving. If the speedometer indicates 40 miles per hour of constant driving, for 10 hours a day, the trip meter shows 400 miles each day while the mileometer shows 400 miles, 800 miles, 1,200 miles etc.. In fact this is the reporting mechanism that is used within the conventional accounting system. It does not report acceleration. Information about these changes in speed, which in an accounting context may be compared to changes in the rate at which net income is earned, refer to the third dimension in the triple-entry accounting system. Within this system a different concept of income is used: the discrete concept of income is set aside and the continuous concept is applied.

The momentum accounting system administers data about financial events that are not entered in the conventional system. New wage contracts, new interest rates, changes in investments etc. are all events that are irrelevant from the traditional viewpoint but whose expected financial impacts are recorded systematically within the momentum accounting system. This momentum accounting system is mathematically related to the double-entry accounting system. ${ }^{12,13}$

Einstein (1879-1955) introduced the relative meaning of time and space within the physical measurement of motion. One might say that this approach has been given shape in the strategic accounting strand, in which the traditional accounting boundaries are relaxed so that competitive information can be provided (cross-sectional comparisons).

From a certain point of view, far from the behavioral concept of the firm, a company may be compared to a moving object. The company's goal may be to go from one point

\footnotetext{
11 In financial management it is becoming more and more usual to value securities from their earnings momentum. See the Value Line model. Also within general economics (sce the Fisher cquation) and within compound interest calculations it is common to make calculations that account for differences in the velocity of eaming money.

12 This relationship is based on time derivatives and time integrals.

13 It may be concluded that the framework of multi-dimensional accounting is infinitely extendable, e.g. 10 a quadruple entry accounting system. It is possible to add a fourth dimension to the triple-entry concept by taking the time integral of wealth instead of the time differential. In this context debts may be seen as negative assets, revenues as assets obtained and expenses as assets foregone. Analogous to the relationship between momentum and income. this is the realization of wealth which Ijiri denotes as 'wealth utilization' and the corresponding accounting system 'benefit accounting'. The utilization of wealth leads to a flow. Positive utilization of wealth increases the benefit level. The measurement unit is dollars per period ${ }^{-1}$.
} 
of net profit to another. The central object to be described in a profit accounting system is the position of, and changes in, owner's equity. In the single-entry accounting system the owners' equity position is the central dimension to be measured ${ }^{14}$ In practice this means that all the components of owner's equity need to be recorded. These components are the assets and all the debts and other obligations. Then the owner's equity volume (to be called 'wealth') can be determined by subtracting total debts and obligations from total assets. ${ }^{15}$ Hence the volume of owner's equity is found through a stock-taking of its components. From this it is concluded that 'owner's equity composition' is the first accounting dimension. The basic financial statement is the balance sheet, which enumerates all assets, liabilities and - on balance - the owner' equity at a certain point in time.

In order to look for the causes of motion, and to explain changes in position of the owner's equity, it became common to report on profit and loss events about the year 1400 A.D. Revenues and expenses and the net profit explained fully and systematically the increase or decrease in owner's equity from one time to another. By systematically recording revenues and expenses the owner's equity volume at any moment could now be determined directly using this updating mechanism: (1) beginning owner's equity $+(2)$ revenues - (3) expenses = ending owner's equity. ${ }^{16}$ The difference between beginning owner's equity and ending equity is earnings per period. Cumulated over time, these earnings must explain the owner's equity volume at any given time. From this point of view owner's equity volume is the second accounting dimension. This second dimension is expressed systematically in the profit and loss statement. Together with the indirect way of ascertaining the owner's equity volume (assets less liabilities), this means that the owner's equity can be determined in two different but related ways. Both approaches must lead to the same equity volume, providing a systematic internal check on the owner's equity volume that is expressed on the balance sheet. This explains the 'double' in the double-entry accounting system. ${ }^{17,18}$

Triple-entry accounting theory asks whether the two dimensions in use can be extended

14 Actually 'time' is a basic measuring unit and dimension as well.

15 To do so all assets and debts and obligations need to be expressed in financial terms. In former days (about 3000 B.C.) this was not common. All the owner's equity components were expressed in physical measures only. Sorter has picked up this aspect when he introduced his 'events approach' to accounting.

16 Capital transactions that influence owner's equity volume but cannot be regarded as income transactions, e.g. private withdrawals, an issue of shares or an asset revaluation, are excluded from this mechanism. Hence the focus is on income transactions.

17 This may be called a 'double-entry bookkeeping system' where the method of recording entrics is highlighted more than the valuation activities within the system.

18 Hence the 'double' in 'double-entry accounting system' has nothing to do with the common use of two entry columns (the debit and the credit) within the system. In a single-entry accounting system the use of two columns, debit and credit, is also quite usual. The use of two columns can be explained by the avoidance of negative numbers within the accounting system. This is a matter of form, not of content. 
to an accounting trinity. But what would the third dimension in a three-dimensional system be? Since the second dimension explains changes in position, the third dimension should explain change in change in position. This is change in earnings per period, or income acceleration. The third dimension or the third entry is related to changes in the rate of income realization. Under the double-entry accounting system it is supposed implicitly that income is realized within a certain period of time at a constant rate. But information about changes in this rate may be very relevant for predicting future earnings. ${ }^{19}$ The conclusion is that the third dimension relates to causal net income mutations. The reasons behind the net income difference are summed up in the so called action statement. The accounts in this statement are in money terms so they can be related to the profit and loss statement, just as the profit and loss statement accounts give reasons for changes in the owner's equity volume on the balance sheet. ${ }^{20}$ As a consequence the company's financial performance may be expressed in a vector, e.g. $(\$ 1,500$, 2,000 ). The first amount tells the user about the net income realized within a given period. The second amount indicates the firm's income momentum: it says the firm's net income potential is $\$ 2,000$ per year. Obviously not all the impulses have been realized within the reporting period.

To make up the action statement from the general ledger ('Quaderno Grande' as Pacioli called it) it is necessary to design new ledger accounts. These might be called 'Lowered interest rate', 'New wage contract', 'New competitors', 'General economic growth' etc.. Action, as a difference, is a result of impulse: action is impulse integrated over time. The impulses behind the actions are presented at the impulse statement. The force accounts on this statement are in dollars per month. ${ }^{21}$ An impulse which occurs causes a change in income momentum which is expressed on the momentum statement. And because income momentum integrated over time gives net income the impulse indirectly explains the change in net income. ${ }^{22,23}$ When looking for reasons behind net income mutations it may be relevant to relate them to the company's critical success factors. For profit is not

19 In this respect the third dimension is related emphatically to the earning power concept as it was introduced by Edwards and Bell.

${ }^{20}$ Ijiri calls this system a differential triple-entry accounting system. He also describes a temporal triple-entry accounting system wherein not the causal net income difference but the budget is the third dimension. As ljiri states himself, this temporal triple-entry accounting system is not a threefold system in essence. In fact the temporal system is a double-entry system which is applied twice. The budget dimension is not the integer to the existing two dimensions. However, because of its possible practical significance the temporal system is elaborated in detail in chapter 7.

21 Or any other relevant reporting period.

22 The only difference that may occur is a timing difference. An impulse that is measured per year and that occurred on October 1st would explain a net income difference of only $25 \%$ of the impulse, presuming the accounting period runs from 1 January to 1 January.

${ }^{23}$ From this point of view one could say that the differential triple-entry accounting system refers to profit variance analyses that are performed within the general ledger. 
the immediate result of a particular transaction, but rather the result of doing several things well. The most important 'things' can be termed the company's critical success factors. $^{24}$

To implement a triple-entry and momentum accounting system, it is necessary for the management accountant to break away from a financial accounting mentality dominated by information characteristics such as neutrality, objectivity and reliability. Other characteristics such as relevance, timeliness and feed forward may be more important. The FASB and (I)ASC conceptual frameworks ${ }^{25}$ show the trade-offs that exist between these characteristics (this is discussed in chapter 5). One of the hypotheses tested was that the financial accounting framework could also be used in a management accounting context. The only differences would be divergences in the weighting of the distinctive data characteristics. Some 240 inquiry forms were sent out to be filled in by 120 Dutch financial accounting functionaries and 120 Dutch management accounting functionaries and controllers. The results are described in chapter 6 . The useful response was $38 \%$. The respondents generally had to answer on a five-point Likert scale (ranging from most important to unimportant). Finally the answers were tested nonparametrically using the two-sample Kolmogorov-Smirnov test. The standard used for significance was $5 \%$. The main conclusion from this research is that the financial accounting framework, as far as information characteristics are concerned, could also be used in a management accounting context (within a 95\% confidence range). The distinctive data features were not weighted differently in the financial and management accounting contexts. This finding is rather disappointing, because it would be anticipated that relevance and hence timeliness, feed-forward and feed-back value would be significantly more important in a management accounting perspective. But the research data did not support this hypothesis. Obviously the management accountants and controllers were not able to disengage themselves from a certain financial accounting background. The average score for relevance was 4.44 and for reliability 4.27 and hence the relevance/reliability ratio was 1.04 .

This ratio was not significantly different for any specific activity (non-profit, auditing, management, government). ${ }^{26}$ The company's orientation (national/international) was also not decisive for the ratio ( 1.07 vs. 1.03 ). The ratio increased for functionaries who had been executing the function for longer, but the difference was not significant. The average scores for relevance and reliability for the management accountants and controller group were 4.57 and 4.11 respectively. The average scores for these items within the financial accountant group were 4.19 and 4.33 respectively. Looking at the relative frequency, it is noteworthy that $88 \%$ of the accountants' answers for the

\footnotetext{
${ }^{24}$ Of course not all of the net income mutation may be explained by forces. It is a matter of materiality and costbenefit whether the accountant should look for the profit drivers.

25 As far as the information characteristics are concemed.

26 Although the ratio was remarkable high in the non-profit sector, at 1.16.
} 
characteristic 'relevance' fell within the categories 1 and 2 (most and very important). This was $98 \%$ for the controllers. For reliability the figures were $92 \%$ and $74 \%$ respectively. Taking out the management accountants from the accountants cohort, the figures above change remarkably. For the financial accountants (auditors) the relevance/reliability ratio is 0.94 , whereas for the management accountants (including controllers) the ratio was 1.28. Almost none of the respondents indicated that they felt any need to extend the choice of criteria. This means that this set of criteria may properly be used within either a financial accounting or a management accounting context.

In general the differences in weights used for the several aspects were not significant. Several correlation tests (Spearman rank order) were executed to trace the associations between the different choices of aspects and to validate the internal consistency of the answers. These tests justified the confidence given to the research results.

In almost all of the responding companies the financial accounting system and the management accounting system coincided (this was a matter of cost and efficiency). But in more than half of the investigated cases a radical change in the management accounting system was expected within the next three years, i.e. in the area of performance measurement. Almost $80 \%$ of all respondents believed that current management accounting systems were unsatisfactory. Some $20 \%$ of the respondents indicated that the management accounting system should be improved by adding future-oriented data to the system. This is important with reference to triple-entry and momentum accounting. But when implementing such a system the accountant needs to be detached from criteria such as neutrality, verifiability and reliability. In a management accounting context these criteria are not very relevant because the accounts are being prepared for a single user with whom the accountant is in close contact, and there will normally be no conflict of interest between the two about the information to be provided.

To supplement Ijiri's concept of triple-entry and momentum accounting, a general ledger model must be designed to implement the ideas practically (see chapter 8). From a theoretically sound basis, new accounts must be designed to make up the action statement and momentum statement from the general ledger, and new accounting rules have to be designed. Evidently the actual trigger or impulse of any administrative action should not be transactions but (documented) decisions. This could mean that the classical definition of events needs to be modified. But as an event is defined as 'a happening of consequence to an entity' (SFAC 6) this is not necessary. ${ }^{27}$ Applying the concept of income realization correctly, a distinction is made between realized and unrealized income forces (or profit drivers) in such a way that the connection with the traditional accounting system is preserved as much as possible.

27 When for example interest rates increase this is 'a happening of consequence $t o$ an entity'. It is a curious fact that such happenings are not captured within the traditional system. 
Ferrara 57

Flamholtz 16, 76, 119

Fox 1, 25, 57, 65, 166, 167

Francesca 38

Francis 20, 22, 93, 94, 169

Fraser $51,126,127$

Freud 8

Friessen 88

Gailbraith 70

Galilei 28, 51, 142, 145, 147, 149, 150, 151, 154

Geijsbeek 40

Gleick 119, 152

Goethe 43

Goldratt 1, 57, 60, 65, 166, 167

Goletz 60

Gorbatsjov 44

Gordon 81, 88, 89, 97

Govindarajan 68, 87

Groot 69

Gutenberg 36

Hamid 36

Hamilton 41, 153

Hanson 96

Harris 71

Hartman 117

Hartog 3, 61

Have ten $37,38,39,43,44,143$

Hayes 62

Hedberg 31

Heisenberg 27, 152

Hemandez-Esteve 143

Hicks 12

Hiromoto 88

Hirsch 73

Hodge 97

Hofstede 14, 17, 59, 67

Holt 160

Hopper 33, 55, 61

Hopwood 11, 60, 63

Homgren 11, 49, 93, 96

Hoskin 45, 48

Ijiri $1,2,8,9,18,19,28,38,69,83,95,96$, $120,121,122,123,126,127,128,130,131$. $141,142,144,147,148,150,153,154,155$, $156,159,163,169,170,172,181,184,189$, $212,213,215,216,217$

Inoue 41

Iwabuchi 71

I7.cboud 28, 74
Jaedicke 83

Jensen 23, 67

Jevons 150

Johnson 45, 54, 55, 57, 58, 59, 61, 64, $68,69,70,76,77,91$

Jones 80,81

Jong de 119

Jung 8

Kandelin 13, 81, 82

Kaplan 1, 18, 22, 25, 28, 29, 45, 46. $48,49,51,54,55,57,58,59,61,62,64,69$, $70,73,90,91$

Keegan 60

Kelly 44

Kennelly 50

Kepler 144

Khandwalla 88

Kirk 83

Klant 74

Kleijnen 81,82

Knoops 8, 166

Koch 152

Kolmogorov 101, 110, 227

Kozmetsky 44, 75, 216

Kuhn 22, 52

Lagrange 67

Lall Nigam 42

Laplace 152

Larcker 97

Laughlin 33

Lee $64,66,70,74$

Leech 211

Lewy 14

Liempt van 125

Limperg 34

Likert $1(0), 102,104,110$

Lin $13,81,82$

List 58

Lister 43

Litteton 45, 46, 47, 48, 54

Loft 52

Lorenz 152

Lowry 55

Macve 45, 48

Mandelbrot 152

Mann 225

March 51

Markus 60

Marx 11

Mattessich 51. 148 
Maurits 40

McCarthy 213

McGhee 222

McIntyre 221

Meckling 23, 67

Mednick 1, 52, 58, 119

Mepham 211

Merchant 26, 27, 52, 66, 67

Meuwissen 102

Miles 87, 88

Miller 33, 88

Mintzberg 15, 16

Mock 31, 82

Molenkamp 61

Morris 80, 82

Mullins 65

Nakanishi 39

Napoleon 33

Narayanan $81,88,89$

Nath 65,224

Needles 93

Neumann $30,59,80,81$

Newbold 160

Newell 29

Newton 142, 147, 149, 150,151, 152, 154

Nigam 42

Nobes 51

Oldcastle 40

Oonincx 63, 89

Opelland 63

Oresme 145

Otten 61

Ouchi 73

Pacioli 35, 36, 37, 38, 39, 40, 41, 52, 70, 74, $142,143,145,169,170,211,212,216$

Parkinson 1, 38

Pareto 25

Pascal 38,

Pauli 8

Pearson 228

Peters H., 67

Pcters J., 3, 28, 74

Pfeffer 60

Pietersz 40

Pisano 35

Plato 144,151

Poel van de $12,49,61,87,90$

Pope 231

Porter 58, 61, 88, 89, 114

Prakash 20, 27
Puxty 231

Ramanauskas-Marconi 31

Rappaport 20, 27

Reece 8 .

Rendel 8

Roover de 37

Ross 17

Saint-Ferdinand 67

Samuelson 128, 151

Santayana 33

Saxony van 145

Scapens 18, 19, 22, 23

Scholtes 144

Schreuder 23, 34, 45, 60

Schumpeter 43

Schwarz 41

Scorgie $38,40,42$

Senesio 38

Shank 68,87

Siegel 31, 100

Simmonds 68

Simon 29,62

Simons 89

Skelton 168

Smimov 101, 110, 227

Smith 45

Snow 87,88

Snowball 221, 222

Sol 64

Sombart 42, 43

Sorter 13, 212

Spcarman 112, 228

Spicer 44

Sriram 153

Stamp 91

Starreveld 12

Sterling 51

Stevelinck 34

Stevin 40

Stewart 48

Stolowy 211

Sundem 11, 93, 96

Swanbom 221, 223

Swicringa 221, 222

Taylor 37, 39, 47

Teamey $20,22,93,94,169$

Thompson 88

Thomsen 214, 215

Tiessen $14,16,88$

Tijhuis 109 
Tinbergen 143,150

Traas 222

Tuggle 97

\section{Vasari 38}

Vatter 62

Veeken van der 57,64

Vemooij 119, 124

Vinci da 37, 145

Voss 50

Vries de 45

\section{Walgenbach 96}

Walker 34

Wallage 109

Walras 150

Walsch 48

Waterhouse $14,16,88$

Waterman 3, 28

Watson 228

Watts 24

Weber 43,67

Weezenberg 65

Weick 221, 222

Williamson 46

Wilson 51, 79

Winters 160

Wisse 216

Witney 225

Wolcoxon 225

Wolk 20, 22, 93, 94, 169

Worthington 40

Wouters 64

Yamey 38, 39, 40, 41, 43

Ympijn 39, 40

Zimmerman 24

\section{Zakenregister}

accountability 19,31

accounting, mark-to-market 28

accounting, financial $11,47,60,61$

accounting, matrix- 209

accounting, wealth 10,155

accounting, quad 171

accounting, behavioral 65,75

accounting, market value 28

accounting, psychologische aspecten van 66 accounting sandbox 214

accounting, management $1,11,12,19,33$,

$58,61,91,108$

accounting, differential quaddrupple 159

accounting, fair value 29

accounting, multidimensionale 210

accounting, positive 24

accounting, gedragsaspecten van $18,27,31$

accounting, physical 69

accounting, momentum $1,4,8,9,33,69$,

124,127

accounting, inflation 69

accounting, current cost 69

accounting, temporal triple-entry 123,129 .

136,139

accounting, differential triple-entry $2,3,10$,

$123,138,140,142,182$

accounting, triple-entry $1,4,8,10,33,69$,

117,127

accounting, strategic management 68

accounting, sociale aspecten van 66

accounting, cost 48

accountingmodel, twee-dimensionaal 174

accountingmodel, drie-dimensionaal 181

accountingsysteem, relationeel 211

accountingsysteem, intem 114

accountingsysteem, management 12,13

action statement 155, 182, 204

activity based costing 68

administratie, hoeveelheids- 34

administratieve organisatie 229

administreren, ondememend 77

adverse selection 24

afstemmingsprincipe 161

agency costs 24

agency paradigma 25

agency-theorie $21,23,50,67$

agency-theorie, positieve 24

beheersing $12,14,15$

berichtgeving, exteme 29,48 
berichtgeving, interne $11,115,117$

beslissingsondersteuning 12

bestandsorganisatie 217

bestelgrootte, optimale 71

besturing 14

betrouwbaarheid 13,107, 110

boekhouden, Duitse methode 41

boekhouden, Italiaanse methode 37,41

boekhouden, methode van Venetië 37

boekhouden, enkelvoudig of enkel 95, 123

boekhouden, dubbel of tweevoudig 36, 39, 41,

$95,121,123,127$

boekhouden, enkel uitgebreid 169

boekhoudsysteem, Bahi-khata $\mathbf{4 2}$

boekingsdocumenten 168

boekingsregels 125, 130, 187

bonding 23

budgetrekening 131

budgettering 139

causaliteitsprincipe 160

conceptual framework $82,85,99$

constante kosten 74

contagion effect 63

control, management $14,15,50$

control 12, 14, 88

controleerbaanheid 82

cost-analysis, strategic 68

costing, target 71

cycle time 71

decision approach 18

differentiatie 73

dimensie $1,2,4,51$

dimensie, -analyse 119

dimensie, eersie 2

dimensie, tweede 2

dimensie, derde $2,8,120,126,137,184$

dimensie, vierde 158

doelvermogen 133

doorlooptijd 71

downscaling 71

dualiteit 8

earning power $3,4,122,153$

economische gebruiksduur 73

eigen vermogen, samenstelling $1,120,125,189$

eigen vermogen, omvang 1, 121, 125, 189

empowerment, employee 77

entiteits-relatie model 212

entity concept 93

evaluating 17

events approach 13, 212 feedback 14

flexibiliteit 72,76

force $141,147,162$

gebruiksduur, economische 73

gegevens, hiërarchie van 83

gegevens, ex-ante (tockomstgerichte) 47, 54, 75 ,

81,167

gegevens, niêt-financiēle 81,167

gegevenskenmerken 79

getallen, negatief 96,212

groeikracht 141, 150

grootboekrekening, controlerende winst-mutatie

185,203

grootboekrekening, verklarende winst-mutatic

186

grootboekrekeningen, contra 207

Hamilton-mechanisme 153

Heisenberg-principe 152

hiërarchie 74

human information processing 29

impuls, structurele 157

impuls 141,150

impulse statement 4,182

income momentum $4,10,95,122,141,147$.

$149,150,153,182,205$

industriële economie 68

informatie, analyse van 89

informatie, waarde van 30

informatie-assymetrie 24

informatiebeleid 98

informatiesysteem 18

informatiesysteem, management 80

information inductance $7,20,28$

information economics 22,29

innovatie 72

instandhoudingscriterium 160

instandhoudingseis 126

tegratie-eis 48

tegriteitseis 126

Inteme controle 229

investeringsbeoordeling 73

ist-boeking 196

kasstroomoverzicht 166

kostencalculatie, variabele 74

kostenplaatsenmethode 69,71

kritieke succesfactoren $3,73,163$

kwaliteit 72, 73

-wantificeerbaarheid 82 
laboratorium-experiment 221

leereffect 73

Likertschaal 100,102, 104

managing eamings 26

measurement, accounting 92,93

measuring 17

momentum statement $4,148,155,182$

monitoring 23

moral hazard 24

nonparametrische test 100

onpartijdigheid 82

organisatiestructuur 87

oriëntatie 79

overheadkosten 74

postcoobrdinatie 217

posten, nominale 128

posten, reële 128

profit driver 3

rapporteren, ondememend 28

reeksen-theorie, twee-rekeningen 125

reeksen-theorie, drie-rekeningen 132

registratie 45

relatie, principaal-agent 23

relativiteitstheorie 151

relevantie $1,79,82,107,110,224,229$

rendementswaarde 153

requisite variety 89

residual loss 24

resistance to change 59

responsiviteit 76

rewarding 17

scientific management 47

snelheid, gemiddelde 145,148

soll-boeking 196

stroomgrootheden 140

stuurvariabelen 15

systeem 12

systeem, technisch ontwerp 92

systeem, analyse van 89

target-rekening 131

team-produktie 73

theorie Z 73

throughput time 71

trade-offs 85

transactiekosten-theorie 46

transacties 93 transactionele model 215

trebit 131

two-sample Kolmogorov-Smimov test 101, 110

user need approach 212

user-decision-making approach 18

user-need school 13

validiteit, externe 222

value school 13

veldexperiment 221

verantwoordelijkheidsrelatie 13,21

verantwoording 12

verantwoording, inteme 12

verantwoording, exteme 12

vermogensbestanddeel, rekening van 131

vermogensbestanddelen 120,125

vermogensrekening, begrote 131

vermogensrekeningen $121,125,130$

verschillenanalyse 9,72

verslaglegging, inteme 11

verslaglegging 7

versnelling 146

vlindereffect 152

voorraadgrootheden 140

waardenkringloop 213

waardering 45

wealth 128

wealth-income model 216

winst-acceleratievermogen 156

winst-mutatiestaat $2,5,155,182,183,202$

winstcapaciteit 3,148

winstelasticiteit 161,209

winstkracht, ongerealiseerd 187

winstkracht $2,5,10,96,124,130,154,165$

winstkrachten, externe 163

winstkrachten, inteme 163

winstmutatie $3,10,184$

winstsnelheid $5,10,141,149$

winstsnelheids-mutatiestaat $4,5,156,182,204$

winstsnelheids-staat $5,155,182$

zaaktheorie 93 
Additional Disclosure is het resultaat van een dissertatie-onderzoek naar de toepasbaarheid van een driedimensionaal boekhoudsysteem.

Bij triple-entry accounting worden naast omvang en samenstelling van het vermogen ook winstkrachten geadministreerd. Bij een momentum accountingsysteem wordt de winstcapaciteit uitgedrukt als een winstsnelheid.

Uit het onderzoek blijkt dat met behulp van de besproken technieken de kwaliteit van beslissingen aanzienlijk kan toenemen. Gebruikers blijken goed in staat de driedimensionale financiële gegevens in hun besluitvorming te integreren.
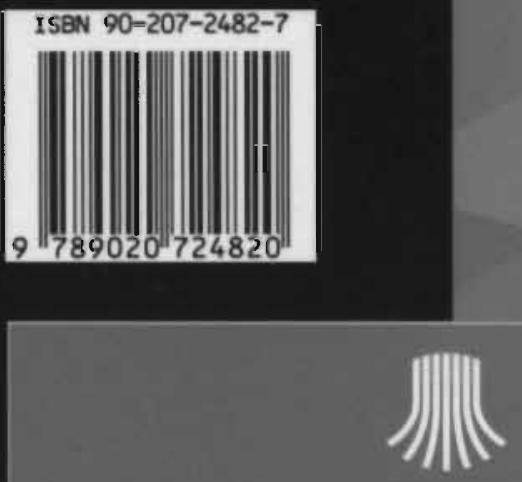